\section{UNIVERSIDAD POLITÉCNICA DE VALENCIA}

DEPARTAMENTO DE INGENIERÍA MECÁNICA Y MATERIALES

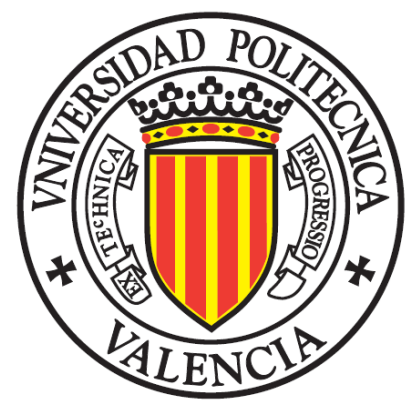

UNIVERSITY OF SOUTH FLORIDA

COLLEGE OF ENGINEERING

DEPARTMENT OF ELECTRICAL ENGINEERING

\title{
Evaluation and Assessment of New Demand Response Products Based on the Use of Flexibility in Industrial Processes: Application to the Food Industry
}

\author{
Dual Ph.D. Program
}

between the Universidad Politécnica de Valencia and the University of South Florida

DOCTORAL DISSERTATION

Author:

Manuel Alcázar Ortega

Co-Major Professors:

Carlos Álvarez Bel, Ph.D.

Alexander Domijan, Ph.D.

Tampa FL (EEUU), February 2011 
Evaluation and Assessment of New Demand Response Products Based on the Use of Flexibility in Industrial Processes: Application to the Food Industry

by

Manuel Alcázar-Ortega

A dissertation submitted in partial fulfillment of the requirements for the degree of Doctor of Philosophy Department of Electrical Engineering College of Engineering University of South Florida

Co-Major Professor: Carlos Álvarez-Bel, Ph.D. Co-Major Professor: Alexander Domijan, Ph.D. Rafael Perez, Ph.D. Wilfrido A. Moreno, Ph.D. Ángel Pérez-Navarro-Gómez, Ph.D. Antonio Gabaldón-Marín, Ph.D. José Roger-Folch, Ph.D.

Date of Approval:

February 4, 2011

Keywords: Demand Side Management, Food Engineering, Load Management, Power Control, Power Demand, Production Management

Copyright @ 2011, Manuel Alcázar-Ortega 


\section{ACKNOWLEDGEMENTS}

First and foremost, I would like to thank my major professors, Dr. Carlos Alvarez Bel and Dr. Alexander Domijan, for their guidance, encouragement and their substantial contribution to the completion of this work. Most especially, I would like to express my gratitude to them for giving me the opportunity to develop this dissertation in the framework of the Dual Program between the UPV and USF.

My most sincere thanks also go to my committee members, Dr. Antonio Gabaldon, Dr. Jose Roger, Dr. Rafael Perez, Dr. Wilfrido Moreno and Dr. Angel PerezNavarro for their support, feedback and suggestions, and to Dr. Thomas Crisman for chairing my defense.

Likewise, I wish to gratefully acknowledge the contribution of the company Campofrio Food Group, S.A., for providing me with the appropriate framework to test the techniques developed in this dissertation, and especially to the facility manager at the Torrijos factory Ignacio Alvarez, as well as to the technical staff of the enterprise Demanda Activa de Energia for their assistance.

Thanks also to my colleagues from the Institute for Energy Engineering, particularly to Guillermo Escrivá and Carla Montagud, for their valuable comments and assistance. The language editing services of Meggan Harris are also gratefully acknowledged

Finally, I would like to thank my family and friends for their support and confidence. 


\section{TABLE OF CONTENTS}

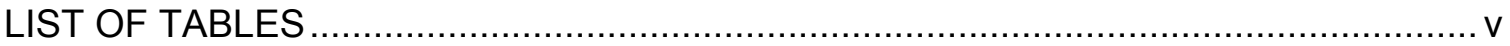

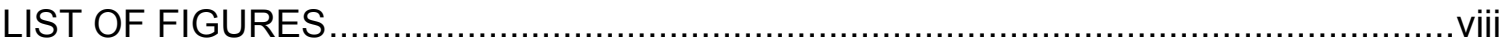

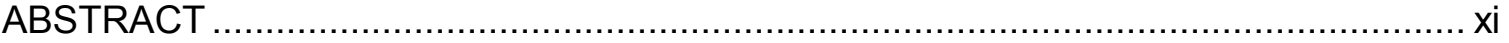

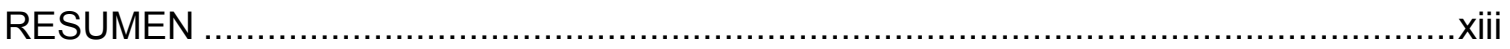

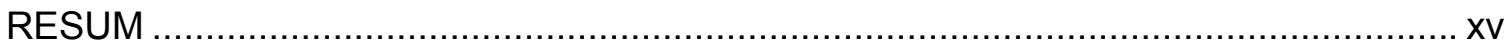

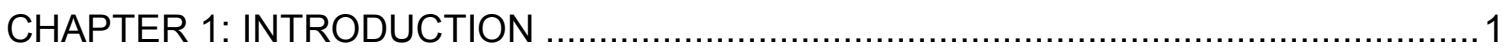

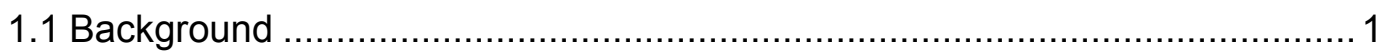

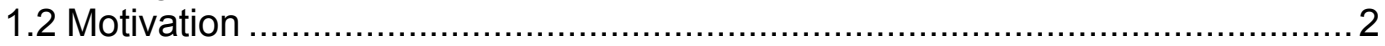

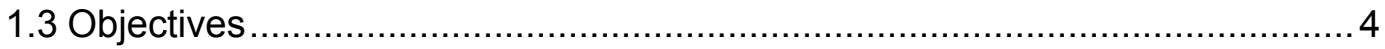

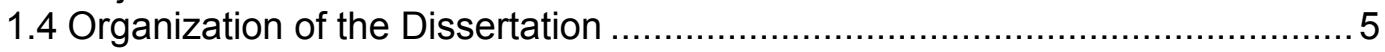

CHAPTER 2: STATE OF THE ART: DEMAND RESPONSE IN THE UNITED

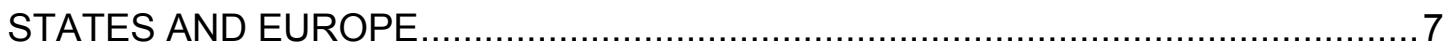

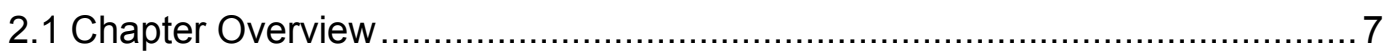

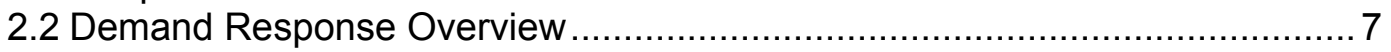

2.3 Classification of Demand Response Actions .............................................. 9

2.4 Classification of Demand Response Programs ........................................ 10

2.4.1 Operation Programs ............................................................ 12

2.4.2 Economic Based Programs .................................................... 14

2.5 Demand Response in the United States .................................................. 15

2.5.1 Operation and Market Organization in the United States of

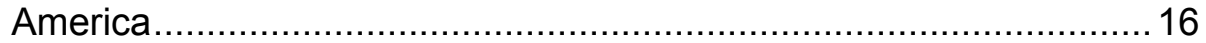

2.5.2 DR Programs Offered by System Operators.............................. 20

2.5.2.1 New York ISO ..................................................... 20

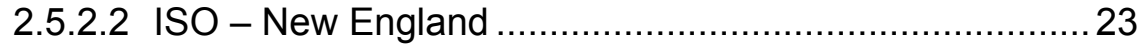

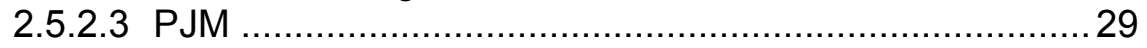

2.5.2.4 Electric Reliability Council of Texas............................... 31

2.5.2.5 Southwest Power Pool............................................. 36

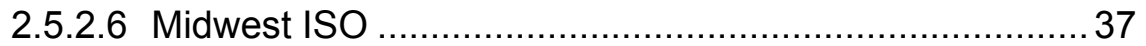

2.5.2.7 California ISO ...................................................... 41

2.5.3 DR Programs Offered by Utilities ............................................ 43

2.5.3.1 Arizona ................................................................... 45

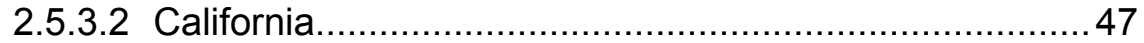


2.5.3.3 Connecticut............................................................. 53

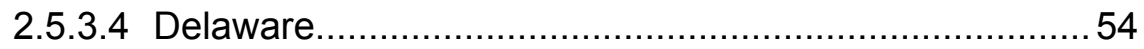

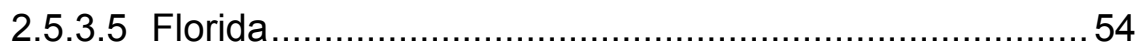

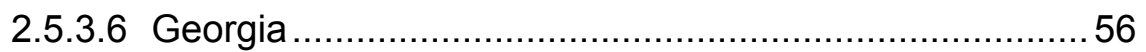

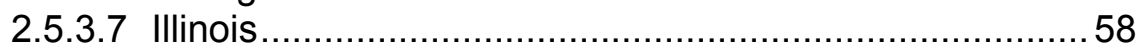

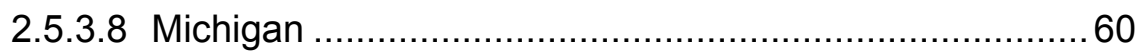

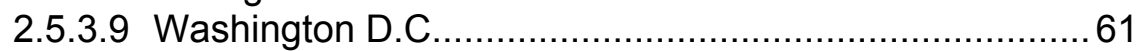

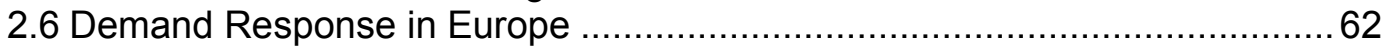

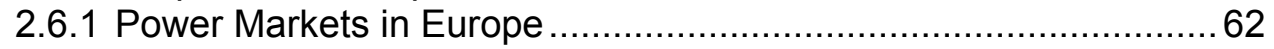

2.6.2 Demand Response Programs in Europe.......................................64

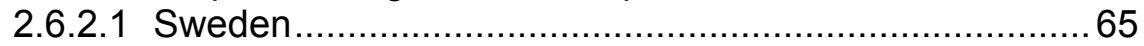

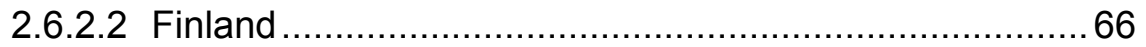

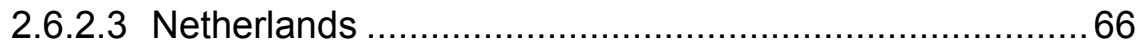

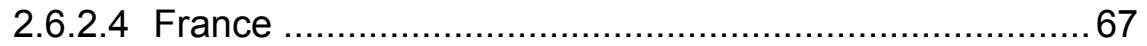

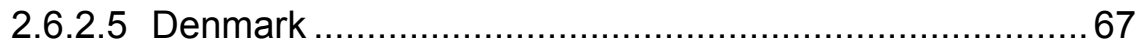

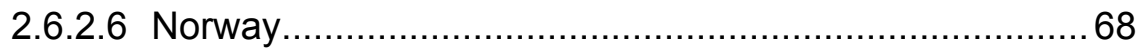

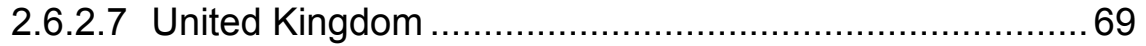

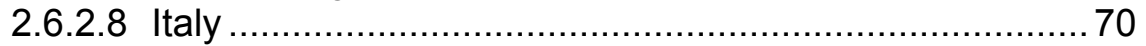

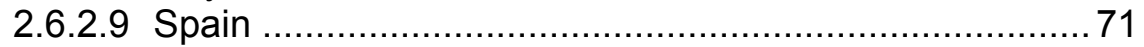

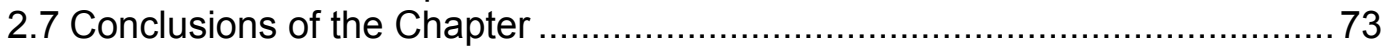

CHAPTER 3: METHODOLOGY TO DEFINE NEW DEMAND RESPONSE PROGRAMS BASED ON CUSTOMER FLEXIBILITY: CUSTOMER

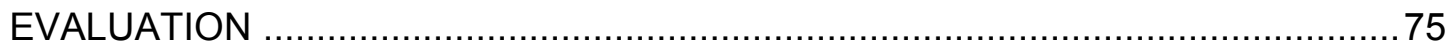

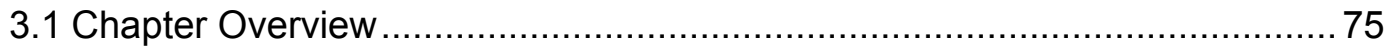

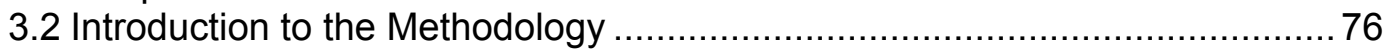

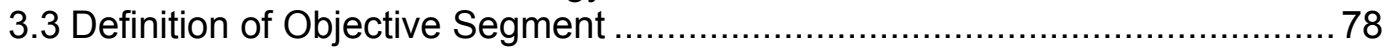

3.4 Characterization of Processes by End-Use ............................................. 81

3.4.1 Detailed Analysis of the Load Curve ………………................... 84

3.4.2 Physical Modeling ……........................................................... 86

3.4.2.1 FLEXMOD: the UPV Modeling Tool ……………........... 89

3.5 Determination of Possible Flexibility Actions ………................................. 91

3.5.1 Classification of Flexibility Actions ............................................. 92

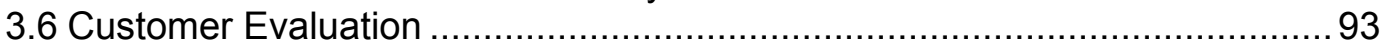

3.6.1 Technical Evaluation ........................................................... 94

3.6.1.1 Technical Evaluation of Flexibility in Flat Shape Processes ................................................................. 97

3.6.1.2 Technical Evaluation in Non-Flat Shape Processes ......................................................................

3.6.2 Economic and Environmental Evaluation....................................99

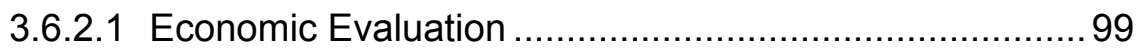

3.6.2.2 Environmental Evaluation ........................................ 104

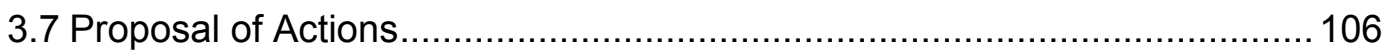

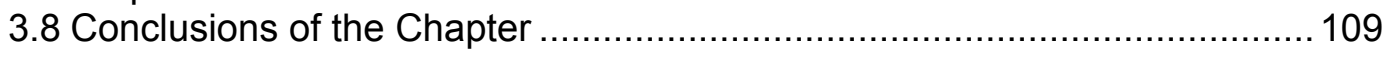

CHAPTER 4: METHODOLOGY TO DEFINE NEW DEMAND RESPONSE PROGRAMS BASED ON CUSTOMER FLEXIBILITY: REGULATORY

ASSESSMENT.

4.1 Chapter Overview........................................................................ 110

4.2 Integration of Flexibility in Operation Markets ………............................. 110 
4.2.1 Technical Assessment ..................................................... 110

4.2.1.1 Operation Markets in Power Systems ........................ 111

4.2.1.2 Customers Providing Operation Services.................... 113

4.2.2 Economic Assessment ........................................................ 120

4.2.2.1 Avoided Costs Analysis ..................................... 121

4.3 Definition of Demand Response Programs .......................................... 125

4.3.1 DR Programs for Operation Markets....................................... 125

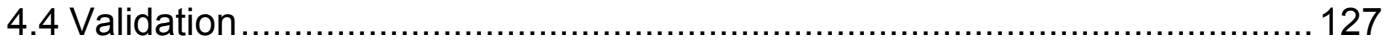

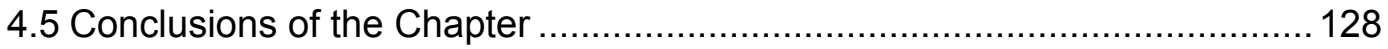

\section{CHAPTER 5: FLEXIBILITY AND EFFICIENCY ACTIONS IN THE FOOD}

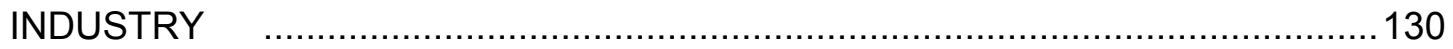

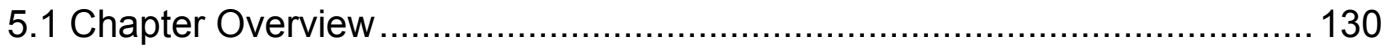

5.2 The Use of Energy in the Food Industry ............................................... 130

5.2.1 Flexibility Strategies in the Food Industry............................... 133

5.2.2 Significant Activities in the Food Industry............................... 135

5.2.2.1 Preparation ......................................................... 136

5.2.2.2 Transformation.................................................... 139

5.2.2.3 Preservation......................................................... 140

5.2.2.4 Packaging ......................................................... 142

5.3 Application of the Methodology to the Meat Industry................................ 142

5.3.1 The Role of the Meat Industry Worldwide ............................... 142

5.3.2 Flexible Processes in the Meat Industry................................. 144

5.3.3 Description of the Drying Process ......................................... 145

5.3.3.1 Type of Drying Rooms ......................................... 145

5.3.3.2 Stages in the Drying Process ................................. 146

5.3.3.3 Psychrometric Analysis........................................... 148

5.3.4 First Strategy: Interruption of Cooling Production and

Distribution in Drying Rooms ..................................................... 150

5.3.4.1 Use of Cooling in the Meat Industry........................... 150

5.3.4.2 Implementation of the Flexibility Action ....................... 154

5.3.5 Second Strategy: Fan Speed Variation in Drying Chambers ....... 155

5.3.5.1 Modeling ............................................................... 156

5.3.5.2 Theoretical Evaluation of the Strategy........................ 158

5.3.5.3 Implementation of the Flexibility Action ....................... 160

5.4 Conclusions of the Chapter .............................................................. 163

CHAPTER 6: VALIDATION TESTS IN A CURED HAM FACTORY IN SPAIN:
TECHNICAL EVALUATION $6 \ldots \ldots \ldots \ldots$
6.1 Chapter Overview
6.2 Validation of First Strategy
6.2 .1 Pre-Evaluation
6.2 .2 Campaign of Interruptions
6.3.1 Description of Considered Drying Chambers
6.3.2 Psychrometric Analysis of Drying Chambers
6.3 .3 Evaluation of Reduced Speed 


\section{CHAPTER 7: ECONOMIC AND ENVIRONMENTAL EVALUATION OF}

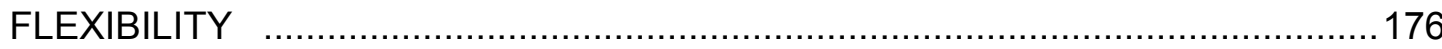

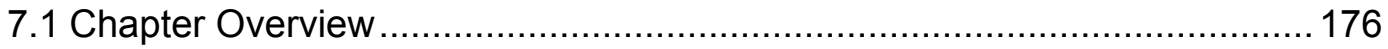

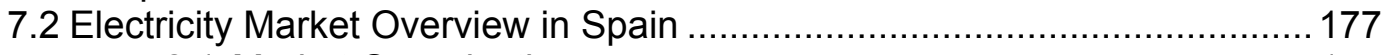

7.2.1 Market Organization ......................................................... 177

7.2.2 How Do Customers Pay for Electricity in Spain? ....................... 178

7.2.2.1 Components of the Electricity Bill ............................. 179

7.2.2.2 Hourly Periods of the Contract.................................. 179

7.2.3 Operation Markets in Spain.................................................. 182

7.3 Economic Evaluation of Flexibility in the Meat Industry............................ 184

7.3.1 Cost-Benefit Analysis for the Customer .................................. 184

7.3.1.1 Flexibility Costs Evaluation ..................................... 185

7.3.1.2 Participation in Operation Markets Simulation............. 186

7.3.2 Extrapolation of Results to the Whole Segment........................ 193

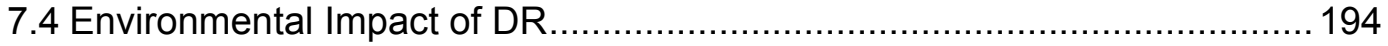

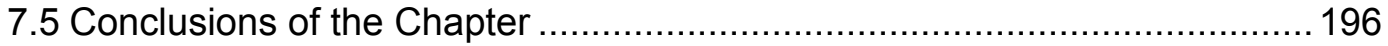

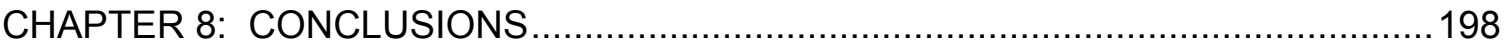

8.1 Conclusions and Contributions of the Dissertation ................................. 198

8.1.1 Needs Identification: Underutilization of DRR and Requirement of New Tools

8.1.2 Development of a New Methodology: Technical and Economic

8.1.3 Validation of the Methodology: Application to the Food Industry

8.1.4 Use of Flexibility: Simulation of Customers Participation in Operation Markets in Spain ...................................................... 200

8.1.5 Impact on the System: Extrapolation of Results to the Meat Industry Segment in Spain.................................................... 201

8.2 Future Research.

LIST OF REFERENCES

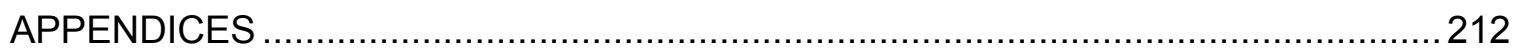

Appendix A: Abbreviations ........................................................... 213

ABOUT THE AUTHOR End Page 


\section{LIST OF TABLES}

Table 1. System operators in the United States of America...................................... 17

Table 2. Main characteristics of electricity markets in the U.S................................19

Table 3. Summary of the DR programs offered by the New York ISO .........................23

Table 4. Summary of the DR programs offered by the ISO - New England ..................28

Table 5. Summary of the DR programs offered by the PJM Interconnection..................31

Table 6. Summary of the DR programs offered by the Electric Reliability Council of Texas

Table 7. Summary of the DR programs offered by the Southwest Power Pool 37

Table 8. Summary of the DR programs offered by the Midwest ISO 40

Table 9. Summary of the DR programs offered by the California ISO .42

Table 10. Ranking of the most suitable industrial segments for DR. .80

Table 11. Emission factors for different sources of energy and countries 105

Table 12. Emission factors for different periods in Spain 105

Table 13. Example of identification parameters card on customer flexibility 108

Table 14. Technical aspects of primary frequency regulation service. 116

Table 15. Technical aspects of secondary frequency regulation service 117

Table 16. Technical aspects of voltage control service 118 
Table 17. Bonus coefficients for special regime generators in Spain

Table 18. Technical aspects of restoration by means of blackstart capability service.

Table 19. Cost of generating electricity for different technologies in the U.K.

Table 20. U.S. average levelized costs (in $\phi$ of US $\$$ and $€$ ) for plants entering service in 2016

Table 21. Classification of the different food production activities. 131

Table 22. Classification of main processes in the food industry. 132

Table 23. Meat production around the world (2005), in thousands of tons 143

Table 24. Consumption of electricity ( $\%$ of total) in three different cured meat factories in Spain

Table 25. Breakdown of electricity consumption in different cured meat production factories.

Table 26. Identification parameters card of customer flexibility for strategy 1. 154

Table 27. Ratios of speed, consumption and power increment in drying chambers .....161

Table 28. Identification parameters card of customer flexibility for strategy $2 \ldots \ldots \ldots \ldots \ldots . . . .162$

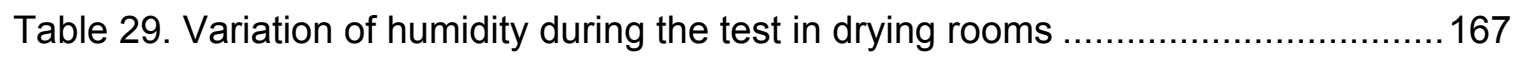

Table 30. Variation of temperature during the test in drying rooms ........................... 167

Table 31. Set point parameters for different drying chambers in a cured-ham factory .....

Table 32. Characteristic points in the psychrometric chart for the different chambers

Table 33. Factor and correlation coefficient of the power equation

Table 34. Ratios of speed, power and time after applying the proposed actions. 173

Table 35. Definition of periods for peak-shoulder-valley contracts in Spain. 180 
Table 36. Definition of periods in seasonal contracts in Spain

Table 37. Costs of flexibility for a customer in the meat industry ............................ 186

Table 38. Inputs for the IEA task XIII tool - segment of meat products ....................... 194

Table 39. Emission factors for a six-period contract in Spain ................................ 195

Table 40. Avoided emissions into the atmosphere for one customer.......................... 196 


\section{LIST OF FIGURES}

Figure 1. Different types of demand response actions ........................................... 9

Figure 2. Classification of demand response programs .........................................11

Figure 3. Number of entities offering DR and coincidental peak load reduction .............15

Figure 4. Map of system operators in the U.S............................................... 18

Figure 5. Map of the electricity markets in the U.S.......................................... 18

Figure 6. Electric utility demand-side management programs in the U.S.

(1989-2007)

Figure 7. Savings obtained through electric utility DR programs in the U.S.

(1989-2007)

Figure 8. Map of studied states where DR programs have been developed by utilities

Figure 9. Regional power markets in Europe

Figure 10. Demand response forecast in UCTE countries from 2008 to 2020. 65

Figure 11. Methodology for developing DR programs based on customer profiling .......77

Figure 12. Segmentation methodology developed by IIE-UPV ..................................79

Figure 13. Production of ceramic tiles: demand characterization by end-uses .............. 82

Figure 14. Production of ceramic tiles: load curves on different types of days ..............83

Figure 15. Identification of typical days in a commercial customer ............................. 85

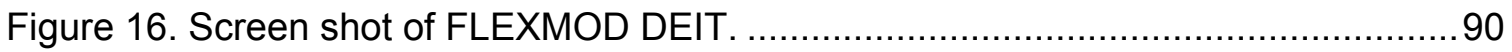


Figure 17. Theoretical model for technical evaluation of flexibility (flat shape) 94

Figure 18. Example of a flexibility application on a non-flat shape customer................96

Figure 19. Economic evaluation of flexibility: cost-benefit analysis for customers ........ 103

Figure 20. Example of a flexibility application by superposition .............................107

Figure 21. Classification of operation markets in power systems ............................112

Figure 22. U.S. average levelized cost for plants commencing service in $2016 \ldots \ldots \ldots . . .123$

Figure 23. Use of energy in the food industry in Canada, 2007 .............................143

Figure 24. Drying processes in a typical cured ham factory ................................ 147

Figure 25. Meat drying process scheme ................................................... 148

Figure 26. Psychrometric chart for a drying room .......................................... 149

Figure 27. Scheme of processes in a typical cured meat products factory .................151

Figure 28. Typical load curve for a cured meat factory ..................................... 153

Figure 29. Effect of interrupting the cooling process in a typical cured meat factory 155

Figure 30. Effect of reducing fan speed in drying chambers at a cured meat factory 162

Figure 31. Pre-evaluation test performed in a cured ham factory ........................... 166

Figure 32. Load curves obtained during the campaign of interruptions .....................168

Figure 33. Relationship between the speed and the power required by fans ..............172

Figure 34. Participation of customers in the MIBEL electricity market .......................178

Figure 35. Prices in the Spanish balancing market from November '09 to November ' 10 .

Figure 36. Participation hours in balancing markets 188 
Figure 37. Monthly results of customer participation in the Spanish balancing market

Figure 38. Prices in the Spanish secondary regulation market (availability) 190

Figure 39. Prices in the Spanish secondary regulation market (delivery) 191

Figure 40. Participation hours in secondary regulation 192

Figure 41. Monthly results of customer participation in the secondary regulation market 193 


\begin{abstract}
In the context of an increasingly competitive electricity market, where prices are constantly rising and the presence of renewable energy resources is gaining prominence, this dissertation deals with an innovative approach to the participation of demand resources in operation markets, paying special attention to energy intensive industrial segments such as the food industry.

The study begins by examining the current status of Demand Response Programs available in different countries. This analysis suggests that customers have been somewhat neglected in the design phase of existing DR programs, and this has resulted in the underutilization and sub-optimal development of demand resources. Furthermore, customers are unaware of the utility that their potential flexibility could be to the electricity grid and do not know how much different actors would be willing to pay them for reducing demand in specific periods.

As a result of this analysis, an innovative methodology is developed to explore and assess new demand response mechanisms in which customers, grid operators and other stakeholder perspectives are considered. This methodology, based on the evaluation and detailed analysis of customer processes, provides customers with suitable tools to evaluate their ability to react to electricity prices. Consequently, the regulator is able to enhance the social benefit, allowing customer flexibility in operation markets and helping to refine the required programs to adequately capitalize on the potential identified by the customer.
\end{abstract}


The methodology developed in this dissertation was successfully applied to the meat industry market segment, and different factories within this segment were studied in detail. In particular, the effectiveness of the proposed actions was successfully tested and validated in an active factory that produces cured ham in Spain, and different flexibility strategies were evaluated.

Finally, an economic evaluation on the profitability of the proposed flexibility actions for both the customer and the power system is discussed. Current prices of operation markets in Spain are considered, even if customers are not actually allowed to participate in such markets at the moment.

The research presented in this dissertation is based on joint work in collaboration with medium and large commercial and industrial customers as well as utilities and grid operators both in Europe and the U.S. The objective of this investigation is to foster the convergence of private interests through the development of enhanced Demand Response design which is better adapted to market participants. 


\section{RESUMEN}

En el marco de un mercado de la electricidad con precios cada vez más altos y donde la participación de fuentes renovables de generación está jugando un papel cada vez más importante, esta tesis supone un enfoque innovador hacia la participación de recursos de demanda en mercados de operación, prestando una atención especial a segmentos industriales como el sector alimentario con un consumo energético intensivo.

En primer lugar, esta tesis describe detalladamente la situación actual de los programas de respuesta de la demanda que existen en diferentes partes del mundo. Este estudio permite concluir que los consumidores no han sido tenidos en cuenta suficientemente en la fase de diseño de los programas existentes, lo que ha provocado la infrautilización de recursos de demanda que, actualmente, permanecen sin explorar. Por otro lado, los consumidores no son conscientes del valor que su flexibilidad podría tener para el sistema eléctrico en su conjunto, ignorando que puedan existir otros agentes dispuestos a pagarles a cambio de reducir sus cargas en períodos determinados. Como resultado, esta tesis desarrolla una nueva metodología para explorar y valorar nuevos mecanismos de respuesta de la demanda donde el punto de vista de consumidores, operadores de red y cualquier otro agente interesado pueda ser tenido en cuenta. Esta metodología, basada en la evaluación y análisis detallado de los procesos, proporciona a los consumidores las herramientas adecuadas para evaluar su capacidad para reaccionar al precio de la electricidad, lo que permitiría al regulador poner en valor el beneficio social de dicha flexibilidad si pudiera ser utilizada en 
mercados de operación, ayudándole a definir los programas necesarios para utilizar de forma adecuada el potencial identificado por los consumidores.

La metodología desarrollada en esta tesis ha sido aplicada satisfactoriamente al sub-segmento de la industria cárnica, por lo que varias fábricas pertenecientes a este segmento han sido estudiadas en detalle. En concreto, la factibilidad de las acciones propuestas ha sido probada y validada satisfactoriamente en una fábrica dedicada a la producción de jamón curado en España, en la que se han evaluado diferentes estrategias de flexibilidad.

Finalmente, se ha realizado una evaluación económica de la rentabilidad de la aplicación de las acciones de flexibilidad propuestas tanto para el consumidor como para el sistema eléctrico en su conjunto, donde se han considerado los precios reales de los mercados de operación en España, aun cuando los consumidores no puedan participar realmente en dichos mercados en la actualidad.

La investigación que se presenta en esta tesis se basa en un trabajo exhaustivo cuya realización ha sido posible gracias a la colaboración con medianos y grandes consumidores comerciales e industriales, así como con compañías eléctricas y operadores de red en Europa y Estados Unidos, con el objetivo de ayudar a la convergencia de los intereses particulares de cada uno de estos agentes, resultando en una metodología para diseñar mecanismos de respuesta de la demanda mejor adaptados a los objetivos de los participantes del mercado. 


\section{RESUM}

En el marc d'un mercat de l'electricitat amb preus cada vegada més alts i on la participació de fonts renovables de generació està jugant un paper cada vegada més important, aquesta tesi suposa una visió innovadora cap a la participació de recursos de demanda en mercats d'operació, prestant una atenció especial a segments industrials com el sector alimentari amb un consum energètic intensiu.

En primer lloc, aquesta tesi descriu detalladament la situació actual dels programes de resposta de la demanda que hi ha en diferents parts del món. Aquest estudi permet concloure que els consumidors no s'han tingut suficientment en compte en la fase de disseny dels programes existents, cosa que ha provocat la infrautilització de recursos de demanda que, actualment, romanen sense explorar. D'altra banda, els consumidors no són conscients del valor que la seva flexibilitat podria tenir per al sistema elèctric en el seu conjunt, ignorant que hi pugui haver altres agents disposats a retribuir-los a canvi de reduir les seves càrregues en períodes determinats. Com a resultat, aquesta tesi desenvolupa una nova metodologia per explorar i valorar nous mecanismes de resposta de la demanda on el punts de vista de consumidors, operadors de xarxa i qualsevol altre agent interessat pugui ser tingut en compte. Aquesta metodologia, basada en l'avaluació i anàlisi detallada dels processos, proporciona als consumidors les eines adequades per avaluar la seva capacitat per reaccionar al preu de l'electricitat, la qual cosa permetria al regulador posar en valor el benefici social d'aquesta flexibilitat si pogués ser utilitzada en mercats d'operació, 
ajudant-lo a definir els programes necessaris per utilitzar de forma adequada el potencial identificat per als consumidors.

La metodologia desenvolupada en aquesta tesi ha estat aplicada satisfactòriament al segment de la indústria càrnia, de manera que diverses fàbriques pertanyents a aquest segment industrial han estat estudiades en detall. En concret, la factibilitat de les accions proposades ha estat provada i validada satisfactòriament en una fàbrica dedicada a la producció de pernil curat a Espanya, en la qual s'han avaluat diferents estratègies de flexibilitat.

Finalment, s'ha realitzat una avaluació econòmica de la rendibilitat de l'aplicació de les accions de flexibilitat propostes tant per al consumidor com per al sistema elèctric en el seu conjunt, on s'han considerat els preus reals dels mercats d'operació a Espanya, tot i que els consumidors no puguin participar realment en aquests mercats en l'actualitat.

La recerca que es presenta en aquesta tesi es basa en un treball exhaustiu, la realització de la qual ha estat possible gràcies a la col·laboració de mitjans i grans consumidors comercials i industrials, així com amb companyies elèctriques i operadors de xarxa a Europa i als Estats Units, amb l'objectiu d'ajudar a la convergència dels interessos particulars de cada un d'aquests agents, resultant així, una nova metodologia per dissenyar mecanismes de resposta de la demanda millor adaptats als objectius dels participants del mercat. 


\section{CHAPTER 1: \\ INTRODUCTION}

\subsection{Background}

The gradual increase in the consumption of energy resources, together with heightened competition in electricity markets, have led to a rise in demand response programs. These are being designed and implemented by energy suppliers and network operators, providing a profitable option for customers that reduce their consumption while simultaneously contributing to system efficiency. At the same time, demand response resources (DRR) represent an adequate option for reserve capacity in the context of increasing wind power generation and usage, which is characterized by its variability and unpredictability [1].

Demand Response (DR) has proven to be a useful mechanism that produces important benefits for both the customer and the power system. However, customers do not usually realize their potential to contribute to system operation through enhanced management of their facilities, which can be accomplished by means of rescheduling production or by reducing the consumption load.

Experience with Demand Response varies by country and market environment. Industrial customers seem very well suited to participate in DR markets since, for practical reasons, small and residential consumers can only participate when managed by aggregators [2]. Large industries such as metal and steel factories, the papermaking industry or the vehicle manufacturing industry have traditionally been willing to reduce part of their energy consumption in exchange for rebates in the monthly electricity bill. 
On the contrary, other electricity-intensive industrial consumers, such as the food industry, have not participated in such programs due to misgivings about potential risks in the degradation of the production processes [3]. Nevertheless, it is worth highlighting that this is one of the industrial sectors which consumes the most electricity [4], with great potential for demand response implementation [5], [6].

\subsection{Motivation}

Different experiences observed by other researchers demonstrate that the active participation of the customer in energy and operation markets can help to improve the performance of electricity systems. However, no examples of previous research were found that described how to determine potential customer flexibility in order to take advantage of different prices of electricity throughout time. This is especially true when such actions are applied to sensitive processes directly related to the quality of the final product, which tend to make customers wary of changing any element or parameter of those processes.

Because of the gradual rise in energy prices, increased concern in environmental issues and the evolution in technological solutions, these rigid industrial practices are being questioned. New actions oriented towards improving energy consumption, like the ones proposed in this dissertation, are being gradually introduced. Moreover, modern information and communication technologies are providing customers with the capability of implementing automatic control devices [7], [8]. This fact makes information more accessible, since electricity prices and similar data can be automatically transferred to customers that may react to such signals.

Demand Response programs are designed by energy suppliers (utilities, retailers, etc.) and system operators (Transmission and Distribution) which do not usually have accurate information about how customers may react to prices and manage 
their facilities. Furthermore, customers are unaware of the utility that their potential flexibility could be to the electricity grid and do not know how much different actors would be willing to pay them for reducing demand in specific periods.

The research presented in this dissertation is based on joint work in collaboration with medium and large commercial and industrial customers as well as utilities and grid operators in both Europe and the U.S. The objective of this investigation is to foster the convergence of private interests through the development of enhanced Demand Response design better adapted to market participants.

The research described in the present document has been carried out in collaboration with the Power Group, within the Institute for Energy Engineering of the Polytechnic University of Valencia (UPV), and with the Power Center for Utility Explorations (PCUE) of the University of South Florida. These groups have extensive experience in the Price Demand Response field, gained in noteworthy research collaboration projects in Europe and the USA, including:

- "DROP" (Demand Response Opportunity Pilot) in collaboration with Progress Energy of Florida;

- "Advanced Commercial Energy" with the Tampa Electric Company;

- "Smart Customer", focused on energy management for the Florida Governor's Offices in St. Petersburg;

- Projects with Red Eléctrica de España (REE, the Spanish TSO), with whom the group has collaborated in many research projects focused on increasing participation of the demand side in the Spanish market; and

- EU-DEEP project (the initiation of a European Distributed Energy Partnership) of the 6th Framework Program of the European Union [5], 
aimed at developing new business models based on market requirements in order to foster development of distributed energy resources in Europe.

The present dissertation builds on this valuable work, focusing on achieving better management of electricity resources and systems.

\subsection{Objectives}

Although active customer participation is essential for the proper development of electricity systems [9], this has rarely occurred. Thus, the underlying aim of this dissertation is to make some progress in this area. Specifically, the present PhD thesis focuses on the development of an innovative methodology to design and assess demand response programs that allow industrial and commercial customers to actively participate in electricity markets. The objectives are as follows:

- To provide an innovative approach to customer flexibility evaluation through a detailed analysis of customers' Demand Response potential based on processes. This "processes approach" analyzes the impact that proposed DR actions may have on each individual energy consuming process throughout the course of production. Instead of simply assessing the impact that a given DR action could have on the total energy demand of the customer, we superpose the effect that different DR actions have on every process, contributing in this way to filling gaps in consumer knowledge of load management.

- To provide customers with the required tools to enhance their knowledge on the need to properly manage their facilities in order to both reduce their electricity bill and to contribute to enhanced operation of the electricity system. Because demand participation in electricity markets 
does not happen spontaneously [2], new tools are required for its evaluation.

- To consider both the customer and the system operator points of view in order to contribute to the proper development of new DR programs. Currently, interaction among them is virtually non-existent; customers are unaware of the usefulness of their flexibility, while operators have little information about how customers are able to manage their facilities.

- To assess the economic impact that DR programs could potentially have on system operation, indexed to the retribution that customers may receive in exchange for their participation.

\subsection{Organization of the Dissertation}

This dissertation is divided into eight chapters, which structure the work in order to achieve the above objectives.

Chapter 2 presents the background of demand response issues around the world, including a complete summary of the main demand response programs existing in both the U.S. and the European Union (EU), whether these are offered by utilities or system operators.

The two following chapters describe the general methodology proposed in this dissertation, which assesses DR potential among customers who participate in operation markets. The rules for developing DR programs according to the value that such potential may have for the operation of power systems is also evaluated. Chapter 3 is focused on the evaluation of customer flexibility while the system operation point of view is detailed in Chapter 4.

Tools to assess technical and economic DR potential are specific to each sector, so this methodology is applied to the particular case of the food industry in subsequent 
chapters. Technical issues associated with the DR in this segment are discussed in Chapter 5, and the proposed methodology is assessed and validated in Chapter 6 . This section details actions (included in the dissertation) which were successfully tested in a range of independent facilities in the meat industry in Spain in order to verify the effectiveness of proposed actions.

Once DR potential is completely evaluated, Chapter 7 deals with the economic and environmental evaluation. A set of DR actions is proposed to assign a value to customer flexibility depending on the usefulness that it could have for a system operator. This analysis includes a procedure to evaluate the payments due to customers according to the value that their actions may have in operation markets, as well as the economic benefit that they could yield to the system.

Finally, Chapter 8 details the most relevant conclusions of the present study, including a summary of the main contributions and an outline of possible areas for future research. 


\section{CHAPTER 2:}

\section{STATE OF THE ART: DEMAND RESPONSE IN THE UNITED STATES AND EUROPE}

\subsection{Chapter Overview}

This chapter provides an outline of the central concepts in the Demand Response field, as well as the current status of Demand Response Programs available in different countries. An introduction on how customers are able to modify their load is presented, including a classification of DR programs that could be used by customers according to the utility that they may have for the system.

A complete revision of demand response programs existing in both the U.S. and in EU countries follows, whether these are offered by utilities or systems operators. Technical and economic issues are analyzed in order to get a general view of how customers are currently participating in electricity markets, what type of actions they are being asked to perform and how much they are receiving in exchange for their participation.

\subsection{Demand Response Overview}

As a consequence of the gradual increase in electricity demand observed over the last several years, together with the massive implementation of renewable resource energy sources, different studies on the expected growth of electricity consumption in Europe have been developed. Some indicate growth rate increases of about $1.4 \%$ per year [10]. Some countries have seen even sharper increases, such as Spain, where 
demand rose $4.0 \%$ in 2006 and $4.2 \%$ in 2007 with respect to the previous year, without considering the influence of labor and temperature [11].

The general economic recession during the last two years has resulted in an unusual situation; electricity demand has decreased and, leading to a reduction of electricity prices ${ }^{1}$ and investment [12]. In spite of that fact, the introduction of new renewable energy resources, especially wind power, has risen dramatically [13]. As a result, there has been a notable increment in the variability and unpredictability of power generation, along with the subsequent rise in the cost of grid management and increased probability of contingencies.

Customers could participate in the solution of these problems by implementing different Demand Response actions. The concept of DR is understood as the ability of consumers to modify the power demand from their expected consumption either as a response to a requirement from the grid operator, load-serving entity (LSE) ${ }^{2}$ or other demand response provider when a reliability problem occurs in the system, or as a reaction to variations in the price of electricity. While DR actions can take place at any time, not only during the peak period [14], their implementation could be key during peak periods of electricity use, and are usually less costly than building more power plants [15].

1 Electricity prices have fallen by half in the U.S. in the last two years due to lower electricity demand and lower fuel costs, as shown in Table 2. As indicated by the Federal Energy Regulatory Commission in its last Annual Report [19], the average electricity price in 2009 was the lowest since the markets began in their current form in the New York ISO and ISO-New England.

${ }^{2}$ Load-serving entity (LSE) collectively refers to utilities and competitive retail suppliers [20] 


\subsection{Classification of Demand Response Actions}

Figure 1 divides DR actions into three blocks [16], [17]:

- Demand reductions during on-peak periods, which are not compensated by rises during the rest of the time.

- Demand shifting to off-peak periods, by moving some energy packages from on-peak periods to shoulder or valley periods, when electricity is cheaper and the operation of the grid is less critical.

- Autonomous generation ${ }^{3}$, producing the electricity that customers use onsite, which translates to a net reduction of the demanded power from the grid with no load modifications required from the consumer.
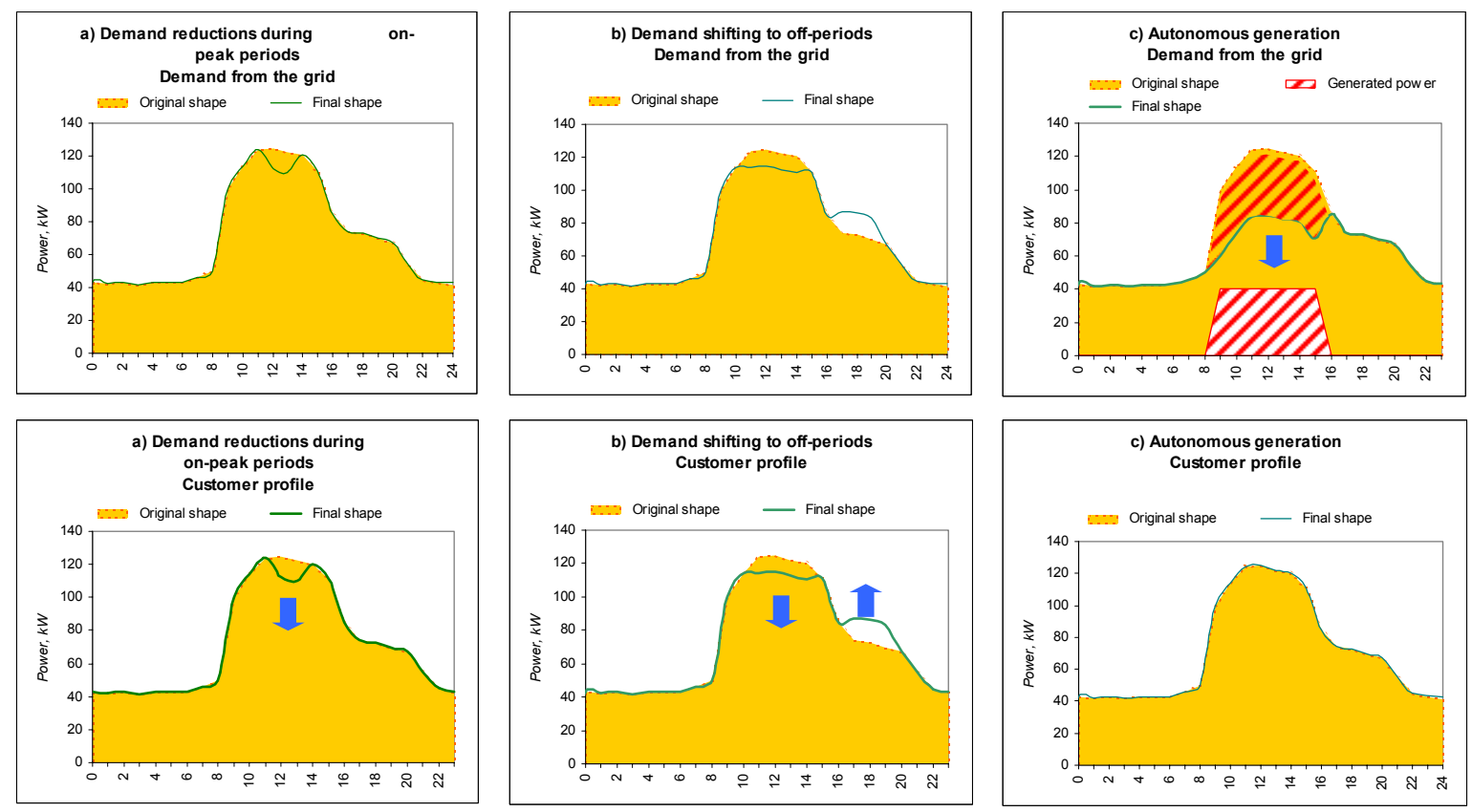

Figure 1. Different types of demand response actions

The figure shows the effect of the different types of demand response actions on both the customer's load curve and the power demanded from the grid. In cases a) and b), a modification of the customer load shape produces the same effect in the power demanded from the grid. On the contrary, in case c), the customer does not modify its demand requirements, but the power demanded from the grid is reduced, since the customer produces part of its own required energy, freeing grid capacity.

\footnotetext{
${ }^{3}$ Also called in bibliography "Behind-the-Meter" (BTM) generation [21]
} 
One mechanism to use these DR actions selectively is to pay end users to become partly or completely interruptible [18]. The planning, implementation and monitoring of activities designed to encourage consumers to modify patterns of electricity usage is known as Demand Side Management (DSM) [22]. DSM has been commonly used in the operation of electricity systems for years [23], but only for large industrial customers. For practical reasons, small and residential consumers have generally not been allowed to participate directly in markets. Additionally, demand response resources have been underutilized in both Europe, where the absence of initiatives on demand response could have been motivated by the inexistence of a single European energy market [24], and in the U.S., where existing demand response programs have the capacity to offset only $4 \%$ of current U.S. peak demand [25],[14].

DR is becoming more automatic and easier to implement for customers since electricity prices and similar information can now be automatically delivered and because communication technology is more accessible [26]. System operators can therefore allow customers to participate in different DR alternatives. Since the year 2000, in both the USA [18], [27] and Europe [5], research has been carried out in order to develop new DSM programs which involve commercial and residential customers in the operation of the electricity systems. Their main characteristics are detailed in the following sections.

\subsection{Classification of Demand Response Programs}

Existing DR programs can be divided into two main groups [20], [16], [28] as shown in Figure 2, according to the usefulness that such actions may have for the system operator when contingencies occur. Consequently, there are programs focused on solving reliability problems such as energy imbalances or technical restriction [25], as 
well as other programs aimed at encouraging the customer to use energy during cheaper periods.

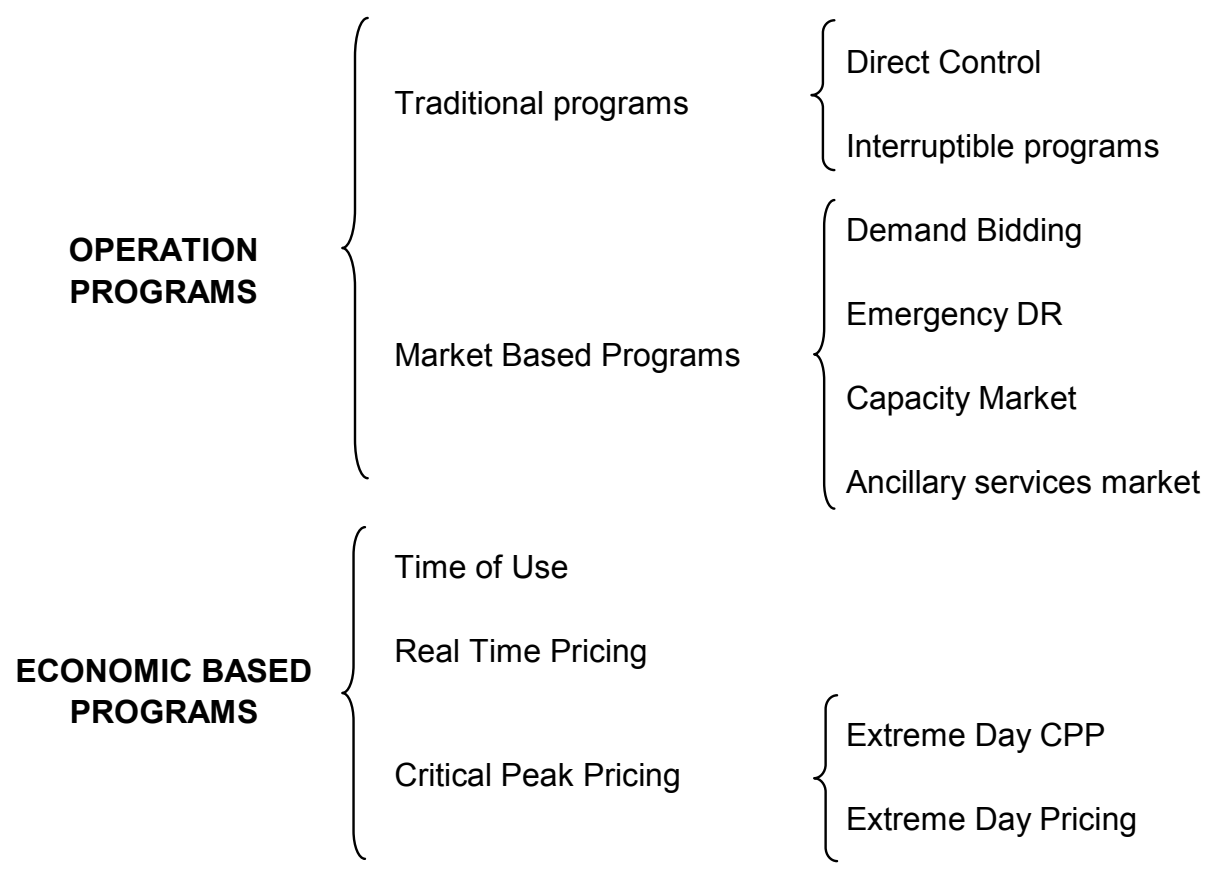

Figure 2. Classification of demand response programs This figure shows the different types of demand response programs developed around the world. Two basic types are offered. In the first groups, Operation Programs (OP), customer participation is requested when system reliability events appear, either as capacity reserves or by means of interruptible programs. The second group, Economic Based Programs (EPB), is based on voluntary demand bidding programs in response to wholesale electricity price signals [28].

These two blocks can be described as follows:

- Operation programs (OP), also called incentive based (IBP) [20], systemled or stability-based DR programs [16]. Consumers that participate in these types of programs are asked to reduce their consumption when grid operators or LSEs consider that there is a situation that could affect system stability. In that case, consumers are paid for not consuming energy as a response to the operator or LSE request. As a result, the 
consumer changes its role from client to services provider, whereas the system is actually the client of the consumer.

- Economic Based programs (EBP), also known as price-based (PBP) [20] or market-led DR programs [16]. This is a market option for the customer, which can make a profit if it reduces its energy consumption during onpeak periods, when market prices are higher. The customer can take advantage of lower price periods, avoiding consumption when electricity is more expensive.

\subsubsection{Operation Programs}

As stated above, OPs are activated by the grid operator or the LSE when a contingency occurs that could affect the stability or secure operation of the grid. Operation programs can be divided into traditional programs and market-based programs [20], [29].

In traditional programs, the customer who participates receives a discount rate or a bill credit for its participation in the program. On the other hand, customers who participate in market-based programs receive a direct cash payment, whose amount varies depending on the amount of power actually reduced during the contingency.

Traditional programs are divided into the following categories:

- Direct control programs: the operator of the program is able to switch off and switch on some customer devices by remote control on short notice. This type of program has been commonly contracted by residential or small commercial customers, and it has been applied to water heaters or air conditioning devices.

- Interruptible programs: the operator of the program does not directly act

on customer equipment, so customers must reduce the power they 
require from the grid to predefined values when they are requested to do so by the program operator. If the response is inadequate, the customer may face penalties.

Similarly, market-based programs can be classified as follows:

- Demand bidding programs: the customer bids for a specific load reduction in the wholesale electricity market. As with interruptible programs, if the customer does not respond adequately, it faces penalties.

- Emergency DR programs: the customer receives incentives for not consuming during emergency conditions when generation reserves are low.

- Capacity market programs: the customer offers a load interruption in order to substitute system capacity, usually supplied by conventional generation or delivery resources. Customers are usually notified the day before the interruption, and they receive a payment in advance as capacity remuneration. Similarly to other programs, customers who do not fulfill their commitment must pay a penalty.

- Ancillary services market: the customer can bid for load reductions in the spot market as operating reserve. If bids are accepted, customers are paid the market price for their capacity. If their load reductions are actually required, system operators ask customers to reduce consumption, and they receive an additional payment at the spot market price. 


\subsubsection{Economic Based Programs}

In EBPs, customers do not reduce their loads to contribute towards solving any emergency or contingency in the system, but rather to take advantage of the different prices of the electricity market in different time periods.

EBPs are based on dynamic pricing rates, so customers are able to offer demand reductions during peak periods when electricity prices are higher, or additional consumption during off-peak periods, when electricity prices are lower.

EBPs can be divided into the following five categories [20], [29]:

- Time of use (TOU): this is the most common type of EBP, and it consists of using rates with different electricity prices for different time periods, usually defined within a 24-hour day. Associated prices normally aim to reflect the average cost of generating and delivering power during those time periods. The simplest TOU program has just two periods: the onpeak period (daytime period) and off-peak period (nighttime and sometimes also holidays). A description of how to design TOU rates can be found in [30].

- Real Time Pricing (RTP): The price that customers have to pay when contracting this program usually varies according to changes in the wholesale electricity market. RTP customers are usually notified about the prices on a day-ahead or hour-ahead basis.

- Critical Peak Pricing (CPP): This program is a hybrid between TOU and RTP. It is based on the TOU structure, but prices are higher during critical periods and used by program operators for a limited number of days or hours a year during contingencies or when wholesale prices are higher.

There are two other EBP based on CPP programs, but with the following special features: 
- Extreme Day CPP (ED-CPP): This program establishes different prices for on-peak and off-peak periods, whereas a flat price is fixed for the rest of days.

- Extreme Day Pricing (EDP): The price is established the day before for a full 24-hour day.

\subsection{Demand Response in the United States}

The implementation of DR programs varies widely throughout the U.S. due to different factors, such as the growth of the demand, the cost of avoided capacity and the different regulations regarding DR programs in each geographic area [14]. Some states or regions such as California, Florida or New England have performed significant DR activity, while some others like Alaska, Montana or Wyoming have had little [14].
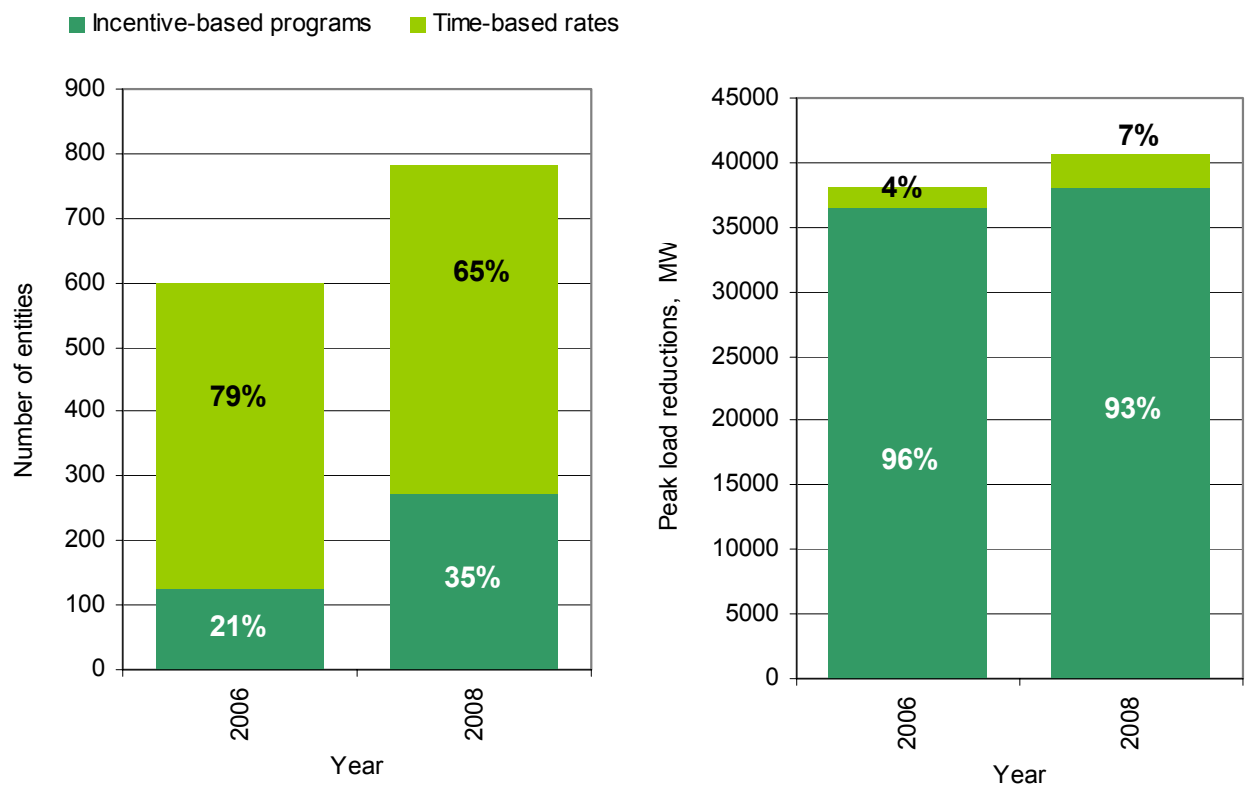

Figure 3. Number of entities offering DR and coincidental peak load reduction These figures show the number of entities offering DR as well as the total peak load reduction achieved in 2006 and 2008. In the latter year, customers who enrolled in existing wholesale and retail DR programs provided about $38,000 \mathrm{MW}$ of potential peak load reductions in the U.S. through DR incentive-based programs, which were offered by about 275 entities. [32] 
Traditionally, demand response programs in the U.S. have been offered by utility companies [31]. However, system operators have recently been offering their own. Many have been launched since 1999 due to a combination of unusual events that happened during that year, including generation shortages, congestion on the transmission grid and atypically hot weather, which worked together to increase the price of electricity. As a result, many organizations now offer DR programs in both regulated retail markets and competitive wholesale markets [28]. Figure 3 shows the estimated size of DR programs in the U.S.

\subsubsection{Operation and Market Organization in the United States of America}

A System Operator (SO) is an organization which controls, coordinates and monitors the operation of the power grid in a given geographic region or area. When an SO works in a single state, it is called an Independent System Operator (ISO), whereas SOs that operate in more than one state are called Regional Transmission Operators (RTO).

According to this definition, seven SOs are currently operating in the U.S. Three of them are ISOs, and the rest are classified as RTOs, as shown in Table 1 and Figure 4.

Together with these seven areas, which act as a marketplace in wholesale power (especially since the electricity market deregulation process carried out in the 1990s), there are another three marketplaces for the regions where no ISO or RTO is present. These are the northwest, southeast and southwest markets, as shown in Figure 5.

The Northwestern market includes the states of Washington, Oregon, Idaho, Utah, Nevada, Montana, Wyoming and part of California. The Southeastern market includes Florida, Arkansas, Louisiana, Mississippi, Alabama, Georgia, Tennessee, North Carolina, South Carolina and parts of Missouri, Kentucky and Texas. Finally, the 
Southwestern market includes Arizona, New Mexico, Colorado and parts of Nevada, Wyoming and South Dakota.

Table 1. System operators in the United States of America

\begin{tabular}{|c|c|c|}
\hline Type & System Operator & States where it operates \\
\hline \multirow{3}{*}{ ISO } & $\begin{array}{l}\text { New York Independent System } \\
\text { Operator }\end{array}$ & New York \\
\hline & $\begin{array}{l}\text { Electric Reliability Council of } \\
\text { Texas }\end{array}$ & Texas \\
\hline & $\begin{array}{l}\text { California Independent System } \\
\text { Operator }\end{array}$ & California \\
\hline \multirow{4}{*}{ RTO } & $\begin{array}{l}\text { Independent System Operator - } \\
\text { New England }\end{array}$ & $\begin{array}{l}\text { Connecticut, Maine, Massachusetts, New } \\
\text { Hampshire, Rhode Island and Vermont }\end{array}$ \\
\hline & PJM Interconnection LLC & $\begin{array}{l}\text { Delaware, Illinois, Indiana, Kentucky, Maryland, } \\
\text { Michigan, New Jersey, North Carolina, Ohio, } \\
\text { Pennsylvania, Tennessee, Virginia, West Virginia } \\
\text { and the District of Columbia }\end{array}$ \\
\hline & Southwest Power Pool & $\begin{array}{l}\text { Arkansas, Kansas, Louisiana, Missouri, } \\
\text { Nebraska, New Mexico, Oklahoma, and Texas }\end{array}$ \\
\hline & $\begin{array}{l}\text { Midwest Independent } \\
\text { Transmission System Operator }\end{array}$ & $\begin{array}{l}\text { Illinois, Indiana, lowa, Kentucky, Michigan, } \\
\text { Minnesota, Missouri, Montana, North Dakota, } \\
\text { Ohio, South Dakota, Pennsylvania, Wisconsin, } \\
\text { and Manitoba (Canada) }\end{array}$ \\
\hline
\end{tabular}

Source: "A primer on demand response..." [31]

In Table 2, the main characteristics of each one of these markets are shown. Among other parameters, mean prices in 2007 and 2009 are included, illustrating the dramatic decrease in wholesale electricity prices over those two years.

Recently, many RTOs have begun to offer different DR programs, allowing customers to bid into the capacity market. Proof of this is the increasing amount of DR resources in PJM, ISO-NE and the NY-ISO, which reached 12 GW in 2009 [33].

DR programs offered by ISOs and RTOs in the U.S. are described below.

${ }_{4}$ Despite its name, the ISO-NE is not an Independent System Operator, but a Regional Transmissions Operator 


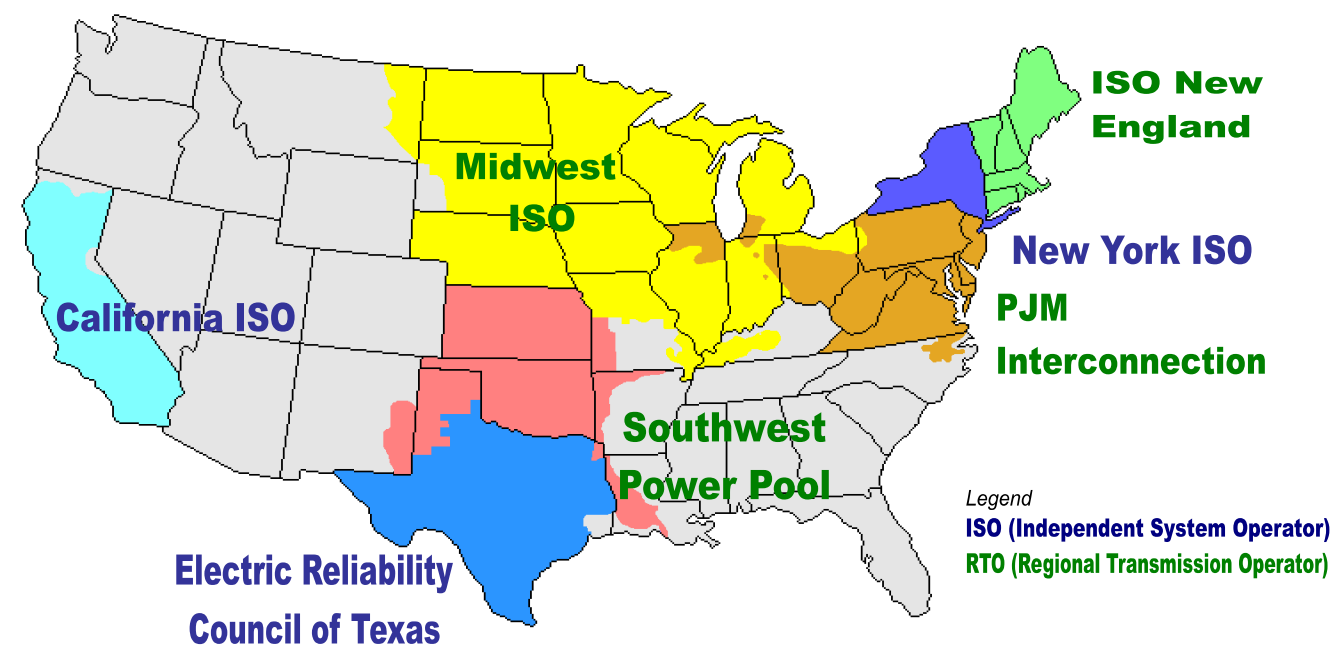

Figure 4. Map of system operators in the U.S.

In blue, there are three ISOs, working in California, Texas and New York. The other four operators work in more than one state, so they are called Regional System Operators (RTOs). This is the case in New England (ISO-NE), the Pennsylvania-Jersey-Maryland area (PJM), and the central strip of the country divided into two regions, midwest (MISO) and southern (SPP).

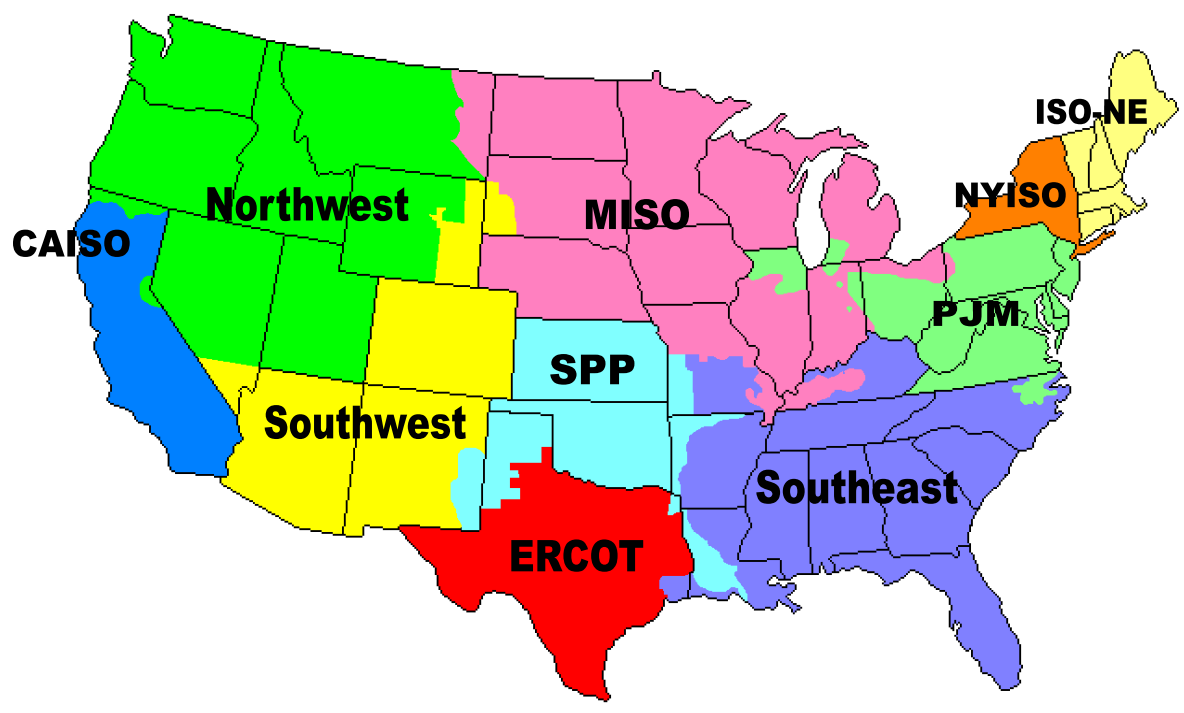

Figure 5. Map of the electricity markets in the U.S.

Besides the markets constituted by the seven operation areas, there are other three markets where no system operators are present. These are the Northwest, Southwest and Southeast areas. 
Table 2. Main characteristics of electricity markets in the U.S.

\begin{tabular}{|c|c|c|c|c|c|c|c|}
\hline \multirow{2}{*}{ Market } & \multirow{2}{*}{$\begin{array}{l}\text { System } \\
\text { Operator }\end{array}$} & \multirow{2}{*}{$\begin{array}{l}\text { Marginal } \\
\text { Fuel Type }\end{array}$} & \multirow{2}{*}{$\begin{array}{c}\text { Generating } \\
\text { capacity } \\
\text { GW }\end{array}$} & \multirow{2}{*}{$\begin{array}{l}\text { All time } \\
\text { peak } \\
\text { demand } \\
\text { GW }\end{array}$} & \multirow{2}{*}{$\begin{array}{l}\text { Price } \\
\text { areas }\end{array}$} & \multicolumn{2}{|c|}{$\begin{array}{l}\text { Mean prices } \\
\$ / M W h\end{array}$} \\
\hline & & & & & & 2007 & 2009 \\
\hline \multirow{2}{*}{ NYISO } & \multirow{2}{*}{$\begin{array}{l}\text { New York } \\
\text { Independent } \\
\text { System Operator }\end{array}$} & \multirow{2}{*}{$\begin{array}{l}\text { Natural } \\
\text { gas }\end{array}$} & \multirow{2}{*}{39.70} & \multirow{2}{*}{33.94} & $\begin{array}{c}\text { Zone J } \\
\text { (NY } \\
\text { City) }\end{array}$ & 77.09 & 55.77 \\
\hline & & & & & $\begin{array}{c}\text { Zone K } \\
\text { (Long } \\
\text { Isl.) }\end{array}$ & 86.71 & 49.8 \\
\hline ERCOT & $\begin{array}{l}\text { Electric } \\
\text { Reliability } \\
\text { Council of Texas }\end{array}$ & $\begin{array}{l}\text { Coal and } \\
\text { natural gas }\end{array}$ & 71.24 & 62.50 & $\begin{array}{l}\text { North } \\
\text { Hub }\end{array}$ & 51.96 & 26.59 \\
\hline \multirow{2}{*}{ CAISO } & \multirow{2}{*}{$\begin{array}{l}\text { California } \\
\text { Independent } \\
\text { System Operator }\end{array}$} & \multirow{2}{*}{$\begin{array}{l}\text { Natural } \\
\text { gas }\end{array}$} & \multirow{2}{*}{56.35} & \multirow{2}{*}{50.27} & NP-15 & 54.44 & 39.29 \\
\hline & & & & & SP-15 & 54.45 & 38.31 \\
\hline ISO-NE & $\begin{array}{l}\text { ISO - New } \\
\text { England }\end{array}$ & $\begin{array}{l}\text { Natural } \\
\text { gas }\end{array}$ & 30.88 & 28.13 & $\begin{array}{l}\text { Mass } \\
\text { Hub }\end{array}$ & 67.97 & 46.24 \\
\hline PJM & $\begin{array}{l}\text { PJM } \\
\text { Interconnection } \\
\text { LLC }\end{array}$ & $\begin{array}{l}\text { Coal and } \\
\text { natural gas }\end{array}$ & 157.32 & 144.64 & $\begin{array}{c}\text { PJM } \\
\text { Western }\end{array}$ & 57.00 & 44.6 \\
\hline SPP & $\begin{array}{l}\text { Southwest } \\
\text { Power Pool }\end{array}$ & $\begin{array}{l}\text { Coal and } \\
\text { natural gas }\end{array}$ & 50.60 & 42.89 & $\begin{array}{l}\text { SPP } \\
\text { North }\end{array}$ & 60.21 & 32.94 \\
\hline MISO & $\begin{array}{l}\text { Midwest } \\
\text { Independent } \\
\text { Transmission } \\
\text { System Operator }\end{array}$ & Coal & 137.23 & 116.00 & $\begin{array}{l}\text { Cinergy } \\
\text { Hub }\end{array}$ & 46.12 & 34.65 \\
\hline \multirow{2}{*}{ NORTHWEST } & \multirow{2}{*}{ None } & \multirow{2}{*}{$\begin{array}{l}\text { Hydro and } \\
\text { natural gas }\end{array}$} & \multirow[b]{2}{*}{57.12} & \multirow[b]{2}{*}{40.50} & $\mathrm{COB}$ & 62.14 & 38.02 \\
\hline & & & & & Mid-C & 56.57 & 35.66 \\
\hline SOUTHEAST & None & $\begin{array}{c}\text { Coal and } \\
\text { natural gas }\end{array}$ & 299.71 & 237.10 & $\begin{array}{c}\text { Into } \\
\text { Southern }\end{array}$ & 59.10 & 36.58 \\
\hline SOUTHWEST & None & $\begin{array}{l}\text { Natural } \\
\text { gas }\end{array}$ & 45.459 & 36.52 & $\begin{array}{l}\text { Palo } \\
\text { Verde }\end{array}$ & 61.74 & 34.77 \\
\hline
\end{tabular}

Source: $\underline{\text { http://www.ferc.gov }}$ 


\subsubsection{DR Programs Offered by System Operators}

The System Operators, ISOs and RTOs, are playing a significant role in the development of Demand Response markets. Currently, most System Operators allow customers to participate as demand resources in some of the markets they manage, including Day-Ahead markets, Real-Time markets and Ancillary Services [15].

Indeed, the highest growth of incentive-based DR resources has happened in organized wholesale markets administered by ISOs and RTOs [32]. Namely, the most significant results in DR are currently being achieved in the New York ISO, ISO New England, PJM and California ISO, mainly due to two reasons [31]:

- They operate in the most resource-constrained regions of the United States.

- There is no upper limit on demand response capacity that can be called on when a grid event is produced.

DR programs managed by ISOs and RTOs resulted in a total of 31,695 megawatts of available demand response in North America in 2009 [34].

The main characteristics of DR programs currently offered by ISOs and RTOs in the U.S. are described below.

\subsubsection{New York ISO}

The New York ISO has traditionally offered three different incentive-based DR programs: Emergency Demand Response Program (EDRP), Installed Capacity Special Case Resource Program (SCR), and the Day-Ahead Demand Response Program (DADRP). Apart from these, one other program exists, the Demand Side Ancillary Services Program (DSASP), as described below.

On July 7, 2010, 38 aggregators and eight utilities enrolled as Demand Response Service Providers in the NYISO area [35]. 


\subsection{Emergency Demand Response Program (EDRP) [36]}

This is a short-notice program based on the ability of customers to voluntarily reduce their demand for a short period of time in exchange for payment [37].

The program allows wholesale electricity market participants to provide voluntary load reductions during emergency conditions, so no penalties are imposed to enrolled customers for not responding when they are contacted by the ISO. This is compatible with all other DR programs except SCR. In order to participate, customers must offer at least $100 \mathrm{~kW}$ of reducible power per zone (aggregation allowed if the aggregated offer is at least $0.5 \mathrm{MW}$ ) with at least two hours advance notice. A day-ahead advisory notification could also be sent to inform customers that their resources may be required the following day. The response must be sustained during a period of at least four hours.

\subsection{Installed Capacity Special Case Resources [38]}

Customers enrolled in this program provide the system with two services: energy and capacity. Participants receive a payment in advance for capacity and an additional payment for load reductions when they are produced. In this case, penalties are applied to customers when they do not respond to required load reductions.

A minimum offer of at least $100 \mathrm{~kW}$ per zone is required, and participation is voluntary. The customer receives two hours advance notice, although a day-ahead optional notification could take place, just as in the EDRP program. Likewise, the response must be sustained for a period of at least four hours.

\subsection{Day-Ahead Demand Response Program [39]}

This is an economic-based bidding voluntary program aimed at reducing the total day-ahead production costs. Thus, customers present demand reduction bids, which are accepted when the cost of such interruptions is lower than the scheduled generation 
cost, so they compete side-by-side with generators. Average energy bids must be at least $\$ 50 / \mathrm{MWh}$ in the day-ahead market in order to be admitted in the program. If bids are accepted, participants are notified in advance by 11:00 am on the day before the scheduled load interruption.

Demand resource providers (host and non-host LSEs) present bids for a specific amount of power to be interrupted for at least one hour. Bids are grouped in packages of a minimum of $1 \mathrm{MW}$ by bus. A single bid cannot be longer than eight hours. Aggregators are allowed to participate if they present bids of at least $2 \mathrm{MW}$. The payment received by the customer depends on the amount of reduced power, which is calculated as the difference between the metered load during the interruption and a statistically estimated baseline. Penalties are applied if the service provider fails to fulfill its commitment.

\subsection{Demand Side Ancillary Services Program [14]}

By means of this economic-based program, customers with the required telemetry equipment are allowed to bid their load reduction capability into the real-time market.

There are three types of DSASPs, depending on the response time. Type 1 is effectively instantaneous, Type 2 has a response time of 10 minutes, and finally, Type 3 has a response time which varies between 10 and 30 minutes.

Types 2 and 3 are used to provide operating reserves, whereas type 1 is employed as a regulation service.

Similarly to DADRP, bids are grouped in packages of a minimum of $1 \mathrm{MW}$, but in this case, aggregation is not allowed. Customers are notified by 11:00 am the previous day if their capacity bids have been accepted. If energy reductions are required, customers receive a final notification 75 minutes ahead of time for types 2 and 3 , and five minutes for type 1 . 
Table 3. Summary of the DR programs offered by the New York ISO

\begin{tabular}{|c|c|c|c|c|c|c|c|}
\hline Name & $\begin{array}{c}\text { Day-Ahead } \\
\text { Demand } \\
\text { Response } \\
\text { Program }\end{array}$ & $\begin{array}{l}\text { Demand } \\
\text { Side } \\
\text { Ancillary } \\
\text { Services } \\
\text { Program (I) }\end{array}$ & $\begin{array}{c}\text { Demand } \\
\text { Side } \\
\text { Ancillary } \\
\text { Services } \\
\text { Program (II) }\end{array}$ & $\begin{array}{c}\text { Demand } \\
\text { Side } \\
\text { Ancillary } \\
\text { Services } \\
\text { Program (III) }\end{array}$ & $\begin{array}{c}\text { Emergency } \\
\text { Demand } \\
\text { Response } \\
\text { Program }\end{array}$ & $\begin{array}{c}\text { Installed } \\
\text { Capacity } \\
\text { Special Case } \\
\text { Resources } \\
\text { (Capacity } \\
\text { Component) }\end{array}$ & $\begin{array}{c}\text { Installed } \\
\text { Capacity } \\
\text { Special Case } \\
\text { Resources } \\
\text { (Energy } \\
\text { Component) } \\
\end{array}$ \\
\hline $\begin{array}{l}\text { Primary } \\
\text { Driver }\end{array}$ & Economic & Economic & Economic & Economic & Reliability & Reliability & Reliability \\
\hline $\begin{array}{l}\text { Type of } \\
\text { Service }\end{array}$ & Energy & Regulation & Reserve & Reserve & Energy & Capacity & Energy \\
\hline $\begin{array}{l}\text { Minimum } \\
\text { size }\end{array}$ & $1 \mathrm{MW}$ & $1 \mathrm{MW}$ & $1 \mathrm{MW}$ & $1 \mathrm{MW}$ & $\begin{array}{c}100 \text { kW } \\
\text { (per zone) }\end{array}$ & $\begin{array}{c}100 \text { kW } \\
\text { (per zone) }\end{array}$ & $\begin{array}{c}100 \text { kW } \\
\text { (per zone) }\end{array}$ \\
\hline $\begin{array}{l}\text { Aggregation } \\
\text { allowed }\end{array}$ & Yes & No & No & No & Yes & Yes & Yes \\
\hline Participation & Voluntary & Voluntary & Voluntary & Voluntary & Voluntary & Voluntary & Voluntary \\
\hline $\begin{array}{l}\text { Response } \\
\text { Required }\end{array}$ & Mandatory & Mandatory & Mandatory & Mandatory & Voluntary & Mandatory & Mandatory \\
\hline $\begin{array}{c}\text { Advance } \\
\text { Notification }\end{array}$ & $\begin{array}{l}\text { Day-Ahead } \\
\text { by } 11 \mathrm{am}\end{array}$ & $\begin{array}{l}\text { Day-Ahead } \\
\text { by } 11 \mathrm{am} \\
\text { Real-time: } 5 \\
\text { min }\end{array}$ & $\begin{array}{c}\text { Day-Ahead } \\
\text { by } 11 \text { am } \\
\text { Real-time: } 75 \\
\text { min }\end{array}$ & $\begin{array}{c}\text { Day-Ahead } \\
\text { by } 11 \text { am } \\
\text { Real-time: } 75 \\
\text { min }\end{array}$ & $\begin{array}{l}\text { Day-ahead } \\
\text { advisory } \\
\text { Day-of: } 2 \text { h }\end{array}$ & $\begin{array}{l}\text { Day-ahead } \\
\text { advisory } \\
\text { Day-of: } 2 \text { h }\end{array}$ & $\begin{array}{l}\text { Day-ahead } \\
\text { advisory } \\
\text { Day-of: } 2 \text { h }\end{array}$ \\
\hline $\begin{array}{l}\text { Ramp } \\
\text { Period }\end{array}$ & - & Instant. & $10 \min$ & $\begin{array}{l}10 \mathrm{~min} \text { to } \\
30 \mathrm{~min}\end{array}$ & 2 hours & 2 hours & 2 hours \\
\hline Duration & $\begin{array}{c}\text { As } \\
\text { Scheduled / } \\
\text { Dispatched }\end{array}$ & $\begin{array}{c}\text { As } \\
\text { Scheduled / } \\
\text { Dispatched }\end{array}$ & $\begin{array}{c}\text { As } \\
\text { Scheduled / } \\
\text { Dispatched }\end{array}$ & $\begin{array}{c}\text { As } \\
\text { Scheduled / } \\
\text { Dispatched }\end{array}$ & $\begin{array}{c}4 \text { Hours } \\
\text { (Minimum) }\end{array}$ & $\begin{array}{c}4 \text { Hours } \\
\text { (Minimum) } \\
\text { [or } 1 \text { Hour for } \\
\text { Test] }\end{array}$ & $\begin{array}{c}4 \text { Hours } \\
\text { (Minimum) }\end{array}$ \\
\hline $\begin{array}{c}\text { Telemetry } \\
\text { Requirement }\end{array}$ & No & Yes & Yes & Yes & No & No & No \\
\hline
\end{tabular}

Source: North American Wholesale Electricity DR Program Comparison, 2009 [33]

\subsubsection{ISO - New England}

The experience of DR resources in New England has grown significantly since 2003 due to the new market rules fixed in the Standard Market Design [40]. 
Customers in the ISO-NE area currently have the possibility of participating in six DR programs, grouped into two different blocks:

- Reliability Programs, which include three different Real-Time Demand Response Programs (RTDR).

- Price Response Programs, including Real-Time Price (RT-Price) and the Day-Ahead Load Response Program (DALRP) [32], [42].

In 2006, ISO-NE, together with the New England Power Pool (NEPOOL), launched the Demand Response Reserves Pilot (DRR-Pilot), a new program focused on analyzing the behavior of small demand response resources (load reductions lower than $5 \mathrm{MW}$ ) faced with frequent activation due to emergency situations [40].

Finally, customers may participate in the Forward Capacity Market ${ }^{5}$ (FCM) as a Demand Resource in one of the following forms, known as Other Demand Resources (ODR) [41]:

- Real Time Demand Response Resource

- Real Time Emergency Generation Resource (RTEGR)

- On-peak resource

- Seasonal Peak Resource

Total enrollments in December 2009 were 2998 MW, which represents a significant increment during that year. The most successful products were the 30 -Minute and Two-Hour Demand-Response Programs and ODR, whereas enrollments in the Real-Time Price Response program decreased a little. In total, Demand Resources provided 507 GWh of load reduction in 2009 [42].

${ }^{5}$ The FCM is a forward market, based on capacity auctions where generators and demand resources can bid, which procures the amount of capacity needed in the New England Control Area for each one-year period, from June 1 through May 31 [44]. 


\subsection{Real-Time Demand Response Programs [32], [42], [43]}

There are three options for customers who wish to participate in Real Time Demand Response Programs:

- Real-time 30-minute Demand Response Program: Customers have to offer a minimum of $100 \mathrm{~kW}$, individually or aggregately, to be reduced when required by the System Operator within 30 minutes and for at least two hours. Customers receive payments for both capacity and energy reductions. Capacity payments are based on the Forward Capacity market and are settled monthly. Energy payments are greater than RealTime wholesale price, with a minimum of $\$ 0.50 / \mathrm{kWh}$. Telemetry is compulsory, with a reporting interval of 5 minutes.

- Real-time two-hour Demand Response Program: Customers must offer a minimum of $100 \mathrm{~kW}$, individually or aggregately, to be reduced when required by the System Operator, within two hours and for at least another two hours. Like the 30-minute program, customers receive payments for both capacity and energy reductions. Capacity payments are based on the Forward Capacity Market, and are settled monthly. Energy payments are greater than Real-Time wholesale price, with a minimum of $\$ 0.35 / \mathrm{kWh}$. Telemetry is compulsory, with a reporting interval of five minutes.

- Real-time Profiled Program: This program is designed for customers with loads under their direct control that can be interrupted within two hours when required by the System Operator. Telemetry is not required, but participants must submit a measurement and verification plan to the System Operator, who has to approve it. 


\subsection{Real-Time Price [44], [45]}

The RT-Price program is open to any customer who can voluntarily reduce their electricity consumption by a minimum of $100 \mathrm{~kW}$ in response to a notification by ISO New England. Aggregators can represent several facilities together to achieve the minimum $100 \mathrm{~kW}$, and there are no penalties for customers who do not reduce their load.

The program is activated when the ISO forecasts any hourly pricing regimen for the following day which exceeds $\$ 100 / \mathrm{MWh}$. In that case, the ISO notifies the enrolled customers, and they decide to reduce their load voluntarily. If they do, they receive the Real-Time zonal price as a payment for interrupted consumption, at a minimum rate of \$100/MWh.

The reduced load for each customer is calculated as the difference between the real consumption during the interruption and the baseline average of the 10 previous non-event business days, conveniently adjusted with real data from the date of the interruption. Logically, telemetry is compulsory to participate in this program.

Owners of on-site and emergency generators such as hospitals, data centers, office buildings, warehouses and industrial locations are eligible to participate in this program [46]. The most frequent actions that customers carry out to achieve the required load reductions in this program are as simple as asking employees to conserve energy (75\%), turning off some lighting (65\%) or adjusting the indoor temperature $(53 \%)$.

\subsection{Day-Ahead Load Response [44], [47]}

The DALRP program allows the customer to offer energy reductions for the following day at minimal increments of $100 \mathrm{~kW}$, either individually or aggregately. Such offers consider the amount of power that the customer is willing to reduce, the minimum duration of the interruption and the payment required by the customer to interrupt. 
Customers in this program can also participate in the FCM, except if they are already participating in the RT-Price response program.

The minimum offer to be presented is based on the reserve fuel cost, which is calculated once a month, with a maximum value of $\$ 1,000 / \mathrm{MWh}$. The payment that the customer receives is based on electricity prices set in the Day-Ahead Energy Market.

If an offer is accepted, the customer is notified the day before the interruption by 4:00 pm.

\subsection{Other Demand Resources in the Forward Capacity Market [48], [49]}

The FCM purchases enough capacity for reliable system operation for one future year at competitive prices when all resources can participate, including Demand Resources.

The specific demand resources created by the FCM to achieve this objective consist of energy-efficiency programs, load management programs and distributed generation.

The amount of capacity offered by a customer to participate in this program must be higher or equal to $100 \mathrm{~kW}$, individually or aggregately [50].

Four different products are defined to allow demand resources to participate in the FCM; these are divided into two categories:

- Demand response products, including RTDR and RTEGR.

- Other Demand Products, including On-peak Resources and Seasonal Peak Resources.

The main characteristics of each one of these products are detailed in Table 4. 
Table 4. Summary of the DR programs offered by the ISO - New England

\begin{tabular}{|c|c|c|c|c|c|c|c|}
\hline \multirow[b]{2}{*}{ Name } & \multirow{2}{*}{$\begin{array}{c}\text { RELIABILITY } \\
\text { PROGRAMS } \\
\text { Real Time } \\
\text { Demand } \\
\text { Response } \\
\text { Program } \\
\end{array}$} & \multicolumn{2}{|c|}{$\begin{array}{l}\text { PRICE RESPONSE } \\
\text { PROGRAMS }\end{array}$} & \multicolumn{3}{|c|}{ OTHER DEMAND RESOURCES } & \multirow{2}{*}{$\begin{array}{c}\text { PILOT } \\
\text { Demand } \\
\text { Response } \\
\text { Reserves } \\
\text { Pilot } \\
\end{array}$} \\
\hline & & $\begin{array}{l}\text { Real Time } \\
\text { Price } \\
\text { Response } \\
\text { Program }\end{array}$ & $\begin{array}{c}\text { Day-Ahead } \\
\text { Load } \\
\text { Response } \\
\text { Program for } \\
\text { RTDRP } \\
\end{array}$ & $\begin{array}{l}\text { Real Time } \\
\text { Demand } \\
\text { Response } \\
\text { Resource }\end{array}$ & $\begin{array}{l}\text { Real Time } \\
\text { Emergency } \\
\text { Generation } \\
\text { Resource }\end{array}$ & $\begin{array}{l}\text { FCM: On-' } \\
\text { Peak, } \\
\text { Seasonal } \\
\text { Peak } \\
\text { Resources } \\
\end{array}$ & \\
\hline $\begin{array}{l}\text { Primary } \\
\text { Driver }\end{array}$ & Reliability & Economic & Economic & Reliability & Reliability & Reliability & Reliability \\
\hline $\begin{array}{l}\text { Type of } \\
\text { Service }\end{array}$ & $\begin{array}{l}\text { Capacity and } \\
\text { Energy }\end{array}$ & Energy & Energy & Capacity & Capacity & Capacity & Reserve \\
\hline $\begin{array}{l}\text { Minimum } \\
\text { size }\end{array}$ & $100 \mathrm{~kW}$ & $100 \mathrm{~kW}$ & 100 kW & $100 \mathrm{~kW}$ & $100 \mathrm{~kW}$ & $100 \mathrm{~kW}$ & $100 \mathrm{~kW}$ \\
\hline $\begin{array}{l}\text { Aggregation } \\
\text { allowed }\end{array}$ & Yes & Yes & Yes & Yes & Yes & Yes & Yes \\
\hline Participation & Voluntary & Voluntary & Voluntary & Voluntary & Voluntary & Voluntary & Voluntary \\
\hline $\begin{array}{l}\text { Response } \\
\text { Required }\end{array}$ & Mandatory & Voluntary & Mandatory & Mandatory & Mandatory & Mandatory & Mandatory \\
\hline $\begin{array}{l}\text { Advance } \\
\text { Notification }\end{array}$ & None & None & $\begin{array}{l}\text { Day-Ahead } \\
\text { Market } \\
\text { Clearing } \\
(\sim 4: 00 \mathrm{pm})\end{array}$ & $\begin{array}{l}10 \mathrm{pm} \text { on } \\
\text { the day } \\
\text { prior to the } \\
\text { call for DR } \\
\text { Forecast } \\
\text { Peak } \\
\text { Hours, in } \\
\text { each hour } \\
\text { for RT DR } \\
\text { Dispatch } \\
\text { Hours }\end{array}$ & None & None & None \\
\hline $\begin{array}{l}\text { Ramp } \\
\text { Period }\end{array}$ & $\begin{array}{l}10 \text { Minutes/ } \\
30 \text { Minutes }\end{array}$ & $\begin{array}{c}\text { Effectively } \\
\text { Instantaneous }\end{array}$ & $\begin{array}{c}\text { Effectively } \\
\text { Instantaneous }\end{array}$ & 30 Minutes & 30 Minutes & $\begin{array}{l}\text { Effectively } \\
\text { Instantaneous }\end{array}$ & 30 Minutes \\
\hline Duration & $\begin{array}{c}\text { As } \\
\text { Scheduled / } \\
\text { Dispatched }\end{array}$ & $\begin{array}{c}\text { As } \\
\text { Scheduled / } \\
\text { Dispatched }\end{array}$ & $\begin{array}{c}\text { As } \\
\text { Scheduled / } \\
\text { Dispatched }\end{array}$ & $\begin{array}{c}\text { As } \\
\text { Scheduled / } \\
\text { Dispatched }\end{array}$ & $\begin{array}{c}\text { As } \\
\text { Scheduled / } \\
\text { Dispatched }\end{array}$ & $\begin{array}{l}\text { On-Peak: } \\
\text { Jun, Jul, Aug } \\
\text { hours ending } \\
\text { 1pm to } 5 \mathrm{pm} \text {. } \\
\text { Dec., Jan. } \\
\text { hours ending } \\
5 \mathrm{pm} \text { to } 7 \mathrm{pm} . \\
\\
\text { Seasonal } \\
\text { Peak - As } \\
\text { Scheduled }\end{array}$ & $\begin{array}{c}\text { As } \\
\text { Scheduled } \\
\text { Dispatched }\end{array}$ \\
\hline $\begin{array}{c}\text { Telemetry } \\
\text { Requirement }\end{array}$ & $\begin{array}{l}\text { Yes, except } \\
\text { for RT- } \\
\text { Profiled }\end{array}$ & No & No & Yes & Yes & No & Yes \\
\hline
\end{tabular}

Source: North American Wholesale Electricity DR Program Comparison, 2009 [33] 


\subsection{Demand Response Reserves Pilot (DRR-Pilot) [40]}

This pilot program is focused on small customers such as supermarkets, big-box retailers or aggregations of residential air-conditioning devices without emergency generation, since local and state environmental regulations do not allow its operation if no emergency situation is present.

Up to now, the DRR-Pilot has been activated to simulate the reaction of DR resources to reserve events, similarly to the activation of conventional generation resources, which provide 30-minute operating reserves and 10-minute non-synchronized reserves [33].

In order to participate in this program, a customer must offer a reduction of at least $100 \mathrm{~kW}$, with an upper aggregation limit of $5 \mathrm{MW}$. Telemetry is required and customers do not receive any notification prior to the interruption.

The pilot was performed in two phases and was activated on 69 occasions, for periods between 30 minutes and one hour from 7:00 am to 5:00 pm. The last phase finished in May 2010, achieving the promised value of $30 \mathrm{MW}$ of reduced load.

\subsubsection{PJM}

PJM offers its customers the possibility of participating in three incentive-based DR programs: Emergency Load Response, Full Emergency Load Management, and Economic Load Response Programs. The first two programs are activated when an emergency happens, and they differ from each other with regards to participant requirements. Additionally, the Emergency Load Response is an Energy Only program, whereas the Full Emergency one allows customers to offer capacity as well. The Economic Load Response Programs are divided into four types, and they give customers the opportunity to participate in the Real-Time energy market, either through direct or indirect scheduling [32]. 


\subsection{Emergency Load Response [51], [52]}

This program is based on voluntary reductions of consumption during emergency conditions. Customers receive payments for energy reductions, but not for capacity. They must reduce a minimum of $100 \mathrm{~kW}$, with a maximum of two hours advance notice. The payment that customers receive for reducing load is based on the actual marginal price of energy, plus an adjustment for losses.

\subsection{Full Emergency Load Management [51], [52]}

Participants are compensated with both energy and capacity payments. Similarly to the Emergency Load Response program, customers required to interrupt load must reduce a minimum of $100 \mathrm{~kW}$, with a maximum of two hours advance notice, up to a maximum of 10 times during the summer months. The payment that customers receive for reducing load is based on the actual marginal price of energy plus an adjustment for losses.

\subsection{Economic Load Response Programs [51], [52]}

Customers who participate in this program receive a payment for reducing their electricity consumption when PJM marginal prices are high.

Participants have the possibility of participating in day-ahead or real-time programs.

In the day-ahead option, customers offer voluntary reductions in advance of realtime operations. If the System Operator accepts these offers, then they receive a payment based on the day-ahead marginal prices.

In the real-time option, customers offer voluntary reductions of consumption when prices are high, so they receive payments based on real-time marginal prices. 
Table 5. Summary of the DR programs offered by the PJM Interconnection

\begin{tabular}{|c|c|c|c|c|c|c|c|}
\hline \multirow[t]{2}{*}{ Name } & $\begin{array}{c}\text { Economic } \\
\text { Load } \\
\text { Response (I) }\end{array}$ & $\begin{array}{l}\text { Economic } \\
\text { Load } \\
\text { Response } \\
\text { (II) }\end{array}$ & $\begin{array}{l}\text { Economic } \\
\text { Load } \\
\text { Response } \\
\text { (III) }\end{array}$ & $\begin{array}{l}\text { Economic } \\
\text { Load } \\
\text { Response } \\
\text { (IV) }\end{array}$ & \multirow{2}{*}{$\begin{array}{l}\text { Emergency } \\
\quad \text { Load } \\
\text { Response - } \\
\text { Energy Only }\end{array}$} & \multirow{2}{*}{$\begin{array}{c}\text { Full } \\
\text { Emergency } \\
\text { Load } \\
\text { Response } \\
\text { (Capacity } \\
\text { Component) }\end{array}$} & \multirow{2}{*}{$\begin{array}{c}\text { Full } \\
\text { Emergency } \\
\text { Load } \\
\text { Response } \\
\text { (Energy } \\
\text { Component) }\end{array}$} \\
\hline & \multicolumn{2}{|c|}{$D A Y-A H E A D$ PROGRAMS } & \multicolumn{2}{|c|}{ REAL-TIME PROGRAMS } & & & \\
\hline $\begin{array}{l}\text { Primary } \\
\text { Driver }\end{array}$ & Economic & Reliability & Reliability & Reliability & Reliability & Reliability & Reliability \\
\hline $\begin{array}{l}\text { Type of } \\
\text { Service }\end{array}$ & Energy & Reserve & Reserve & Regulation & Energy & Capacity & Energy \\
\hline $\begin{array}{l}\text { Minimum } \\
\text { size }\end{array}$ & 100 kW & $\begin{array}{c}1 \mathrm{MW} \\
(0.5 \mathrm{MW} \\
\text { proposed })\end{array}$ & $\begin{array}{c}1 \mathrm{MW} \\
(0.5 \mathrm{MW} \\
\text { proposed })\end{array}$ & $1 \mathrm{MW}$ & $100 \mathrm{~kW}$ & 100 kW & 100 kW \\
\hline $\begin{array}{l}\text { Aggregation } \\
\text { allowed }\end{array}$ & Yes & Yes & Yes & No & Yes & Yes & Yes \\
\hline Participation & Voluntary & Voluntary & Voluntary & Voluntary & Voluntary & Voluntary & Voluntary \\
\hline $\begin{array}{l}\text { Response } \\
\text { Required }\end{array}$ & Voluntary & Mandatory & Mandatory & Mandatory & Voluntary & Mandatory & Mandatory \\
\hline $\begin{array}{l}\text { Advance } \\
\text { Notification }\end{array}$ & $\begin{array}{l}\text { Day-Ahead } \\
\text { Clearing } \\
(\sim 4: 00)\end{array}$ & $\begin{array}{l}\text { Day-Ahead } \\
\text { Clearing } \\
(\sim 4: 00)\end{array}$ & 1 Hour & None & $\begin{array}{c}2 \text { Hours } \\
\text { (Maximum) }\end{array}$ & $\begin{array}{c}2 \text { Hours } \\
\text { (Maximum) }\end{array}$ & $\begin{array}{c}2 \text { Hours } \\
\text { (Maximum) }\end{array}$ \\
\hline $\begin{array}{l}\text { Ramp } \\
\text { Period }\end{array}$ & $\begin{array}{l}\text { Resource } \\
\text { Specific }\end{array}$ & 30 Minutes & 10 Minutes & $\begin{array}{l}\text { Effectively } \\
\text { Instantaneo } \\
\text { us }\end{array}$ & $\begin{array}{c}1 \text { Hour or } 2 \\
\text { Hours } \\
\text { (Participant } \\
\text { Selected) }\end{array}$ & $\begin{array}{c}1 \text { Hour or } 2 \\
\text { Hours } \\
\text { (Participant } \\
\text { Selected) }\end{array}$ & $\begin{array}{c}1 \text { Hour or } 2 \\
\text { Hours } \\
\text { (Participant } \\
\text { Selected) } \\
\end{array}$ \\
\hline Duration & $\begin{array}{c}\text { As } \\
\text { Scheduled / } \\
\text { Dispatched }\end{array}$ & $\begin{array}{c}\text { As } \\
\text { Scheduled / } \\
\text { Dispatched }\end{array}$ & $\begin{array}{c}\text { As } \\
\text { Scheduled / } \\
\text { Dispatched }\end{array}$ & $\begin{array}{c}\text { As } \\
\text { Scheduled / } \\
\text { Dispatched }\end{array}$ & $\begin{array}{c}\text { As } \\
\text { Scheduled / } \\
\text { Dispatched }\end{array}$ & $\begin{array}{c}\text { As } \\
\text { Scheduled / } \\
\text { Dispatched }\end{array}$ & $\begin{array}{c}\text { As } \\
\text { Scheduled / } \\
\text { Dispatched }\end{array}$ \\
\hline $\begin{array}{c}\text { Telemetry } \\
\text { Requirement }\end{array}$ & No & No & No & Yes & No & No & No \\
\hline
\end{tabular}

Source: North American Wholesale Electricity DR Program Comparison, 2009 [33].

\subsubsection{Electric Reliability Council of Texas}

The ERCOT electricity market is mainly a "bilateral" market, which differs from pool-type markets in other regions such as California, New York, and Pennsylvania-New Jersey-Maryland [53]. In this context, an important aspect of the ERCOT bilateral market 
is that participants in Load Reduction Programs must sign a contract with a Qualified Scheduling Entity $(\mathrm{QSE})^{6}$, which is the only entity allowed to perform scheduling and settlement services with ERCOT [54].

There are three types of programs available for customers wishing to participate in DR services: The Emergency Interruptible Load Service (EILS), the Balancing Up Load Program (BUL) and the Loads Acting as a Resource programs (LaaR).

The EILS program is provided for customers willing to interrupt demand during an electrical grid emergency in exchange for a payment [55]. It constitutes an additional tool for ERCOT Operations, but is only activated in the late stages of a grid emergency.

The BUL program is based on reductions offered by customers in the balancing energy market. Customers are only paid when they reduce the load in response to an ERCOT requirement.

The LaaR programs appeared after the ERCOT market restructuring happened in 2002, as a market-based option to substitute interruptible tariffs. Customers which currently participate in these programs offer a peak interruptible capacity of $2121 \mathrm{MW}$ [55]. LaaRs can provide ERCOT with ancillary services, which work every day for the following day. LaaR programs offer three possibilities:

- Responsive Reserve Service. These services can be further divided into two types: Under Frequency Relay type, which is the most popular option among the different LaaR programs [54],[53], and Controllable Load Resource type

- Non-Spinning Reserve Service

- Regulation Service as a Controllable Load Resource

${ }^{6}$ A Qualified Scheduling Entity is a participant in the ERCOT market which represents resource entities, retail electric providers and other similar agents in the market by submitting schedules of generation and demand on their behalf. 


\subsection{Emergency Interruptible Load Service [55]}

Customers that participate in this program pledge to interrupt part of their load in case of emergency, in order to maintain the frequency of the grid at $60 \mathrm{~Hz}$. When an emergency situation occurs, customers who participate in this program must interrupt at least $95 \%$ of their committed load within 10 minutes of receiving the instruction via phone. The reduction must be maintained until the emergency situation has been resolved and generation reserves have been restored.

Customers bid for reductions at a minimum value of $1 \mathrm{MW}$, individually or aggregately. The QSE, rather than the System Operator, is responsible for advising the customers when the program is activated. Similarly, the QSE pays the customers for participating in the program. Customers are paid as bid for capacity if their offer is accepted, since they have been available for interruption, but they do not receive any additional payment if the service is activated by ERCOT. Telemetry is compulsory, with a 15-minute interval metering or statistically valid sample approved by ERCOT. EILS contracts are usually signed for a period of four months (February-May, June-September and October-January) for one or more of the following options:

- $\quad$ Business Hours 1: 8:00 am to 1:00 pm Monday-Friday (except holidays)

- Business Hours 2: 1:00 pm to 4:00 pm Monday-Friday (except holidays)

- Business Hours 3: 4:00 pm to 8:00 pm Monday-Friday (except holidays)

- Non-Business Hours: All other hours

\subsection{Balancing Up Load Program [53]}

The BUL program began in ERCOT in September 2003. By means of this program, customers can submit offers through a QSE to the System Operator in order to provide balancing energy by reducing their power demand. The System Operator selects 
a reduction offer according to a prioritizing process based on prices, and the QSE receives a notification which is transmitted to customers to reduce their loads.

Customers are paid only if they reduce their loads, but they receive payments for capacity and energy separately. The capacity payment is based on the Non-Spinning Reserves market (ancillary services). The second payment that customers receive is due to the actual load reduction performed, and it is based on the Balancing Energy market.

\subsection{Loads Acting as a Resource Providing Responsive Reserve [53], [54],}

[56]

The System Operator uses the LaaR program when an event produces a significant deviation from the standard frequency, allowing the frequency to be restored within the first few minutes of the incident. Customers receive payments for capacity and real reduced energy.

The program is divided into two different types: Under Frequency Relay type and Controllable Load Resource type, and it is activated in one of the following ways:

- Automatically, by means of a frequency relay (Under Frequency Relay type), which must deploy within 10 minutes

- Through a verbal dispatch instruction in one of the following cases:

$\circ$ During an Energy Emergency Alert

- During a frequency event reportable to $\mathrm{NERC}^{7}$

- To solve a local congestion issue

Real-time telemetry is required to participate in this program.

7 The North American Electric Reliability Corporation (NERC) is the entity committed to ensuring the reliability of the bulk power system in North America. More information available online in http://www.nerc.com 
Table 6. Summary of the DR programs offered by the Electric Reliability Council of Texas

\begin{tabular}{|c|c|c|c|c|c|c|}
\hline \multirow[b]{2}{*}{ Name } & \multirow[b]{2}{*}{$\begin{array}{l}\text { Emergency } \\
\text { Interruptible } \\
\text { Load Service }\end{array}$} & \multirow[b]{2}{*}{$\begin{array}{l}\text { Balancing Up } \\
\text { Load Program }\end{array}$} & \multicolumn{4}{|c|}{ LOADS ACTING AS A RESOURCE (LaaRs) } \\
\hline & & & $\begin{array}{l}\text { Providing } \\
\text { Responsive } \\
\text { Reserve } \\
\text { Service -- } \\
\text { Under } \\
\text { Frequency } \\
\text { Relay Type } \\
\end{array}$ & $\begin{array}{c}\text { Providing } \\
\text { Responsive } \\
\text { Reserve Service -- } \\
\text { Controllable Load } \\
\text { Resource Type }\end{array}$ & $\begin{array}{l}\text { Providing Non- } \\
\text { Spinning } \\
\text { Reserve } \\
\text { Service }\end{array}$ & $\begin{array}{c}\text { Providing } \\
\text { Regulation } \\
\text { Service as } \\
\text { Controllable } \\
\text { Load } \\
\text { Resources }\end{array}$ \\
\hline $\begin{array}{l}\text { Primary } \\
\text { Driver }\end{array}$ & Reliability & Reliability & Reliability & Reliability & Reliability & Reliability \\
\hline $\begin{array}{l}\text { Type of } \\
\text { Service }\end{array}$ & Capacity & $\begin{array}{c}\text { Capacity and } \\
\text { Energy }\end{array}$ & Reserve & Reserve & Reserve & Regulation \\
\hline$\underset{\text { size }}{\text { Minimum }}$ & $\begin{array}{c}1 \mathrm{MW} \\
\text { (Bid Size) }\end{array}$ & $\begin{array}{c}1 \mathrm{MW} \\
\text { (Bid Size) }\end{array}$ & $\begin{array}{c}1 \mathrm{MW} \\
\text { (Bid Size) }\end{array}$ & $\begin{array}{c}1 \mathrm{MW} \\
\text { (Bid Size) }\end{array}$ & $\begin{array}{c}1 \mathrm{MW} \\
\text { (Bid Size) }\end{array}$ & $\begin{array}{c}1 \mathrm{MW} \\
\text { (Bid Size) }\end{array}$ \\
\hline $\begin{array}{l}\text { Aggregation } \\
\text { allowed }\end{array}$ & Yes & Yes & $\begin{array}{c}\text { Portfolio- } \\
\text { Based Bidding }\end{array}$ & $\begin{array}{c}\text { Portfolio- } \\
\text { Based Bidding }\end{array}$ & $\begin{array}{c}\text { Portfolio- } \\
\text { Based Bidding }\end{array}$ & $\begin{array}{c}\text { Portfolio- } \\
\text { Based Bidding }\end{array}$ \\
\hline Participation & Voluntary & Voluntary & Voluntary & Voluntary & Voluntary & Voluntary \\
\hline $\begin{array}{l}\text { Response } \\
\text { Required }\end{array}$ & Mandatory & Mandatory & Mandatory & Mandatory & Mandatory & Mandatory \\
\hline $\begin{array}{c}\text { Advance } \\
\text { Notification }\end{array}$ & None & None & $\begin{array}{l}\text { Day-Ahead } \\
\text { Market } \\
\text { Clearing } \\
(\sim 13: 30)\end{array}$ & $\begin{array}{l}\text { Day-Ahead Market } \\
\text { Clearing }(\sim 13: 30)\end{array}$ & $\begin{array}{l}\text { Day-Ahead } \\
\text { Market Clearing } \\
(\sim 13: 30)\end{array}$ & $\begin{array}{c}\text { Day-Ahead } \\
\text { Market } \\
\text { Clearing } \\
(\sim 13: 30)\end{array}$ \\
\hline Ramp Period & 10 Minutes & $\begin{array}{c}\text { Effectively } \\
\text { Instantaneous }\end{array}$ & $\begin{array}{l}10 \text { Minutes } \\
\text { (Phone) } \\
30 \text { Cycles } \\
\text { (Relay) }\end{array}$ & $\begin{array}{l}\text { Continuous, similar } \\
\text { to governor action } \\
\text { by a generator; and } \\
10 \text { min response for } \\
\text { remaining obligation } \\
\text { to electronic } \\
\text { instruction }\end{array}$ & 30 Minutes & $\begin{array}{c}\text { Effectively } \\
\text { Instantaneous }\end{array}$ \\
\hline Duration & $\begin{array}{l}\text { As Scheduled / } \\
\text { Dispatched }\end{array}$ & $\begin{array}{l}\text { AS Scheduled } \\
\text { / Dispatched }\end{array}$ & $\begin{array}{l}\text { As Scheduled } \\
\text { / Dispatched }\end{array}$ & $\begin{array}{l}\text { As Scheduled / } \\
\text { Dispatched }\end{array}$ & $\begin{array}{l}\text { As Scheduled / } \\
\text { Dispatched }\end{array}$ & $\begin{array}{l}\text { As Scheduled } \\
\text { / Dispatched }\end{array}$ \\
\hline $\begin{array}{c}\text { Telemetry } \\
\text { Requirement }\end{array}$ & No & Yes & Yes & Yes & Yes & Yes \\
\hline
\end{tabular}

Source: North American Wholesale Electricity DR Program Comparison, 2009 [33] 


\subsection{Loads Acting as a Resource Providing Non-Spinning Reserve [54], [56]}

This program provides ERCOT with additional reserves when contingencies cause the loss of generation resources. Customers are required to interrupt their loads manually (for example, by opening a circuit breaker) within 30 minutes of advance notice. The minimum size for interruptible loads is $1 \mathrm{MW}$. Real-time telemetry is required to participate in this program.

\subsection{Loads Acting as a Resource Providing Regulation Service [54], [56]}

The regulation service (up or down modes are possible) is used when an increase or decrease in the system frequency is produced, in order to maintain the target ERCOT System frequency. Participants have to increase or decrease loads automatically when it is required by the System Operator, who must receive all the information required to verify the service in real-time. Again, telemetry is compulsory, and the minimum load size to participate in this program is $1 \mathrm{MW}$.

\subsubsection{Southwest Power Pool}

There is only one DR program available in the SPP area offered by the RTO: the Variable Dispatch Demand Response Program (VDDR). Thanks to this program, about $1500 \mathrm{MW}$ were available in 2009 in the balancing market for the SPP area [57].

\subsection{Variable Dispatch Demand Response Program}

This program was launched in August 2008 as part of the existing Energy Imbalance Service (EIS) market. Customers are allowed to participate individually or by means of aggregators. Aggregators, like any other market participant, can represent demand response just as any other resource capable of responding to dispatched load reductions [58]. 
Table 7. Summary of the DR programs offered by the Southwest Power Pool

\begin{tabular}{cc}
\hline Name & Variable Dispatch Demand Response \\
\hline $\begin{array}{c}\text { Primary } \\
\text { Driver }\end{array}$ & Economic \\
$\begin{array}{c}\text { Type of } \\
\text { Service }\end{array}$ & Energy \\
\hline $\begin{array}{c}\text { Minimum } \\
\text { size }\end{array}$ & 1 MW \\
\hline $\begin{array}{c}\text { Aggregation } \\
\text { allowed }\end{array}$ & $\begin{array}{c}\text { Aggregation to a single withdrawal point } \\
\text { from the Transmission Grid (and single } \\
\text { Retail Provider) is permitted }\end{array}$ \\
\hline $\begin{array}{c}\text { Participation } \\
\text { Response } \\
\text { Required }\end{array}$ & Voluntary \\
\hline $\begin{array}{c}\text { Advance } \\
\text { Notification }\end{array}$ & Mandatory \\
\hline $\begin{array}{c}\text { Ramp } \\
\text { Period }\end{array}$ & 5 Minutes (Maximum) \\
\hline $\begin{array}{c}\text { Duration } \\
\text { Telemetry }\end{array}$ & 5 Minutes \\
\hline \\
\hline Requirement
\end{tabular}

Source: North American Wholesale Electricity DR Program Comparison, 2009 [33]

The VDDR program consists of facilities with autonomous generators capable of responding within five minutes [57]. The minimum size of a reducible load is $1 \mathrm{MW}$. Real-time telemetry is compulsory in order to verify the proper fulfillment of customer responses.

\subsubsection{Midwest ISO}

MISO occupies a wide area covering the American Midwest, as well as the province of Manitoba in Canada, as shown in Figure 4. Currently, there are three DR programs which provide approximately $8000 \mathrm{MW}$ of capacity in the Midwest ISO region [59]. They are the Emergency Demand Response Program; the Demand Response Resource Program (divided into two different types); and the Load Modifying Resource Program. 
The Emergency Demand Response Program allows customers to offer load reductions during emergency events and receive compensation in exchange.

The Demand Response Resource Program allows customers to submit offers into the MISO day-ahead energy market, subject to the same requirements as the generator [21].

Finally, the Load Modifying Resource Program, which includes Demand Resources and Autonomous Generation, allows customers to provide the System with capacity by reducing their consumption during emergencies, and may include such resources as interruptible load or direct load control [21].

\subsection{Emergency Demand Response Program [21]}

Launched in May 2008, this program is a special initiative of MISO that compensates registered resources for cutbacks during emergency events. When called upon, customers receive a payment according to the offer they have presented, with a minimum value equal to the local real-time marginal price of electricity.

About $300 \mathrm{MW}$ were provided in 2009 by customers enrolled in this service. This participation is relatively small, probably due to the small number of events which have activated the service.

Enrolled customers present daily offers for a minimum reduction of $100 \mathrm{~kW}$, individually or aggregately.

\subsection{Demand Response Resources Program [21], [60]}

Demand Response Resources (DRR) can be divided into two different types: DRR-Type I and DRR-Type II. Participation of demand resources in this program assumed a total capability of $1390 \mathrm{MW}$ in 2009, of which 1282 were provided by Type I customers ( $75 \%$ provided by a single facility), and the rest by Type II ones. 
The DRR-Type I was initially created to integrate interruptible tariffs and other Direct Load Control programs into the wholesale electricity market. This type of resource can provide a pre-specified amount of load reduction through physical load interruptions, but its output is not fully controllable.

The DRR-Type II includes dispatchable and controllable resources which can be deployed by autonomous generation or controllable load. Typically, many industrial customers prefer to participate in this type of program. Type II Resources are significantly more difficult to obtain, and they are more valuable since they can provide regulation reserves, spinning reserves and supplemental reserves.

Through the DRR program, customers can offer energy reductions in both realtime and day-ahead energy markets. Similarly, they can also provide ancillary services.

In the real-time and day-ahead energy markets, customers enrolled can bid similarly to generation resources. When an offer is accepted, the customer must reduce the load as specified in the contract. Penalties are applied when agreed upon reductions are not fulfilled.

Similarly, demand resources have also been able to participate in ancillary services since September 2008, and they can present offers to reduce their load during power system contingencies.

In both Types I and II, the minimum size of reducible load is $1 \mathrm{MW}$, but only Type I permits aggregation. On the other hand, only Type II resources can provide ancillary services such as regulation and spinning reserves, although MISO is currently investigating the possibility of allowing DRR-Type I resources to offer spinning reserves as well. 


\subsection{Load Modifying Resource Program [21]}

Customers supplying this service participate in a voluntary capacity auction, where they present offers to reduce their load when required by the System Operator.

Table 8. Summary of the DR programs offered by the Midwest ISO

\begin{tabular}{|c|c|c|c|c|c|c|c|}
\hline \multirow[b]{2}{*}{ Name } & \multirow[b]{2}{*}{$\begin{array}{c}\text { Emergency } \\
\text { Demand } \\
\text { Response }\end{array}$} & \multicolumn{5}{|c|}{ DEMAND RESPONSE RESOURCE } & \multirow[b]{2}{*}{$\begin{array}{l}\text { Load } \\
\text { Modifying } \\
\text { Resource }\end{array}$} \\
\hline & & $\begin{array}{l}\text { Type I - } \\
\text { Energy }\end{array}$ & $\begin{array}{l}\text { Type I - } \\
\text { Reserve }\end{array}$ & $\begin{array}{l}\text { Type II - } \\
\text { Energy }\end{array}$ & $\begin{array}{l}\text { Type II - } \\
\text { Reserve }\end{array}$ & $\begin{array}{l}\text { Type II - } \\
\text { Regulation } \\
\text { (ancillary } \\
\text { services) }\end{array}$ & \\
\hline $\begin{array}{l}\text { Primary } \\
\text { Driver }\end{array}$ & Reliability & Economic & Reliability & Economic & Reliability & Reliability & Reliability \\
\hline $\begin{array}{l}\text { Type of } \\
\text { Service }\end{array}$ & Energy & Energy & Reserve & Energy & Reserve & Regulation & Capacity \\
\hline $\begin{array}{l}\text { Minimum } \\
\text { size }\end{array}$ & $100 \mathrm{~kW}$ & $1 \mathrm{MW}$ & $1 \mathrm{MW}$ & $1 \mathrm{MW}$ & $1 \mathrm{MW}$ & $1 \mathrm{MW}$ & $100 \mathrm{~kW}$ \\
\hline $\begin{array}{l}\text { Aggregation } \\
\text { allowed }\end{array}$ & Yes & Yes & Yes & No & No & No & Yes \\
\hline Participation & Voluntary & Voluntary & Voluntary & Voluntary & Voluntary & Voluntary & Voluntary \\
\hline $\begin{array}{l}\text { Response } \\
\text { Required }\end{array}$ & Voluntary & Voluntary & Mandatory & Voluntary & Mandatory & Mandatory & Mandatory \\
\hline $\begin{array}{c}\text { Advance } \\
\text { Notification }\end{array}$ & None & $\begin{array}{l}\text { Day-Ahead } \\
\text { Clearing } \\
(\sim 5: 00)\end{array}$ & $\begin{array}{l}\text { Day-Ahead } \\
\text { Clearing } \\
(\sim 5: 00)\end{array}$ & $\begin{array}{l}\text { Day-Ahead } \\
\text { Clearing } \\
(\sim 5: 00)\end{array}$ & $\begin{array}{l}\text { Day-Ahead } \\
\text { Clearing } \\
(\sim 5: 00)\end{array}$ & $\begin{array}{l}\text { Day-Ahead } \\
\text { Clearing } \\
(\sim 5: 00)\end{array}$ & None \\
\hline $\begin{array}{l}\text { Ramp } \\
\text { Period }\end{array}$ & $\begin{array}{l}\text { Resource- } \\
\text { Specific } \\
\text { (Biddable } \\
\text { Parameter) }\end{array}$ & 5 Minutes & 10 Minutes & 5 Minutes & 10 Minutes & $\begin{array}{c}\text { Effectively } \\
\text { Instantaneous }\end{array}$ & - \\
\hline Duration & $\begin{array}{c}\text { As } \\
\text { Scheduled / } \\
\text { Dispatched }\end{array}$ & $\begin{array}{l}\text { As } \\
\text { Scheduled / } \\
\text { Dispatched } \\
\text { with } 1 \text { hour } \\
\text { (Minimum) }\end{array}$ & $\begin{array}{l}\text { As } \\
\text { Scheduled / } \\
\text { Dispatched } \\
\text { with } 1 \text { hour } \\
\text { (Minimum) }\end{array}$ & $\begin{array}{l}\text { As } \\
\text { Scheduled / } \\
\text { Dispatched } \\
\text { with } 1 \text { hour } \\
\text { (Minimum) }\end{array}$ & $\begin{array}{l}\text { As } \\
\text { Scheduled / } \\
\text { Dispatched } \\
\text { with } 1 \text { hour } \\
\text { (Minimum) }\end{array}$ & $\begin{array}{c}\text { As } \\
\text { Scheduled / } \\
\text { Dispatched } \\
\text { with } 1 \text { hour } \\
\text { (Minimum) }\end{array}$ & $\begin{array}{c}\text { As } \\
\text { Scheduled / } \\
\text { Dispatched } \\
\text { with } 4 \text { hours } \\
\text { (Minimum) }\end{array}$ \\
\hline $\begin{array}{c}\text { Telemetry } \\
\text { Requirement }\end{array}$ & No & No & No & Yes & Yes & Yes & No \\
\hline
\end{tabular}

Source: North American Wholesale Electricity DR Program Comparison, 2009 [33]

Three different types of resources can be enrolled in this program:

- Autonomous generators

- Interruptible loads 
- Direct Load Control resources, which can be remotely managed by the System Operator

If a reduction is activated, they must interrupt the committed load, facing penalties if the reduction is unfulfilled. Minimum load packages of $100 \mathrm{~kW}$ must be offered, individually or aggregately.

\subsubsection{California ISO}

Currently, there is only one DR product offered by the California ISO (CAISO): the Participating Load Program. However, a new program called Proxy Demand Response will be offered beginning in 2011 [61]. This program will allow customers to bid demand response services, individually or aggregately, into wholesale Day-Ahead or Real-time markets.

Although only one DR product is offered by the system operator in California, it is important to point out that many customers are providing demand response services, given that there are many different programs offered by their electric utilities, as discussed in section 2.5.3.

\subsection{Participating Load Program [61], [62], [63]}

This program mainly deals with the management of large pumps installed in the State water project. These devices interrupt electricity consumption when required by CAISO in response to their price signal or when there is an electricity shortage.

The program allows customers to participate through price-responsive demand in the Non-Spinning Reserves, Replacement Reserves and Supplemental Energy markets, managed by CAISO. Participants present separate bids for energy and capacity, and the minimum size to participate is $1 \mathrm{MW}$, individually or aggregately. 
An Ancillary Services Certification is compulsory to participate in either the NonSpinning Reserve or Replacement Reserve markets, but it is not required for participation in the Supplemental Energy market.

Customers wishing to participate as Non-Spinning or Replacement Reserve must be able to interrupt their loads within 10 minutes or 60 minutes, respectively, after System Operator notification. Resources participating in Supplemental Energy markets must respond within 60 minutes of the interruption order.

Table 9. Summary of the DR programs offered by the California ISO

\begin{tabular}{|c|c|c|}
\hline \multirow{2}{*}{ Name } & \multicolumn{2}{|c|}{ Participating Load Service } \\
\hline & ENERGY & RESERVE \\
\hline Primary Driver & Economic & Economic \\
\hline Type of Service & Energy & Reserve \\
\hline Minimum size & $1 \mathrm{MW}$ & $1 \mathrm{MW}$ \\
\hline $\begin{array}{l}\text { Aggregation } \\
\text { allowed }\end{array}$ & Yes & Yes \\
\hline Participation & Voluntary & Voluntary \\
\hline Response Required & Mandatory & Mandatory \\
\hline $\begin{array}{l}\text { Advance } \\
\text { Notification }\end{array}$ & $\begin{array}{l}\text { Day-Ahead Market } \\
\text { Clearing }(\sim 1: 00 \text { pm) }\end{array}$ & $\begin{array}{l}\text { Day-Ahead Market } \\
\text { Clearing }(\sim 1: 00 \mathrm{pm})\end{array}$ \\
\hline Ramp Period & 1 Hour & 10 Minutes \\
\hline Duration & $\begin{array}{c}1 \text { hour or resource's } \\
\text { min. run time }\end{array}$ & 2 Hours (Maximum) \\
\hline $\begin{array}{l}\text { Telemetry } \\
\text { Requirement }\end{array}$ & No & Yes \\
\hline
\end{tabular}

Source: North American Wholesale Electricity DR Program Comparison, 2009 [33] 


\subsubsection{DR Programs Offered by Utilities}

Figure 6 shows the evolution that DR programs have experienced in the past two decades $^{8}$. While utilities have been offering customers the possibility of reducing their electricity bill in exchange for reducing their power demand at certain times for many years, 2002 marked the beginning of a clear upward trend. In 2007, a peak load reduction of more than $30,000 \mathrm{MW}$ was achieved through these programs.

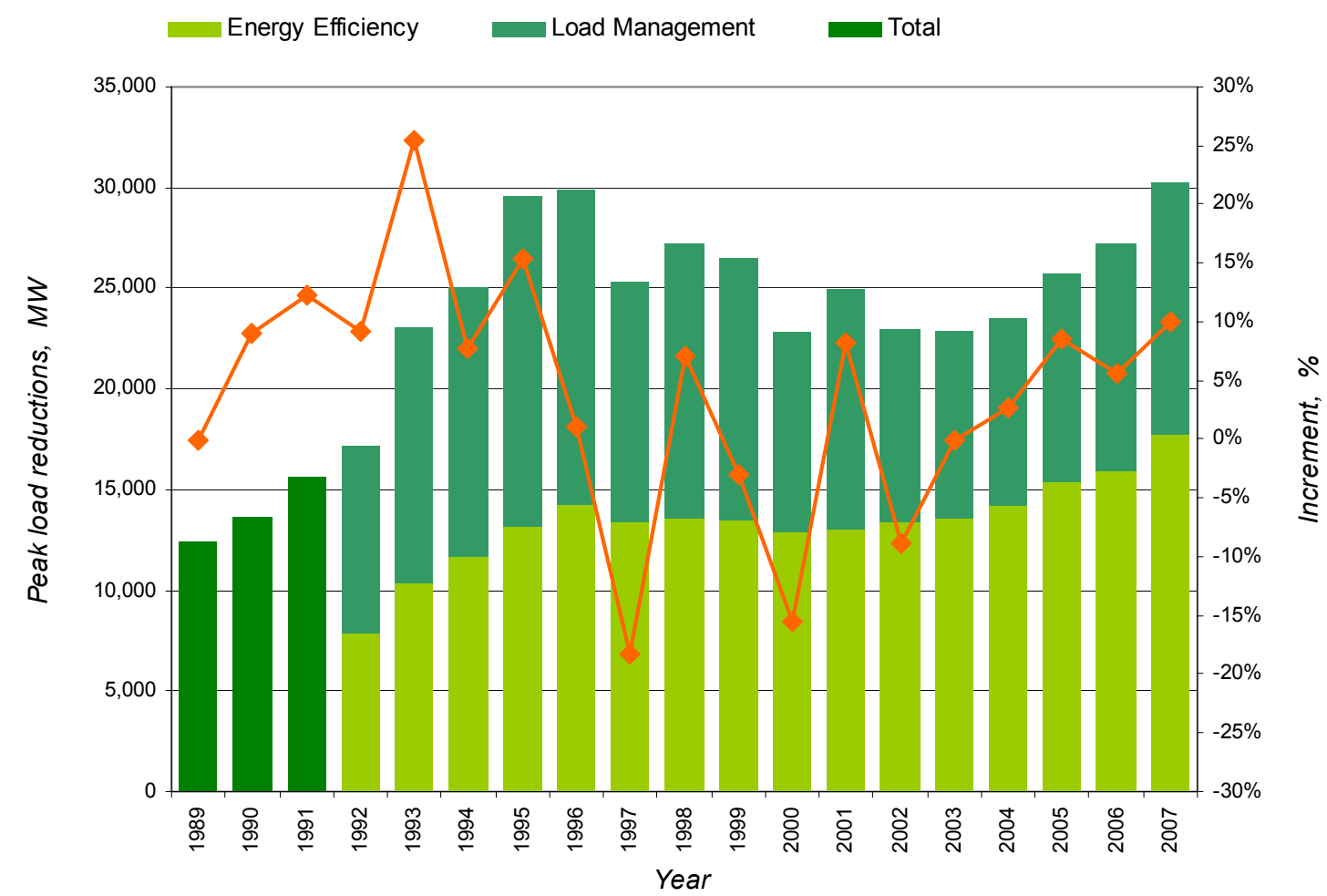

Figure 6. Electric utility demand-side management programs in the U.S. (1989-2007) The chart distinguishes between energy efficiency and load management actions. Energy Efficiency refers to programs focused on reducing the energy used by customers, typically without affecting the services provided. On the other hand, Load Management actions are related to temporary reductions at certain hours when electricity is more expensive or an emergency event happens. Little impact on the process is admissible.

${ }^{8}$ Charts for this section have been elaborated with information obtained from official energy statistics published by the U.S. Government (http://www.eia.doe.gov) 
DR programs offered by utilities have meant significant energy and economic savings, as shown in Figure 7. According to the most recently published data by the U.S. Department of Energy (2007), savings of around 70,000 GWh (out of a total annual consumption of 4.15 million GWh nationwide ${ }^{9}$ ) were achieved thanks to the different DR programs offered by utilities.

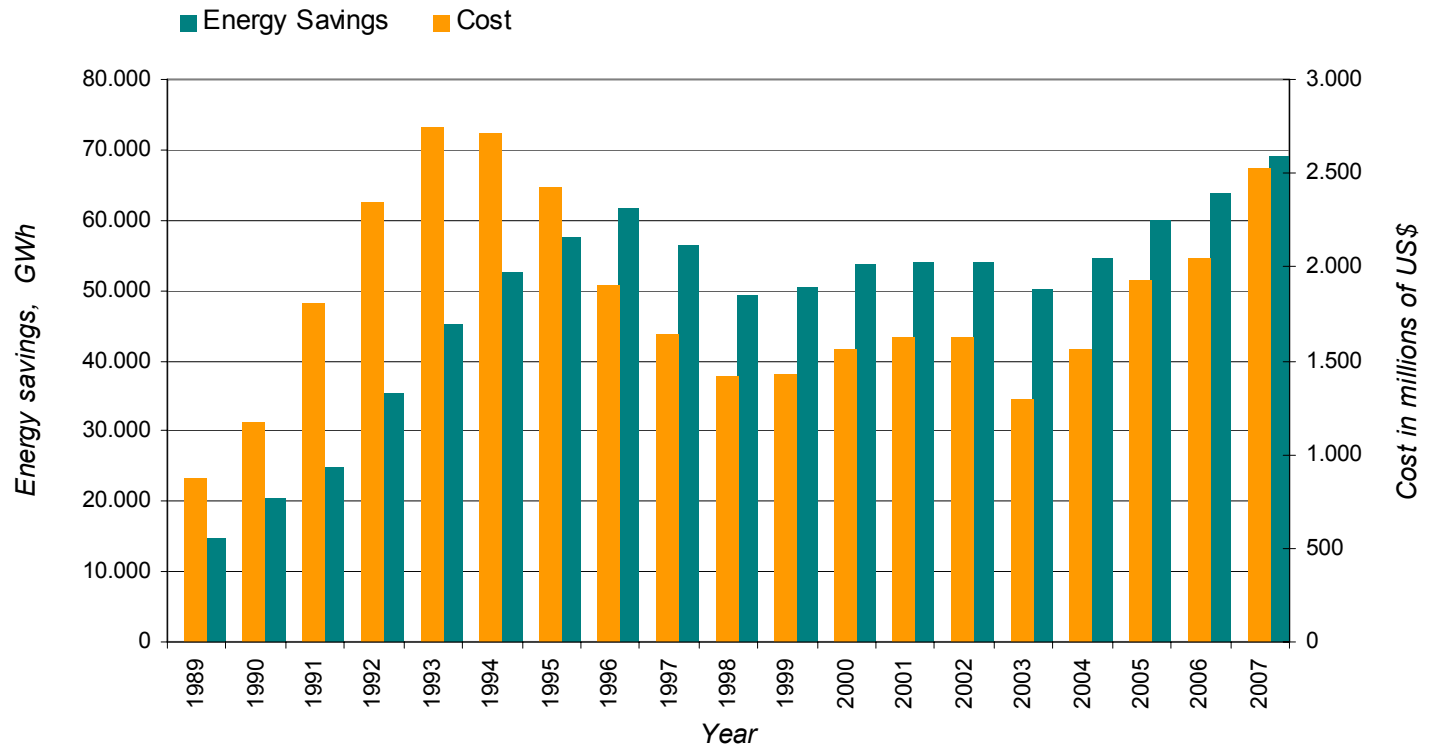

Figure 7. Savings obtained through electric utility DR programs in the U.S. (1989-2007)

According to the "Draft for Comment of the National Action Plan on Demand Response" [14], the states where the most active utilities in DR issues work are shown in Figure 8. This section describes the main characteristics of some of the most representative DR programs offered by such utilities.

9 Official statistics from the U.S. Department of Energy (http://www.eia.doe.gov) 


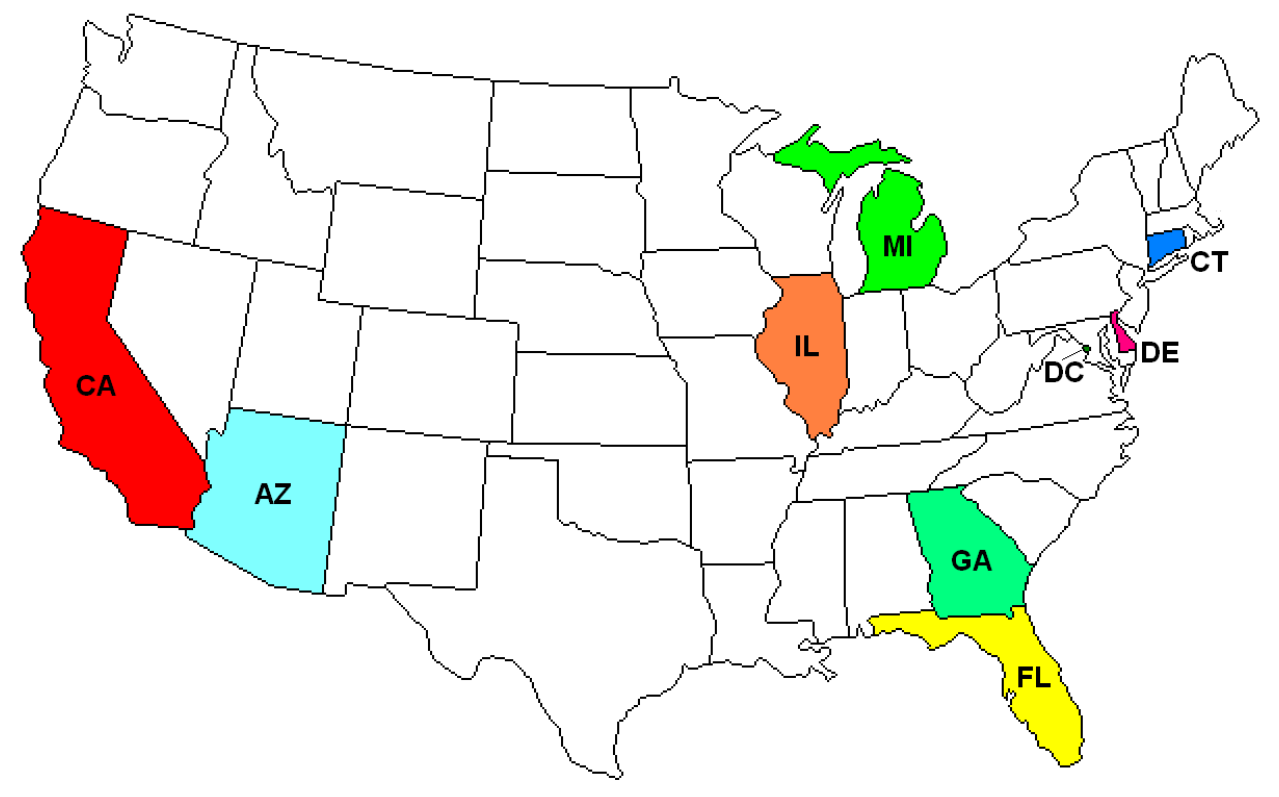

Figure 8. Map of studied states where DR programs have been developed by utilities

\subsubsection{Arizona}

The hot summer weather in Arizona leads to the intensive use of domestic air conditioning devices. For that reason, different time-of-use rates are offered to residential consumers (they are used by about the $40 \%$ of households) by the main utilities in the State, the Arizona Public Service Company and the Salt River Project [14].

\subsection{The Arizona Public Service Company}

- $\quad$ APS Peak Solutions ${ }^{\text {SM }}$. The Arizona Public Service Company (APS) gives customers the opportunity to participate in APS Peak Solutions, which is a direct load control DR program, launched in June 2010 and focused on commercial and industrial customers in the metropolitan Phoenix and Yuma areas. Air conditioning devices are directly and remotely controlled during peak demand times by APS. The utility disconnects air conditioning appliances in times of critical electricity demand between 
noon and 8:00 pm, from June through September. Customers receive free installation of a web-programmable thermostat, as well as a payment of $\$ 25$ for enrollment in case of small and medium customers, or an annual check based on demand reduction and energy saved for large customers. Additionally, five TOU tariffs are offered to customers, depending on their monthly consumption. On-peak hour prices (applied from $11: 00$ am to $9: 00 \mathrm{pm}$, Monday to Friday) are $25 \%$ to $35 \%$ higher than the ones applied for off-peak periods ${ }^{10}$.

\subsection{The Salt River Project Power and Water (SPR)}

The Salt River Project Power and Water, the largest provider of power to the Phoenix metropolitan area, offers different programs for residential, commercial and industrial customers. In particular, a few are worth highlighting [64]:

- $\quad$ SRP-M Power® program. Power meters are installed to monitor detailed consumption in residential appliances, so customers can track when and how they are consuming energy. More than 80,000 customers are currently enrolled, generating savings of approximately $12 \%$ in total consumption in this sector.

- $\quad$ SRP EZ-3 ${ }^{\mathrm{TM}}$ for residential customers only and SRP Time-of-Use ${ }^{\mathrm{TM}}$ for residential and commercial customers. These are two types of Time-of use tariffs; prices are higher during on-peak periods and lower during offpeak periods.

- SRP PowerPartner ${ }^{\mathrm{TM}}$ Demand Response program. This program, launched in the summer of 2009 , allows participants to voluntarily reduce

\footnotetext{
${ }^{10}$ This information has been obtained from http://www.aps.com
} 
their electricity consumption (minimum $100 \mathrm{~kW}$ with 10 minutes notice) during on-peak periods or when wholesale electricity prices are high. Managed by Enernoc Inc. as a Demand Response Provider, enrollees can be called up to 15 times per year, for a maximum of 60 hours of interruption. The energy reduction must be maintained from 1-4 hours, depending on the type of event. The expected annual reduction is about $50 \mathrm{MW}$. Events can occur on weekdays between noon and 8:00 p.m. in summer, and between 5:00 am and 9:00 pm in winter. Customers receive a payment for their participation, but penalties are not applied if a reduction is not fulfilled [65].

\subsubsection{California}

California has been one of the most active states on DR issues since 1978, when the California Energy Commission first developed time-of-use tariffs for large commercial and industrial customers [14]. The most significant DR programs offered by different utilities in the state include the following:

\subsection{Southern California Edison (SCE)}

This utility is one of the largest in the U.S., offering a wide variety of DR programs $^{11}$ :

- Agricultural and Pumping Interruptible Program. Designed for customers with at least $37 \mathrm{~kW}(50 \mathrm{HP})$ connected to the grid, this program provides price discounts to customers in exchange for programmed load interruptions. The maximum duration of an event is six hours.

\footnotetext{
${ }^{11}$ The information about DR programs offered by SCE has been extracted from its official website: http://www.sce.com/drp
} 
- Automated Demand Response. Individual or aggregated customers with demands of at least $200 \mathrm{~kW}$ can participate in this program, which uses a remotely controlled system to disconnect certain predefined loads during peak periods. This system receives price signals from SCE via the internet and switches off the load when prices are high.

- Time-of-Use Base Interruptible Program. Similar to the previous program, this is designed for customers whose individual or aggregated demand is $200 \mathrm{~kW}$ or higher. Customers receive a monthly discount credit based on the difference between their average peak period demand for each month and the residual amount of power that customers consider indispensable for the proper operation of their facilities.

- Capacity Bidding Program. This program offers payments to customers willing to disconnect some loads (lighting, HVAC, escalators, elevators, pumps) when required by SCE during the summer. No event can last more than 24 hours. Moreover, customers are allowed to change the notification timing and the interruption period every month. Participants can receive a payment that varies between $\$ 3$ and $\$ 24$ per $\mathrm{kW}$ and month, depending on the month when the service is required and the interruption period (payments in August for periods 2-6 and 4-8 are the highest).

- Critical Peak Pricing. Customers whose connected power is $200 \mathrm{~kW}$ or higher can participate in this program, which gives discounts to participants who voluntarily interrupt, shift usage to off-periods or reduce their loads during peak periods, as a response to an SCE call. The 
service can be activated 9-15 times every summer due to extreme weather conditions.

- Demand Bidding Program. Participants present bids to reduce their load from noon to $8: 00 \mathrm{pm}$ on weekdays, and these may be accepted or declined the day prior to the load reduction. Customers with $200 \mathrm{~kW}$ or more of connected power, or aggregations of up to 25 customers with the same total amount of power, are allowed to participate in this program. Payments are on the order of $\$ 0.50$ per $\mathrm{kWh}$ of real power reduction. Penalties are not applied to customers that do not reduce their committed load, but they do not receive the payment for the service.

- Optional Binding Mandatory Curtailment Program. This program exempts customers from rotating outages ${ }^{12}$ if they are able to reduce at least $15 \%$ of their total load during every rotating outage. There are no other monetary incentives for participating in this program.

- Permanent Load Shifting. This program is based on the use of ice-store technologies. Energy is used during off-peak periods to chill and freeze water, when rates are lower. The stored ice is used later during on-peak periods for air conditioning production.

- Summer Discount Plan. This program allows the utility to remotely disconnect the customer's central air conditioning compressor up to 15 times during the summer, for up to six hours per day. Depending on the

${ }^{12}$ According to the SCE definition, "A rotating outage is a controlled electric outage that lasts approximately one hour for a group of circuits. Rotating outages are used during electric system emergency conditions to avoid widespread or uncontrolled blackouts. Each SCE customer is assigned a rotating outage group which can change, without notice, at any time". Source: http://www.sce.com 
scheduled actions, a customer can receive a discount between $\$ 0.05$ and $\$ 0.36$ a day.

- Real-Time Pricing (RTP-2). Customers with maximum power higher than $500 \mathrm{~kW}$ can participate in this program. It uses variable rates that depend on external temperatures in downtown Los Angeles, obtained the day before. Customers receive daily price quotes for the following day, so they can voluntarily reduce their demand when prices are higher.

- Pumping and Agricultural Real-Time Pricing. Customers that use $70 \%$ or more of their electricity for general agricultural purposes, or for general water/sewage pumping, are allowed to participate in this program, unless they are expected to exceed a demand of $500 \mathrm{~kW}$. Prices are calculated hourly, according to time of day, season and temperature. Similarly to RTP-2, customers receive daily prices for the following day, so they are able to adjust their demand to prices.

- Scheduled Load Reduction Program. Customers enrolled in this program must agree to energy reductions of at least $15 \%$ of total energy demanded during the event, with a minimum reduction of $85 \mathrm{~kW}$. A credit of $\$ 0.10$ per $\mathrm{kWh}$ can be obtained by participants, whose maximum power must be $100 \mathrm{~kW}$ or higher.

\subsection{San Diego Gas and Electric}

San Diego Gas \& Electric (SDGE) is a regulated public utility that provides service in San Diego and southern Orange County ${ }^{13}$. A number of DR programs offered by this utility are described below:

\footnotetext{
${ }^{13}$ The information included in this section has been obtained from http://www.sdge.com
} 
- Summer Saver Program. Activated from May-October, this program is based on the installation of an automatic control device at the entrance of the air conditioning unit, which remotely disconnects it when demand peaks occur. The installation of this control device is free for the customer. The program may be activated up to 15 times a season. Participants can choose between $50 \%$ or $100 \%$ cycling options. This second option implies longer disconnections, so the obtained bonus is also more significant.

- Critical Peak Price Program. Designed for customers who use more than $20 \mathrm{~kW}$, this program is based on a TOU tariff which is much higher during peak periods (usually on hot summer days), so that customers have the opportunity to reduce their power demand during such peak hours.

- Critical Peak Price Program for Emergencies. Participants can offer any amount of power reduction (there is no a minimum amount), but customers who can immediately reduce their load have preference. However, only those with more than $20 \mathrm{~kW}$ of contracted power can participate. Committed power must be interrupted no later than 30 minutes after the notification. In exchange, customers receive a rate discount on high prices during alert periods.

- Base Interruptible Program. This program consists of two different options offered to customers who reduce load demand when required by SDGE. At least $100 \mathrm{~kW}$ or $15 \%$ of the monthly average peak demand must be reduced. Participants can obtain $\$ 7 / \mathrm{kW}$ a month in option A (30 minutes of advance notification) or $\$ 3 / \mathrm{kW}$ in option B (3 hours of advance notification). Reductions are required only if an emergency occurs, so the 
bonus could be obtained even if no interruption is activated. On the other hand, penalties are applied when participants do not fulfill the agreed upon reduction $(\$ 4.50 / \mathrm{kWh}$ exceeded in option $\mathrm{A}$ and $\$ 1.88 / \mathrm{kWh}$ exceeded in option B).

- Capacity Bidding Program. Customers who sign a Capacity Bidding Contract have to commit, individually or aggregately, to at least a $20 \mathrm{~kW}$ reduction of power if necessary. Participants receive a capacity payment, as well as an additional energy payment if a reduction is activated. There are two available options for notification times: the Day-ahead option (the notification is produced by 3:00 p.m. on the day prior to the interruption) and Day-of option (the notification is produced at least 2 hours prior to the event).

\subsection{Pacific Gas and Electric (PGE)}

Two programs are offered by this utility, whose territory extends around the San Francisco area. Their main characteristics are indicated below:

- Peak Day Pricing Program. At the moment, only large customers with more than $200 \mathrm{~kW}$ of contracted power can participate in this program. However, it is expected that smaller customers (up to $200 \mathrm{~kW}$ ) will be incorporated by November 2011. Currently, this program is based on a TOU tariff that reduces energy prices most of time while raising it significantly during peak periods, so that customers who are able to shift their loads can significantly reduce their electricity bill.

- $\quad$ SmartAC ${ }^{\mathrm{TM}}$ Program. This program is based on the remote management of temperature settings on HVAC devices. A control system is installed free of charge by PGE in the customer's facilities; this receives a signal 
which modifies the thermostat setting of HVAC devices when required by the utility. Energy consumption is thus reduced when load is increased in the System.

\subsubsection{Connecticut}

Connecticut is currently working to identify all available resources for energy efficiency and demand response programs. New plans are being developed by the electric distribution companies in order to specify future demand-side products. Some of them have been tested recently. For instance, Connecticut Light and Power carried out a pilot program for demand response in the summer of 2009 in order to determine the effectiveness of demand reductions during peak periods [14].

\subsection{Connecticut Light and Power (CLP)}

This utility offers two Load Management programs for medium and large consumers $^{14}$. One is oriented to favor the distributed generation that residential, commercial and industrial customers may produce themselves. The second one is a typical DR program to reduce power during peak periods:

- Demand Reduction. This program, which has become very popular in recent times, is offered to industrial and commercial customers willing to reduce their power demand during peak periods. Participants are monitored and controlled in real time to automatically control a sequence of events, predetermined by CLP, during the peak period. Once CLP verifies the fulfillment of these sequences (after the measures are completed), participants receive an incentive payment.

\footnotetext{
${ }^{14}$ The information included in this sections has been obtained from: http://www.cl-p.com
} 


\subsubsection{Delaware}

The state of Delaware is an example of how the government is fostering the development of new DR programs among utilities in order to take advantage of available demand resources. For example, since 2006, the utility Delmarva Power and Light ${ }^{15}$ has been carrying out a project to forecast the required electricity resources, including DR, to cover the demand in this state for the next 10 years [14]. These programs are currently being studied.

\subsubsection{Florida}

DR initiatives have been implemented since the 1990s in Florida, basically under the management of two companies: Gulf Power and Florida Power and Light. Other initiatives have also recently been launched by Progress Energy.

\subsection{Gulf Power Company [14]}

Since 1990, the Gulf Power Company has offered residential customers in Florida an interesting program, which about 8,000 customers have used so far. It is based on an automatic system that manages devices such as air conditioning, space heaters, water heaters or swimming pool pumps, disconnecting them during peak hours when prices are very high (almost four times higher than in other periods). Customers pay a small fee of about $\$ 5$ a month, but they can achieve savings of about $15 \%$ in the total electricity bill.

\footnotetext{
${ }^{15}$ Delmarva Power and Light provides electricity to the peninsula of Delmarva, occupied by Delaware and portions of Maryland and Virginia
} 


\subsection{Florida Power and Light Company (FPL) ${ }^{16}$}

- On Call Program. The Florida Power and Light Company offers households the On Call Program, one of the largest DR initiatives in the U.S. (about $973 \mathrm{MW}$ had been provided by means of this program at the end of 2008 , with more than 780,000 customers) [14]. When necessary, participants let FPL interrupt the air conditioning service during short periods of time. The program runs from April to October (usually from 3:00 pm to 5:00 pm) when the electricity demand is higher, so customers are eligible to receive a credit for each of the seven months when the program is active.

- Commercial Demand Reduction Program. This program is used to achieve demand reductions during capacity shortfalls or system emergencies. Customers receive a monthly credit if they allow FLP to reduce their electricity loads by a predetermined amount.

- Business Custom Incentive. This is a "customized" program that assesses the ability of customers to reduce at least $25 \mathrm{~kW}$ of electricity during the summer peak demand, between the hours of 3:00 pm and 6:00 pm from April to October. Participants receive an incentive in exchange for their participation.

\subsection{Progress Energy (PE) ${ }^{17}$}

- Energywise Home ${ }^{\mathrm{TM}}$ program. Customers enrolled in this program allow PE to install a control instrument which disconnects devices such as pool

\footnotetext{
${ }^{16}$ The information included in this section has been obtained from http://www.flp.com

17 The information included in this section has been obtained from http://www.progressenergy.com
} 
pumps, water heaters or HVAC central units during peak periods. There are two possible contracts: the Year-round program and the Winter-only program (from November to March). Monthly credits from $\$ 11$ to $\$ 14$ can be obtained.

\subsection{Tampa Electric Company (TECO) ${ }^{18}$}

- Load Management Program. This program offers customers the possibility of receiving a credit if they allow TECO to install a control instrument that disconnects devices such as air conditioning or other specialized equipment during critical energy-use periods. This control instrument may or may not be remotely managed by TECO, depending on the contract. There are two possible ways to enroll: the Cyclic Option, from April-October, and the Continuous Option, active for the whole year. Payments vary between from $\$ 2.50$ per $\mathrm{kW}$ for the first option, and $\$ 3$ per $\mathrm{kW}$ for the second one.

\subsubsection{Georgia}

Since 1995, Georgia Power has managed the largest program for large commercial and industrial consumers in real time in the U.S., and it has had the skill to combine risk management products with demand response in this program.

\footnotetext{
${ }^{18}$ The information included in this section has been obtained from: http://www.tampaelectric.com
} 


\subsection{Georgia Power ${ }^{19}$}

Currently, this utility is able to achieve reductions of up to $4000 \mathrm{MW}$ during peak hours, supplied by about 1,200 consumers. These consumers receive information about the prices that electricity will cost on the next day, so they have the possibility to choose the most suitable products for them out of a wide range of options, depending on the risk they are willing to assume. Reductions range from $4 \%$ for day-ahead participants and $10 \%$ for hour-ahead ones on a normal day. However, these reductions could rise to $7 \%$ and $30 \%$ for day-ahead and hour-ahead customers, respectively, on high price days [14]. Moreover, the utility offers some interruptible programs for different types of customers, as detailed below:

- Power Credit Program. Designed for residential customers, this program allows Georgia Power to remotely control participants' air conditioning devices by activating a switch connected to the air conditioning. In this way, the AC can be disconnected when the electricity demand is very high (usually during summer peaks). Customers receive a payment of $\$ 20$ for their participation. Additionally, another $\$ 2$ will be paid out each time the program is activated.

- Demand Plus Energy Credit Rider Schedule. Applicable to customers who can reduce at least $200 \mathrm{~kW}$ of their load demand, this program offers credits for both energy (varying from $\$ 0.50$ to $\$ 1.00$ per $k W h$ ) and demand (from $\$ 3.50$ to $\$ 6.25$ per $\mathrm{kW}$, depending on the type of interruption). There are three types of products, which differ according to the maximum duration of events a year (100, 50 or 25 interruptible hours). Penalties are applied if any interruption is not fulfilled. Interruptions are

\footnotetext{
${ }^{19}$ The information included in this section has been obtained from: http://www.georgiapower.com
} 
usually activated during the summer period, from June-September, but they can be activated at any time.

- Daily Energy Credit Rider Schedule. Customers who have an average historic demand equal to or higher than $500 \mathrm{~kW}$ between 2:00 pm and 7:00 pm on summer weekdays are eligible to participate in this program. The customer receives interruption orders together with a proposed credit for each one. There is no limit on the number of orders during the year, so the customer may be asked to voluntarily participate at any time. Furthermore, a penalty equal to two times the credit that the customer would have received if they had fulfilled the interruption is applied when an order is accepted and not satisfied.

\subsubsection{Illinois}

The case of Illinois clearly indicates how residential customers can attain significant savings if real-time prices are offered to them. Real-time contracts were launched for the first time in 2006. New meters were installed in households, the cost of which was charged to all the residential customers, even if they did not participate in the program.

At the beginning of 2009 , almost 9,000 customers were enrolled in some program offered by the two main Illinois utilities, Commonwealth Edison and Ameren, garnering savings of $2.5 \%$ and $9 \%$, respectively [14]. 


\subsection{Commonwealth Edison (ComEd)}

At the moment, this utility offers two load response programs: the Voluntary Load Response Program and the Capacity-Based Load Response Program, whose main characteristics are detailed below ${ }^{20}$.

- Voluntary Load Response Program. This is the most popular program offered by ComEd, available to commercial customers who can reduce at least $10 \mathrm{~kW}$ when required. Reductions are assessed by comparing the measured load curve with a theoretical shape, obtained from the curve registered over the five previous workdays. On average, participants are paid $\$ 0.25$ per kWh reduced, depending on the hourly energy market, but a minimum payment for participating is not guaranteed. The duration of interruptions is usually between two and eight hours, and customers are notified at least one hour in advance. Penalties are not applied if interruptions are not fulfilled.

- Capacity-Based Load Response Program. This program is offered to nonresidential customers able to provide at least $100 \mathrm{~kW}$ reductions when requested by ComEd. The program period is from June 1 to September 30 , and interruptions can last two to eight hours. Customers receive an annual market-based compensation for energy they do not consume, and penalties are applied when an interruption is not fulfilled. The program offers two different options: the Firm Service Level Defined Option, wherein participants are able to reduce loads to specified levels, and the Guaranteed Load Drop Defined Option, when customers have the ability to reduce load by a specified amount of power. Participants can also

\footnotetext{
${ }^{20}$ The information included in this section has been obtained from: http://www.comed.com
} 
choose between short advance notice time (30 minutes) and a long notice time (ninety minutes), which does not affect the received payment.

\subsection{Ameren (AIU)}

Ameren Illinois Utilities, formed by the three utilities AmerenCIPS, AmerenCILCO, and AmerenIP, delivers electricity in central and southern Illinois, and it give customers the opportunity to participate in the following program ${ }^{21}$ :

- E-Smart ${ }^{\mathrm{TM}}$ Programmable Thermostat. This program is offered to residential and non-residential customers willing to allow AIU to remotely manage their central air conditioner, turning it off during peak periods. AIU installs a free, internet-enabled thermostat, which can operate from 1:00 pm to 5:00 pm on weekdays during the summer. There are no additional payments, besides saving energy when electricity is more expensive.

\subsubsection{Michigan}

The state of Michigan has been working since 2007 to reduce the peak load in total electricity demand, although some programs, such as the interruptible air conditioning program (IAC) offered by Detroit Edison, have been operative for over 20 years. By 2030, different load management, demand response and interruptible load programs for residential and small commercial customers are expected to reduce the peak load by almost $10 \%[14]$.

\footnotetext{
${ }^{21}$ The information included in this section has been obtained from: http://www.actonenergy.com and http://www.ameren.com
} 


\subsection{Detroit Edison Energy Company ${ }^{22}$}

- CoolCurrents ${ }^{\mathrm{TM}}$. This program is based on a direct payment to customers of $\$ 0.02$ per interruption, which the utility controls by remotely disconnecting their air conditioning units. The mean interruptible power is about $0.85 \mathrm{~kW}$ per unit, and the duration of interruptions is 15 minutes. This can also be utilized as capacity reserve since it may be available in only 10 minutes [14]. There is a monthly service charge of $\$ 1.95$ from June to October, but this program provides savings up to $20 \%$ off a normal air conditioning bill.

\subsubsection{Washington D.C. ${ }^{23}$}

\subsection{Potomac Electric Power Company (Pepco)}

Pepco provides electric service to residential and commercial customers in Washington D.C. and part of Maryland. The pilot program, PowerCentsDC ${ }^{\mathrm{TM}}$ (described below), was launched in July 2008.

- PowerCentsDC ${ }^{\mathrm{TM}}$ Pilot Program. The aim of this program is to inform participants about high electricity prices so they can reduce their consumption and save energy and money. There are three different contractual options: The Critical Peak Pricing Option, the Critical Peak Rebate options, and the Hourly Pricing Option. A smart meter is installed in each customer's facilities, which registers when electricity is used and informs the customer about prices of electricity for different periods of time, depending on the contractual option selected. Additionally, a free

\footnotetext{
${ }^{22}$ The information included in this sections has been obtained from: http://www.dteenergy.com

${ }^{23}$ The information included in this section has been obtained from: http://www.pepco.com
} 
smart thermostat to manage the air conditioning unit is installed with customers' consent.

\subsection{Demand Response in Europe}

\subsubsection{Power Markets in Europe}

The European power market can be divided into eight regional markets, most of which are physically interconnected [24], with different rules and technical standards [66]:

- Central Western Europe, including Germany, Netherlands, France, Belgium, Switzerland and Austria

- Northern Europe, which includes Sweden, Finland, Denmark and Norway

- Apennine Peninsula (Italy)

- Iberian Peninsula, including Spain and Portugal

- Central Eastern Europe, comprising Poland, the Czech Republic, Hungary and Slovakia

- British Isles, formed by the United Kingdom and Ireland

- South Eastern Europe, including Slovenia, Greece, Bulgaria, Romania, Croatia, Serbia, Albania, Macedonia and Montenegro

- Baltics, composed by Estonia, Lithuania and Latvia.

Some years ago, a deregulation process started in EU energy markets, which is expected to culminate in the creation of a single European electricity market [67]. As stated in Directive 96/92/EC, published in December 2006, the activities of generation, transmission, distribution and energy trading have been separated. Competition has been achieved in generation and trading, while activities related to the ownership and 
management of the grid (transmission and distribution) are regulated and function as monopolies [68].

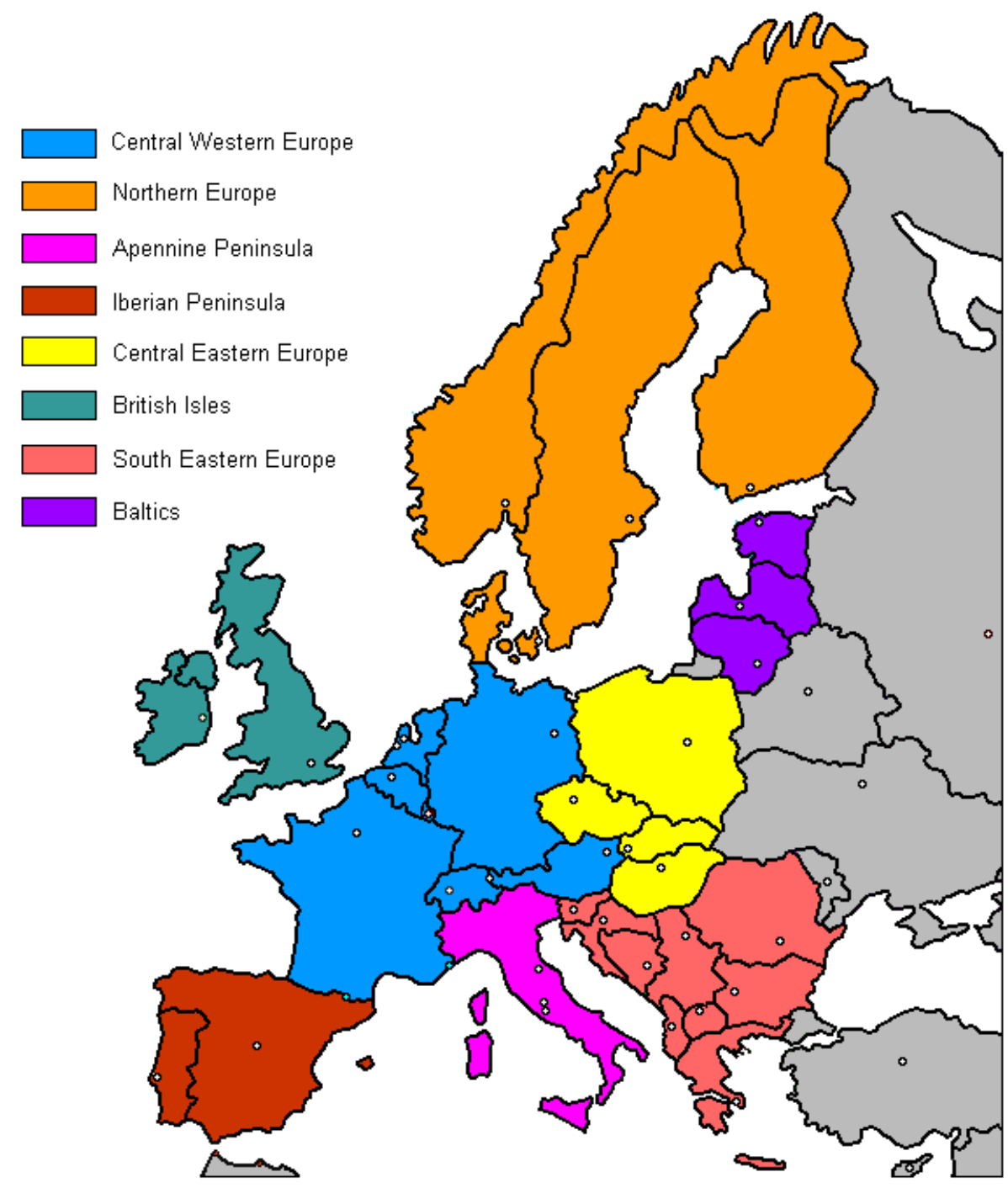

Figure 9. Regional power markets in Europe

Europe is divided into eight power markets, most of which are physically interconnected. Some of these countries are part of the European Union, which is currently composed of 27 Member States: Austria, Belgium, Bulgaria, Cyprus, the Czech Republic, Denmark, Estonia, Finland, France, Germany, Greece, Hungary, Ireland, Italy, Latvia, Lithuania, Luxembourg, Malta, the Netherlands, Poland, Portugal, Romania, Slovakia, Slovenia, Spain, Sweden and the United Kingdom (http://europa.eu)

Different regional initiatives have been launched by the European Commission [67], and some regional markets involving different countries, such as the MIBEL 
(Iberian Electricity Market) for Spain and Portugal or the Nordpool for Norway, Denmark, Sweden and Finland, are currently running. The EU-27 consumed 304,490 GWh in $2008^{24}$

\subsubsection{Demand Response Programs in Europe}

Due to the inexistence of a single European energy market, a joint DR action plan has not been designed for Europe as a whole. Thus, programs developed within EU Member States strongly depend on the initiative of each country and its particular regulation. However, concern has grown with regard to demand participation issues in recent years, and different initiatives have been carried out. One example is the research project EU-DEEP ${ }^{25}$, funded by the European Commission with the objective of identifying and overcoming barriers that prevent the utilization of Distributed Energy and Demand Response Resources. Utilities covering more than 80 million customers all over Europe were involved [5], [2].

DR is an efficient and effective method to achieve both energy savings and peak power reductions, as stated in the European Commission objectives, which are focused on finding a sustainable, reliable, cost-efficient energy supply [69].

An increment of about $45 \%$ average DR usage in most European countries is predicted by 2020 , as shown in Figure 10 . Nevertheless, this percentage could be increased if new DR programs, as proposed in this dissertation, are developed in different countries to take advantage of customers' flexibility, since most existing experiences consist only of interruptible programs, and a significant number of European countries are not taking DR into account for their system plans [24].

\footnotetext{
${ }^{24}$ This information has been obtained from the European Commission Statistics Service. http://ec.europa.eu/eurostat

${ }^{25}$ Some of the results obtained for this dissertation were achieved in the framework of this project
} 


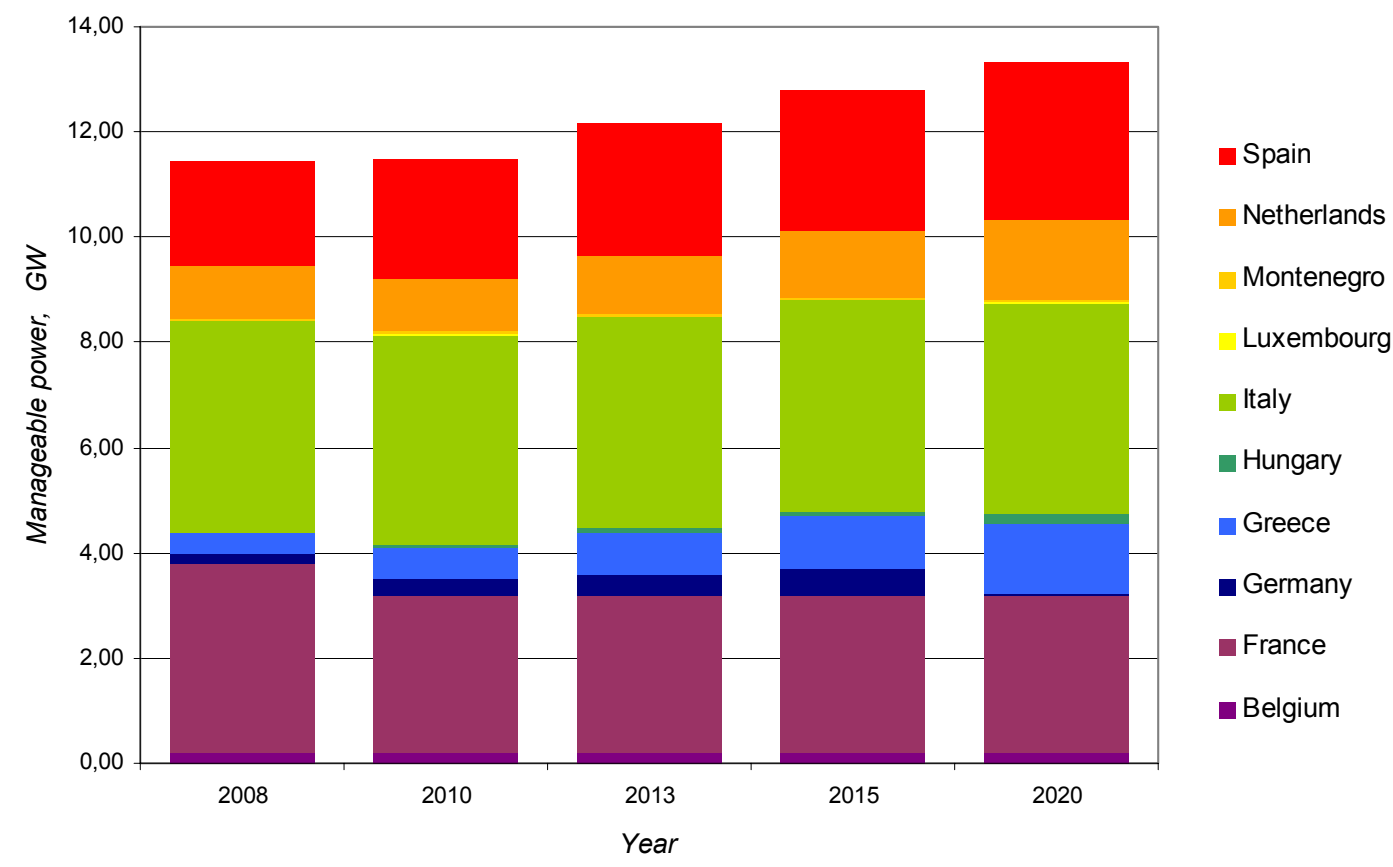

Figure 10. Demand response forecast in UCTE countries from 2008 to 2020 Using previsions found in [24], this figure shows the evolution of manageable power due to demand response in UCTE ${ }^{26}$ countries in Europe up to the year 2020. An increment in DR potential is expected for all the countries except for Germany.

At present, few DR programs are available in European markets; only TOU tariffs and a few more sophisticated programs such as the interruptibility program in Spain or Norway are currently being used. Some of the most representative DR programs in different European countries, as well as some pilot programs recently carried out in some countries to evaluate DR potential, are explained in the following sections.

\subsubsection{Sweden}

Demand side is practically uninvolved in regulating the power market in Sweden. As a symbolic presence, the Swedish TSO, Svenska Kraftnät (SK), arranges auctions to

${ }^{26}$ The UCTE (Union for the Co-ordination of Transmission of Electricity) is an organism aimed to coordinate the operation and development of the electricity transmission grid for the Continental European synchronously operated transmission grid. http://www.ucte.org 
acquire demand resources from industrial customers, which are used as fast active disturbance reserves [70]. In 2008, 90 MW were contracted by SK, 53\% of which were available within 15 minutes, and the rest were ready to be used in half an hour [71].

\subsubsection{Finland}

In Finland, the Finnish TSO Fingrid acquires demand resources by signing annual bilateral contracts with industrial customers; these are used as frequency controlled and fast active disturbance reserves [24], [70]. Finnish Industry is estimated to have a technical DR potential of about $1280 \mathrm{MW}$ ( $9 \%$ of the peak demand in Finland), $35 \%$ of which is currently being used by Fingrid when prices are higher than $300 € / \mathrm{MWh}$ $[70]$.

Typical customers offering demand resources in Finland comprise the metal industry (iron and steel industry and metallurgy), the forest industry and the chemical industry, with a minimum offer of $15 \mathrm{MW}$ to be reduced for at least three hours. Disconnections can be performed either manually (with 15 minutes advance notice) or automatically by means of a frequency relay [71].

\subsubsection{Netherlands}

The Dutch Ministry of Economic Affairs has estimated the DR potential in the wholesale sector to be about $1700 \mathrm{MW}$ (20\% of total peak demand), $58 \%$ of which is currently being utilized. Within this $58 \%$ (about $1000 \mathrm{MW}$ ), only $35 \%$ corresponds to power reductions, while the rest is contracted capacity [70]. About $70 \%$ of the total DR potential could be offered by the industrial sector and the rest by the commercial sector (24\% would correspond to greenhouse farming) and households. However, demand response programs in the retail sector are difficult to run due to the lack of suitable metering and communications systems. 


\subsubsection{France}

The largest utility in France, Électricité de France (EDF), offers an interesting TOU program called Tempo Tariff, used by around 350,000 households and more than 100,000 small business customers [24].

This program, available for customers with a minimum contracted power of 9 $\mathrm{kVA}$, is based on different prices for energy according to the day and the hour of utilization. There are three different color-coded prices throughout the year (blue, white and red, where blue is the cheapest and red is the most expensive), and each color is assigned to certain hours on a daily basis. This information is published every day at 5:00 pm. Because customers are informed daily about the next day's pricing regimen, they can adapt their load curve to reduce the consumption during peak hours. Over the course of a year, there are 22 red days and 43 white ones, while the rest are blue. Prices of energy vary between $0.057 € / \mathrm{kWh}$ for blue days during valley hours, and 0.517 $€ /$ Wh for red days during peak hours, giving customers a significant incentive to avoid consumption in the latter case ${ }^{27}$.

\subsubsection{Denmark}

It is estimated that industry is able to contribute about $380 \mathrm{MW}$ of $\mathrm{DR}$, equivalent to about $7 \%$ of the total peak demand in Denmark [70].

Danish customers consuming more than 100,000 kWh a year (together representing about half of the total electricity demand nationwide) are provided with interval meters, so they can choose when to consume electricity depending on the spot market price. Nevertheless, only a few customers actually exploit this possibility at the moment [72]. Moreover, TOU tariffs are offered to customers wishing to take advantage

\footnotetext{
${ }^{27}$ http://bleuciel.edf.com
} 
of different prices during the day. Such tariffs offer peak prices which are about 1.75 times higher than during the valley.

Regarding demand resources in the residential sector, a pilot program performed in 2004 demonstrated a potential reduction of $5 \mathrm{~kW}$ per household. That means that if $50 \%$ of all households in Denmark (about 125,000 with electric heating devices) participated in any DR program, a reduction of $260 \mathrm{MW}$ would be obtained, assuming an $80 \%$ rate of effectiveness [72].

\subsubsection{Norway}

The Norwegian TSO Statnett is currently offering an interruptible tariff to customers willing to drastically reduce their energy supply when required by the system operator. Depending on the advance notification time and the duration of the interruption, there are three possible modalities: 15 minutes advance notification with no limitation on the duration of the interruption and a reduction of $5 \%$ of the load (mode 1 ); two hours advance notification with no limitation on the duration of the interruption and a reduction of $25 \%$ of the load (mode 2); and 15 minutes advance notification with a twohour limit on the duration of the interruption and a reduction of $75 \%$ of load (mode 3 ). Interruptibility is set using a baseline calculated from the past five years load curve, so that hourly measurements are registered and sent to Statnett to verify that interruptions have been successfully fulfilled. Current prices for interruptibility are 2.75, 10.83 and $32.63 €$ per $\mathrm{kW}$ reduced for modes 1,2 and 3 respectively [73].

Besides this interruptibility program, Statnett operates a Regulating Capacity Options Market, where demand resources can bid together with generators, in order to acquire reserves for disturbances and balancing purposes. Some large industrial customers participate by offering about $1480 \mathrm{MW}$, or about $6 \%$ of the total peak demand 
in the country. The total DR potential in Norway is estimated to be about $14000 \mathrm{GWh}$ a year, which would be activated when the market prices are higher than $70 € / \mathrm{MWh}[70]$.

With regards to the commercial sector, pilot studies showed that $4.5 \mathrm{MW}$ could be reduced by using DR, generating savings of around 15\% [24].

\subsubsection{United Kingdom}

Different DR programs, including TOU tariffs and interruptible contracts, have been offered to customers in the UK for quite some time [24]. Among the first, Economy 7 and Economy 10 tariffs $^{28}$ allows customers to consume cheaper energy for 7 or 10 hours a day, respectively, so they can adapt their load curve to take advantage of lower prices during valley periods. Customers with interruptible contracts wishing to participate as a demand resource in the British market can do so by means of one of the following programs [74]:

- Short Term Operating Reserve: Activated in 2007 [75], this program caters to customers able to reduce at least $3 \mathrm{MW}$, individually or aggregately (aggregation has only recently been allowed), within 240 minutes of the launch of the order reduction. Additionally, participants must be willing to maintain an energy reduction for a minimum of two hours. Reductions can take place at least three times a week. Customers are paid for both availability and utilization. A typical workday includes two availability periods from $7: 30$ am to $2: 00 \mathrm{pm}$, and from $4: 00 \mathrm{pm}$ to $9: 30$ pm.

- Fast Reserve (FR): Participants must be able to deliver a minimum of 50 MW within two minutes of notification, maintaining the reduction for at

\footnotetext{
${ }^{28}$ http://www.uswitch.com
} 
least 15 minutes. Participants receive annual payments for both availability (€/h) and utilization (€/MWh).

- Firm Frequency Response: Used by the TSO to maintain the system frequency within operational limits, this program requires participants' demand to be automatically reduced by a minimum of $10 \mathrm{MW}$ during at least 10 minutes after an advance notification of 30 seconds. Participants are paid for availability $(€ / h)$, nomination $(€ / h)$ and response energy (€/MWh).

- Frequency Control by Demand Management: Enrolled customers' energy use is automatically interrupted by means of a frequency relay when the system frequency goes below a predefined reliability value. Participants must deliver a minimum of $3 \mathrm{MW}$, individually or aggregately, within two seconds after notification, maintaining the reduction for a minimum of 30 minutes. Customers receive an availability payment.

\subsubsection{Italy}

Italy is the European country where the implementation of advanced electricity meters has been the most successful, with about the $90 \%$ of all meters already installed [24].

Customers willing to participate in load reduction programs can enrol in the interruptible load service, which is based on the availability of customers to interrupt their energy supply when generation resources are not sufficient to maintain the operational security of the system [76]. According to the notification time, there are three different types of programs: in real time, with a required response within $200 \mathrm{msec}$ after a remote signal is sent by the TSO; in deferred time under emergency conditions, with an activation time under five seconds after the order emission; and with notice, when 
customers are allowed 15 minutes to reduce their loads after reception of the reduction order.

Regarding TOU tariffs, used by Italian customers for several years, a new product was launched in 2010 that offers more expensive prices from 8:00 am to 7:00 pm from Monday to Friday, and cheaper prices for the rest of time [24].

\subsubsection{Spain}

Since 1998, the Spanish electricity market has been largely and successfully deregulated. Only customers demanding less than $10 \mathrm{~kW}$ are allowed to buy electricity at a regulated tariff, while the rest must do it directly on the market. The ownership of the grid remains monopolistic under Red Eléctrica de España (REE), which is also the TSO for the Spanish electricity system. The distribution lines are owned by the distributors, which only transmit energy—not buy or sell it. Customers pay a fee, the Access Tariff, to the grid owners as for the use of their lines, but the supplied electricity is bought from the traders at a price that is freely negotiated between customer and seller.

- TOU Access Tariffs $\underline{29}$ : Customers with an electricity contract must sign an Access Tariff to pay the owner of the grid for its utilization. These tariffs, which represent about the $20 \%$ of the total electricity bill, charge different prices for energy and contracted power depending on the period of time under consideration (peak, shoulder and valley periods are distinguished). The most complex tariff includes six different periods with peak and shoulder in high season, peak and shoulder in medium season, shoulder in low season and valley for the whole year, including nights, weekends and holidays. The origin of this tariff resides in the old THP

\footnotetext{
${ }^{29}$ The Access Tariff was established by the Royal Decree 1164/2001
} 
(hourly power tariff), which was in force from 1994-2007. It also had a seventh period (the most expensive one), consisting of 13 hours a day during 23 high season days established by REE at its discretion [77]. Unfortunately, and despite being a very interesting product from the demand-side point of view, it was discontinued after failing to show any significant results when it was activated.

- Interruptibility Program ${ }^{30}$ : An interruptibility program was launched by REE in 1995 as a special tariff for large customers. A small and stable group composed by about 200 entities with reducible power capacity larger than $5 \mathrm{MW}$ could enjoy tantalizing rebates, in some cases up to the $80 \%$ of the total cost of the contracted power. However, it changed in 2007 when regulated tariffs yielded to contracts in the deregulated market, so that participation in this service was opened not only to large industries, but also to any other customer able to reduce a minimum of 5 MW when required by the TSO during emergencies. At the moment, there are 152 interruptible customers in Spain, which offer reductions of about $2200 \mathrm{MW}^{31}$. Depending on the notification time (from zero to two hours) and duration of the interruption (from one to twelve hours), there are five different types of contract. Interruptions can take place for up to 240 hours a year, with a maximum of one interruption per day and five per week. As a payment for their participation, customers receive a discount on their annual electricity bill of up to $20 € / M W h$. In this way, participants receive a payment even if no interruption is required. The load curve is

\footnotetext{
${ }^{30}$ It is regulated by the Ministerial Order ITC/2370/2007

${ }^{31}$ This information is available on the website of Red Eléctrica de España, S.A., accessed in September 2010: http://www.ree.es
} 
registered during the whole interruption event in order to verify the fulfilment of the order, and penalties are applied if customers do not actually reduce their power by the agreed amount.

\subsection{Conclusions of the Chapter}

The main demand response programs offered either by utilities or system operators existing in the U.S. and in EU countries are presented in this chapter. A wide range of benefits could be obtained by customers if they decide to use the flexibility they have. However, as stated in conclusions of the EU-DEEP project, final customers are not yet acquainted with demand response capabilities, in large part due to lack of information and training on the benefits that they can bring [78].

Different interruptible programs and TOU tariffs seem to be the most common DR programs around the world. TOU tariffs are quite similar in the analyzed countries, although it is worth highlighting programs of special interest such as the Tempo Tariff in France, in which pricing periods are adjusted daily according to the real needs of the System. Nevertheless, one of the most significant differences between the existing interruptible programs in the U.S. and Europe is that in the second case, only emergencies trigger such programs.

One aspect with great potential for future development is the figure of the aggregator, commonly used in the U.S. but completely absent in the European markets, with the exception of the UK. The presence of aggregators would enable medium size customers to offer DR services that currently are not available for them. In the case of Spain, where the interruptibility program has been demonstrated to be an essential ingredient in the resolution of critical operating situations, only large customers able to offer reductions of about $5 \mathrm{MW}$ are allowed to participate individually. The following chapters will demonstrate how the potential participation of aggregations of other 
industrial and commercial customers can be very effective in establishing different DR services to enhance the operation of the systems, provided that suitable DR programs are developed for them.

One of the main conclusions that can be obtained from this chapter is that customers have not been sufficiently considered in the design phase of existing DR programs, and this has resulted in sup-optimal utilization of demand resources, which remain underexploited. Therefore, the need for a new methodology to incorporate the demand side in the design stage of DR programs has been reinforced. Consequently, a novel methodology to develop, evaluate and assess new DR products is necessary and has been designed in this dissertation. Such a methodology, focused on enhancing the flexibility of customers to be used in operation markets, is presented and justified in the following chapters. 


\section{CHAPTER 3 :}

\section{METHODOLOGY TO DEFINE NEW DEMAND RESPONSE PROGRAMS BASED ON CUSTOMER FLEXIBILITY: CUSTOMER EVALUATION}

\subsection{Chapter Overview}

The general methodology required to achieve the objectives of this dissertation is developed and justified in the next two chapters. In accordance with the conclusions of Chapter 2, the mains prescriptive aspects that should be taken into account in the design of such a methodology are the following:

- The methodology should be based on the evaluation and detailed analysis of customer processes, analyzing the impact that proposed DR actions may have on each individual energy-consuming process throughout the course of production. Instead of simply assessing the impact that a given DR action could have on the total energy demand of the customer, we superpose the effect that different DR actions have on every process, contributing in this way to filling gaps in consumer knowledge with regard to load management.

- Customers, grid operators and any stakeholder viewpoints should be accounted for in the design process, facilitating the identification of the potential benefits of the proposed new DR programs for regulators, who can base their actions on real customer capabilities. 
- The figure of the aggregator must be further developed in order to build larger demand packages that allow the system to use DR resources from a wide array of customers, rather than just from large industries.

The first phase in the development of the proposed methodology, focused on customer analysis, is dealt with in this chapter.

\subsection{Introduction to the Methodology}

No electricity market is complete without the active participation of the final consumer [9], so the regulator must create the adequate means of guaranteeing effective competition in electricity markets, including DR programs which allow customers to participate in such markets.

The present methodology is based on processes which vary according to different customer segments. For that reason, the first step is to establish the objective segment to be analyzed. Once the regulator has determined this segment, customers define what type of actions they are willing to perform in exchange for what cost. Thereupon, the regulator must assess what profits can be extracted from the application of those actions, including an economic assessment which considers both the profitability for the system, as perceived by the system operator (flexibility buyer), and the payments for customers (flexibility sellers). If the flexibility offered by customers affords some benefits to the system, then the regulator will propose an adequate framework to properly use it in operation markets. 


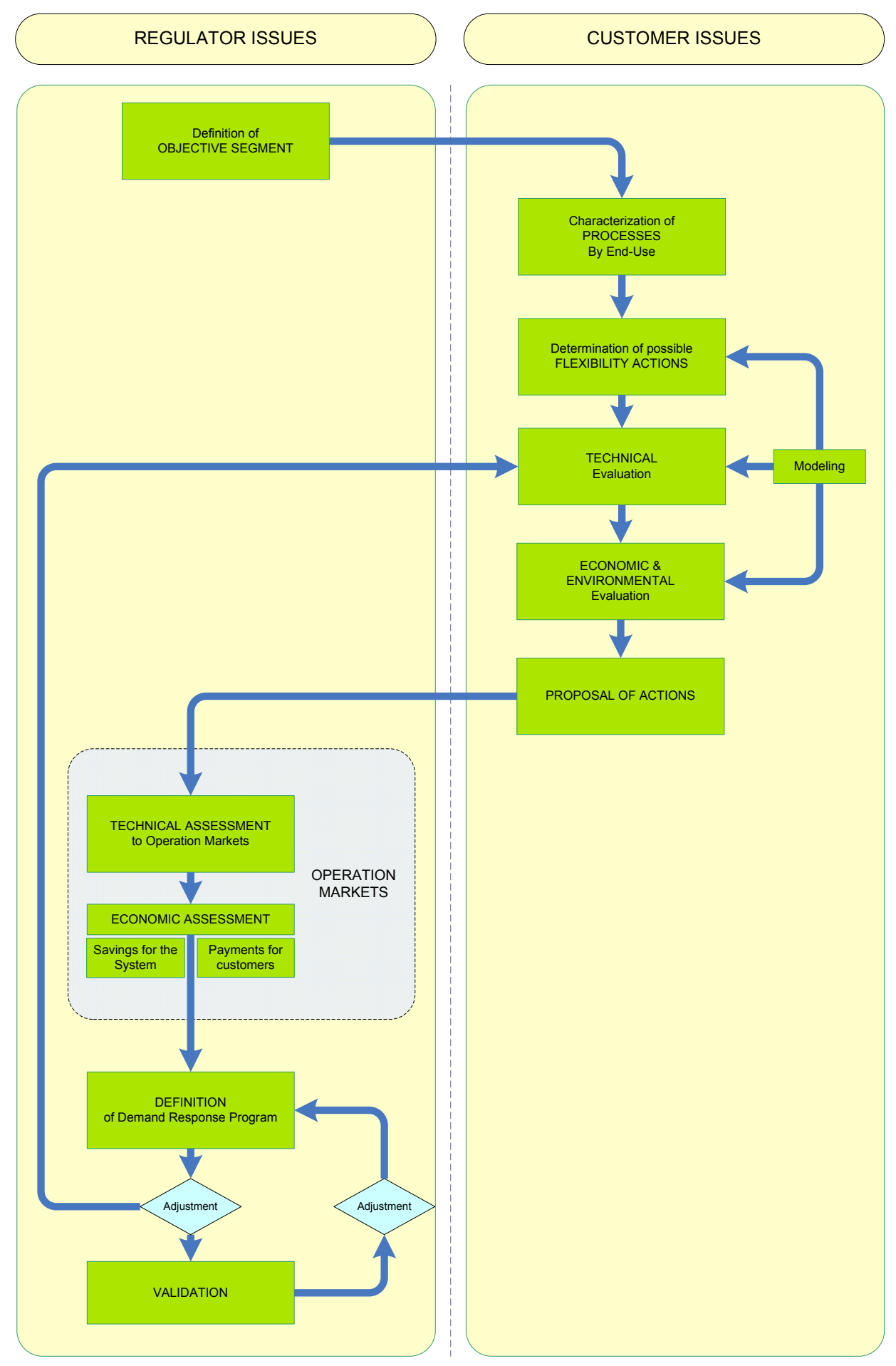

Figure 11. Methodology for developing DR programs based on customer profiling The proposed methodology is divided into two different blocks. The first block (regulator issues) details the different steps needed to develop DR programs from the system operation perspective, but taking into account customer abilities to modify their load profile. The customer issues block, in turn, describes the steps needed to carry out a proper characterization of process-based flexibility from the customer viewpoint. 
It is important to point out that the customer evaluates its flexibility prior to program implementation, so any flexibility action could theoretically be proposed by customers. This aspect provides the regulator with valuable information about the real potential of customers, who are not initially subjected to any rule or restriction that limits their possible actions. Consequently, DR programs are created once customers have already proposed what type of real actions they are able to perform, and the regulator will rule out the actions that have no objective value for the system. At present, programs are initially created taking into account only operational issues, and some potential customers are indirectly excluded.

As schematically presented in Figure 11, the methodology is divided into two blocks that clearly establish the different tasks to be performed by both the regulator (as program developer) and the customer. Each of these roles is detailed in the next sections.

\subsection{Definition of Objective Segment}

The first step of the methodology deals with the definition of the customer segment to be considered. As stated above, the present methodology uses a processbased approach, so DR programs based on customer flexibility must be developed for each specific segment, defined as groups made up of different customers who use the same or similar processes in terms of energy consumption.

Segment classifications commonly used by energy entities, such as the North American Industry Classification System (NAICS) in the U.S. or the National Classification of Economic Activities (NACE) in Europe, are based only on economic activities. For the purposes of our study, this strategy is problematic, since these classifications may group together customers with very different energy consumption 
activities, while other customers who consume energy in a similar way are considered separately.

In order to address this situation, the Institute for Energy Engineering of the Polytechnic University of Valencia (IIE-UPV) proposed a novel segmentation method during the EU-DEEP project [5], including a methodology to rank different segments according to their DR potential [6].

This "energy segmentation" classifies different activities not only by the amount of energy consumed by customers, but also how it is consumed. The segmentation envisions three different levels (see Figure 12):

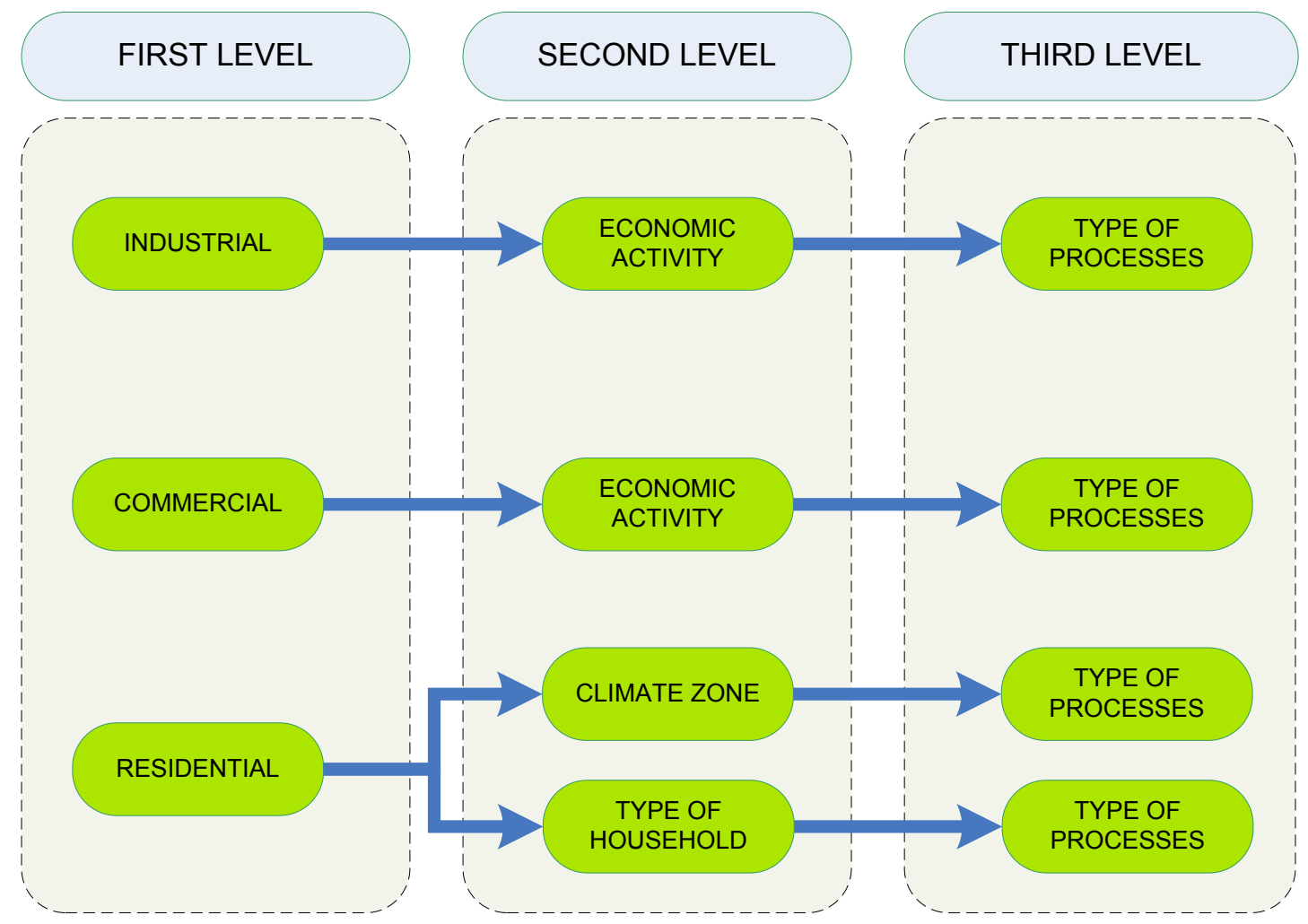

Figure 12. Segmentation methodology developed by IIE-UPV The methodology developed by the Institute for Energy Engineering in the framework of the EU-Deep project [5] envisions three levels of classification. The first level distinguishes between residential, commercial and industrial customers. The second level considers the economic activity of commercial and industrial customers as well as the climate zone and type of household for residential ones. Finally, the third level is based on the type of processes developed by each customer. 
1. The first level separates customers into three traditional sectors: commercial, industrial and residential customers.

2. The second level is based on the economic activity for commercial and industrial customers, while activities in the residential sector are classified by climate zone and type of household.

3. Finally, the third level disaggregates customers according to the processes or end-uses of energy.

Table 10. Ranking of the most suitable industrial segments for DR

\begin{tabular}{cll}
\hline Rank & $\begin{array}{c}\text { Segment } \\
\text { Code }\end{array}$ & \multicolumn{1}{c}{ Segment Description } \\
\hline 1 & I-15.51-02 & Milk and cheese industry \\
2 & I-27.10-01 & Iron and steel manufacturing (basic and tubes) \\
3 & I-15.96-01 & Beer manufacturing \\
4 & I-24.41-01 & Chemical products manufacturing \\
5 & I-34.10-02 & (Large) motor vehicles manufacturing \\
6 & I-15.51-01 & Ice-cream, milk and juice industry \\
7 & I-31.61-02 & Electrical equipment manufacturing for engines and \\
8 & I-36.10-05 & Furniture manufacturing (medium consumer) \\
9 & I-31.62-02 & Manufacturing of other electrical equipment (II) \\
10 & I-21.20-02 & Household and sanitary goods manufacturing \\
11 & I-15.40-01 & Manufacturing of oils, margarine and other fats \\
12 & I-90.01-01 & Wastewater collection and treatment \\
13 & I-22.21-03 & Newspaper printing \\
14 & I-15.11-01 & Meat and fish production and preservation \\
15 & I-36.10-02 & Furniture manufacturing \\
16 & I-24.50-01 & Manufacturing of toilet and cleaning preparations \\
17 & I-24.12-03 & Manufacturing of pigments and basic chemicals \\
18 & I-21.12-02 & Manufacturing of paper and paper board (large) \\
19 & I-31.62-04 & Manufacturing of other electrical equipment (IV) \\
20 & I-15.82-01 & Manufacturing of rusks, biscuits and preserved pastry \\
\hline & goods & \\
\hline & & \\
\hline
\end{tabular}

Source: EU-DEEP project [5] 
As a result of this segmentation, 378 industrial segments, 154 commercial segments and 90 residential segments were identified [79]. As an example, Table 10 shows the 20 most promising industrial segments identified for DR application.

The table shows that the highest DR potential corresponds to milk and cheese factories. The meat industry, which has been studied in detail for this dissertation, occupies the fourteenth position.

Significantly, six of the top 20 segments belong to the food industry, which indicates the high DR potential among this type of customer.

\subsection{Characterization of Processes by End-Use}

The description of an archetypical customer for the considered segment, as well as the decomposition of this customer's total load into main end uses, is crucial to flexibility analyses. From an energy perspective, the typical customer is a prototype whose characteristics represent the general behavior of any customer in the segment.

This task is highly specific and, consequently, very difficult for the industrial sector due to the wide variety of diverse processes that may be carried out in different factories devoted to different activities. On the contrary, only a few different processes are found in commercial or residential facilities. Subsequently, two residential or commercial customers that belong to different segments (for example, a hotel and a school) could have different ranges of consumption, but the physical processes for both are basically the same (air conditioning, ventilation, lighting, hot water...). On the other hand, processes for two different industrial customers such as a ceramics factory (molding, drying, enameling, firing) and a paper mill (pulp production, papermaking and cutting) may be completely different. Additionally, these processes could take place in dissimilar ways on different types of days (i.e working days vs. holidays). As a result, three types of input are obtained for each typical day at this stage of the methodology: 
- First, a list of different processes or end-uses corresponding to the customer archetype

- Secondly, a proportion of consumption associated with each of these processes

- Finally, a set of load curves for each process

Figure 13 shows the results for a prototypical ceramics factory which produces ceramic tiles on working days.
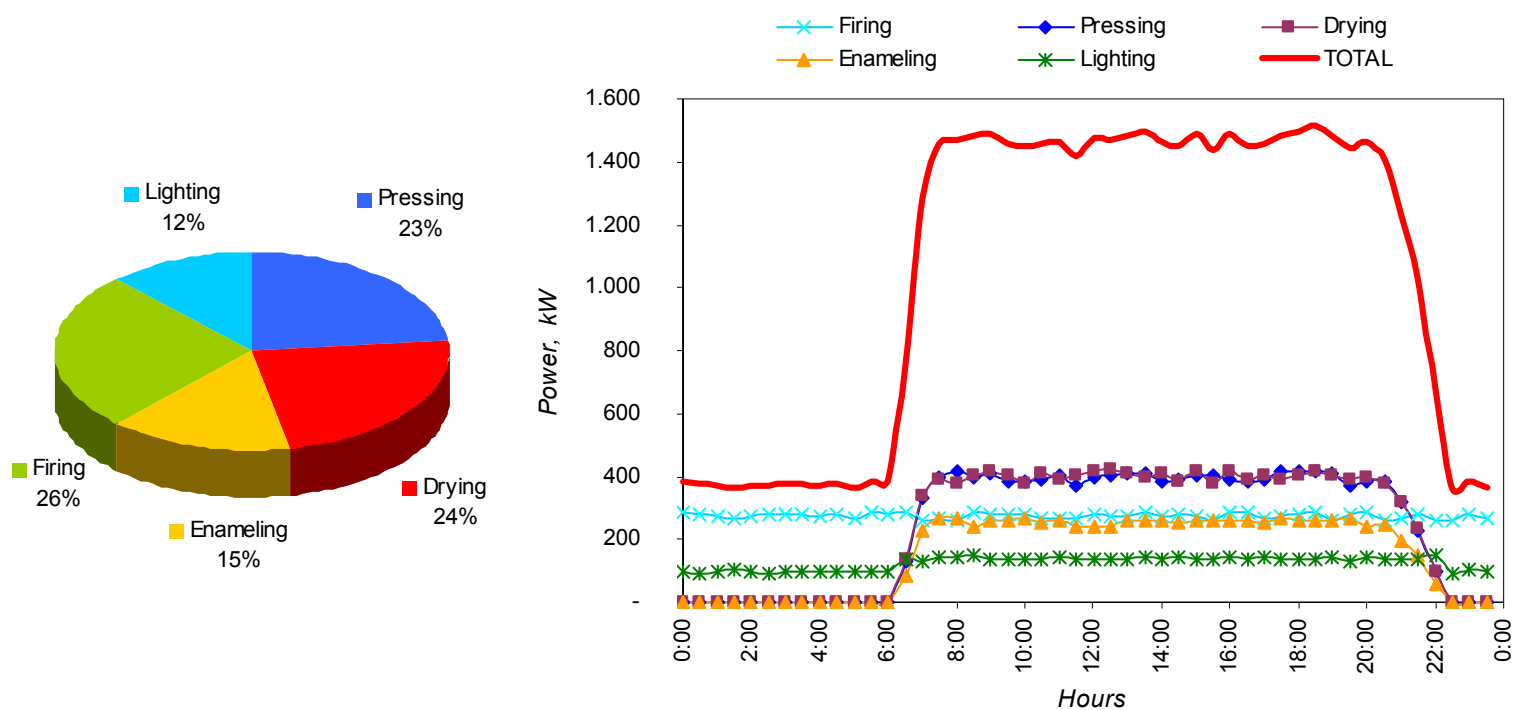

Figure 13. Production of ceramic tiles: demand characterization by end-uses On the left, a pie chart breaks down the proportion of electricity consumed by five principal processes in a prototypical ceramic tile factory on a regular working day. On the right, the total load curve of the factory is divided into processes, illustrating the consumption of each process at every hour.

As mentioned above, processes need to be considered independently when they are evaluated for different types of day. Figure 14 shows the total load curve, divided into processes, for the same example (a ceramic tile factory) on working days and holidays. 
a) Load curve on working days

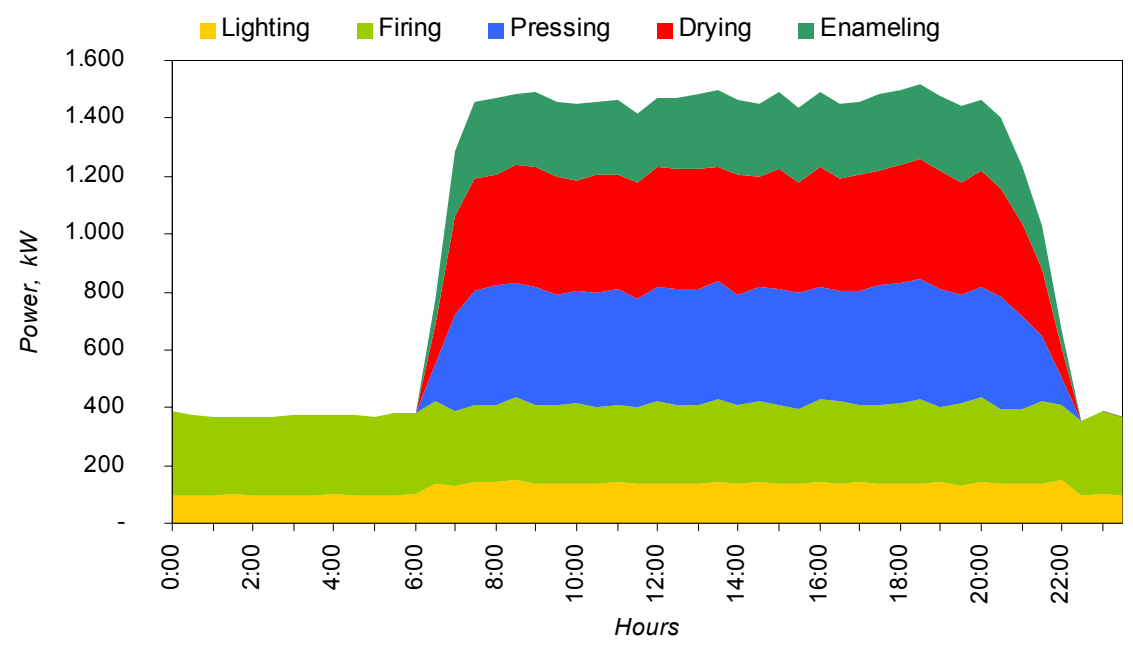

b) Load curve on holidays

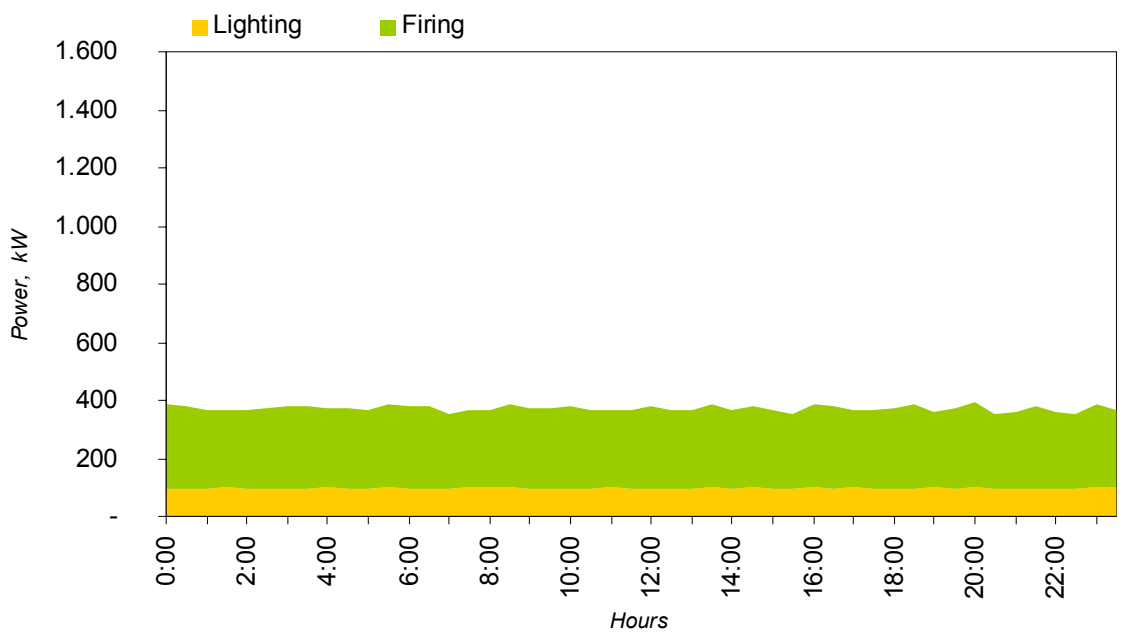

Figure 14. Production of ceramic tiles: load curves on different types of days

Part a) shows the total load curve for a prototypical ceramic tile factory during a working day, divided into end-uses or processes. Five different processes have been identified, and all of them take place from 6:00 am to 10:00 pm, with the exceptions of lighting and firing. These are the only two processes which function on weekends and holidays, as shown in part b), since firing is a continuous and relatively stable process. On the other hand, lighting is used less intensively from 6:00 am to 2:00 pm on holidays when compared to working days.

Obtaining these results requires detailed information about how processes are carried out, but only general data from sector studies are usually available. 
Consequently, in-depth surveys to obtain the necessary data from customers as well as proper process modeling are essential.

\subsubsection{Detailed Analysis of the Load Curve}

A detailed analysis of the load curve was obtained by means of the following steps:

- Identification of the typical days used by customers throughout the year. Such days usually follow one of these combinations:

a) A single type of day year-round: working day (factories operating continuously 365 days a year, whose processes are independent of the external temperature)

b) Two types of days: working day (from Monday to Friday) and nonworking day (weekends and public holidays).

c) Three types of days: working days (from Monday to Friday), Saturdays and holidays (including Sundays). This is customary for factories with two or three work shifts during the week and a half shift on Saturdays.

d) Five types of days: working days (from Tuesday to Thursday), Pre-holidays (Fridays and days preceding public holidays), Postholidays (Mondays and days following a public holiday), Semiholidays (Saturdays and days between two public holidays) and holidays (including Sundays).

Each one of these types can be sub-divided into two if seasonality is a factor, so that winter and summer days are considered separately. Figure 15 shows an example of a commercial customer belonging to the 
segment "Higher Education with sports facilities and residential buildings" where four different types of days were identified.

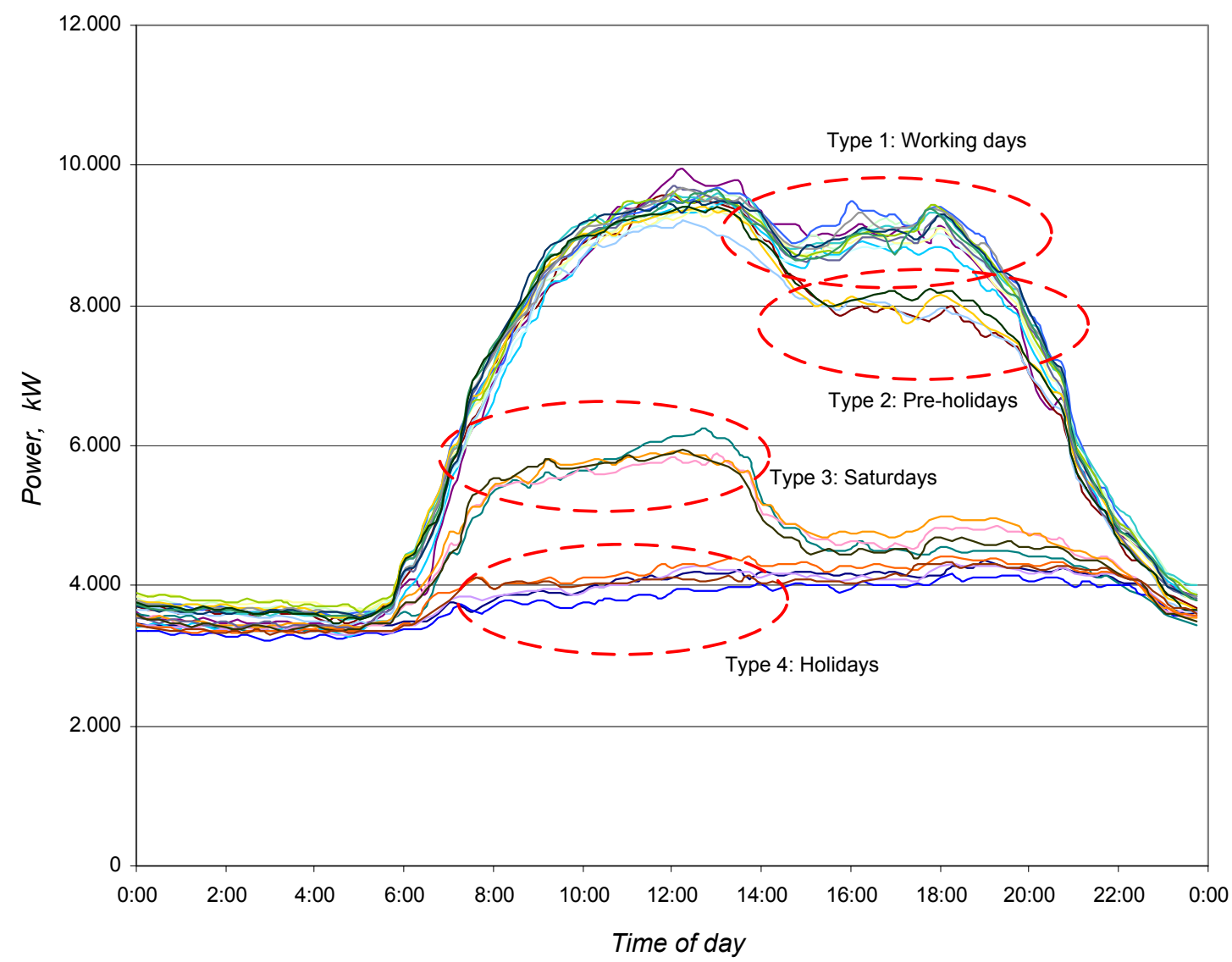

Figure 15. Identification of typical days in a commercial customer

This load curve represents the power required by the Polytechnic University of Valencia, a customer which belongs to the segment "Higher Education with sports facilities and residential buildings," registered during November 2009. For this period, four typical days were identified: working days (from Monday to Thursday), Pre-holidays (basically Fridays), Saturdays and Holidays (including Sundays).

- Identification of working hours in a day. Factories commonly follow an eight-hour shift system, so that the energy demand could be divided into one, two or three blocks of eight hours each. Consequently, processes will usually be performed during one or several working shifts. For 
example, in Figure 15, there are three clearly defined periods for working days: period 1 (valley) from 10:00 pm to 6:00 am, which is a non-working period; period 2 (peak) from 6:00 pm to 3:00 pm (morning classes); and period 3 (afternoon peak) from 3:00 pm to 10:00 pm (evening classes).

- Identification of peak periods during a day. This allows us to identify the two basic formats of load shapes:

- Flat load shape, if demand is constant during the whole typical day; this is a classic example of a continuous process.

- Non-flat load curve, if one or more peaks are observed during the day due to variability in some processes.

In the above example illustrated in Figure 15, day types 1, 2 and 3 have a non-flat load curve with a primary peak demand from 6:00 am to 3:00 pm and a secondary peak from 3:00 pm to $10: 00 \mathrm{pm}$, which correspond to class hours. Conversely, the load curve of a type 4 day is almost completely flat since the campus is closed.

- Identification of programmed demand reductions. These are usually related to shift changes and meal or coffee breaks. In Figure 15, there is a lunch break on working days from 2:00 pm to 3:00 pm.

\subsubsection{Physical Modeling}

Modeling is normally essential to break down the total load curve into different customer processes. It is usually a complementary aspect to a measurement process because sometimes it is impossible or excessively complicated to measure the load curve for all the identified processes.

Among the different types of models, physically based models are the only method to estimate the consumption of different processes (end uses) so that the results 
can be extended to all the customers in the same segment. Likewise, they are the only available tools to adequately investigate the effect of different demand side management options in a customer facility, especially when these have not been performed previously and no historical data about such actions are available. Results for specific processes may be common for different types of facilities, allowing the exploration of "process" rather than "customer" flexibility options.

Within physical modeling, building modeling (the energy modeling of buildings) stands out in terms of recent efforts to develop software to foster energy efficient buildings [5]. A number of models have been developed by universities, research centers and government agencies, as well as manufacturers, which have addressed and produced modeling tools for specific processes and sectors. Among a set of available modeling tools in the USA and Europe which were evaluated in this study, the most relevant are:

- DOE-2 and DOE-2.1E (the latter developed by Lawrence Berkeley National Laboratory) ${ }^{32}$. Used for building design and energy conservation analysis, these American programs have been used to develop state, national and international building energy efficiency standards.

- RIUSKA (Finland) ${ }^{33}$. This is used for the dynamic simulation of comfort and energy consumption in buildings (the core software is DOE 2.1E).

- VSAT (California Energy Commission) [80]. This model is able to assess ventilation strategies in a building from the perspective of efficiency in energy end-use.

\footnotetext{
32 http://www.doe2.com

33 http://www.granlund.fi
} 
- ENERGY-PLUS ${ }^{34}$. This demand simulation tool for buildings, whose development is based on BLAST ${ }^{35}$ and DOE-2, calculates thermal load balances, allowing the customer to adjust descriptive parameters of air conditioning systems. Its modular structure facilitates the implementation of new modules.

- $\mathrm{HOMER}^{36}$. This modeling tool, developed by the National Renewable Energy Laboratory of the United States, is based on energy balance calculus. Once electrical and thermal loads are specified, the model searches for a combination of generation resources, mainly renewable, in order to supply such loads at a minimum cost.

- MARKET MANAGER ${ }^{37}$. This tool, developed and supported by Abraxas Energy Consulting, is used for economic analyses in buildings. HVAC and lighting loads are modeled, and the effect of substituting the installed devices for more efficient ones is simulated. This tool includes machinery and device libraries to be combined in different ways.

- TRACE $700^{38}$. Developed by Trane Ltd. in the U.S., this is a design and analysis tool used for optimizing HVAC systems in buildings.

\footnotetext{
${ }^{34}$ http://apps1.eere.energy.gov/buildings/energyplus/

${ }^{35}$ BLAST (Basic Local Alignment Search Tool) is a heuristic algorithm, specially applied in fields such as bioinformatics, which can compare a query sequence with many others included in a database, finding the most similar sequence to the base. More information about this algorithm can be found at http://blast.ncbi.nlm.nih.gov/Blast.cgi

${ }^{36}$ https://analysis.nrel.gov/homer/

${ }^{37}$ http://www.abraxasenergy.com/marketmanager.php

${ }^{38}$ http://www.trane.com
} 
- TRNSYS ${ }^{39}$. The Universities of Wisconsin and Colorado started developing this tool in 1975 in order to simulate the dynamic behavior and transitory state of systems which use thermal energy.

Unfortunately, very little research and product development has been done on strategies to perform direct load control with an acceptable and controlled impact on the customer. To rectify this situation, the Institute for Energy Engineering of the Polytechnic University of Valencia developed and designed the numerical simulation toolbox FLEXMOD in the framework of the EU-DEEP project [5]. This instrument physically models the impact of Distributed Energy Resources (DER) (including distributed generation, distributed storage and demand response) on customers' thermal and electric loads.

\subsubsection{FLEXMOD: the UPV Modeling Tool}

FLEXMOD is structured through two modeling tools which make use of Matlab $®$ and Microsoft Excel $\circledast$.

The module FLEXMOD-DECRET, developed for commercial and residential sectors, is able to simulate load profiles for space heating and cooling, thermal storage and water heaters. A proper physical description allows electrical and thermal loads to be modeled. This tool was validated through different field tests performed in the UK, where it was applied on large office buildings, hotels, educational buildings (universities and research centers) and other commercial/residential segments. The European climate diversity is taken into account in the model, since simulations are strongly dependent on weather conditions.

\footnotetext{
${ }^{39}$ http://www.trnsys.com
} 


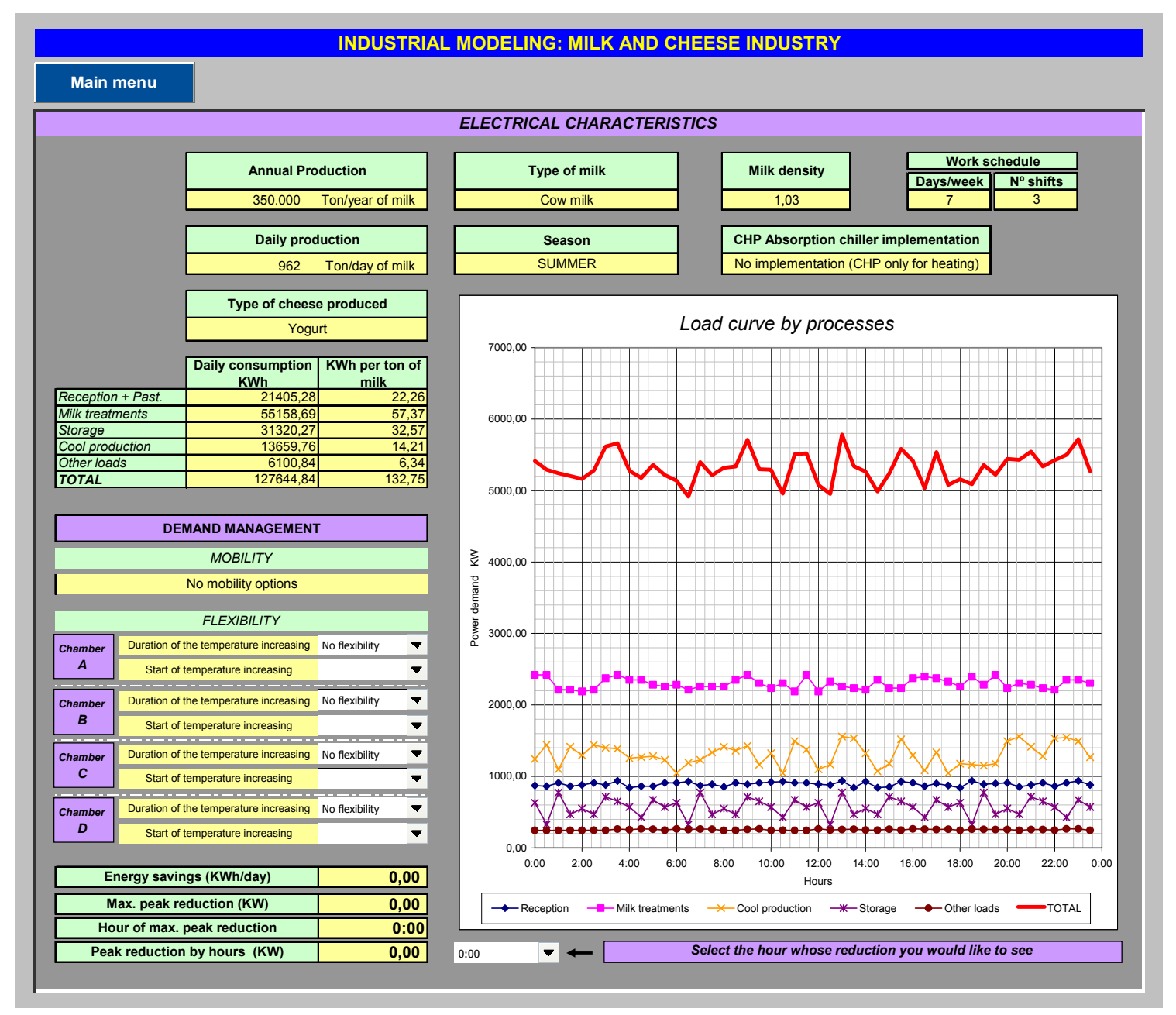

Figure 16. Screen shot of FLEXMOD DEIT.

The figure shows a screenshot of the electrical characteristics for the specific model of the milk and cheese industry. Once the customer has been properly characterized in the tool, and variables such as the type of milk and the annual production of the factory have been set, the customer's load curve, divided into end uses, is obtained, as well as the total and specific daily consumption corresponding to each process. As shown on the left of the screen, different flexibility actions can be evaluated, such as the interruption of cool production in storage chambers.

The module FLEXMOD-DEIT, developed by the author of this dissertation, consists of a set of user-friendly interactive Excel files specifically developed for each one of the studied industrial segments in the project. Five different tools for five different cases, identified by EU-DEEP as the most promising ones in terms of DER issues, were 
developed: furniture, wastewater treatment, ceramics, papermaking and cheese production. This set of tools also includes a detailed thermal and electrical analysis, and the impact of different flexibility actions identified in each segment can be easily assessed. Each specific tool was subsequently validated by using the methodology described in [81] and [82]. Figure 16 shows a screen shot from this tool.

\subsection{Determination of Possible Flexibility Actions}

The objective of this aspect of the methodology is to identify energy packages that can be reduced, interrupted or shifted by the customer when required by an external agent. Flexibility is highly dependent on the type of segment, process and customer activity, and it is customarily related to the following activities:

- Residential sector

○ Heating and air conditioning: decreasing (winter) or increasing (summer) the temperature setting for a period of time.

- Commercial sector

○ Heating and air conditioning: decreasing (winter) or increasing (summer) the temperature setting for a period of time

○ Electric water heating: reducing the duty-cycle during a fixed period of time

○ Ventilation: Reducing the airflow to approach minimums imposed by regulations during a period of time

- Industrial sector

- Cooling/freezing processes. Increasing temperature setting during a period of time

- Specific processes: Load interruption or reduction of flexible loads 
- Specific processes: Rescheduling to off-peak periods such as weekends or nights

The performance of one of the mentioned actions, as well as others that may be identified, will depend on how they affect the different processes, their possible impact on production and the investment required for their application. According to these principles, flexibility actions are classified below.

\subsubsection{Classification of Flexibility Actions}

Several actions can help customers to take advantage of their flexibility potential. The identified actions could be divided into the following types:

- Type 1: Actions that require no additional investment and have no impact on the customer activity. These actions are related to the interruption of inefficient devices whose operation does not render a profitable service. An example could be nighttime air conditioning in offices or HVAC devices functioning in temporarily idle workspaces. No investment is required for the implementation of these actions, since existing human resources can connect and disconnect the devices.

- Type 2: Actions that require investment and have no impact on factory production. These actions can be further divided into two groups: Subgroup 1 includes an improved or automated version of the actions considered in Type 1 above, where investment in an automatic control and management system will enhance effectiveness and reliability ${ }^{40}$. Sub-

${ }^{40}$ As a result of the project DERD performed by the Institute for Energy Engineering of the Polytechnic University of Valencia, a new Integral Management System (IMS), based on a secure website, was developed [7], [8], [84], [85]. This novel IMS is able to achieve decrements of $20 \%$ by means of active control and includes a set of new tools and techniques in order to improve the management of different energy resources used in existing infrastructures, resulting in a reduction in energy consumption, an increment in overall efficiency and the control of distributed loads. 
group 2 consists of a set of more sophisticated actions, such as ice storage [83], industrial use of free-cooling, etc. While the first set of actions aims to reduce unnecessary energy consumption and service use, actions included in sub-group 2 endeavor to reduce the total cost (economic and environmental) associated with the required energy use, either by directly reducing it or by displacing its production to cheaper energy cost periods (nighttime).

- Type 3: Actions with an admissible impact on production that may or may not require additional investment. The use of this type of actions is the most innovative aspect of the research presented in this dissertation because they have not been traditionally considered due to concerns about the possible impact on the final product. A typical example of application is the disconnection of loads related to cooling production and distribution in the factory. It is essential to guarantee that critical process parameters such as temperature or humidity will not reach unacceptable values that could compromise product quality.

\subsection{Customer Evaluation}

The evaluation of the impact that DR actions may have on the customer is directly related to the "package" of energy to be modified (usually through partial or total interruption): air conditioning, space heating, lighting, etc. in residential and commercial sectors and more specific production processes in industry. Therefore, a detailed analysis of each end use is required to assess this impact, as well as an evaluation of the link between the service provided (heat, air-conditioning, lighting, etc.) and the electricity use required for the process. Consequently, the cost associated with the implementation of the DR and the process degradation can also be evaluated [2], 
together with the reduction of $\mathrm{CO}_{2}$ emissions, which are directly related to energy consumption.

\subsubsection{Technical Evaluation}

Customers' technical potential to manage their energy consumption is evaluated by classifying the demand by different end-uses or processes, identified in section 3.4. For each of the processes "i," it is necessary to assess the following variables:

- $\quad$ Energy reduced during the action $\left(\mathrm{E}_{1, \mathrm{i}}\right)$

- Additional energy consumed before the flexibility action $\left(E_{2, i}\right)$ in order to adapt the process for the reduction or interruption

- Additional energy consumed after the action $\left(E_{3, i}\right)$, in order to re-establish the initial conditions

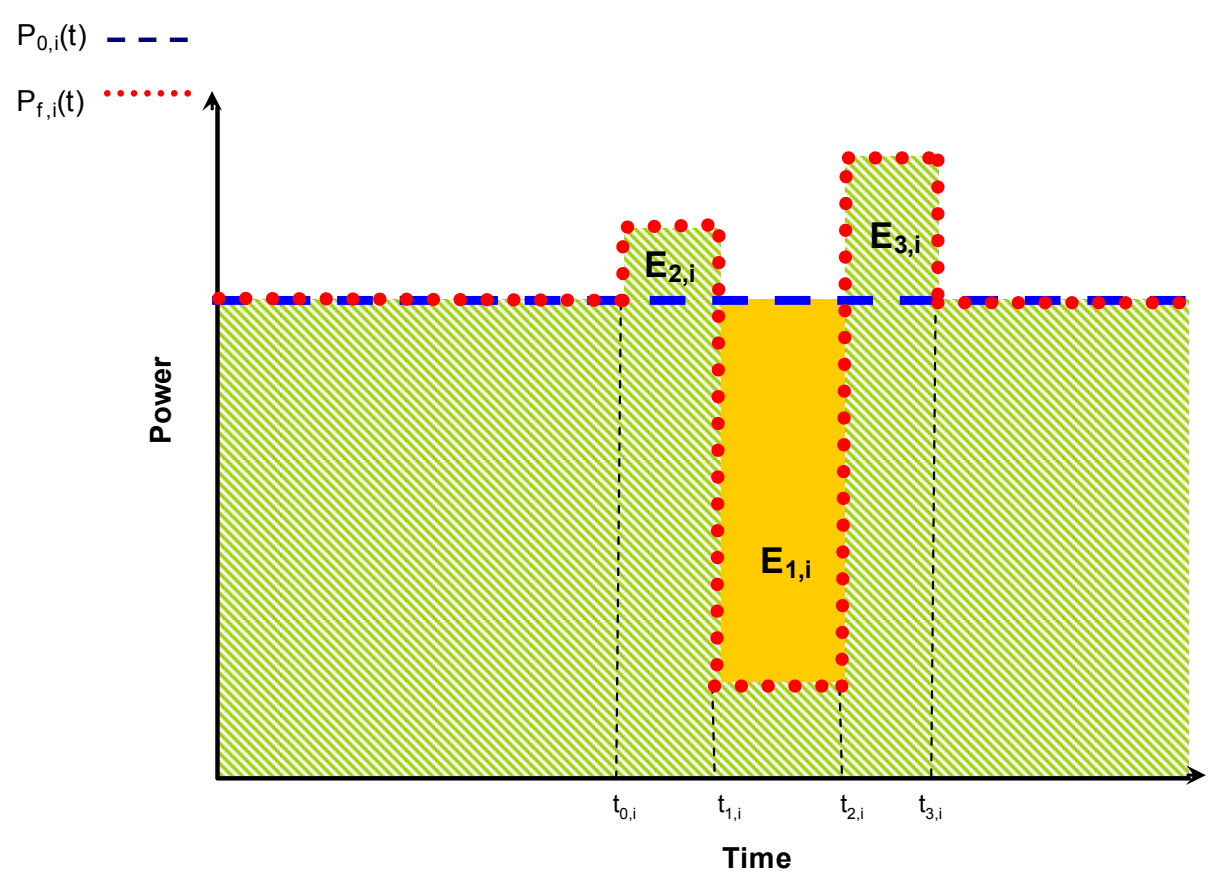

Figure 17. Theoretical model for technical evaluation of flexibility (flat shape) The figure illustrates a theoretical flat load curve for a process "i" (i.e. cooling in a typical food factory). From $t_{0, i}$ to $t_{1, i}$ an amount of energy $\left(E_{2,1}\right)$ is consumed in order to make adaptations to prepare for an interruption. Between $t_{1, i}$ and $t_{2, i}$, the interruption occurs, so the energy package $E_{1, i}$ is not consumed. At $t_{1,1}$, the interrupted supply is switched back on, and an extra consumption $E_{3, i}$ is produced to re-establish the original temperature setting. In $t_{3, i}$ the load curve returns to the initial level of demand. 
The net energy $E_{s, i}$ saved during the flexibility action applied to the process "i" can be calculated as follows:

$$
E_{s, i}=E_{1, i}-\left(E_{2, i}+E_{3, i}\right)=\int_{t=t_{0}}^{t=t_{3}}\left[P_{0, i}(t)-P_{f, i}(t)\right] d t
$$

$E_{s, i}$ is evaluated as the difference between the energy saved during the flexibility action $\left(E_{1, i}\right)$ and the additional energy consumed during the preparation $\left(E_{2, i}\right)$ and recovery $\left(E_{3, i}\right)$ periods. $P_{0, i}(t)$ is the load curve of the process "i" when any flexibility action is not performed; and $P_{f, i}(t)$ is the load curve of the process after applying the flexibility action. The flexibility action is delineated between $t_{1, i}$ and $t_{2,1}$, while the preparation period takes place from $t_{0, i}$ to $t_{1, i}$ and the recovery period is defined between $t_{2, i}$ and $t_{3,1}$ (see Figure 17 and Figure 18 for flat and non-flat load shapes).

Once the flexibility of the different processes has been obtained, the total energy saved or consumed in addition will be calculated by means of the formula,

$$
E_{s}=E_{1}-\left(E_{2}+E_{3}\right)=\sum_{i=1}^{N} E_{1, i}-\left[\sum_{i=1}^{N} E_{2, i}+\sum_{i=1}^{N} E_{3, i}\right]
$$

where $\mathrm{N}$ is the total number of processes considered. The amount of energy saved or consumed in addition must be assessed for each "k" period separately (onpeak, shoulder and valley), since the economic and environmental evaluation performed later in 3.6.2 will require these values. Consequently: 
Energy saved:

$E_{1}=\sum_{k=1}^{3} E_{1}^{k}=E_{1}^{\text {on-peak }}+E_{1}^{\text {shoulder }}+E_{1}^{\text {valley }}$

Extra energy consumed:

$\left(E_{2}+E_{3}\right)=\sum_{k=1}^{3}\left(E_{2}^{k}+E_{3}^{k}\right)=\left(E_{2}+E_{3}\right)^{\text {on-peak }}+\left(E_{2}+E_{3}\right)^{\text {shoulder }}+\left(E_{2}+E_{3}\right)^{\text {valley }}$

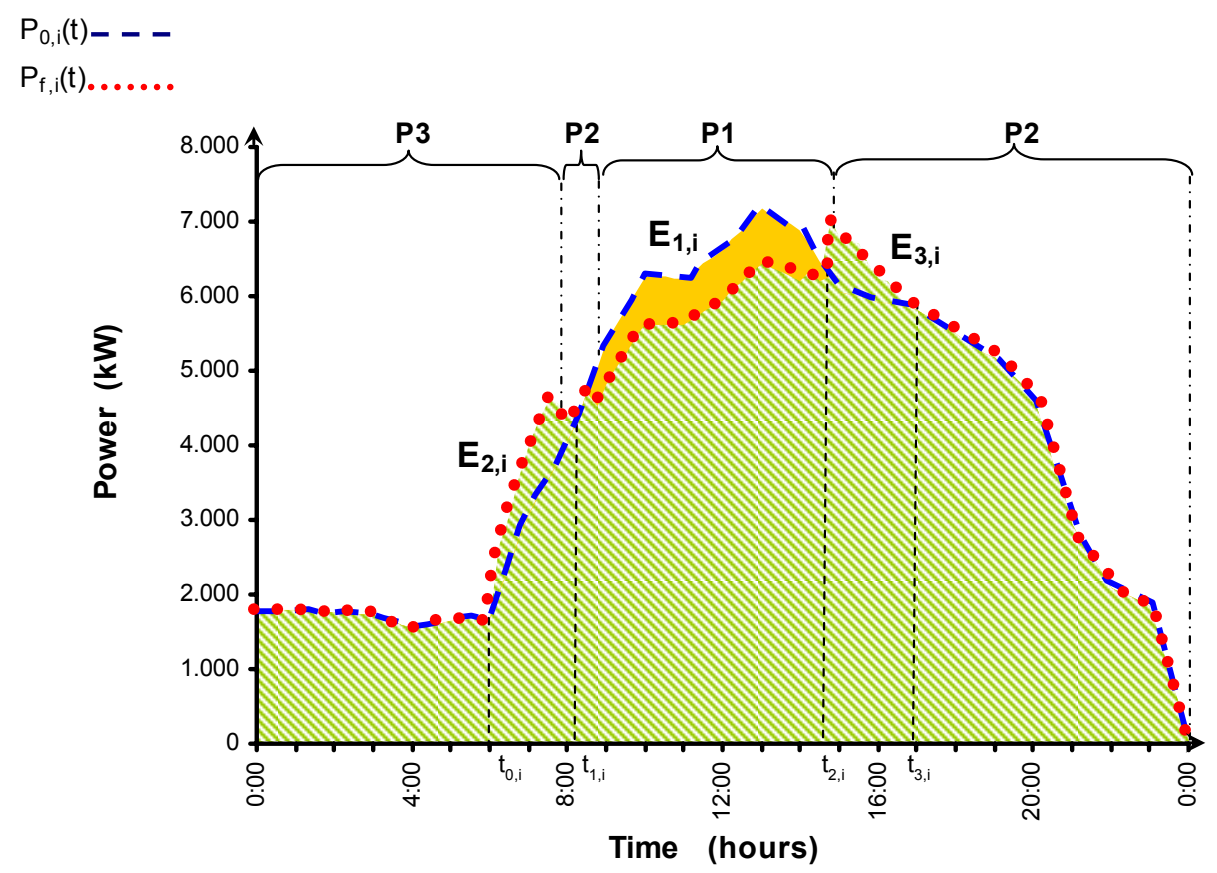

Figure 18. Example of a flexibility application on a non-flat shape customer The figure illustrates an example of a non-flat load curve for a process, "i," where consumption is higher in the morning and lower at night. This real example corresponds to the end use "Air Conditioning" at a University during the month of June. The load curve belongs to a customer who has a 3-period contract (P1 for peak, P2 for shoulder and $\mathrm{P} 3$ for valley). 


\subsubsection{Technical Evaluation of Flexibility in Flat Shape Processes}

There are different ways to assess the load shape that would be demanded without flexibility actions. When the power load curve of a process has a flat shape, as shown in Figure 17, the following straightforward method can be applied, as proposed and validated in [4]. This method is based on the evaluation of the average power demanded when no flexibility actions are applied, and the subsequent extrapolation to time periods when the load shape is modified due to reductions and recovery periods.

Usually, quarter-hourly load profiles are used to register demand power curves. Accordingly, the daily energy consumed by a process "i" during an interruption day $\left(\mathrm{E}_{\mathrm{c}, \mathrm{i}}\right)$ could be calculated by means of the following formula:

$$
E_{c, i}=\sum_{t=0}^{t=\frac{24}{T}} P_{i, t} \cdot T
$$

where $\mathrm{P}_{\mathrm{i}, \mathrm{t}}$ is the value of mean power required by process "i" in each quarter hour $(t)$, and $T$ is the interval of time considered. In this case, the value of $T$ is 0.25 hours, as intervals of 15 minutes are considered.

The energy saved during the interruption $E_{s, i}$ can be estimated by using the formula:

$$
E_{s, i}=24 \cdot \overline{E_{h, i}}-E_{c, i}
$$

where $\overline{E_{h, i}}$ is the average hourly consumption of energy without any DR action, computed according to this equation: 


$$
\overline{E_{h, i}}=\frac{\sum_{t=0}^{t=\frac{t_{0}}{T}} P_{i, t} \cdot T+\sum_{t=\frac{t_{3}}{T}}^{t=\frac{24}{T}} P_{i, t} \cdot T}{\frac{t_{0, i}}{T}+\left(\frac{\frac{24}{T}-t_{3, i}}{T}\right)}=\frac{\sum_{t=0}^{t=\frac{t_{0}}{T}} P_{i, t}+\sum_{t=\frac{t_{3}}{T}}^{t=\frac{24}{T}} P_{i, t}}{t_{0, i}+\left(\frac{24}{T}-t_{3, i}\right)}
$$

Here, the variable "t" takes integer values from 0 to $24 / T$. If $T$ is equal to 0.25 , and since quarter-hourly values are under consideration, "t" will range from 0 to 96 . Consequently, "t" will be equal to 0 for power demanded at 0:00, 1 for power demanded at $0: 15$, etc.

Due to its simplicity, this is the preferred method to evaluate the impact of customer flexibility, and it usually suffices for our purposes, as demonstrated by tests performed for the dissertation (see Chapter 6). However, if parameters such as external temperature or working patterns must be taken into account, more complex models such as those explained in [84] could be applied.

\subsubsection{Technical Evaluation in Non-Flat Shape Processes}

When non-flat processes are analyzed, such as the one shown in Figure 18, other methodologies are required in order to estimate the load curve that customers would have been consuming if no flexibility actions had been performed. In this case, the use of historical data, together with the physical models described in section 3.4 .2 could be useful (sometimes essential), especially when models have already been adjusted for the characterization phase. 
It is not the aim of this dissertation to design a new method to calculate the base line of the customer, as many valid examples already exist in technical bibliography [84] and could be used for this purpose.

\subsubsection{Economic and Environmental Evaluation}

The implementation of a flexibility action does not necessarily imply a reduction of the energy consumed. For example, if the milling process of a ceramics factory is shifted to another time period, the amount of energy not consumed during the usual schedule will be recovered when the process takes place. Although no energy savings are achieved, economic and environmental benefits would be obtained if the reduction occurs during a peak period and the recovery takes place in a shoulder or valley period, because prices and emissions are not the same for different periods throughout the day.

\subsubsection{Economic Evaluation}

The economic evaluation of flexibility requires a cost-benefit analysis in order to assess the net benefit that would provide the customer with enough incentive to reduce its load. The customer must evaluate the amount of money, $\mathrm{S}_{\mathrm{S}}$, saved during the flexibility action due to the energy not consumed or shifted to cheaper periods, as well as additional expenses, $\mathrm{C}_{\mathrm{f}}$, incurred when flexibility actions are performed. After that, it should establish the value of the benefit, $B_{\mathrm{NE}}$, it expects in exchange for offering the service to the system. These parameters are analyzed below.

\subsection{Savings $\left(\mathrm{S}_{\mathrm{s}}\right)$}

If $p_{1}, p_{2}$ and $p_{3}$ are the prices of energy for on-peak, shoulder and valley periods, respectively, the amount of money $\left(S_{s}\right)$ saved during the flexibility action can be calculated by using the formula: 


$$
S_{s}=S_{1}-\left(S_{2}+S_{3}\right)=\sum_{k=1}^{3} E_{1}^{k} \cdot p_{k}-\left[\sum_{k i=1}^{3} E_{2}^{k} \cdot p_{k}+\sum_{k=1}^{3} E_{3}^{k} \cdot p_{k}\right]
$$

where $S_{1}$ is the amount of money saved during the interruption, and $S_{2}$ and $S_{3}$ correspond to the extra costs generated by the consumption before and after the interruption (preparation and recovery periods). $E_{1}{ }^{k}$ is the amount of avoided energy for each "k" period of time during the interruption (explained in detail in section 3.6.1). Similarly, $E_{2}{ }^{k}$ and $E_{3}{ }^{k}$ are the amounts of additional energy consumed during the preparation and recovery time. It is important to point out that using flexibility may afford economic savings to customers even if no energy savings are achieved. These benefits can easily be calculated by using this equation.

\subsection{Cost of Flexibility $\left(C_{f}\right)$}

The use of flexibility may entail additional direct and/or indirect costs for customers that need to be evaluated. Direct costs relate to the technical capacity for carrying out a flexibility action, while indirect costs refer to those incurred as a consequence of the implementation of flexibility actions (requirement of additional manpower, loss of productivity, etc).

Direct costs comprise the following concepts:

- Cost of control $\left(\mathrm{C}_{\mathrm{C}}\right)$. This concept includes all actions related to the physical implementation of a flexibility-related control action. Similarly, investments to that end are denoted as the factor $C_{A M}$.

- Cost of monitoring and metering $\left(\mathrm{C}_{\mathrm{MM}}\right)$. Monitoring and metering equipment is usually employed for other applications besides flexibility. Consequently, this cost will be shared with other involved uses. 
- Cost of alternative dual supply $\left(\mathrm{C}_{\mathrm{AS}}\right)$. This cost includes fuel and technical maintenance costs when an alternative energy source is required in order to supply processes whose electricity consumption needs to be reduced. This is the case of diesel generators, accumulators or UPS batteries.

- Amortizations $\left(\mathrm{C}_{\mathrm{AM}}\right)$. This cost includes the annual amortization of investments required for the adaptation of facilities to implement flexibility actions. Investments comprise all the required equipment, including control, monitoring and metering devices.

Similarly, indirect costs are divided into the following groups:

- Labor cost $\left(\mathrm{C}_{\mathrm{LB}}\right)$. This is the additional payment that employees receive when they have to work overtime or during more expensive hours (for example nights and holidays).

- Losses $\left(\mathrm{C}_{\mathrm{LS}}\right)$. This cost assesses the loss of comfort or productivity. It is usually difficult to evaluate, so traditionally customers have not been allowed to perform any action that generated this cost.

The total cost $\left(C_{f}\right)$ will equal the sum of these concepts:

$C_{f}=C_{\text {DIRECT }}+C_{\text {INDIRECT }}=\left(C_{C}+C_{M M}+C_{A S}+C_{A M}\right)+\left(C_{L B}+C_{L S}\right)$

Neither the cost of energy consumed during the preparation nor during the recovery period are included in the above equation, since these costs have been already considered in term $\mathrm{S}_{\mathrm{s}}$

The evaluation of the costs characterized above is a difficult task. However, some research has explored the field. For example, an innovative modeling tool has 
been developed by IIE-UPV during the EU-DEEP project [5], which allows the identification, evaluation and assessment of the different costs related to flexibility.

\subsection{Payments from the System $\left(P_{\mathrm{M}}\right)$ and Expected Benefit $\left(B_{\mathrm{NE}}\right)$}

Customers pay the power system in exchange for their electricity supply. Conversely, the power system receives a service when customers participate in DR programs and must compensate them for its value.

The payment method for providing a DR service is established in the framework of an organized DR program, and the amount paid to the customer $\left(\mathrm{P}_{\mathrm{M}}\right)$ will be essential to determining whether the customer participates.

Customers must specify the value they require to modify their loads $\left(B_{N E}\right)$, which depends on their own market strategy. As a result of their compliance, they will reduce their loads when the net amount of money they receive $\left(B_{R}\right)$ is equal to or higher than the benefit they expect to receive, as illustrated by the equation:

$$
B_{N E} \leq B_{R}=S_{S}+P_{M}-C_{f}
$$

Consequently, the customer will only modify its load curve when the payment $\left(P_{M}\right)$ that the customer receives from the DR program operator for providing a service to the system satisfies the following condition:

$$
P_{M} \geq B_{N E}-\left(S_{S}-C_{f}\right)
$$




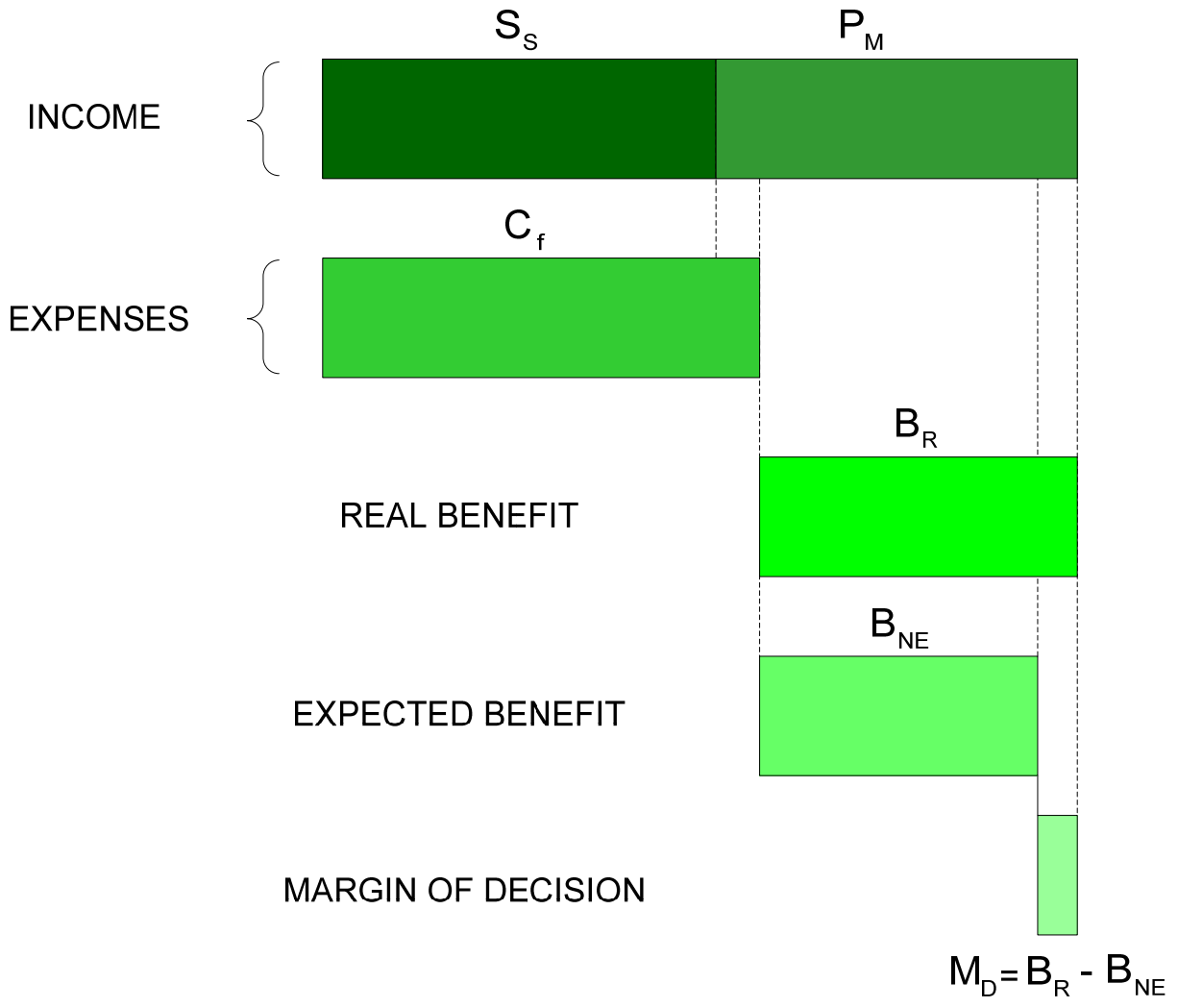

Figure 19. Economic evaluation of flexibility: cost-benefit analysis for customers The figure shows the relationship between costs and benefits with regards to customers' participation in DR services. The benefit obtained by the customer $\left(B_{R}\right)$ is equal to the difference between the income (benefits for consuming less expensive energy $\left(S_{S}\right)$ plus payments from the DR program operator $\left.\left(P_{M}\right)\right)$ and the costs that the customer incurs when a flexibility action is performed $\left(C_{f}\right)$. Customers will only participate in the DR program when expected benefits $\left(B_{N E}\right)$ are equal or higher than the obtained benefit $\left(B_{R}\right)$; in other words, when the margin of decision is positive.

As shown in Figure 19, the difference between the real benefit $\left(B_{R}\right)$ and the expected benefit $\left(B_{N E}\right)$ is the margin of decision $\left(M_{D}\right)$, which could be calculated as an index to verify the customer's potential participation in the DR program:

- If $M_{D}<0$, the customer will not participate in the DR program, as no benefits are obtained.

- If $M_{D} \geq 0$, the customer will provide the DR service, modifying the power load according to DR program requirements. 


\subsubsection{Environmental Evaluation}

Avoided atmospheric emissions can be assessed in a similar way by considering the coefficients which calculate the amount of $\mathrm{CO}_{2}$ per $\mathrm{MWh}$ emitted in each time period, factors that may differ depending on the power generation mix at the time under consideration.

An average value is generally used to evaluate avoided emissions at any time, and the computation consists of multiplying this factor by the amount of avoided energy. Nevertheless, this method is not always appropriate since it does not allow emissions to be assessed when energy consumption is shifted rather than reduced. Additionally, this average could vary by countries, depending on the proportion of "clean energy" in the total generation park. Table 11 shows the emission factors for different energy sources present in the generation mix of various countries and regions.

Identifying the technology used for regulation purposes every hour is a difficult task, so the emission factor can be estimated by using an average value obtained from the generation mix.

Consequently, the mean emission factor for each "k" period (on-peak, shoulder and valley) can be calculated by using the following formula:

$$
f e_{k}=\frac{E_{\text {coal }}^{k} \cdot e_{f-\text { coal }}+E_{\text {fuel-gas }}^{k} \cdot e_{f-\text { fuel-gas }}+E_{c_{-} \text {cycle }}^{k} \cdot e_{c_{-} \text {cycle }}+E_{\text {ren }}^{k} \cdot e_{\text {ren }}}{E_{\text {coal }}^{k}+E_{\text {fuel-gas }}^{k}+E_{c_{-} \text {cycle }}^{k}+E_{\text {renewable }}^{k}}
$$

where $E_{\text {coal }}^{k} E_{\text {fuel-gas }}^{k}, E_{{ }_{\text {__cycle }}}^{k}$ and $E_{\text {ren }}^{k}$ are the values of energy supplied by coal, fuel-gas, combined cycle and renewable technologies, respectively, during each "k" period, and $e_{f}$ values are the emission factors of each energy source as specified in Table 11. 
Table 11. Emission factors for different sources of energy and countries

\begin{tabular}{ccccccc}
\hline $\begin{array}{c}\text { Emissions } \\
\text { tonCO2/MWh }\end{array}$ & Spain & Sweden & Finland & UK & Japan & $\begin{array}{c}\text { EU } \\
\text { External }\end{array}$ \\
\hline Coal & 0.95 & 0.98 & 0.89 & 0.89 & 0.99 & 0.82 \\
\hline Fuel - gas & 0.70 & 1.17 & - & - & 0.65 & - \\
\hline $\begin{array}{c}\text { Gas combined } \\
\text { cycle }\end{array}$ & 0.37 & 0.45 & 0.47 & 0.36 & - & 0.36 \\
\hline $\begin{array}{c}\text { Solar } \\
\text { photovoltaic }\end{array}$ & 0.00 & 0.05 & 0.10 & - & 0.06 & 0.05 \\
\hline $\begin{array}{c}\text { Wind Power } \\
\text { Nuclear }\end{array}$ & 0.00 & 0.01 & 0.01 & - & 0.04 & 0.01 \\
\hline $\begin{array}{c}\text { Rest of } \\
\text { Hydraulic }\end{array}$ & 0.00 & 0.01 & - & 0.02 & 0.02 & 0.02 \\
\hline \begin{tabular}{c} 
renewable \\
\hline
\end{tabular} & 0.00 & 0.00 & - & - & 0.02 & - \\
\hline
\end{tabular}

Source: Red Eléctrica de España [86] for Spain and the World Nuclear Association (http://www.world-nuclear.org) for the rest of countries. According to the latter reference, emissions assigned to solar photovoltaic, wind power, nuclear and hydraulic are due to indirect causes from life cycle.

To illustrate, Table 12 shows the factors used in Spain for each period of time.

Table 12. Emission factors for different periods in Spain

\begin{tabular}{lr}
\hline \multicolumn{1}{c}{ Period } & $\begin{array}{c}\text { Emission factor } \mathbf{f e}_{\mathbf{k}} \\
\text { (tCO }\end{array}$ \\
\hline On peak and shoulder & 0.649 \\
Valley & 0.517 \\
\hline
\end{tabular}

Source: Spanish Departments of Industry and Housing [87]

The emission factor for the on-peak period is usually higher than for the rest of periods since the most inefficient technologies are supplying energy at these hours (coal and fuel-gas), and a higher amount of $\mathrm{CO}_{2}$ is emitted into the atmosphere. Therefore, if any amount of energy is shifted from the on-peak period to another period, a net 
reduction in emissions will be achieved. In the case of Spain, the emission factor for onpeak period is 0.750 tonCO $\mathrm{CO}_{2} / \mathrm{MWh}$.

Once the mean emission factors $\left(f_{i}\right)$ are calculated, avoided emissions $\left(A E_{s}\right)$ during a flexibility action can be calculated by means of the following equation:

$$
A E_{s}=A E_{1}-\left(A E_{2}+A E_{3}\right)=\sum_{k=1}^{3} E_{1}^{k} \cdot f e_{k}-\left[\sum_{k=1}^{3} E_{2}^{k} \cdot f e_{k}+\sum_{k=1}^{3} E_{3}^{k} \cdot f e_{k}\right]
$$

where $f_{i}$ are the emissions factors for each period "i": on-peak, shoulder and valley.

\subsection{Proposal of Actions}

After assessing and analyzing their flexibility potential in detail, customers must be able to specify the set of different actions necessary to exploit it, assuming that some actor in the market is willing to buy it. The different identified actions will be characterized by the following parameters, as shown in Figure 20:

- Amount of power reduced as a result of applying the flexibility action $\left(\Delta P_{R 1}\right)$. This could be a constant value or a schedule derived from different actions with varying values. The amount of power demanded during the interruption is known as residual power $\left(P_{R E S}\right)$.

- Increased power over the nominal value due to the additional consumption before $\left(\Delta P_{R 2}\right)$ and after $\left(\Delta P_{R 3}\right)$ the execution of the flexibility action (if this effect is produced).

- Operation times $\left(\mathrm{T}_{\mathrm{av}}\right)$. This parameter identifies the time periods in which the customer is able to apply the proposed flexibility action and, 
conversely, the periods without application. If the flexibility action can take place at any time during the day, $\mathrm{T}_{\mathrm{av}}$ will be equal to 24 hours.

- Duration of the action $\left(T_{D}\right)$. This is the time for which a reduction can be maintained. Usually, the higher the amount of power to be reduced, the shorter the duration of such an action. Similarly to $\Delta \mathrm{P}_{\mathrm{R} 1}$, it could be a unique value or a schedule composed of different times.

$P_{0, i}(t)---$
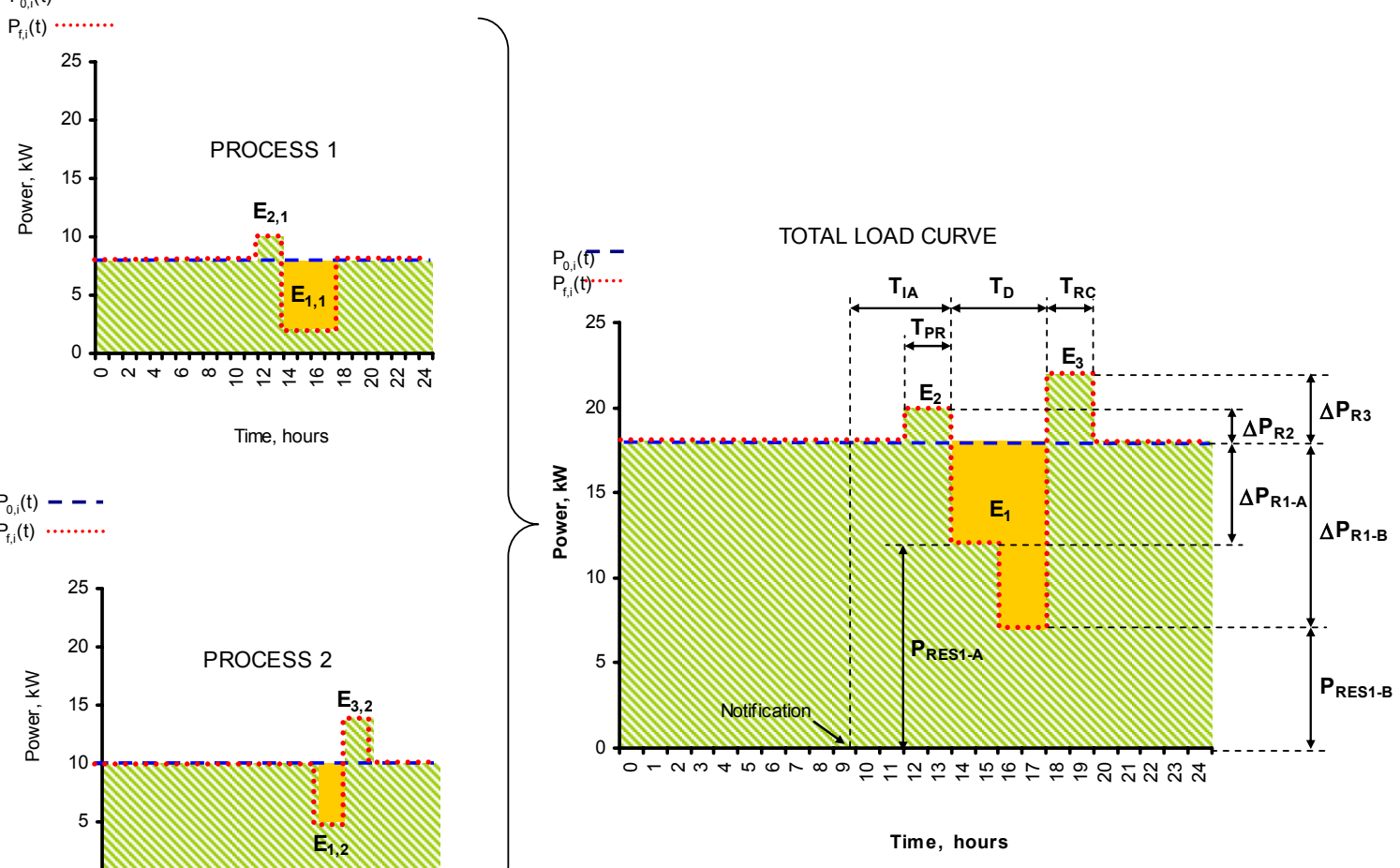

$P_{0,0}(t)--\cdot$

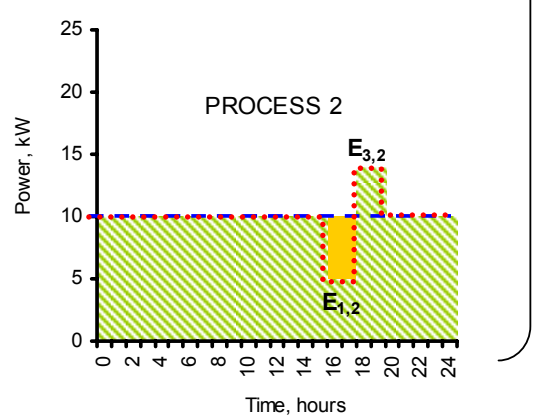

Time, hours

Figure 20. Example of a flexibility application by superposition

The left part of the figure represents the load curve of two different and flexible processes, where different reduction strategies can be applied. Process 1 can be reduced by $6 \mathrm{~kW}$ for three hours, while process 2 can be reduced by $5 \mathrm{MW}$ for two hours. A one-hour preparation period is required for process 1 , in which 2 additional MW are consumed; similarly, the demand involved in process 2 requires a recovery period of $4 \mathrm{MW}$ for one hour after the interruption. The total effect of these flexibility actions on the total load curve is shown on the right. 
- Duration of the preparation $\left(T_{P R}\right)$ and recovery periods $\left(T_{R C}\right)$.

- Advance notification time $\left(T_{I A}\right)$. This is the time required by the customer to prepare its processes in order to perform a flexibility action. Usually, the longer the reduction, the longer the notification time needs to be.

To illustrate this concept, Figure 20 shows an example of a customer with two processes on which different flexibility actions could be applied. Power in Process 1 can be reduced by $6 \mathrm{~kW}$ for three hours, following a preparation period of one hour, which generates an increase of $1 \mathrm{MW}$. Likewise, the power demanded in Process 2 can be reduced by $5 \mathrm{MW}$ for two hours, but this requires a recovery period of two hours in which demand rises by $2 \mathrm{MW}$. An advance notification time of four and a half hours is required. The customer schedule requires Process 2 to continue for at least two hours after the interruption of process 1 , so there is a difference of two hours between the start time of the reduction in Process 2 and Process 1. If the load curves are superposed, the response load curve shown on the right of Figure 20 is obtained as a result, corresponding to the whole facility. The values of the characteristic parameters detailed in this example are summarized in Table 13.

Table 13. Example of identification parameters card on customer flexibility

\begin{tabular}{cl}
\hline Parameter & \multicolumn{1}{c}{ Value / Description } \\
\hline$\Delta P_{R 1}$ & $6 \mathrm{~kW}$ for the first 2 hours / $11 \mathrm{~kW}$ for the next 2 hours \\
\hline$\Delta P_{R 2}$ & $2 \mathrm{~kW}$ \\
\hline$\Delta P_{R 3}$ & $4 \mathrm{~kW}$ \\
\hline$T_{A V}$ & 24 hours a day except in August \\
\hline$T_{D}$ & 4 hours $(2+2)$ \\
\hline$T_{P R}$ & 2 hours \\
\hline$T_{R C}$ & 2 hours \\
\hline$T_{I A}$ & 4.5 hours \\
\hline
\end{tabular}


Additionally, customers will have assessed the amount of money they expect to receive if they are required to perform any of these actions, as explained in section 3.6.2.1.

\subsection{Conclusions of the Chapter}

Customer issues related to the Demand Response design methodology proposed in this dissertation have been dealt with in this chapter. This customer analysis is based on the evaluation and assessment of flexibility in individual processes, as well as the final assembly to build the total load curve. This decoupled methodology allows the customer to study the behavior of each process separately, so that the impact of flexibility in the total load curve can be easily assessed by superposition.

A method has been designed to identify and characterize different customer processes according to how energy is consumed, by means of which both the amount of energy consumed and the shape of the load curve are obtained. Moreover, a tool has been developed to adequately evaluate and assess flexibility potential by considering the technical, economic and environmental benefit to be rendered.

One of the most significant contributions of this dissertation lies in the comprehensive consideration of both customer and grid operator perspectives. While this chapter studies customer performance in detail and clearly identifies flexibility potential, the next chapter deals with regulatory issues, defining demand response programs that pair the identified flexibility with the characteristics of operation markets. 


\section{CHAPTER 4 :}

\section{METHODOLOGY TO DEFINE NEW DEMAND RESPONSE PROGRAMS BASED ON CUSTOMER FLEXIBILITY: REGULATORY ASSESSMENT}

\subsection{Chapter Overview}

In the previous chapter, a new methodology to identify customer potential for participation in DR programs is developed. However, this potential has no value unless some agent in the electricity sector can benefit from it. Because it is clear that customer participation in every possible service to the power system is useful, the regulator has the burden of devising and implementing the necessary mechanisms to enlist customer collaboration, in line with the requirements of different operation markets where customers can participate. Consequently, this chapter focuses on the methodological aspects which assign a market value to customers' capability to react to electricity prices. With this information, the regulator can help to define the required programs to adequately exploit customer flexibility in operation markets, thereby enhancing the social benefit rendered by these programs.

\subsection{Integration of Flexibility in Operation Markets}

\subsubsection{Technical Assessment}

The methodology presented herein considers potential customer participation in operation markets by means of different DR programs, which are created by regulators and managed by system and distribution operators. A first step in this process will be to analyze the technical characteristics of operation markets in order to verify if products 
offered by customers, as described in section 3.7, can be paired with the requirements of such markets.

The analysis must necessarily deal with the following issues:

- Description of the main parameters that define operation markets in relation to the services provided by customers

- Identification of services that could be provided by customer utilization of their load flexibility

- Verification of customer capacity (in the segment under consideration) to actually provide the system with the required service.

Operation markets have different characteristics in diverse countries. However, the kinds of services provided are basically the same, as indicated in the following section.

\subsubsection{Operation Markets in Power Systems}

The aim of operation markets, whose services are managed by the transmission system operator, is to provide the System with the quality, reliability and security it requires. Operating power systems securely is the highest priority for system operators because the degradation of operation conditions in any part of the system can produce instabilities system-wide [88].

A general classification of the different services offered by operation markets is delineated in Figure 21, which contains the following elements:

- Solution of technical restrictions. This market is focused on solving incompatibilities in energy trading agreements between generators and consumers, which require the modification of the load-generation program paired to the electricity market. 
- Balancing markets. These are aimed at reconciling large deviations between loads and generation that could appear after the close of the electricity market. Such deviations could be caused by either generation outages or mistakes in the demand forecast [89].

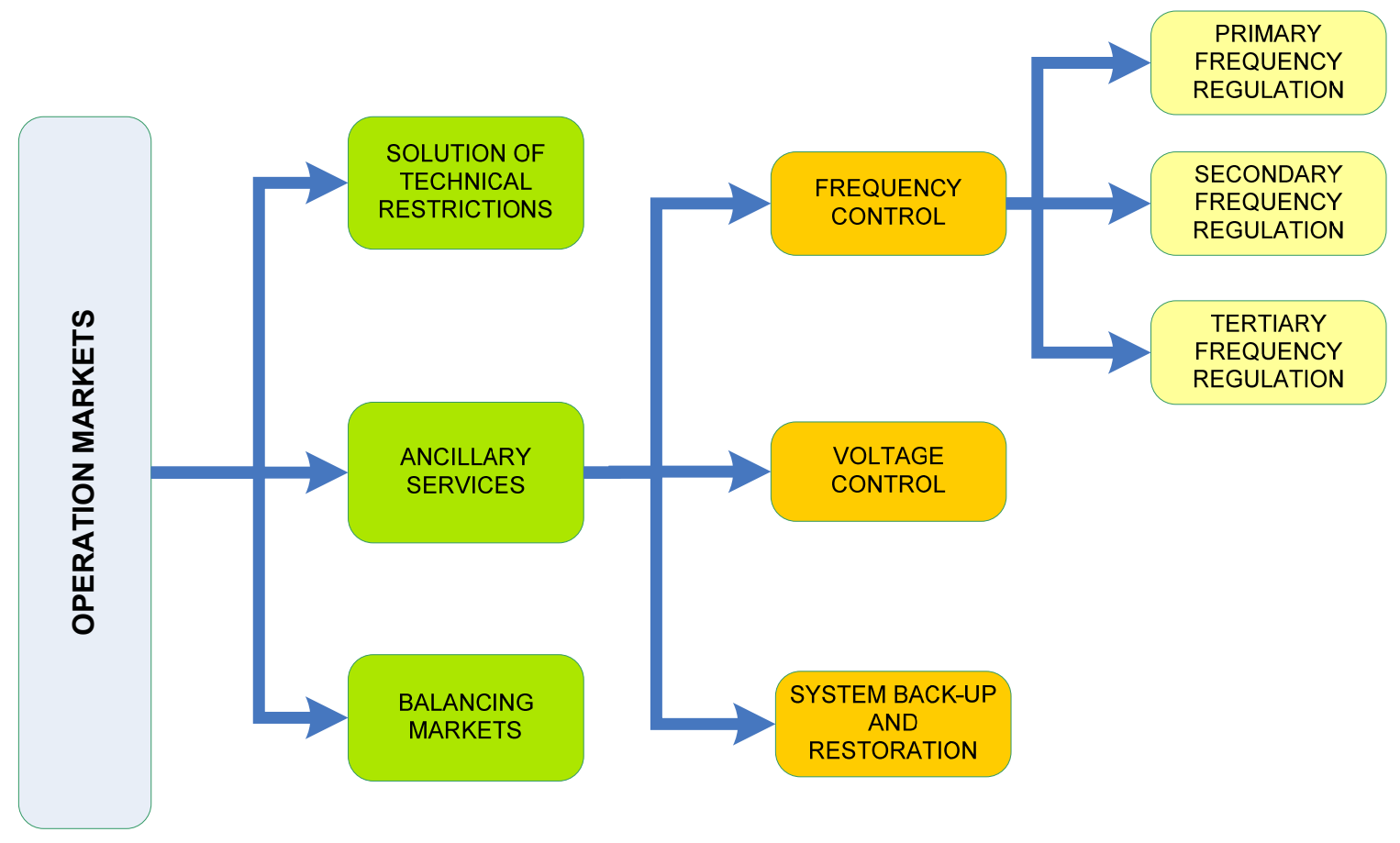

Figure 21. Classification of operation markets in power systems

According to the figure, operation markets can be divided into three different categories: those that resolve technical restrictions, those which provide ancillary services and balancing markets. Similarly, ancillary services include mechanisms of frequency control (primary, secondary and tertiary frequency regulation), voltage control, and system backup and restoration.

- Ancillary services. These services are necessary to guarantee a secure, reliable and high-quality energy supply. Traditionally, ancillary services have been divided into three groups [90]:

- Frequency control, related to the balance in real time of energy (load and generation) and frequency in the power system. 
- Voltage control, related to quality features in the supply apart from frequency, such as voltage regulation (also called reactive power service) [91].

- System backup and restoration, aimed at returning the system to normal operation status after experiencing a black-out.

The classification proposed in this section could be different between countries due to national regulatory issues, given that these services are not treated uniformly throughout the world. For example, the Federal Energy Regulatory Commission (FERC) in the U.S. distinguishes up to seven different ancillary services [92]. Conversely, other authors include ancillary services such as frequency control inside balancing markets [88], and tertiary frequency regulation is associated with balancing markets in Nordic countries [93].

\subsubsection{Customers Providing Operation Services}

Usually generators are the ones to provide operators with the different services required for the proper operation of power systems. However, regulations in some countries allow customers to participate in different operation markets if they can provide services by managing their loads while also fulfilling the requirements of power reliability and time of response.

Indeed, regulation is normally the only barrier for customers to provide these services to the power system. Consequently, regulators must design programs that allow wider participation of DR in operation markets, since customers are technically able to do so.

Customer potential to provide some of the mentioned services is discussed below. 


\subsection{Solution of Technical Restrictions}

Technical restrictions appear when overloads in power lines make it impossible to deliver the amount of energy demanded in the power market to customers. In order to solve this problem, the system operator may activate the following mechanism: reducing the power produced by certain generators and increasing the power produced by other generators as well as connecting new generators that were not previously used by the market.

Technical restrictions are managed differently in day-ahead and real time planning horizons. Usually, demand does not contribute to the solution of technical restrictions in the day-ahead horizon since this mechanism does not usually involve customers. Instead, the system operator is charged with guaranteeing that packages of energy bought by customers in the market are dispatched, even if more expensive generators must be used to provide the service. However, if reducing demand were cheaper than supplying energy by means of another generation resource, this service could be easily provided by DR.

Regarding the solution of technical restrictions in real-time, the participation of demand could be very significant (sometimes essential), representing the best and most profitable way to solve an event like this. A good example of this fact is the interruptibility program offered by the TSO in Spain (see section 2.6.2.9), which allows large customers to reduce their load in exchange for rebates in their annual electricity bill.

\subsection{Balancing Markets}

This service is used by system operators when significant differences between generation and demand arise after the closing of the power market. 
Balancing services have traditionally been provided by generation resources. However, customer participation is growing as they acquire permission to participate by means of load management [88].

Participation of DR in balancing markets is a common practice in some markets, such as the British Electricity Trading and Transmission Arrangements (BETTA) in the U.K., where customers can submit offers (proposed exchanges to decrease demand) or bids (proposed exchanges to increase demand) from the close of the market to the real time ${ }^{41}$. Another example is the power market in Texas, where customers use the BUL program to offer load reductions into the balancing energy market (see section 2.5.2.4). On the other hand, this is forbidden in Spain, where only generators are qualified to provide the service.

\subsection{Ancillary Services}

Ancillary services are understood as the set of services employed by grid operators to guarantee the safety and reliability of a power system [89].

Raineri and colleagues [90] evaluated the main characteristics of a number of ancillary services in different countries, including the Nordic countries (Denmark, Finland, Iceland, Norway and Sweden), California, Argentina, Australia and Spain. Their findings on these characteristics, as well as the possibilities for customer participation in certain countries, are discussed below.

\section{a) Primary Frequency Regulation}

This service, also called "Frequency Response" [94], is based on the automatic resolution of instantaneous imbalances between demand and generation in order to

${ }^{41}$ This information has been obtained from the website http://www.nationalgrid.com, accessed in November 2010. 
keep the frequency within its nominal value. The service is usually provided only by generators, which automatically modify the power produced as a response to frequency variation. However, as shown in Table 14, large customers can sometimes offer this service. For example, customers offering reductions higher than $50 \mathrm{MW}$ in the UK can provide the system with this service by means of the Fast Reserve Program (see section 2.6.2.7).

Table 14. Technical aspects of primary frequency regulation service

\begin{tabular}{cllll}
\hline \multirow{2}{*}{ Region } & Market & Response time & Duration & \multicolumn{1}{c}{ Provider } \\
\hline \multirow{2}{*}{ Europe } & U.K. & $10 \mathrm{~s}$ & $20 \mathrm{~s}$ & $\begin{array}{l}\text { Generators } \\
\text { and large customers }\end{array}$ \\
\cline { 2 - 5 } & Nordic & $30 \mathrm{~s}$ & Unlimited & Generators \\
\cline { 2 - 5 } North America & California & Instantaneous & Unlimited & Generators \\
\hline South America & Argentina & $\begin{array}{l}30 \mathrm{~s} \text { for thermal } \\
60 \mathrm{~s} \text { for hydraulic }\end{array}$ & 1 min & Generators \\
\hline Oceania & Australia & Between 6 and $60 \mathrm{~s}$ & $90 \mathrm{~s}$ & Generators \\
\hline
\end{tabular}

Source: "Technical and economic aspects of ancillary services markets..." [90]

b) Secondary Frequency Regulation

The aim of secondary frequency regulation (also called "Spinning Reserve" [94]) is to bring the system frequency back to its scheduled value [89]. The response period usually varies between 10 seconds and 15 minutes and is maintained for at least two hours [90]. Table 15 describes the service characteristics in different countries. In some places, like Spain, California or Argentina, only generators are authorized to provide the system with this service. On the other hand, customers can participate in the UK, the 
Nordic countries and Australia. For example, in the UK, customers can provide the system with this service through the Firm Frequency Response program (see section 2.6.2.7). In Nordic countries, secondary reserves are only used in West Denmark, where both generators and consumers can submit bids for upward or downward regulation. In Australia, customers can provide the system with secondary regulation through annual bilateral contracts [90].

Table 15. Technical aspects of secondary frequency regulation service

\begin{tabular}{|c|c|c|c|c|}
\hline Region & Market & Response time & Duration period & Provider \\
\hline \multirow{3}{*}{ Europe } & U.K. & $30 \mathrm{~s}$ & $30 \mathrm{~min}$ & $\begin{array}{l}\text { Generators and } \\
\text { customers }\end{array}$ \\
\hline & Nordic & $15 \min$ & 4 hours & $\begin{array}{l}\text { Hydraulic generators } \\
\text { and customers }\end{array}$ \\
\hline & Spain & $\begin{array}{l}\text { Between } 20 \mathrm{sec} \text { and } \\
15 \mathrm{~min}\end{array}$ & 1 hour & Authorized generators \\
\hline North America & California & $10 \min$ & 2 hours & Generators \\
\hline South America & Argentina & Minutes & Not specified & Authorized generators \\
\hline Oceania & Australia & $5 \mathrm{~min}$ & Not specified & $\begin{array}{l}\text { Generators and } \\
\text { customers }\end{array}$ \\
\hline
\end{tabular}

Source: "Technical and economic aspects of ancillary services markets..." [90]

\section{c) Tertiary Frequency Regulation}

The objective of tertiary frequency regulation (also called "Standing Reserve" [94]) is to replace the use of secondary reserve, so that the available reserve is returned to the initially scheduled value [89]. This service is usually only provided by generators, which must be available on 10 to 30 minutes notice and for a minimum of two hours. Although demand side participation is less significant for this ancillary service, countries 
like the UK have considered demand reductions as well as short notice generating units as providers of standing reserve for many years [95].

\section{d) Voltage Control}

This service is based on the use of generation and transmission resources to maintain the voltage of buses within an admissible range for the system. Voltage is dynamically maintained by managing the reactive power injected or absorbed from the grid. This service is typically provided by generators, synchronous condensers, capacitors and inductors, static VAR compensators and distributed generation equipment. However, customers are providing this service in some countries like Argentina (see Table 16), where voltage control is a joint responsibility of all the agents of the wholesale electricity market [90], and the power factor of generators, distributors and large consumers must be monitored.

Table 16. Technical aspects of voltage control service

\begin{tabular}{|c|c|c|c|c|}
\hline Region & Market & Response time & Duration & Provider \\
\hline \multirow{3}{*}{ Europe } & U.K. & Instantaneous & Not specified & $\begin{array}{l}\text { Generators with } \\
\text { capacities over } 30 \mathrm{MW}\end{array}$ \\
\hline & Nordic & $5 s$ & Not specified & All generators \\
\hline & Spain & Instantaneous & Not specified & $\begin{array}{l}\text { Generators, } \\
\text { transmission and } \\
\text { distribution companies, } \\
\text { some large customers }\end{array}$ \\
\hline North America & California & $1 \mathrm{~min}$ & Unlimited & $\begin{array}{l}\text { Generation, } \\
\text { transmission and } \\
\text { distribution companies }\end{array}$ \\
\hline South America & Argentina & Instantaneous & Permanent & All market participants \\
\hline Oceania & Australia & Instantaneous & Not specified & $\begin{array}{l}\text { Generators and } \\
\text { synchronous } \\
\text { condensers }\end{array}$ \\
\hline
\end{tabular}

Source: "Technical and economic aspects of ancillary services markets..." [90] 
In Spain, generators, transmission and distribution companies, as well as customers directly connected to transmission buses whose contracted power is higher than $15 \mathrm{MW}$, are qualified to provide this service. However, other customers with contracted power lower than $15 \mathrm{MW}$ could qualify by using an algorithm designed for special regime generators.

Table 17. Bonus coefficients for special regime generators in Spain

\begin{tabular}{ccccc}
\hline \multirow{2}{*}{$\begin{array}{c}\text { Power } \\
\text { Factor } \\
\text { type }\end{array}$} & Power Factor & \multicolumn{3}{c}{ Bonus \% } \\
\cline { 2 - 5 } & On peak & Shoulder & Valley \\
\hline \multirow{4}{*}{ Inductive } & $0.96>0.95$ & -4.0 & -4.0 & 8.0 \\
\cline { 2 - 5 } & $0.97>\mathrm{PF} \geq 0.95$ & -3.0 & 0.0 & 6.0 \\
\cline { 2 - 5 } & $0.98>\mathrm{PF} \geq 0.97$ & -2.0 & 0.0 & 4.0 \\
\hline & $1.00>\mathrm{PF} \geq 0.98$ & -1.0 & 0.0 & 2.0 \\
\hline \multirow{5}{*}{ Capacitive } & $\mathrm{PF}=1.00$ & 0.0 & 2.0 & 0.0 \\
\hline & $0.97>\mathrm{PF} \geq 0.96$ & 4.0 & 4.0 & 0.0 \\
\hline & $0.98>\mathrm{PF} \geq 0.97$ & 2.0 & 0.0 & -1.0 \\
\hline & $0.96>\mathrm{PF} \geq 0.95$ & 6.0 & 0.0 & -2.0 \\
\hline & $\mathrm{PF}<0.95$ & 8.0 & -4.0 & -3.0 \\
\hline
\end{tabular}

Note: Negative bonus entails penalties

Source: Royal Decree 661/2007. Available online: http://www.boe.es

This algorithm, as shown in Table 17, gives a bonus to customers injecting reactive power during on-peak periods and consuming reactive power during the valley. Conversely, penalties are applied to customers who consume reactive power during onpeak periods and who inject it during the valley.

While shifting the interruptibility program from the regulated to the deregulated electricity market, the Royal Decree $1634 / 2006$ envisaged the creation of a specific DR 
program for providing reactive power in Spain. However, to date, this initiative is still pending.

e) System Restoration

The aim of this service is to return the system to a normal operative state after a blackout, and it is typically offered by blackstart generating units (see Table 18).

As this service requires a net amount of power to be injected into the grid, demand side participation is not viable. However, the design of programs allowing customers with emergency generation resources to participate in the restoration of the system could be explored.

Table 18. Technical aspects of restoration by means of blackstart capability service

\begin{tabular}{cllll}
\hline Region & Market & \multicolumn{1}{c}{ Response time } & \multicolumn{1}{c}{ Duration } & \multicolumn{1}{c}{ Provider } \\
\hline Europe & U.K. & 2 hrs & $\begin{array}{l}\text { Between 1 and } 5 \\
\text { days }\end{array}$ & $\begin{array}{l}\text { Generators wit } \\
\text { capacities over 200 MW }\end{array}$ \\
\cline { 2 - 5 } & Spain & Not specified & Not specified & $\begin{array}{l}\text { Generators with } \\
\text { blackstart capability }\end{array}$ \\
\hline North America & California & 10 min & 12 hrs & $\begin{array}{l}\text { Generators with } \\
\text { blackstart capability }\end{array}$ \\
\hline South America & Argentina & $\begin{array}{l}\text { Dependent on the } \\
\text { provider }\end{array}$ & $\begin{array}{l}\text { Dependent on } \\
\text { the provider }\end{array}$ & All generators \\
\hline Oceania & Australia & $\begin{array}{l}\text { Dependent on the } \\
\text { type of service }\end{array}$ & $\begin{array}{l}\text { Dependent on } \\
\text { the type of } \\
\text { service }\end{array}$ & $\begin{array}{l}\text { Generators with } \\
\text { blackstart capability }\end{array}$ \\
\hline
\end{tabular}

Source: "Technical and economic aspects of ancillary services markets..." [90]

\subsubsection{Economic Assessment}

The economic assessment of DR participation in operation markets requires a cost-benefit analysis that considers the payments to customers in exchange for managing their loads (costs) compared to the amount of money that the whole power 
system would save if DRR were used instead of more expensive operation resources (benefits).

The benefit provided by DRR can be assessed by means of an avoided cost analysis. This concept is understood as the cost that the system does not incur when the amount of power required to resolve an imbalance is obtained through demand reduction rather than electricity production. Therefore, the system needs to evaluate the cost of different generation technologies in order to determine the profitability of reducing loads as opposed to generating additional power in order to solve imbalances in the grid.

\subsubsection{Avoided Costs Analysis}

When an amount of power is produced, generators have to assume different costs, including [96]:

- Capital costs. These comprise the value of the total cost of building and operating a generating plant through the course of its financial life. As costs are expressed in specific units for a year, it is common to use the concept of "average levelized cost" [97]. This is calculated by dividing the total capital cost into equal annual payments, which account for the amortization of generation facilities over their forecasted annual generated power (assuming a duty cycle that depends on the use of the considered technology). This is an important concept to be considered, given that the use of DRR can mean not only the reduction of generation in current available resources but also the delay in building new generation plants.

- Transmission and distribution costs. These costs include the amount of money that is spent when electricity is transmitted from generation plants to end users. When demand increases during on-peak periods, this cost 
also rises [96]. Consequently, the use of DRR during on-peak periods will be highly profitable for the system.

- Marginal energy costs. This includes the cost of fuel (when applicable), as well as the cost of transporting such fuel to generation facilities. Therefore, this cost is non-existent for most renewable technologies such as wind or solar power.

Table 19. Cost of generating electricity for different technologies in the U.K.

\begin{tabular}{|c|c|c|c|c|}
\hline Type & Source & Generation technology & cts $€ / k W h$ & $\begin{array}{l}\phi U S \$ \\
\text { /kWh }\end{array}$ \\
\hline \multirow{6}{*}{ Conventional } & \multirow{2}{*}{ Gas } & Gas-fired combined cycle turbine & 1.87 & 2.53 \\
\hline & & Gas-fired open cycle gas turbine & 2.64 & 3.56 \\
\hline & \multirow{3}{*}{ Coal } & Coal-fired pulverized-fuel steam plant & 2.13 & 2.87 \\
\hline & & Coal-fired fluidized bed steam plant & 2.21 & 2.99 \\
\hline & & $\begin{array}{l}\text { Coal-fired integrated gasification } \\
\text { combined cycle }\end{array}$ & 2.72 & 3.68 \\
\hline & Nuclear & Nuclear fission plant & 1.96 & 2.64 \\
\hline \multirow{4}{*}{ Renewable } & \multirow{2}{*}{ Wind power } & Onshore wind farm & 3.15 & 4.25 \\
\hline & & Offshore wind farm & 4.68 & 6.32 \\
\hline & Biomass & $\begin{array}{l}\text { Poultry litter-fired bubbling fluidized bed } \\
\text { steam plant }\end{array}$ & 5.78 & 7.82 \\
\hline & Wave/Marine & Wave and marine technologies & 5.61 & 7.59 \\
\hline
\end{tabular}

Source: The Royal Academy of Engineering, 2004 [97]. All figures have been converted from UK£ to $€$ and US\$.

- Operation and maintenance (O\&M) costs. This is a fixed expense whose total amount depends on the type of technology and the total number of hours it is utilized on an annual basis.

Costs that generators incur have been widely evaluated in technical bibliography for different countries [97], [98], [99], illustrated by the examples below. Table 19 details the cost of generating electricity delivered to the premises of the power station site in the 
UK. The total cost includes the capital cost of generating plants and equipment, the cost of the consumed fuel (when applicable) and O\&M costs.

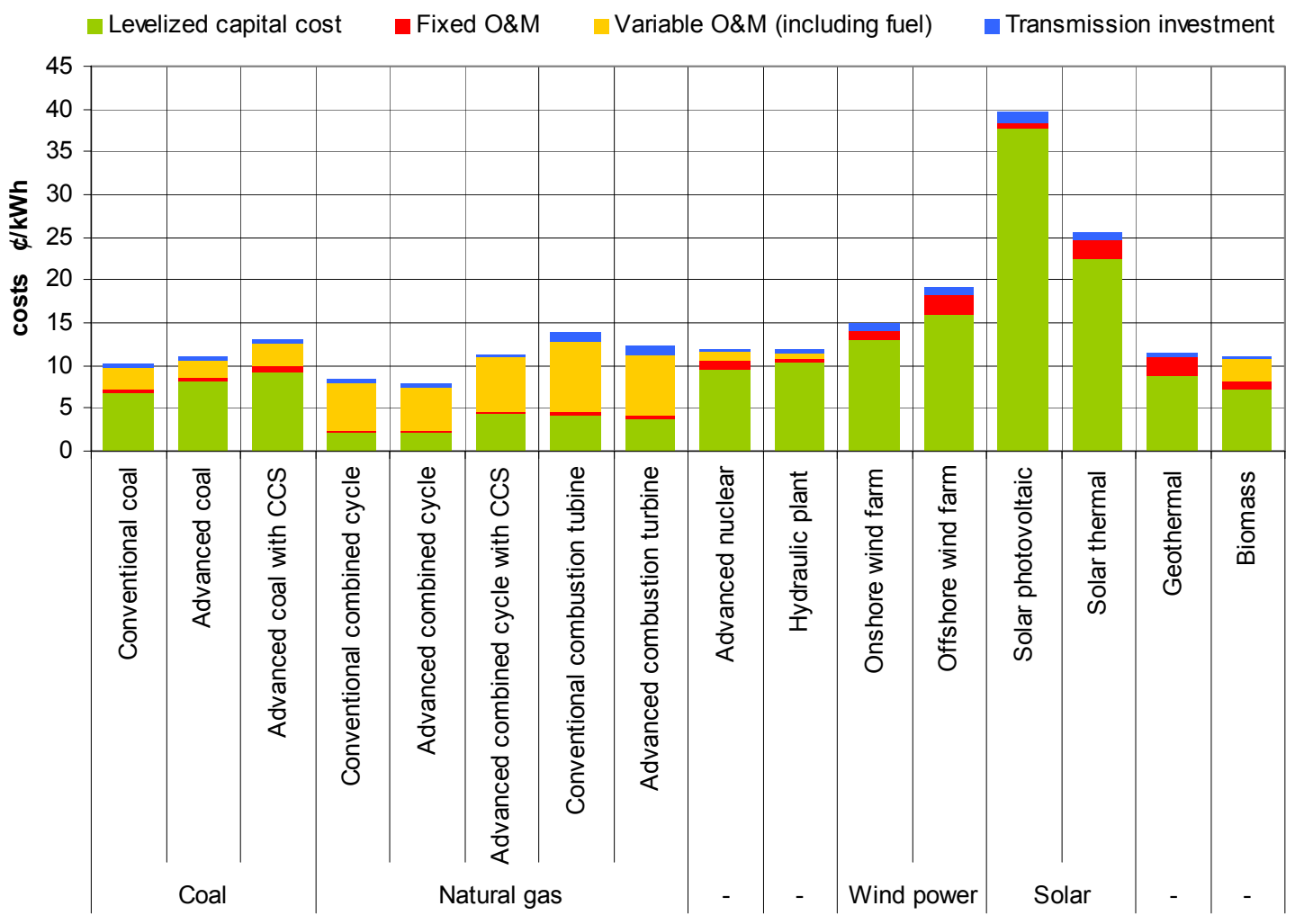

Figure 22. U.S. average levelized cost for plants commencing service in 2016 The figure represents the average costs for different types of generators in the U.S., in accordance with the data shown in Table 20. The most expensive technologies are renewable, where capital costs are very high. On the other hand, technologies related to the use of gas are the cheapest, although the cost of fuel is the highest for them.

Another example is presented in Table 20 and Figure 22, where the costs of generation in the U.S are exhibited. The total cost is divided into four items: levelized capital cost, fixed O\&M, variable O\&M and transmission costs.

Demand resources can competitively participate in operation markets when the cost of using such resources is comparable to the production prices of generation units. Therefore, demand resources will be accepted in those markets when they can provide 
the system with products more cheaply than generation resources, and after their ability to technically provide such services has been proven.

Table 20. U.S. average levelized costs (in $\phi$ of US $\$$ and $€$ ) for plants entering service in 2016

\begin{tabular}{|c|c|c|c|c|c|c|c|}
\hline \multirow{2}{*}{ Source } & \multirow{2}{*}{$\begin{array}{l}\text { Generation } \\
\text { technology }\end{array}$} & \multirow{2}{*}{$\begin{array}{c}\text { Levelized } \\
\text { capital } \\
\text { cost } \\
\phi / k W h \\
\end{array}$} & \multirow{2}{*}{$\begin{array}{l}\text { Fixed } \\
\text { O\&M } \\
\phi / k W h \\
\end{array}$} & \multirow{2}{*}{$\begin{array}{c}\text { Marginal } \\
\text { energy } \\
\text { cost } \\
\phi / k W h\end{array}$} & \multirow{2}{*}{$\begin{array}{c}\text { Transmission } \\
\text { and } \\
\text { distribution } \\
\phi / k W h \\
\end{array}$} & \multicolumn{2}{|c|}{ Total } \\
\hline & & & & & & $\phi / k W h$ & Cts $€ / k W h$ \\
\hline \multirow{3}{*}{ Coal } & $\begin{array}{l}\text { Conventional } \\
\text { coal }\end{array}$ & 6.92 & 0.38 & 2.39 & 0.36 & 10.05 & 7.43 \\
\hline & Advanced coal & 8.12 & 0.53 & 2.04 & 0.36 & 11.05 & 8.17 \\
\hline & $\begin{array}{l}\text { Advanced coal } \\
\text { with CCS }\end{array}$ & 9.26 & 0.63 & 2.64 & 0.39 & 12.92 & 9.55 \\
\hline \multirow{5}{*}{ Natural gas } & $\begin{array}{l}\text { Conventional } \\
\text { combined cycle }\end{array}$ & 2.29 & 0.17 & 5.49 & 0.36 & 8.31 & 6.14 \\
\hline & $\begin{array}{l}\text { Advanced } \\
\text { combined cycle }\end{array}$ & 2.24 & 0.16 & 5.17 & 0.36 & 7.93 & 5.86 \\
\hline & $\begin{array}{l}\text { Advanced } \\
\text { combined cycle } \\
\text { with CCS }\end{array}$ & 4.38 & 0.27 & 6.30 & 0.38 & 11.33 & 8.38 \\
\hline & $\begin{array}{l}\text { Conventional } \\
\text { combustion } \\
\text { turbine }\end{array}$ & 4.11 & 0.47 & 8.29 & 1.08 & 13.95 & 10.31 \\
\hline & $\begin{array}{l}\text { Advanced } \\
\text { combustion } \\
\text { turbine }\end{array}$ & 3.85 & 0.41 & 7.00 & 1.08 & 12.34 & 9.12 \\
\hline Nuclear & $\begin{array}{l}\text { Advanced } \\
\text { nuclear }\end{array}$ & 9.49 & 1.17 & 0.94 & 0.30 & 11.90 & 8.80 \\
\hline Hydropower & Hydraulic plant & 10.37 & 0.35 & 0.71 & 0.57 & 12.00 & 8.87 \\
\hline \multirow{2}{*}{ Wind power } & $\begin{array}{l}\text { Onshore wind } \\
\text { farm }\end{array}$ & 13.05 & 1.04 & 0.00 & 0.84 & 14.93 & 11.04 \\
\hline & $\begin{array}{l}\text { Offshore wind } \\
\text { farm }\end{array}$ & 15.99 & 2.38 & 0.00 & 0.74 & 19.11 & 14.13 \\
\hline \multirow{2}{*}{ Solar } & $\begin{array}{l}\text { Solar } \\
\text { photovoltaic }\end{array}$ & 37.68 & 0.64 & 0.00 & 1.30 & 39.62 & 29.29 \\
\hline & Solar thermal & 22.44 & 2.18 & 0.00 & 1.04 & 25.66 & 18.97 \\
\hline \multicolumn{2}{|c|}{ Geothermal } & 8,80 & 2.29 & 0.00 & 0.48 & 11.57 & 8.55 \\
\hline \multicolumn{2}{|c|}{ Biomass } & 7,33 & 0.91 & 2.49 & 0.38 & 11.11 & 8.21 \\
\hline
\end{tabular}

Source: U.S. Department of Energy, Energy Information Administration Annual Energy Outlook $2010 \quad$ CCS=Carbon Capture and Storage 


\subsection{Definition of Demand Response Programs}

As stated in section 2.4, there are two types of demand response programs:

- Operation programs, in which customers participate when grid operators consider that there is a situation that could affect the stability of the System

- Economic Based programs, used by customers to take advantage of different market prices, reducing energy consumption when market prices are higher

The scope of the present dissertation only deals with the first group of DR programs, as the potential benefits for both the power system as a whole and for individual customers are frequently higher. However, it is important to point out that the customer evaluation methodology designed in this dissertation is perfectly applicable to the design and assessment of any other economic based program that customers may use to participate in conventional (not operation) power markets.

\subsubsection{DR Programs for Operation Markets}

At this point, the regulator will have accurately analyzed customer flexibility and the different requirements of operation markets in the area under study. When technical characteristics of operation markets have been evaluated according to the specifications laid out in section 4.2.1, the regulator has all the information necessary to evaluate the average size of the power packages which are usually required in operation markets to solve imbalances between generation and demand. This information, together with regulator knowledge on the amount of power that individual or aggregated customers can provide to the system by managing their flexible loads (see section 3.6.1), allows the regulator to design demand response programs that will have the following characteristics: 
- These new programs will provide the system with the cheapest solution to solve the demand-generation imbalances. As demonstrated by means of an avoided costs analysis, demand resources providing this service can offer lower prices than other generation technologies.

- As demand is curbed, a net reduction of losses in the whole system is achieved, as well as a decrease in total emissions into the atmosphere.

- As the power being transmitted by the grid is reduced, the probability of technical restrictions due to overloads in transmission and distribution lines decreases, so that the system operates more efficiently and more securely.

- Customers will be able to offer both capacity and energy reductions according to their real flexibility potential. Therefore, these new programs will allow system operators to manage a higher amount of flexible and reducible power, as well as a wider range of flexibility actions, characterized by different energy packages with different power and prices.

The evaluation of flexibility actions has been developed for customers in a single segment. Similarly, the different DR programs developed should treat different operation markets separately since, as explained above, technical requirements for each one of them vary. Therefore, depending on the technical characteristics of each operation market, the design of DR programs based on real flexibility of customers will include the following elements:

- Specification of demand package characteristics to be reduced by customers according to the different operation market necessities. These characteristics are: 
○ Maximum, minimum and average amount of hourly power usually managed in the operation market under consideration

- Required response time, that is, the interval between the notification to the customer and the actual power reduction

- Duration of the action, understood as the maximum time for which a reduction can be maintained

- Analysis of identified reducible packages among customers, in order to verify the possibility of covering the requirements of operation markets with individual or aggregate DRR

- Design of the retribution algorithm to compensate customers. This algorithm should include the following terms:

- A fixed term to reward customers for the capacity they may provide to the system

- A variable term to pay customers for voluntary reductions

○ Finally, a variable term to pay customers for compulsory reductions

Some of the customer flexibility actions identified might need to be slightly modified in order to better pair them with the service they provide. Therefore, an adjustment stage is envisaged in the methodology which allows the regulator to revisit the customer's technical evaluation stage (see section 3.6.1).

\subsection{Validation}

Validation is the last step in the methodology; it is essential to monitor the proper performance of developed DR products. Once the program is designed taking into account the flexibility offered by customers and the utility that it could have for the system, the performance of designed programs will be evaluated according to the 
profitability that customers obtain when participating in such DR programs. Obviously, customers will only participate when reducing their loads provides them with economic advantages.

The technical success of designed programs is guaranteed since they have been created (section 4.3) according to the operation market requirements (section 4.2) and the actual flexibility that customers are able to offer (section 3.7). However, as payments to customers depend on operation market prices, the benefit obtained by customers could be lower than they expected. Numerically, this would occur when $B_{N E}>B_{R}$ (see section 3.6.2.1), as the value of $\mathrm{P}_{\mathrm{M}}$ may turn out to be more expensive than forecasted.

Although customers could initially perceive a DR program to be a non-profitable option since payments are too low, slight modifications in its characteristics could solve this handicap. Hence, an adjustment phase is envisioned in the methodology in case a revision of DR program design is required, as shown in Figure 11 (see section 3.2).

\subsection{Conclusions of the Chapter}

The second stage of the methodology, as developed in this chapter, is devoted to appraising customer flexibility for the operation and management of the power systems and to point out the interest in performing the required regulatory actions in the framework of the associated market mechanisms. A general classification of different operation markets has been proposed, and the most representative technical characteristics of some of these markets in different countries have been described.

One of the most significant conclusions from this section is that customers are already providing the system with different demand side options in different parts of the world, but potential use of DRR is actually far greater than its current presence in electricity markets. Indeed, customers are technically able to participate in operation markets and to reduce their loads quickly and reliably. Yet, participation needs to be 
enhanced by means of new DR programs and products which exploit the full and currently underused potential.

The economic assessment of designed DR programs is based on an avoided costs analysis, where marginal costs of different generation technologies in the U.S. and Europe, including capital, transmission and distribution, O\&M and fuel costs are considered. Once new DR products are designed according to the present methodology, a validation task is required in order to verify the profitability of such actions for customers, as they will only participate when reducing their loads provides them with economic advantages.

In the two previous chapters, the general methodology is explained. In subsequent chapters, we discuss the application of this methodology to a specific, energy-intensive customer segment, the food processing industry. The next chapter analyzes how energy is consumed in the food industry and evaluates the technical potential of detected flexibility, paying special attention to the meat industry, which has been studied in detail during the research for this dissertation. 


\section{CHAPTER 5 :}

\section{FLEXIBILITY AND EFFICIENCY ACTIONS IN THE FOOD INDUSTRY}

\subsection{Chapter Overview}

This chapter is devoted to the technical evaluation of flexibility in one energyintensive sector, the food industry. The methodology developed in previous chapters will be applied and validated for customers belonging to this sector.

First, a general overview of the sector is presented, including an activity classification according to international codes applicable in the U.S. and Europe. After that, a general description of how energy is consumed is presented, paying special attention to the different processes that are commonly found in this industrial segment.

Once the general analysis of the food industry has been carried out, the demand response potential in the sub-segment of the meat industry will be analyzed. This will be

done by applying the methodology developed in previous chapters to factories from this segment which have been studied in detail during the development of this dissertation.

Finally, a set of flexibility actions will be proposed and technically evaluated in order to assess the capability of this type of customer to participate in operation markets, according to the characteristics of the products they may be able to provide to the system.

\subsection{The Use of Energy in the Food Industry}

According to the objectives stated at the beginning of this dissertation, proper knowledge about how energy is consumed in the food industry is required in order to 
assess how DR can be used by customers in that sector. Therefore, the first part of this chapter is focused on the food industry, which consumes energy in order to process raw materials into higher value consumer food products [100].

The food industry can be divided into distinct activities or segments, which are grouped differently according to the specific national classifications in force. Table 21 shows such classifications according to NAICS and NACE, used in the U.S. and EU, respectively.

Table 21. Classification of the different food production activities according to the American and European National Codes NAICS and NACE

\begin{tabular}{|c|c|c|c|}
\hline \multicolumn{2}{|r|}{ American Code } & \multicolumn{2}{|r|}{ European Code } \\
\hline $\begin{array}{l}\text { NAICS } \\
\text { code }\end{array}$ & Description & $\begin{array}{l}\text { NACE } \\
\text { code }\end{array}$ & Description \\
\hline 3111 & Animal Food Manufacturing & 15.7 & $\begin{array}{l}\text { Manufacture of prepared animal } \\
\text { feeds }\end{array}$ \\
\hline \multirow{2}{*}{3112} & \multirow{2}{*}{ Grain and Oilseed Milling } & 15.6 & $\begin{array}{l}\text { Manufacture of grain mill products, } \\
\text { starches and starch products }\end{array}$ \\
\hline & & 15.4 & $\begin{array}{l}\text { Manufacture of vegetable and } \\
\text { animal oils and fats }\end{array}$ \\
\hline 3113 & $\begin{array}{l}\text { Sugar and Confectionery Product } \\
\text { Manufacturing }\end{array}$ & 15.8 & Manufacture of other food products \\
\hline 3114 & $\begin{array}{l}\text { Fruit and Vegetable Preserving and } \\
\text { Specialty Food Manufacturing }\end{array}$ & 15.3 & $\begin{array}{l}\text { Processing and preserving of fruit } \\
\text { and vegetables }\end{array}$ \\
\hline 3115 & Dairy Product Manufacturing & 15.5 & Manufacture of dairy products \\
\hline 3116 & Animal Slaughtering and Processing & 15.1 & $\begin{array}{l}\text { Production, processing and } \\
\text { preserving of meat and meat } \\
\text { products }\end{array}$ \\
\hline 3117 & $\begin{array}{l}\text { Seafood Product Preparation and } \\
\text { Packaging }\end{array}$ & 15.2 & $\begin{array}{l}\text { Processing and preserving of fish } \\
\text { and fish products }\end{array}$ \\
\hline 3118 & Bakeries and Tortilla Manufacturing & 15.8 & Manufacture of other food products \\
\hline 3119 & Other Food Manufacturing & 15.8 & Manufacture of other food products \\
\hline \multirow{2}{*}{312} & \multirow{2}{*}{$\begin{array}{l}\text { Beverage and tobacco } \\
\text { manufacturing }\end{array}$} & 15.9 & Manufacture of beverages \\
\hline & & 16.2 & Manufacture of tobacco products \\
\hline
\end{tabular}

Source: $\underline{\text { http://ec.europa.eu and http://www.census.gov/eos/www/naics/. }}$ 
Table 22. Classification of main processes in the food industry

\begin{tabular}{|c|c|c|c|}
\hline Group & & Unit operation & Examples of application \\
\hline \multirow{13}{*}{ Preparation } & \multirow{4}{*}{ Cleaning } & Washing & Fruits, vegetables \\
\hline & & Peeling & Fruits, vegetables \\
\hline & & Removal of foreign bodies & Grains \\
\hline & & Cleaning in place (CIP) & All food plants \\
\hline & \multirow{6}{*}{$\begin{array}{l}\text { Physical } \\
\text { separation }\end{array}$} & Filtration & Sugar refining \\
\hline & & Screening & Grains \\
\hline & & Sorting & Coffee beans \\
\hline & & Membrane separation & Ultra-filtration of whey \\
\hline & & Centrifugation & Separation of milk \\
\hline & & Pressing, expression & Oilseeds, fruits \\
\hline & \multirow{3}{*}{$\begin{array}{l}\text { Molecular } \\
\text { separation }\end{array}$} & Absorption & Bleaching of edible oils \\
\hline & & Distillation & Alcohol production \\
\hline & & Extraction & Vegetable oils \\
\hline \multirow{13}{*}{ Transformation } & \multirow{7}{*}{$\begin{array}{l}\text { Mechanical } \\
\text { transformation }\end{array}$} & Size reduction & Chocolate refining \\
\hline & & Mixing & Beverages, dough \\
\hline & & Emulsification & Mayonnaise \\
\hline & & Homogenizing & Milk, cream \\
\hline & & Forming & Cookies, pasta \\
\hline & & Agglomeration & Milk powder \\
\hline & & Coating, encapsulation & Confectionery \\
\hline & \multirow{6}{*}{$\begin{array}{l}\text { Chemical } \\
\text { transformation }\end{array}$} & Cooking & Meat, biscuits, bread \\
\hline & & Baking & Potato fries \\
\hline & & Frying & Wine, beer, yogurt \\
\hline & & Fermentation & Cheese, wine \\
\hline & & Ageing, curing & Deli products \\
\hline & & Extrusion cooking & Breakfast cereals \\
\hline \multirow{8}{*}{\multicolumn{2}{|c|}{ Preservation and storage }} & $\begin{array}{l}\text { Thermal processing } \\
\text { (blanching, pasteurization, } \\
\text { sterilization) }\end{array}$ & Canned vegetables \\
\hline & & Chilling & Fresh meat, fish \\
\hline & & Freezing & $\begin{array}{l}\text { Frozen dinners, ice cream, frozen } \\
\text { vegetables }\end{array}$ \\
\hline & & Concentration & $\begin{array}{l}\text { Tomato paste, citrus juice } \\
\text { concentrate, sugar }\end{array}$ \\
\hline & & Addition of solutes & Salting of fish, jams, preserves \\
\hline & & Chemical preservation & Pickles, salted fish, smoked fish \\
\hline & & Dehydration & $\begin{array}{l}\text { Dried fruit, dehydrated vegetables, } \\
\text { milk powder, instant coffee, } \\
\text { mashed potato flakes }\end{array}$ \\
\hline & & Freeze drying & Instant coffee \\
\hline \multirow{3}{*}{\multicolumn{2}{|c|}{ Packaging }} & Filling & Bottled beverages \\
\hline & & Sealing & Canned foods \\
\hline & & Wrapping & Fresh salads \\
\hline
\end{tabular}

Source: Food Process Engineering and Technology [101]. 
The European industrial sector has been analyzed in detail during the EU-DEEP project [5], in which some of the research for this dissertation was carried out. The first step in the project was to perform a segmentation of the industrial sector based on the way energy is used [6]. That segmentation confirmed that different factories devoted to the same activity also consume energy similarly. This fact is significant because it permits the extrapolation of the results obtained for a customer archetype to the whole sector, once specific consumption patterns have been evaluated. According to this premise, demand response requires the customer demand to be organized according to the specific uses or processes which generate demand for electricity. Therefore, the identification of the flexibility in energy consumption must necessarily be associated to a detailed analysis, based on physical and economic concepts, of the processes in each customer facility [2].

Table 22 shows different processes that could be found in the food industry, classified by type of activity. Likewise, examples of application for each one of these processes are also included.

\subsubsection{Flexibility Strategies in the Food Industry}

A number of general strategies focused on peak demand reduction in the food industry have been proposed in technical bibliography [100], although no examples are found on the application of such strategies to specific processes nor on the evaluation and assessment of the impact that they may have on the customer profile (let alone on the whole power system). Proposed strategies were classified by the Center for Industrial Research and Service of the lowa State University into the following four groups:

- Sequenced start-up

- $\quad$ Staggered or deferred usage 
- Sheddable loads

- Permanent reduction of ongoing loads

However, the three first actions could be included into a single group called "load shifting," according to the classification defined in section 2.3. In contrast, the fourth one could be considered as an efficiency action rather than a flexibility one, since the modification achieved on the customer's load curve is permanent. Moreover, this classification includes neither load reduction nor autonomous generation options. Thus, the following alternative classification is proposed to address these shortcomings, in accordance with the reasoning explained in section 2.3:

- Load shifting. This strategy is based on delaying or advancing some processes when involved activities can be performed without affecting the remaining processes. This strategy makes use of cheaper prices during shoulder and valley periods, concentrating consumption then when possible. For instance, part of the manufactured product could be stored in advance in order to supply the dependent processes during the flexibility action.

Load shifting can be applied to transformation and packaging processes, as analyzed in section 5.2.2.

- Load reduction. This strategy is possible when the energy supply of a process can be reduced or interrupted for a period of time in order to avoid consumption during on-peak periods. For example, it is applicable to most processes related to temperature maintenance at a site (preservation and storage), as the thermal inertia of the building can keep the temperature under control. Interruption of cooling production and 
distribution in working rooms or freezers is an example that has been successfully explored in the present dissertation.

- Autonomous generation. This is a variant of the load reduction strategy. The customer produces part of the electricity it uses onsite, so that a net reduction of the demanded power from the grid is produced without affecting the supply to the customer. This could be a reliable strategy when generators already exist for emergency situations. Indeed, its application is subject to the availability of generators in the facilities. These can be used to support flexibility since more power can be reduced from the grid.

\subsubsection{Significant Activities in the Food Industry}

Bibliography regarding the food industry [100], [101] examines different activities performed in a factory, from the initial reception of raw materials to the packaging of the final product. Such activities can be classified into two different groups:

- Production activities: They are processes that entail a transformation of raw material into different products or sub-products as part of the productive cycle.

- Auxiliary activities: The aim of such activities is to provide resources to the productive cycle, for instance compressed air, steam or lighting. However, these activities do not directly contribute to the productive cycle; rather, they are associated with the transformation of any type of energy that is not useful into another type of energy required by a different process. 


\subsubsection{Preparation}

According to the process classification established in Table 22, this section describes some of the most representative activities in the food industry, as well as the flexibility potential detected in each of these processes.

\subsection{Admission}

The preparation process begins when the raw material is admitted into the factory and prepared for subsequent stages in the production cycle. Customary loads that can be found in the admission section of a factory include conveyor belts, Archimedes screws, pumps and other transportation devices. Flexibility actions have not been considered for this process because raw material is transported in trucks (usually refrigerated) and tanks and must be admitted into the factory as soon as it is received, especially when an exhaustive temperature control is required. Additionally, the amount of energy consumed by this type of loads is very low.

\subsection{Separation of Raw Material}

At the separation stage, raw material is split up into its component parts, which may be a solid from a solid, a solid from a liquid, a liquid from a liquid, and so on. Common methods employed to separate materials can be the following:

- Sedimentation: Gravity is used to separate solids from fluids by decantation.

- Centrifugal sedimentation: Centrifuge devices are used to accelerate the sedimentation process.

- Flotation: The property of some particles to adhere to the surface of a bubble is used. When bubbles rise, wastes can be easily eliminated. 
- Filtration: A porous material is used to prevent undesired particles from passing through.

- Membrane separation: This is a variant of filtration, used when the particles to be filtered are too small to do so.

- Screening: Raw material is separated into different particle sizes.

- Air classification: A directed air current is used to separate heavy and light material.

- Electrostatic sorting: Solids are placed in a rotating drum that is electrically charged, so that charged particles are attracted to the drum. This is used to separate metals from raw material (seeds, tea...)

- Reflectance: Optical sensors are used to detect color differences on the surface of raw material. The use of this process to separate vegetables and fruits is growing.

- Expression: Oils and juices are extracted from their cellular structure by the use of mechanical forces.

- Extraction: Pods are removed from raw material in order to separate the useful material (seeds).

- Crystallization: This process is used to separate solids from liquids by forcing one of the components to crystallize.

- Peeling: This is a separation process to eliminate the covering from the raw material.

Shifting some of these processes or reducing their energy demand is usually quite complicated. Moreover, energy consumed by devices involved in separation is usually very low in comparison to other processes; hence, potential flexibility has not been considered. 


\subsection{Cleaning and Disinfection}

Although these activities are included within the preparation processes, cleaning and disinfection procedures affect all phases of food processing because hygiene is directly related to the quality and safety of obtained products. Therefore, operations related to cleaning and disinfection will be an integral part of the production cycle. Parts of the factory that must be subjected to cleaning or disinfections will include [101]:

- Raw materials

- Vehicles or other means of transportation used for raw materials.

- Equipment, tools and surfaces in contact with the product.

- Packaging materials

- Employees

- Buildings (walls, windows, floors, etc.)

- Air and water, both incoming and outgoing.

Large amounts of energy are used for cleaning purposes in food factories for pumping and heating water, but the main cost of this process is constituted by the amount of water used. In order to save water and energy, many food factories utilize the Cleaning in place method (CIP). This is based on a hydrodynamic system which distributes sanitizing water and detergent around the factory, so that cleaning activities can take place as soon as a production process finishes.

Cleaning tasks are usually performed at night and during non-operational periods, which are usually the cheapest. For that reason, no flexibility action has been considered for these processes. 


\subsubsection{Transformation}

\subsection{Size Reduction}

This process deals with adapting the size of raw material to the requirements of subsequent transformation processes. The size reduction process usually involves operations such as cutting, chopping, grinding or milling. Cutters and similar devices usually consume a significant amount of electrical energy, and the process could be shifted to more convenient periods. Consequently, the flexibility potential is very high.

\subsection{Mixing}

This is one of the most common activities in the food processing industry [100]. The aim is to completely mix the different ingredients of a product (solid, liquid or gas) until a homogenous blend is obtained.

The main energy source used for this process is electricity, since power mixers are driven by electric motors. Additionally, some products require mixing at high temperature, so a thermal energy source (steam, hot water, etc.) could be necessary. When no rigid temperature conditions are required, this could be a very flexible process; mixers could be interrupted and switched on again in cheaper periods.

\subsection{Extrusion}

This is one of the most widespread processes in the food industry [101]. It consists of forcing a material out of a narrow gap. Extrusion is a continuous process which requires little labor. Currently, food production factories use extrusion combined with heat transfer application, which is called "extrusion cooking." This process is usually very efficient since the amount of energy required by the product to modify its physical characteristics is applied directly, and intermediate stages are not required. Moreover, it 
is a very flexible process that could easily be shifted to different periods of time, for example, during cheaper valley periods.

\subsubsection{Preservation}

\subsection{Drying}

Drying is one of the oldest methods used for food preservation [101], based on the principle that microorganisms need water to survive.

This process consists of reducing the humidity level of a solid material by evaporation. Although different methods can be used for drying purposes, the most common is convection, when hot air flow is forced through the material which needs to be dried. The drying process should not be confused with other dehydration methods used for curing meat, by which water is eliminated from air by reducing the temperature of moist air; in this process, water is eliminated by condensation when the dew point temperature is reached.

Regarding flexibility, reducing the speed of the fans used to force the hot air to circulate inside the dryer could diminish the electricity demand for a short period of time. Nevertheless, flexibility would be applied to continuous dryers since temperatures and times are rigidly established, and they cannot be easily modified without affecting the quality of the product.

\subsection{Pasteurization and Sterilization}

Pasteurization uses heat at a relatively mild temperature (usually lower than $100^{\circ} \mathrm{C}$ ) in order to eliminate vegetative cells or microorganisms. Nevertheless, due to the limited range of temperatures used, it has almost no effect on spores. On the other hand, sterilization uses heat at high temperatures (over $100^{\circ} \mathrm{C}$ ) so that all types of microorganisms, including spores, are eliminated. Consequently, pasteurization provides 
food with short-term stability, while sterilization uses more energy but allows the food to be preserved for longer periods. Pumps are usually the only electrical load present in this process. Because temperatures are strictly controlled, no flexibility actions can be applied.

\subsection{Refrigeration}

Reducing the temperature of food does not eliminate microorganisms (this is only achieved by increasing temperature), but chemical reactions and biological processes are slowed down and, consequently, the damaging activity of microorganisms is neutralized.

Depending on the temperature that is used, technical bibliography [101] distinguishes between two different processes: chilling and freezing. The temperature range used for chilling is higher, usually between $0^{\circ} \mathrm{C}$ and $8^{\circ} \mathrm{C}$. In contrast, temperatures used in freezing are generally below $-18^{\circ} \mathrm{C}$. Logically, the amount of energy required for freezing is higher that for chilling, but the preserving action is stronger since part of the water becomes ice.

As discussed below in section 5.3.4.1, one of the most important uses of cooling in the food industry is the elimination of humidity from moist air, which is crucial in the manufacturing of products such as cured meat and fish. Moreover, refrigeration can be used for maintaining a required temperature in working rooms.

During the research performed for this dissertation, refrigeration was shown to be the most flexible process in factories where energy devoted to cooling production and distribution is high, especially for freezing and drying purposes. The milk and cheese industry (modeled in detail in the EU-DEEP project [5]) and the meat industry (studied in detail in this dissertation) constitute good examples for this application. 


\subsubsection{Packaging}

Packaging is the last stage in the chain of production performed in a factory, except when packaged products need to be stored in a controlled atmosphere (temperature and humidity), which requires a preservation process. The main objective of packaging is to contain and protect the final product after the productive cycle. Typical food packaging is made of metal, glass, paper or plastics.

Depending on the type of product, size, shape or physical state (solid, liquid or gas), this process could involve many different activities, whose energy consumption is not usually very high.

Despite the low energy consumption, this is normally a flexible process which can easily be shifted or interrupted for a period of time, and its duration depends on the storage capacity for the final product.

\subsection{Application of the Methodology to the Meat Industry}

\subsubsection{The Role of the Meat Industry Worldwide}

The meat and poultry industry is one of the most representative sectors among different industrial activities in diverse countries. It is the largest segment in U.S. agriculture [102], where the poultry and pork segment represents $16 \%$ of total production worldwide [103] (see Table 23). The share for the European Union is similar, at $18 \%$ of total global production. In the case of Spain, the production of different pork goods, such as cured ham or deli products, is well-recognized around the world. Spain produces $3 \%$ of total pork worldwide.

As an example, Figure 23 shows the share of energy consumption corresponding to the food industry in Canada. The most significant activity in energy terms is the meat industry, which represents $18 \%$ of total energy consumption in the national food industry. 
Table 23. Meat production around the world (2005), in thousands of tons

\begin{tabular}{lrrrr}
\hline \multicolumn{1}{c}{ Type of meat } & \multicolumn{1}{c}{ Spain } & \multicolumn{1}{c}{ EU } & \multicolumn{1}{c}{ US } & \multicolumn{1}{c}{ World } \\
\hline Beef \& Buffalo & 715 & 8066 & 11,243 & 62,748 \\
Poultry & 1104 & 10,853 & 19,105 & 81,781 \\
Mutton, Lamb \& Goat & 238 & 1156 & 85 & 12,579 \\
Pork & 3168 & 21,803 & 9383 & 98,927 \\
Others & 82 & 648 & 224 & 4.512 \\
Total & $\mathbf{5 3 0 8}$ & $\mathbf{4 2 , 5 2 5}$ & $\mathbf{4 0 , 0 3 9}$ & $\mathbf{2 6 0 , 5 4 7}$ \\
\hline
\end{tabular}

Source: FAOSTAT

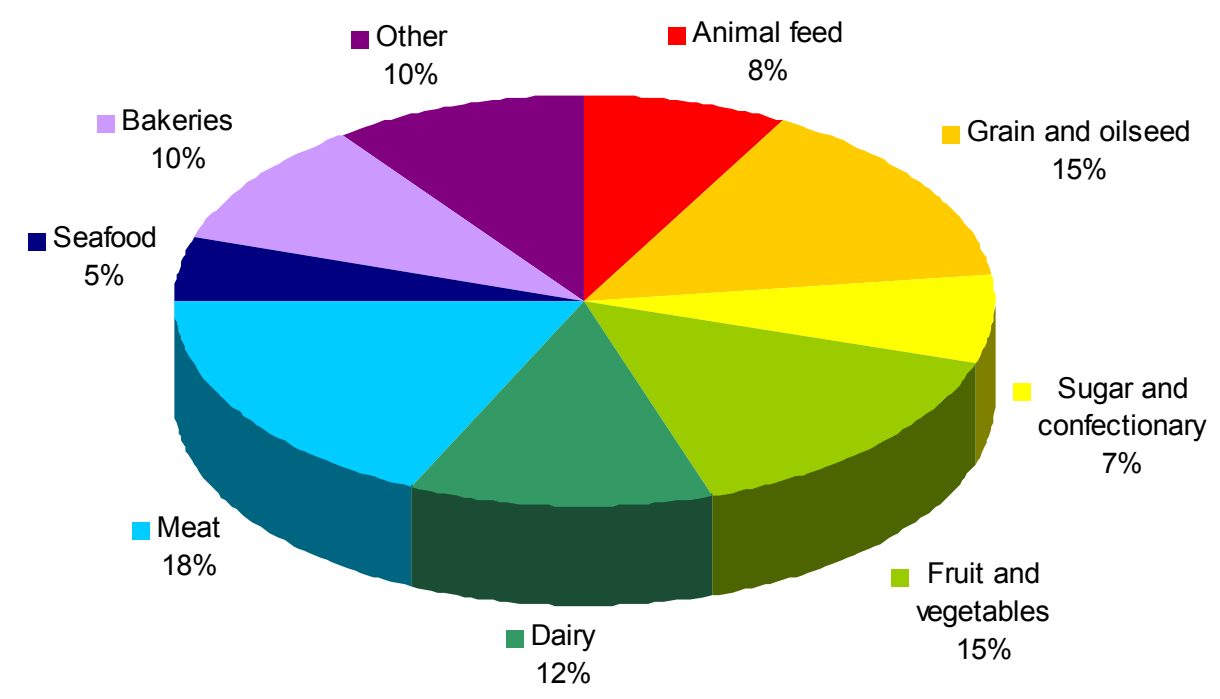

Figure 23. Use of energy in the food industry in Canada, 2007

The most significant sector in energy terms is the meat industry, with $18 \%$ of total energy consumption of this sector. It is interesting to note that only 4 different activities (meat, dairy, fruit \& vegetables and oilseed) make up $60 \%$ of the total consumption in this sector in Canada [104].

Energy use is considerable for this type of consumer, and the meat industry has been identified as one of the most suitable segments for demand response (DR) implementation [5], [6]. 


\subsubsection{Flexible Processes in the Meat Industry}

The types of processes carried out in the meat industry have been described in section 5.2.2, and these are common to the rest of the food industry. Heat, ventilation and cooling production loads are among the most energy consuming processes in the meat processing industry [3]. Electricity consumption is mainly used for cooling and ventilation, while fossil fuels such as natural gas or diesel are generally used for heating processes.

In the meat industry, ventilation usually uses about $35 \%$ of the total energy consumption, as shown in Table 24 for three of the studied cured meat factories in Spain. However, cooling production and distribution constitutes between $45 \%$ and $55 \%$ of the total final electricity consumption on working days [105], making this the most energy-intensive process for most consumers in this segment.

Table 24. Consumption of electricity (\% of total) in three different cured meat factories in Spain

\begin{tabular}{lrrr}
\hline & Factory 1 & Factory 2 & Factory 3 \\
\hline Cooling production and distribution & $46.2 \%$ & $51.6 \%$ & $52.8 \%$ \\
Ventilation & $35.2 \%$ & $34.2 \%$ & $35.8 \%$ \\
Lighting & $5.1 \%$ & $4.3 \%$ & $0.9 \%$ \\
Compressed air & $4.1 \%$ & $1.4 \%$ & $1.1 \%$ \\
Machinery & $5.5 \%$ & $5.3 \%$ & $4.7 \%$ \\
Others (offices, aux. services) & $3.9 \%$ & $3.2 \%$ & $4.7 \%$ \\
\hline TOTAL & $\mathbf{1 0 0 . 0 \%}$ & $\mathbf{1 0 0 . 0 \%}$ & $\mathbf{1 0 0 . 0 \%}$ \\
\hline
\end{tabular}

Source: FAOSTAT

According to the previous analysis, the flexibility potential for cooling production and distribution, as well as for ventilation, will be evaluated, since small actions on such processes could imply significant savings for the factory as a whole. Regarding these processes, the following potential flexibility actions have been analyzed: 
- The impact of interrupting the cooling production and distribution, since the thermal inertia of the building could maintain the required indoor temperature for a limited period of time.

- The variation of fan speed for a period of time to reduce the power demand of ventilation. Such reductions could mean significant energy savings, as the power demanded by fans is directly related to the cube of their speed.

In particular, both actions are related to the energy consumed in drying rooms (cooling and ventilation), so that energy reductions achieved by modifying the parameters of these processes will be evaluated, as well as the possible impact that such actions could have on the final quality of the product.

\subsubsection{Description of the Drying Process}

\subsubsection{Type of Drying Rooms}

The drying process in a cured ham factory takes place in specially designed chambers and requires accurate control of temperature, relative humidity and air speed [106]. Historically, the drying process was carried out in specific zones with a Continental Mediterranean climate. The process started in December, when temperature and humidity were low, and was completed in summer. Currently, artificial drying chambers reproduce such conditions permanently, so that a continuous production can be achieved.

Depending on the design of the factory, two different types of drying chambers can be found:

- Static chambers, where a constant value of humidity and temperature is maintained in each chamber according to the specific stage in the drying 
process. The ham is moved to different chambers upon completion of each stage.

- Dynamic chambers. The product remains in the same chamber during the entire drying process, and conditions of humidity and temperature are modified internally, according to a set drying curve schedule.

\subsubsection{Stages in the Drying Process}

Traditional Spanish dry-cured ham production begins by salting and storing fresh ham at a low temperature in order to stabilize the meat before drying commences [107]. The temperature of the drying air is gradually increased during the drying process to accelerate the reduction of water in meat and the development of the typical aged flavor. According to available bibliography [106], [108], and after studying in detail the process

of drying in different factories devoted to the production of Spanish cured ham, four drying stages can be identified for a typical plant, as shown in Figure 24.

- Post-salting stage. Temperature inside the chamber is set between $2^{\circ}$ and $5^{\circ} \mathrm{C}$, while humidity remains controlled between $80 \%$ and $90 \%$. The average duration of this stage is about six weeks, depending on the type of product. The amount of water contained in the meat is dramatically reduced during this stage, and the product loses $15-20 \%$ of its total weight.

- Drying stage. The meat loses about $10 \%$ of its weight during this phase of the process. Temperature is maintained at $15^{\circ}$ to $18^{\circ} \mathrm{C}$, and humidity is set at 70 $75 \%$. This stage usually takes three to five months. 


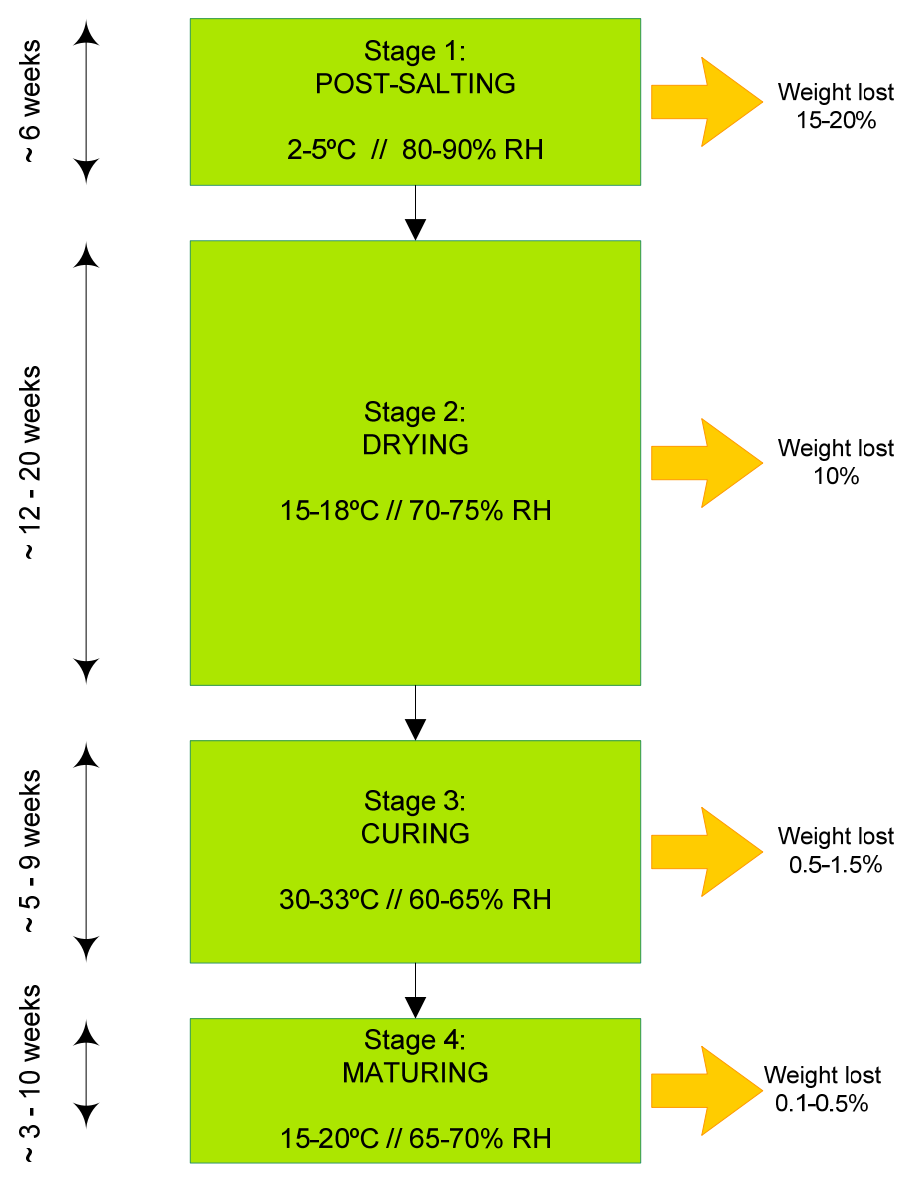

Figure 24. Drying processes in a typical cured ham factory

Four main stages were identified for a typical cured ham factory. The first stage requires the lowest temperatures and the highest levels of humidity, so this is the part of the process where the most water is extracted. The subsequent stages require higher temperatures and lower relative humidity values, so by the time the product reaches the last stage, it is almost completely dried.

- Curing stage. Temperature is higher $\left(30-33^{\circ} \mathrm{C}\right)$, and humidity decreases to about $65 \%$ during this stage, which typically lasts up to nine weeks. Ham loses between 0.5 and $1.5 \%$ of its weight in this phase.

- Maturing stage. The ham is left in a maturing chamber until the experts consider that the product is finished. Thus, the duration of this stage varies greatly depending on the individual factory and its location as well as the type and grade of the final product to be obtained. Accordingly, this stage could 
take anywhere from 20 to 70 days, depending on the type of final product and the amount of water it has already lost. Humidity is maintained below $70 \%$ and temperatures are set at about $15-20^{\circ} \mathrm{C}$.

In total, hams lose about $35 \%$ of their initial weight during the whole drying process.

\subsubsection{Psychrometric Analysis}

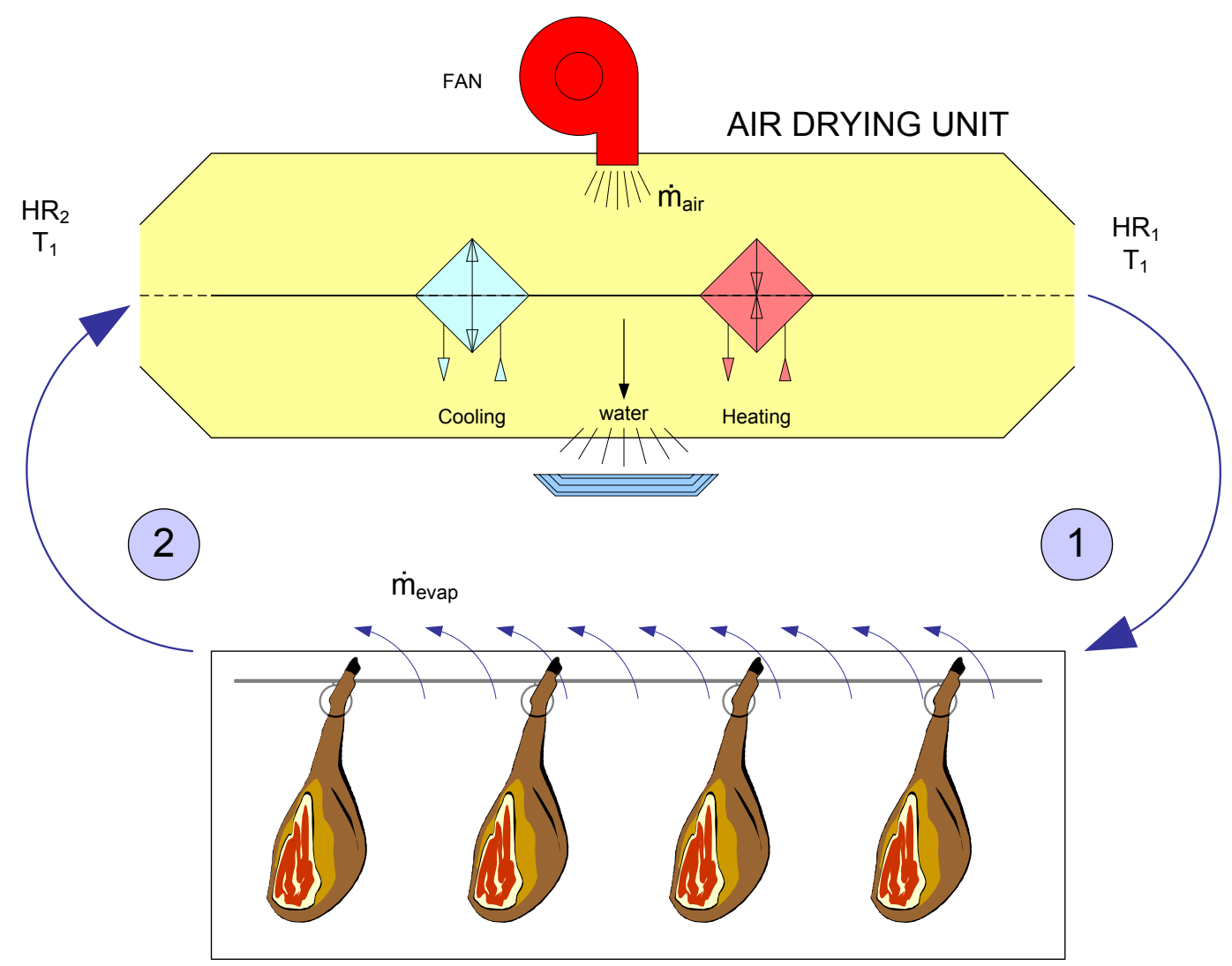

Figure 25. Meat drying process scheme

Dry air absorbs humidity emitted by the meat from point 1 to point 2 . Then, the moist air comes into the air drying unit, where the water is extracted by condensation, produced through the use of a cooling unit. After applying hot air to return the air to its initial temperature, the hot dry air returns to point 1 to restart the cycle. 
Maintaining controlled temperatures and humidity inside drying rooms is elemental to the process of drying in food production factories, so any action that implies a degradation of these parameters will be unacceptable. Taking this fact into account, flexibility actions carried out must guarantee that variations in those parameters are maintained within acceptable limits.

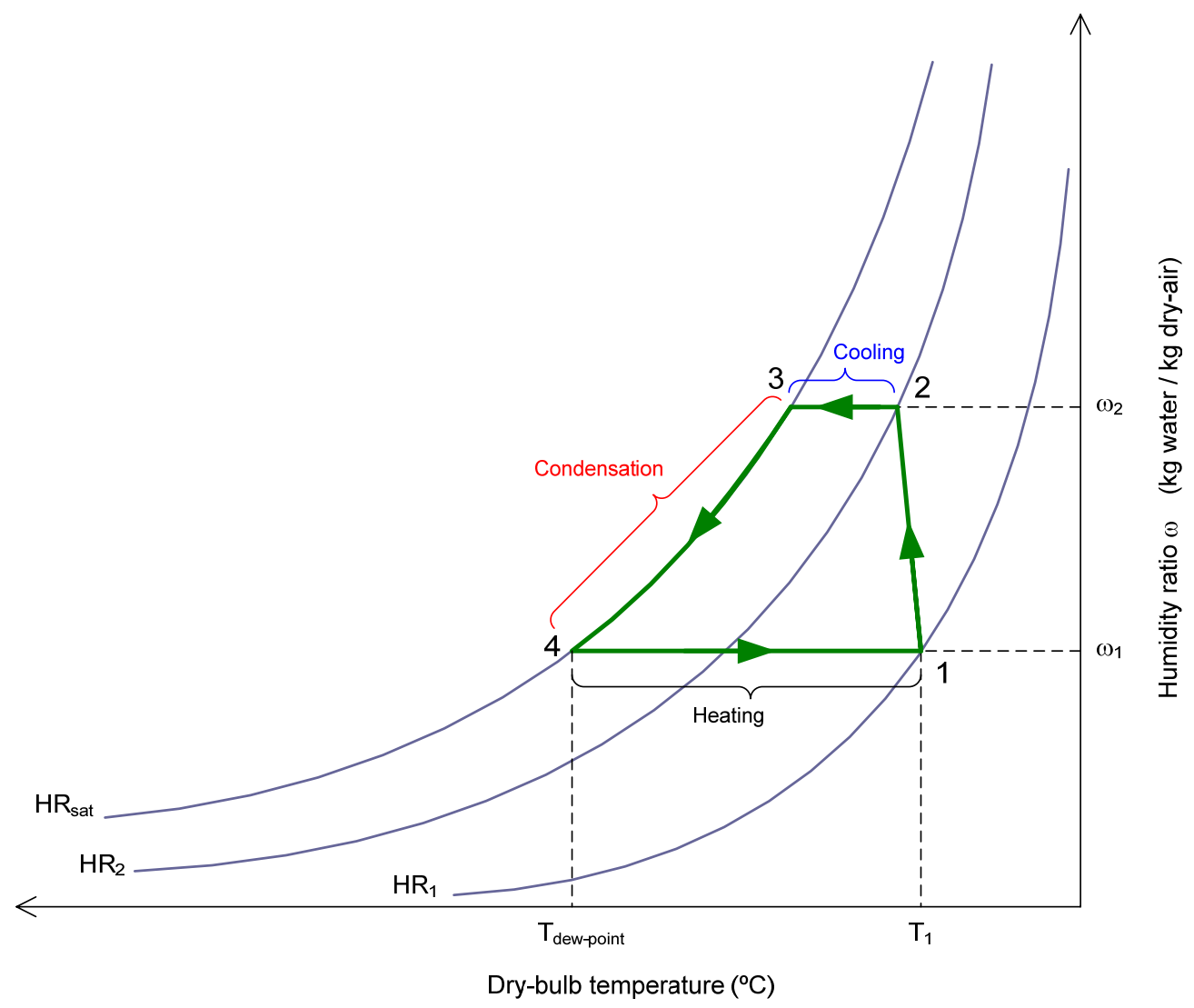

Figure 26. Psychrometric chart for a drying room

The figure represents dry-bulb temperature versus humidity ratio of air utilized for drying purposes. Air inside the drying chamber follows the cycle marked in green so that it is cooled until achieving the dew-point temperature in point 4 . Then, water is extracted by condensation, and the dry air is forced to pass through a heat exchanger, where it is returned to its initial temperature.

Figure 25 schematically represents how the drying process works in a meat drying room. In step 1, dry air comes into contact with the surface of the meat inside the drying room (point 1 to point 2), absorbing the humidity present on the surface of the 
meat. This results in the humidity ratio $\omega$ growing adiabatically from $\omega_{1}$ to $\omega_{2}$, as shown in Figure 26. When moist air enters the air drying unit, temperature is reduced (point 2 to point 3) until reaching dew point. Moisture condensation occurs when moist air is cooled to a temperature below its initial dew point. From point 3 to point 4 , the temperature decreases while the air drives the water out; since the humidity ratio is lower, the capacity of the air to hold the evaporated water is reduced. Dry air is heated again (point 4 to point 1 ) in order to maintain the temperature inside the drying room, leaving the air drying unit in the conditions found at point 1.

\subsubsection{First Strategy: Interruption of Cooling Production and Distribution in Drying Rooms}

\subsubsection{Use of Cooling in the Meat Industry}

Many different configurations can be found with regard to the use of cooling in the meat industry, depending on the configuration of the production and processes as well as the type of goods produced in each particular factory. However, after studying in detail the use of cooling in different factories located in Spain, where a wide range of different meat products are manufactured [4], four basic circuits for cooling production can be established for a typical meat production plant, as shown in Figure 27:

- Freezing line: This is used in freezing chambers to preserve the meat at a very low temperature. The primary temperatures for this type of circuit are usually between -35 and $-40^{\circ} \mathrm{C}$. Another different and dedicated circuit at a lower temperature may be available if a deep-freezing tunnel is used for freezing rather than preserving the meat; this is a common practice in slaughterhouses. 


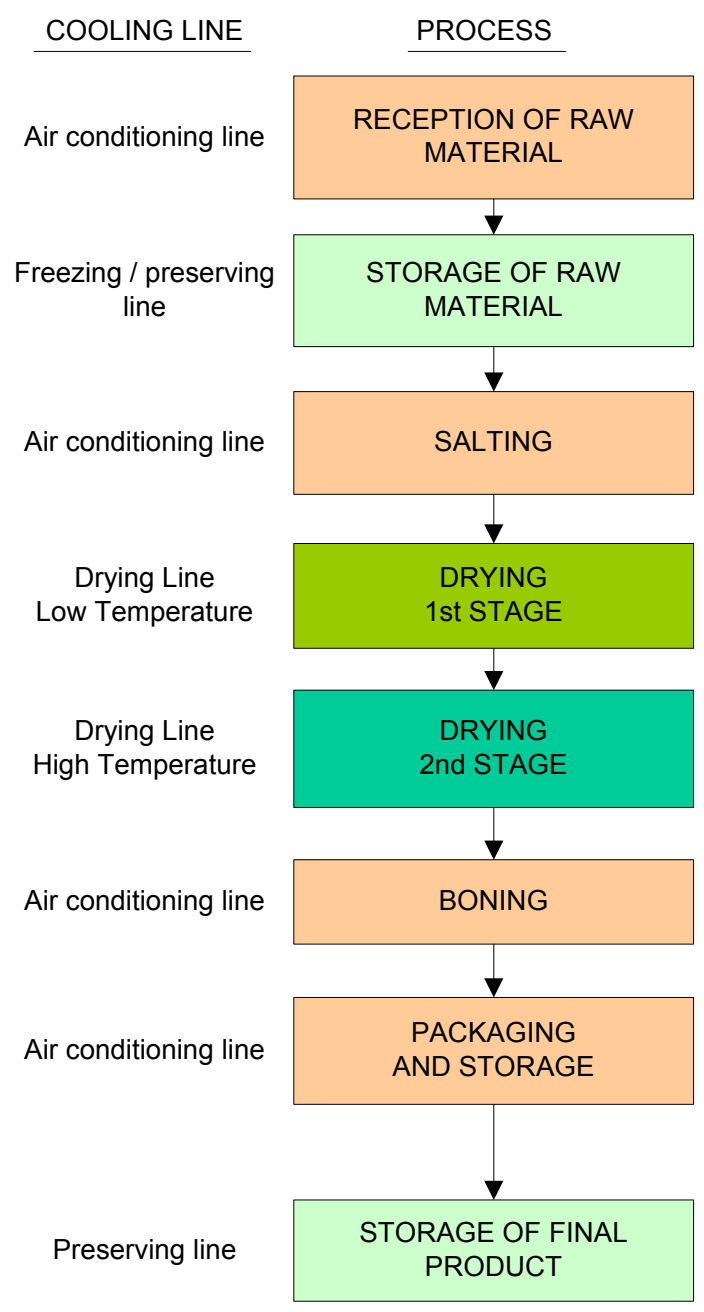

Figure 27. Scheme of processes in a typical cured meat products factory Four main cooling lines are present in a typical factory devoted to production of different meat products. They are, from the coolest to the warmest, the freezing line, the preserving line, the air conditioning line and the drying lines.

- Preserving line: When the aim of a chamber is to keep fresh meat rather than frozen meat, primary temperatures between -10 and $-15^{\circ} \mathrm{C}$ usually satisfy that requirement.

- Air conditioning line: Used for maintaining the required cooling conditions in working rooms. Values of primary temperature for this line vary from $0^{\circ}$ to $-5^{\circ} \mathrm{C}$ to keep the temperature of the room within a range varying from $5^{\circ}$ to $10^{\circ} \mathrm{C}$, depending on the use of the room. 
- Drying lines: In factories which produce cured meat products such as ham or deli meats, there are usually two specific lines for drying processes; these account for most of the electricity consumption in the plant. One of these lines, the Low Temperature Line, is set between -10 and $-5^{\circ} \mathrm{C}$, and can also be used as a preserving line. The second drying line, called the High Temperature Line, is adjusted between 0 and $-5^{\circ} \mathrm{C}$. Sometimes it is used for air conditioning purposes, although this option is less frequent. Both the high and low temperature lines, combined with other hot water lines, keep the temperature of drying rooms under control and reduce the level of humidity to levels mandated by the professionals in charge of the drying stage.

Table 25. Breakdown of electricity consumption in different cured meat production factories

\begin{tabular}{cccc}
\hline & \multicolumn{1}{c}{ Factory 1 } & Factory 2 & \multicolumn{2}{c}{ Factory 3 } \\
& $\begin{array}{c}\text { Continental } \\
\text { Mediterranean with } \\
\text { cold winter climate }\end{array}$ & $\begin{array}{c}\text { Continental } \\
\text { Mediterranean with hot } \\
\text { summer climate }\end{array}$ & $\begin{array}{c}\text { Warm Mediterranean } \\
\text { climate }\end{array}$ \\
\hline Freezing Chambers & - & $7 \%$ & $1 \%$ \\
Preserving Chambers & $11 \%$ & $49 \%$ & $10 \%$ \\
Drying Low Temp. & $45 \%$ & $36 \%$ & $41 \%$ \\
Drying High Temp. & $41 \%$ & $8 \%$ & $42 \%$ \\
Working Rooms & $3 \%$ & & $5 \%$ \\
\hline
\end{tabular}

Table 25 shows the breakdown of electricity consumption for three different factories which produce cured meat products in three places with different climates: northern (Continental Mediterranean with cold winter climate), western (Continental Mediterranean with hot summer climate) and central Spain (Warm Mediterranean 
climate). For this type of factory, drying processes usually consume the largest amount of energy, reaching values of $65-81 \%$ of total electricity consumption. The reason is that the cooling in drying rooms is aimed not at refrigeration, but reduction of the humidity in meat, achieved by lowering the temperature of moist air in contact with the meat to the dew point.

As the cooling process works continuously throughout the year, the load curve of the process will be flat, as shown in Figure 28. The figure has been obtained specifically, so that power demand is expressed in $\mathrm{kW} / \mathrm{ton}$.

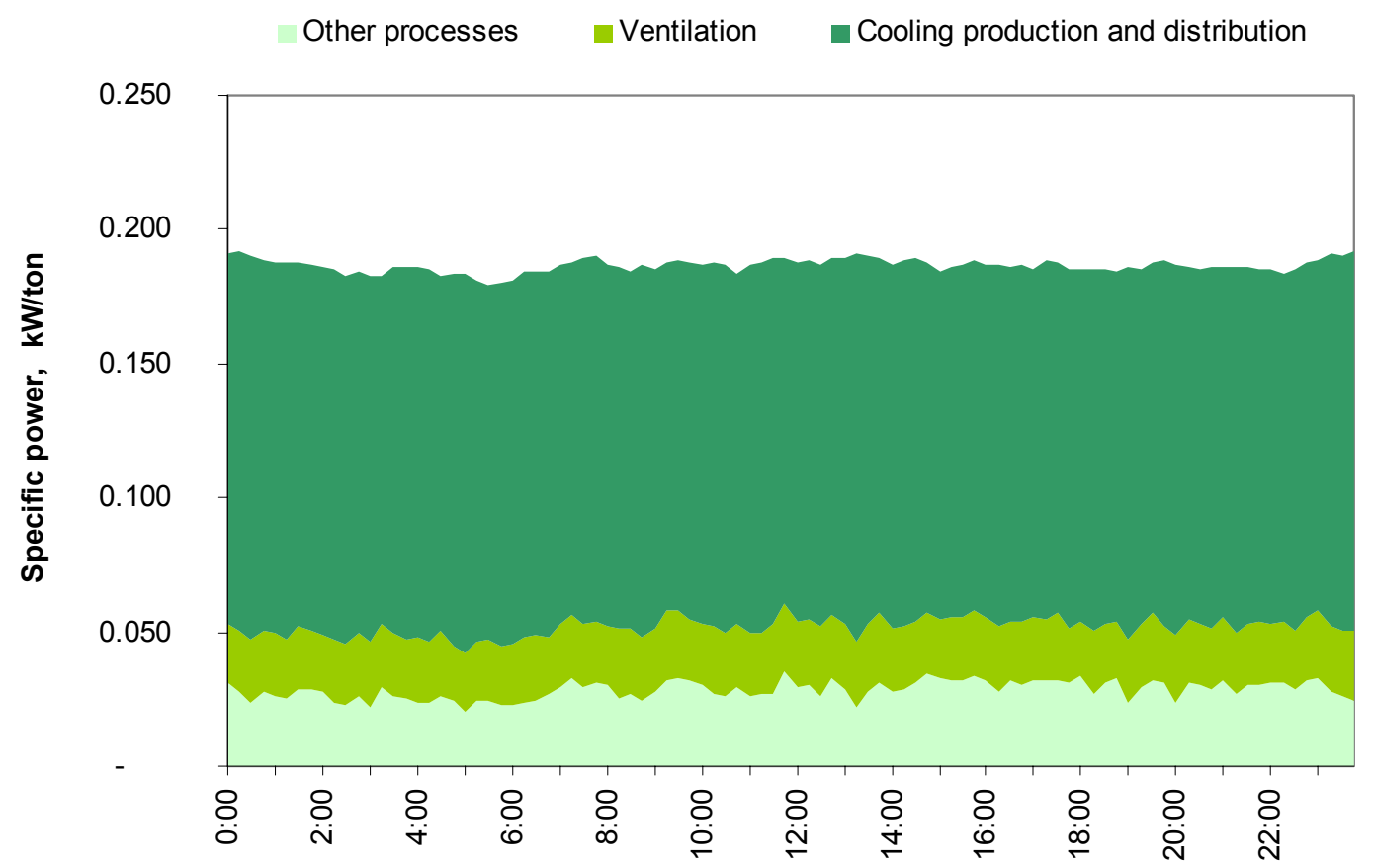

Figure 28. Typical load curve for a cured meat factory

The curve represents the typical power demand in a factory devoted to the production of cured meat, where three processes have been identified: cooling production and distribution, ventilation, and other processes, which include lighting, compressed air, machinery, etc. 


\subsubsection{Implementation of the Flexibility Action}

The proposed strategy is based on the interruption of the electricity supply used in cooling production so that the thermal inertia of the system can be used to keep both temperature and humidity within acceptable limits. Temperature and, consequently, the humidity ratio for point 4 in Figure 26 increases when cooling production is interrupted. Therefore, the duration of this action will depend on the stability which can be maintained in the product. Interruptions lasting up to two continuous hours can be acceptable for this type of product, as explained in Chapter 6. Similarly, the cooling activity will be more intense during the subsequent minutes after the interruption (payback period), so that point 4 will decrease until the set point is achieved once again.

According to these premises, a flexibility action with the characteristics included in Table 26 could be performed. A total of two interruptions a day could be activated, so that reductions for a period of up to four hours a day could be achieved. Customers have demonstrated the ability to perform the reduction within 15 minutes of advance notice.

Table 26. Identification parameters card of customer flexibility for strategy 1

\begin{tabular}{cl}
\hline Parameter & \multicolumn{1}{c}{ Value / Description } \\
\hline$\Delta \mathrm{P}_{\mathrm{R} 1}$ & $0.121 \mathrm{~kW} /$ ton \\
\hline$\Delta \mathrm{P}_{\mathrm{R} 2}$ & - \\
\hline$\Delta \mathrm{P}_{\mathrm{R} 3}$ & $0.023 \mathrm{~kW} /$ ton \\
\hline $\mathrm{T}_{\mathrm{AV}}$ & 4 hours a day \\
\hline $\mathrm{T}_{\mathrm{D}}$ & 2 hours \\
\hline $\mathrm{T}_{\mathrm{PR}}$ & - \\
\hline $\mathrm{T}_{\mathrm{RC}}$ & 1 hour \\
\hline $\mathrm{T}_{\mathrm{IA}}$ & 15 min \\
\hline
\end{tabular}




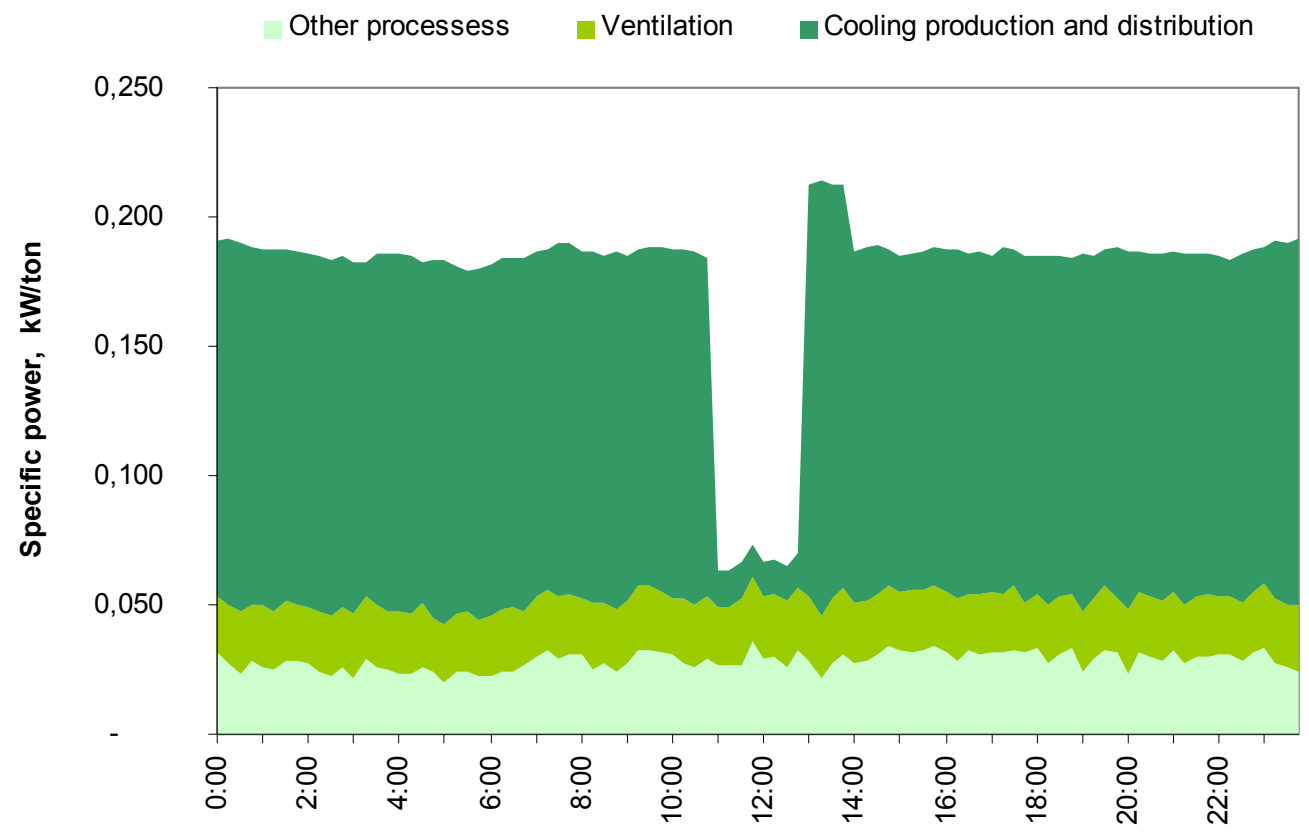

Figure 29. Effect of interrupting the cooling process in a typical cured meat factory An interruption is simulated in a typical cured meat factory according to the flexibility potential evaluated in the segment by switching off the cooling production and distribution for two hours. A reduction of about $90 \%$ in the process power demand is achieved, while a recovery period of one hour requires $16 \%$ extra consumption (from the baseline) of saved energy.

Figure 29 shows the effect of the interruption on the total load curve of the factory for a typical working day, where the strategy has been implemented from 11:00 am to 1:00 pm. Reductions up to $55 \%$ of the total power demanded by the factory are obtained.

\subsubsection{Second Strategy: Fan Speed Variation in Drying Chambers}

Fans forcing air through the drying units work intermittently, according to the drying plan established by experts for the proper development of the process. The action proposed here is based on the modification of the on-off sequences so that the fans work longer but at a lower speed, maintaining the total amount of water extracted from the drying chamber. 
Customers have frequently rejected reduction of fan speed when it has been proposed as an efficiency action since permanent reductions could stratify the air inside the chamber to the detriment of product quality. Consequently, the action proposed in the present dissertation is not the permanent modification of speed, but rather a temporary adjustment made during certain periods of time when it could be required by the system operator or advisable to avoid high market prices.

This strategy has only been studied in factories where drying chambers are static, since otherwise the drying process takes place continuously and the modification of speed of fans could entail other undesirable effects.

\subsubsection{Modeling}

The following equation applies when the mass balance conditions are reached:

$$
\dot{m}_{\text {evap }}=\left(\omega_{2}-\omega_{1}\right) \cdot \dot{m}_{\text {air }}
$$

where:

- $\dot{m}_{\text {evap }}$ is the mass flow of evaporated water from the surface of the ham $(\mathrm{kg} / \mathrm{s})$;

- $\dot{m}_{\text {air }}$ is the dry airflow required to evacuate $\dot{m}_{\text {evap }}$ at nominal speed $N$ $(\mathrm{kg} / \mathrm{s})$;

- $\omega_{1}$ is the humidity ratio at the exit of the air drying unit (kg water / kg dryair); and

- $\omega_{2}$ is the humidity ratio at the entrance of the air drying unit (kg water / $\mathrm{kg}$ dry-air). 
$\omega_{2}$ and $\dot{m}_{\text {air }}$ are the unknowns, and $\omega_{1}$ can be obtained from the initial conditions by means of the known variables $T_{1}$ and $\mathrm{HR}_{1}$ in the psychrometric diagram shown in Figure 26.

$$
\begin{aligned}
& \dot{m}_{\text {evap }} \text { can be calculated as follows: } \\
& \dot{m}_{\text {evap }}=\frac{M_{\text {chamber }}}{t_{d r y}}
\end{aligned}
$$

where:

- $\mathrm{M}_{\text {chamber }}$ is the amount of water evacuated from the chamber during the drying stage (kg water); and

- $t_{d r y}$ is the duration of the drying stage(s)

If the energy balance during a drying stage is achieved, it is easy to verify that the amount of energy absorbed by the air during the drying process is equal to the amount of energy transferred by the ham, as stated below:

$$
Q_{\text {air }}=Q_{\text {ham }}
$$

$Q_{\text {ham }}$ is the heat transferred by the ham during the drying stage $(J)$, and $Q_{\text {air }}$ is the heat acquired by the air during the drying stage $(\mathrm{J})$. $Q_{\text {air }}$ is the difference between the energy of the water-air mixture at the exit and at the entrance of the drying unit:

$Q_{\text {air }}=\dot{m}_{\text {aire }} \cdot\left[\left(h_{2}-h_{1}\right)-\left(\omega_{2}-\omega_{1}\right) \cdot h_{f 2}\right]$ 
On the other hand, the amount of energy transferred by the ham to the air $\left(Q_{\text {ham }}\right)$ can be calculated as the product of the air mass flow and the specific enthalpy of water evaporation in the ham:

$$
Q_{\text {ham }}=\dot{\bar{m}}_{\text {evap }} \cdot h_{f g}
$$

$\mathrm{h}_{\mathrm{fg}}$ is the specific enthalpy of water evaporation in the ham; it is constant and equal to $2.4 \cdot 10^{6} \mathrm{~J} / \mathrm{kg}$ for this range of temperatures [109].

$\mathrm{h}_{2}$ and $\dot{m}_{\text {air }}$ can be obtained by combining the last three equations. The specific enthalpy $h_{2}$ is related to $\omega_{2}$ according to the psychrometric chart, so it is possible to establish a system of two equations with two unknowns to obtain the airflow $\dot{m}_{\text {air }}$ required to extract all the water from the drying chamber.

\subsubsection{Theoretical Evaluation of the Strategy}

The computation of boundary limits on possible savings with different operation conditions can be done by means of the fan performance equations. This process can be summarized according to the following simple relationships linking fan capacity, speed and power:

- The airflow volume is directly proportional to the fan speed.

- The power required by fans is proportional to the cube of the fan speed [110].

If fan speed were to be reduced, the duration of the ventilation cycle would need to be increased so as not to reduce the total amount of air which is required to remove all the water transferred by the ham. The speed reduction would be achieved if fans 
were working at a reduced regime for a longer time, which happens when the duration of the cycle is limited between $t_{\text {nom }}$ and $t_{\text {dry. }}$. Consequently, the new airflow required to evacuate all the water at a reduced regime is calculated as follows:

$$
\dot{m}_{\text {air }}^{\prime}=\dot{m}_{\text {air }} \cdot \frac{t_{\text {nom }}}{t_{\text {red }}} \quad t_{\text {red }} \in\left(t_{\text {nom, }} t_{d r y}\right]
$$

where $t_{\text {nom }}$ and $t_{\text {red }}$ denote the duration of the ventilation during the drying stage at nominal and reduced speed, respectively, and $\dot{m}_{a i r}^{\prime}$ is the dry airflow required to evacuate $\dot{m}_{\text {evap }}(\mathrm{kg} / \mathrm{s})$ at reduced speed.

Thus, the value of the reduced speed to evacuate all the water from the chamber is calculated using the following equation:

$$
N^{\prime}=N \cdot \frac{\dot{m}_{\text {air }}^{\prime}}{\dot{m}_{\text {air }}}
$$

$\mathrm{N}$ and $\mathrm{N}^{\prime}$ are the nominal and reduced fan speeds in the drying chamber, respectively, expressed in $\mathrm{rad} / \mathrm{s}$.

The power demanded by one fan after reducing its speed $\left(P_{\text {fan }}^{\prime}\right)$ is obtained from the relationship between both nominal and reduced speed as well as the value of the nominal electrical fan power $\left(P_{f a n}\right)[110]$ : 


$$
P_{f a n}^{\prime}=P_{f a n} \cdot\left(\frac{N}{N^{\prime}}\right)^{3}
$$

The total amount of energy consumed during the drying stage at nominal conditions can be calculated by means of the following equation:

$$
E_{\text {nom }}=n_{\text {fan }} \cdot P_{\text {fan }} \cdot t_{\text {nom }}
$$

where $E_{\text {nom }}$ is the energy consumed by fans in a drying chamber at nominal speed and $\mathrm{n}_{\mathrm{fan}}$ is the number of fans in the drying room. The total amount of energy consumed at a reduced regime $\left(E_{\text {final }}\right)$ can be similarly evaluated by substituting the power value by the figure obtained in the previous expression, and the time by the duration of the drying stage, since ventilation will work continuously:

$$
E_{\text {final }}=n_{f a n} \cdot P_{f a n}^{\prime} \cdot t_{\text {red }}
$$

The energy savings $E_{\text {saved }}$ are the difference between the solutions of the last two equations:

$$
E_{\text {saved }}=E_{\text {nom }}-E_{\text {final }}
$$

\subsubsection{Implementation of the Flexibility Action}

The reduction of fan speed for a short period of time also reduces the total power

demanded by such devices because the real power demanded by a fan is proportional 
to its cubed rotation speed. Hence, a large amount of energy could be saved if actions to modify this parameter are carried out.

As detailed in Chapter 6, reductions of speed in static chambers used for curing meat products have been evaluated. Our strategy proposes evaluating the required reduced speed at which fans should rotate in order to evacuate the same amount of water from the drying chamber, and shortening the "off" period during the fan sequence to make up for the reduced air current. The net effect in the load curve will be a reduction of demanded power during the period of time that fans are working at reduced speed.

It is important to point out that no recovery effect is produced, because fans are working for longer although at reduced speed. All the water is extracted from the chamber, so it is not necessary to recover any production or requirement after the implementation of the strategy.

Reductions of two hours are proposed, at a speed which necessitates fan operation for $80 \%$ of the time instead of the usual $50 \%$ in drying chambers; the results shown in Table 27 are obtained. Such reductions could be repeated after two hours of normal operation, so a total of 12 hours at a reduced regime could be achieved during one day. The customer could activate the action in only 15 minutes.

Table 27. Ratios of speed, consumption and power increment in drying chambers

\begin{tabular}{cccc}
\hline $\begin{array}{c}\text { Drying chamber I } \\
\text { stage }\end{array}$ & N/N' & $\begin{array}{c}\text { Ratio of } \\
\text { consumption } \\
\%\end{array}$ & $\begin{array}{c}\Delta \text { power } \\
\%\end{array}$ \\
\hline Post-salting stage & 1.6 & $62 \%$ & $-56 \%$ \\
Drying stage (I) & 2.0 & $26 \%$ & $-68 \%$ \\
Drying stage (II) & 2.3 & $5 \%$ & $-73 \%$ \\
Curing stage (I) & 2.7 & $6 \%$ & $-78 \%$ \\
\hline
\end{tabular}


In accordance with the above, the proposed flexibility action would have the following characteristics:

Table 28. Identification parameters card of customer flexibility for strategy 2

\begin{tabular}{cl}
\hline Parameter & \multicolumn{1}{c}{ Value / Description } \\
\hline$\Delta \mathrm{P}_{\mathrm{R} 1}$ & $0.014 \mathrm{~kW} / \mathrm{ton}$ \\
\hline$\Delta \mathrm{P}_{\mathrm{R} 2}$ & - \\
\hline$\Delta \mathrm{P}_{\mathrm{R} 3}$ & - \\
\hline $\mathrm{T}_{\mathrm{AV}}$ & 12 hours a day \\
\hline $\mathrm{T}_{\mathrm{D}}$ & 2 hours \\
\hline $\mathrm{T}_{\mathrm{PR}}$ & - \\
\hline $\mathrm{T}_{\mathrm{RC}}$ & - \\
\hline $\mathrm{T}_{\mathrm{IA}}$ & $15 \mathrm{~min}$ \\
\hline
\end{tabular}

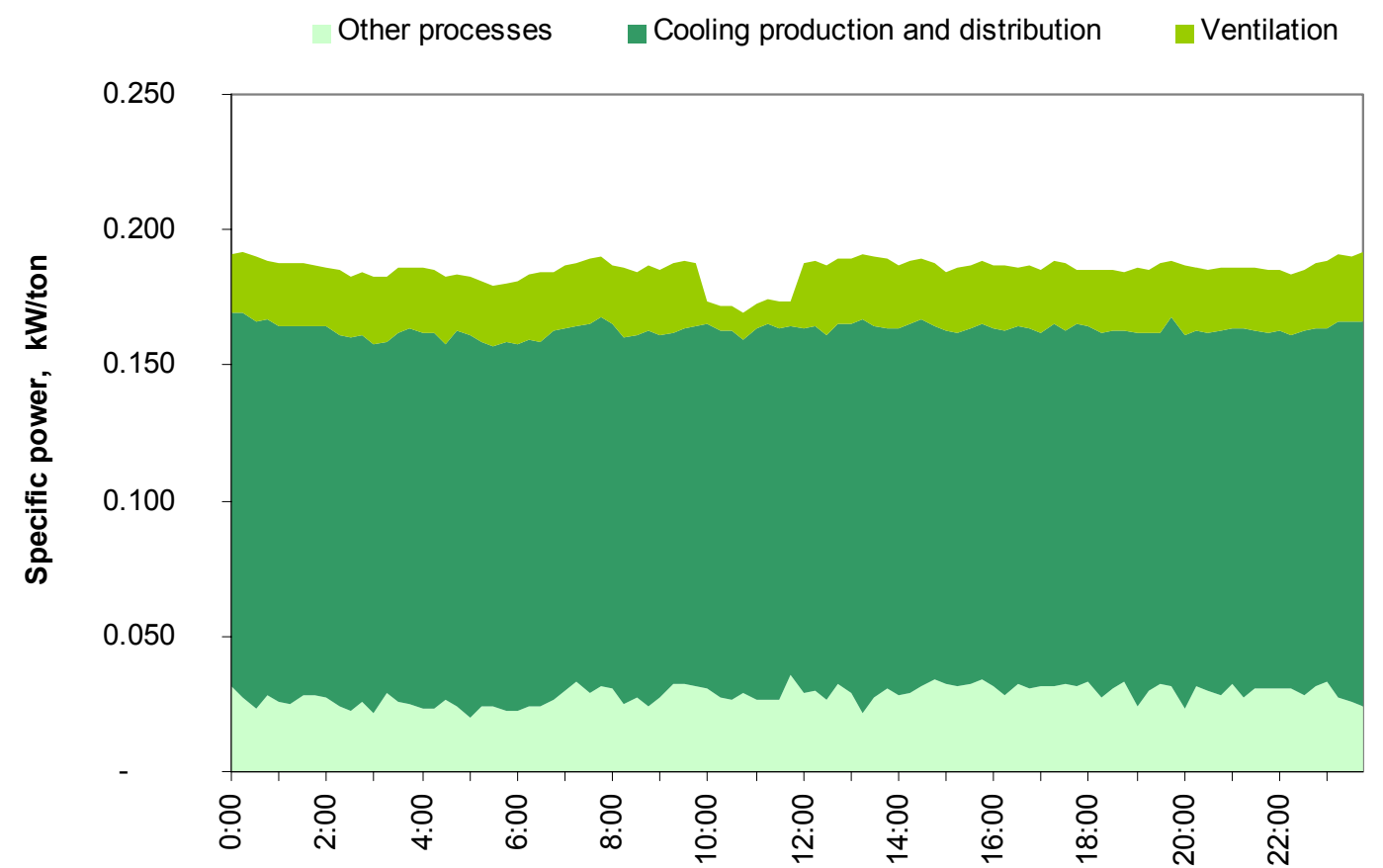

Figure 30. Effect of reducing fan speed in drying chambers at a cured meat factory A reduction of fan speed in drying chambers has been simulated in a typical cured meat factory according to the flexibility potential evaluated in the segment. A global reduction of about $60 \%$ of the power demanded by the process is achieved for one hour, which translates to $0.014 \mathrm{~kW} /$ ton on average. 
The effect of a two-hour reduction on the total load curve is presented in Figure 30 , where this strategy has been simulated from 10:00 to 12:00 on a typical working day. During hours of application, the peak power demanded by the customer is reduced by about $8 \%$.

\subsection{Conclusions of the Chapter}

The methodology designed in previous chapters for the identification of flexibility potential and the definition of DR products has been applied to the food industry sector in this chapter, and the DR potential in this sector has been assessed. Customers may reduce their energy consumption during certain periods of time and thereby obtain an appreciable profit.

This chapter uses a novel approach to define and evaluate flexibility actions in a sector where production processes have traditionally been considered very sensitive to the supply conditions and directly related to the quality of the final product. This fact has traditionally made customers reticent to change any element or parameter of those processes.

Flexibility is attained by two different strategies, which have been evaluated in this energy-intensive customer segment. The result is decisively positive: Customers are able to achieve daily energy savings of up to $6 \%$ without compromising product quality. Likewise, for electricity operators, peak reductions of about $55 \%$ and $8 \%$ in the total load curve can be achieved after applying both strategies.

It is important to point out that results obtained for the meat industry can easily be extrapolated to any other segment where the same type of processes are used. Consequently, different segments of the food industry, including dairy product manufacturing or seafood production (where cooling and ventilation are used for drying purposes), can apply the proposed strategies with the same profitable results. 
The strategies proposed in the present document were technically evaluated by using physical models and historical data registered in customers from the meat industry. Subsequently, these strategies were physically tested and validated in a cured ham factory located in Spain, whose energy consumption during ventilation processes and cooling production and distribution is very high. The next chapter shows empirical evidence on the effect that the application of the proposed flexibility actions has on real customers. 


\section{CHAPTER 6 :}

\section{VALIDATION TESTS IN A CURED HAM FACTORY IN SPAIN: TECHNICAL EVALUATION}

\subsection{Chapter Overview}

The effectiveness of actions designed and justified in the previous chapter, including the impact that flexibility may have on the quality of the product, has been validated in an industrial cured ham factory in Spain, as will be described in this chapter.

The validation of the first strategy proposed in Chapter 5, based on the interruption of cooling during peak hours, has been divided into two phases. The first phase consists of a pre-evaluation of flexibility applied to the part of the cooling system

(chillers and pumps) that supplies service to the drying rooms. This represents $37 \%$ of total electricity consumption in the factory and $31.5 \%$ of the cooling consumption. During this phase, daily interruptions of one hour were performed for one week. Once the effectiveness of this action was validated, a second and more intensive campaign of interruptions was carried out, and daily interruptions of four hours, two in the morning and two in the afternoon, were applied.

Regarding the second proposed strategy, based on the fan speed reduction in drying rooms, four different static chambers were studied in detail according to the design conditions in the considered factory, and a psychrometric analysis of each chamber was performed, according to the modeling method developed in section 5.3.5.1. 


\subsection{Validation of First Strategy}

\subsubsection{Pre-Evaluation}

The season selected for the pre-evaluation stage was the third week of January, 2010, as January and February have the highest on-peak prices for electricity according to the customer supply contract. Tests consisted of one-hour interruptions per day (12:00-1:00 pm), as shown in Figure 31, where the load curve of one day where flexibility was applied is compared to the profile for the previous day, when no interruption was performed.

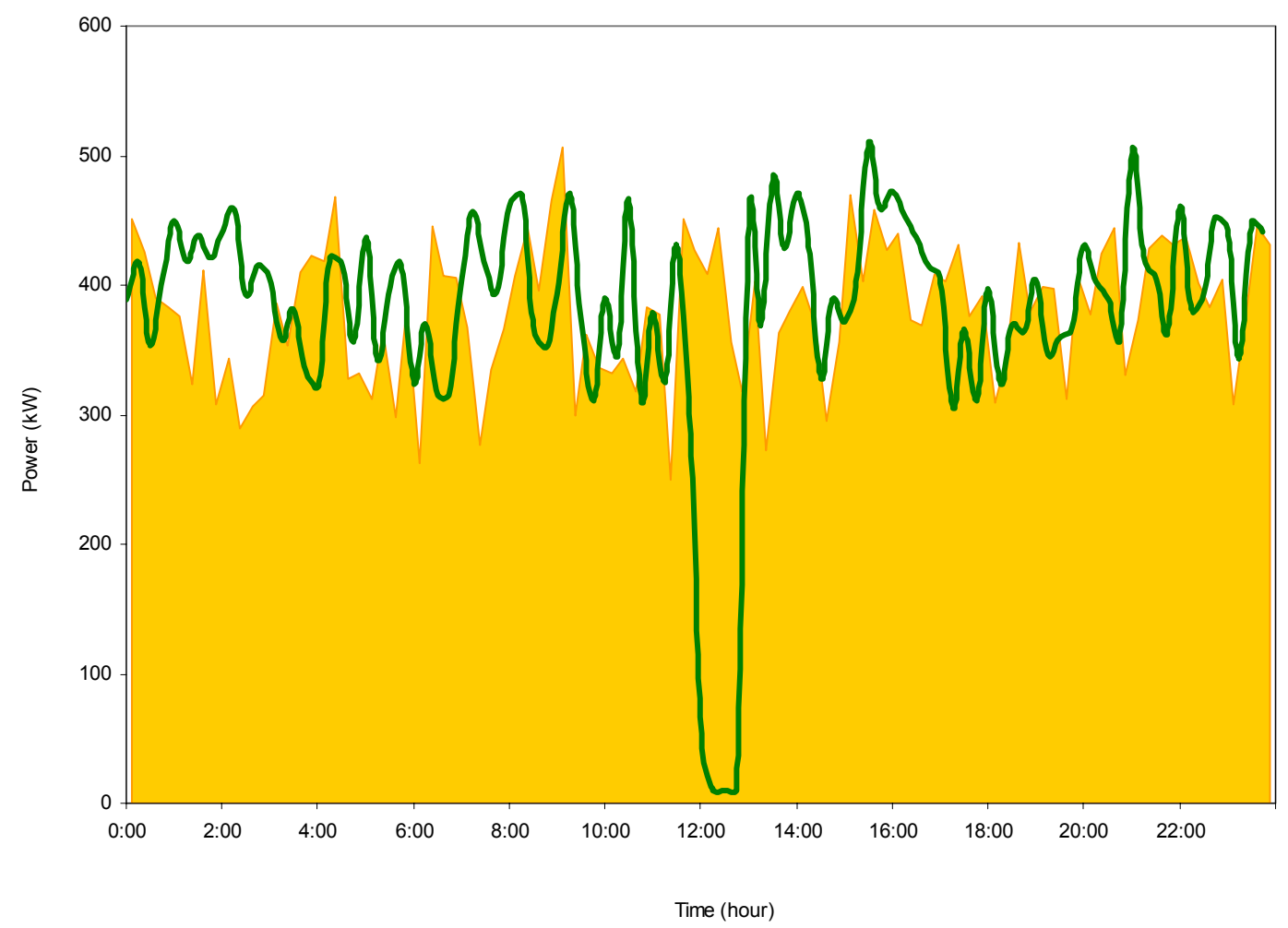

Figure 31. Pre-evaluation test performed in a cured ham factory

This figure shows a comparison between the load curve of two consecutive working days where flexibility was (green line) and was not applied (orange area).

The evolution of humidity and temperature was registered in order to ensure that these parameters were maintained within acceptable limits. Table 29 and Table 30 show this evolution, registered separately in four different drying rooms. 
Table 29. Variation of humidity during the test in drying rooms

\begin{tabular}{|c|c|c|c|c|c|}
\hline \multicolumn{2}{|c|}{ Humidity (\%) } & \multicolumn{4}{|c|}{ Time } \\
\hline Room & Reference & $12: 00$ & $12: 20$ & $12: 40$ & $13: 30$ \\
\hline Room A & 72.5 & 68.3 & 72.7 & 72.3 & 71.5 \\
\hline Room B & 72.0 & 70.3 & 74.3 & 75.3 & 72.3 \\
\hline Room C & 75.0 & 75.3 & 80.7 & 81.3 & 80.8 \\
\hline Room D & 80.0 & 77.3 & 80.3 & 81.8 & 78.3 \\
\hline
\end{tabular}

These tables show that variations obtained during the test for the different rooms were lower than $8 \%$, within the range of usual deviations in these parameters and therefore acceptable to the factory's quality technicians. The measurement taken at 13:30 shows that the set point values are restored just half an hour after the interruption ends.

Table 30. Variation of temperature during the test in drying rooms

\begin{tabular}{|c|c|c|c|c|c|}
\hline \multicolumn{2}{|c|}{ Temperature $\left({ }^{\circ} \mathrm{C}\right)$} & \multicolumn{3}{|c|}{ Time } & \multirow[b]{2}{*}{ 13:30 } \\
\hline Room & Reference & $12: 00$ & $12: 20$ & $12: 40$ & \\
\hline Room A & 30.0 & 27.0 & 28.3 & 29.3 & 27.8 \\
\hline Room B & 18.0 & 18.3 & 18.5 & 18.5 & 18.3 \\
\hline Room C & 8.0 & 8.0 & 8.7 & 8.7 & 8.2 \\
\hline Room D & 4.0 & 3.7 & 3.7 & 4.2 & 4.0 \\
\hline
\end{tabular}

By applying the methodology detailed in section 3.6.1, we can estimate that power reductions during on-peak periods are about $22.9 \%$ of the total demand of the factory. This means that savings of $338 \mathrm{kWh}$ can be achieved for one hour (including the additional consumption during the recovery period, which is estimated at $58 \mathrm{kWh}$ ), or a reduction of $3.6 \%$ in the consumption of the process and $1.2 \%$ in the total electricity consumption of the factory on a working day. If this reduction is extrapolated to the whole factory, a total potential of $52.6 \%$ is possible, given that cooling is responsible for $85 \%$ of total consumption, and the considered cooling system represents $37 \%$ of total electricity consumption (or $31 \%$ of total cooling). 


\subsubsection{Campaign of Interruptions}

After proving the effectiveness of proposed actions, a more intensive campaign of interruptions was performed. During February 2010, two daily interruptions of two hours each were performed on working days. Figure 32 shows different daily load profiles when interruptions were performed, as well as an average profile and the standard deviation, represented below.

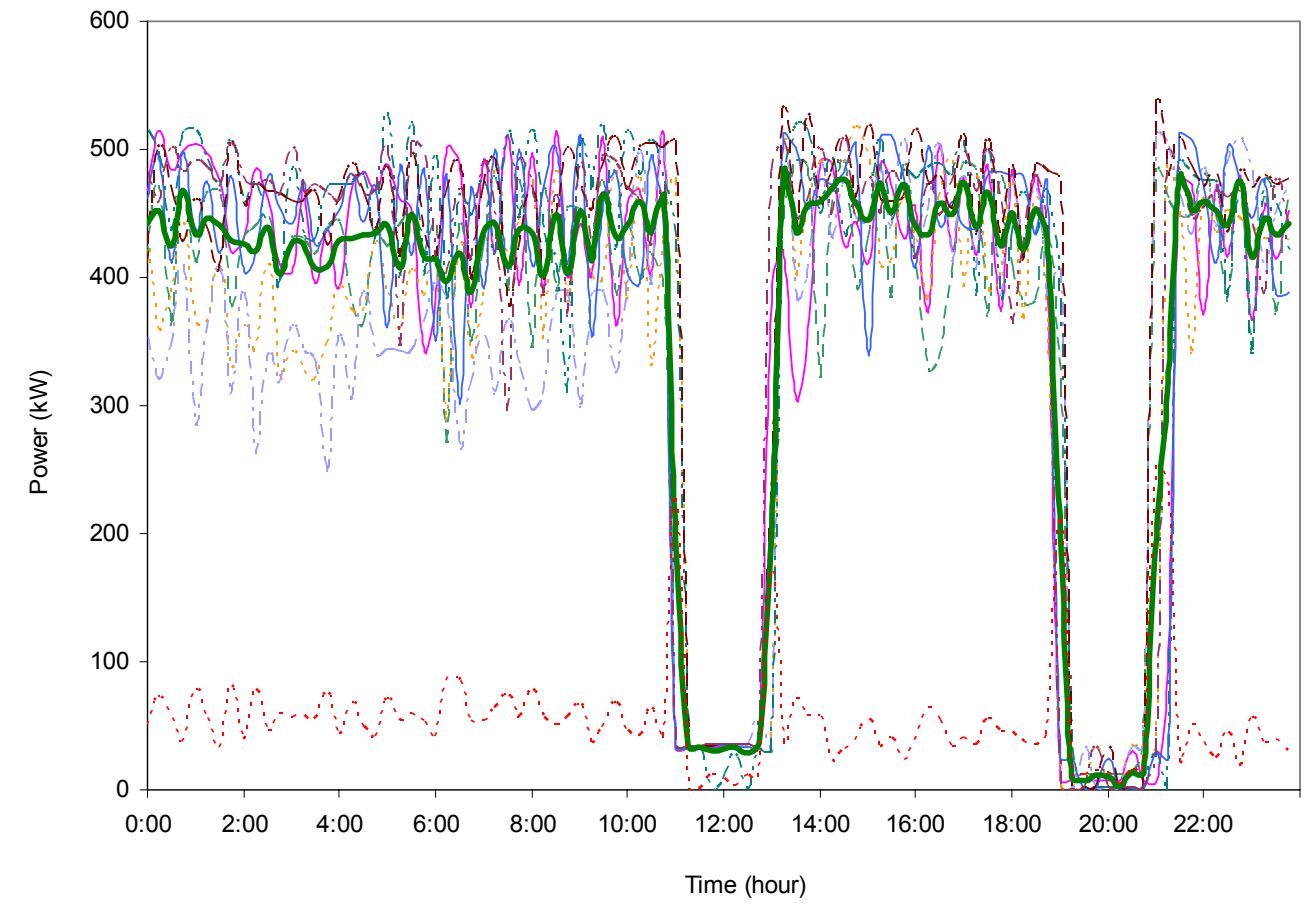

Figure 32. Load curves obtained during the campaign of interruptions

The figure shows the measured electricity profiles of the cooling process during days of the campaign of interruptions performed in a cured ham factory in February 2010.

Interruptions were carried out during on-peak periods, which are established in the contract from 10:00 am to $1: 00 \mathrm{pm}$ and from 6:00 pm to 9:00 pm in December, January and February. Because daily interruptions of six hours were considered unacceptable by the customer, only the last two hours of each peak period were used for flexibility purposes. Consequently, the reconnection of cooling devices took place during 
shoulder periods when prices were lower. As illustrated in Figure 32, the energy saved during each interruption is much higher than that consumed during the recovery period.

The application of these actions allowed the customer to reduce about $23 \%$ of the power peak required by the factory during the reduction, saving about $1555 \mathrm{kWh}$ every working day in February, equivalent to a $1.5 \%$ reduction in monthly electricity consumption. If these results are extrapolated to the whole cooling system, a reduction of $52.8 \%$ of the total power peak in the factory can be achieved.

\subsection{Validation of Second Strategy}

In order to validate this strategy, based on the reduction of fan speed, four different drying rooms were studied in detail according to the design conditions of the considered factory. These drying rooms are characterized as "static chambers," as described in section 5.3.3.1, meaning that a constant value of humidity and temperature is maintained in each chamber depending on the specific stage of the drying process, and the ham is moved to different chambers upon completion of the preceding stage.

\subsubsection{Description of Considered Drying Chambers}

The first chamber is used in the post-salting stage, which is the first phase of the sequential drying process. This chamber has 30 drying units installed on the ceiling of the room. When the post-salting process is completed, the meat is transferred to another chamber, called the "first drying chamber," where the meat remains for a set period of time. Afterwards, the ham is moved to the "second drying chamber," where the second stage of the process is carried out. Finally, the meat is moved to a fourth chamber, which is used for curing the meat. The first drying chamber has 30 drying units, while the second drying chamber and the curing chamber have 12 drying units each. The chambers used in the maturing stage were not considered for this phase of the study 
because a pre-evaluation study resulted in much lower savings than in the other ones. Table 31 shows the set point parameters for each one of these chambers:

Table 31. Set point parameters for different drying chambers in a cured-ham factory

\begin{tabular}{ccccc}
\hline $\begin{array}{c}\text { Drying chamber I } \\
\text { stage }\end{array}$ & $\begin{array}{c}\text { Set point } \\
\text { temperature } \\
{ }^{\circ} \mathrm{C}\end{array}$ & $\begin{array}{c}\text { Set point } \\
\text { humidity }\end{array}$ & Duration & Reduction of water \\
\hline Post-salting & 3.0 & 82.0 & Weeks & $\%$ \\
Drying (I) & 8.0 & 77.0 & 7.4 & 12.0 \\
Drying (II) & 18.0 & 74.0 & 7.1 & 9.0 \\
Curing & 30.0 & 70.0 & 3.6 & 3.0 \\
\hline
\end{tabular}

\subsubsection{Psychrometric Analysis of Drying Chambers}

According to the model developed in section 5.3.5.1, a psychrometric analysis of each chamber was performed in order to obtain the different values for points 1 to 4 in Figure 25 and Figure 26. The procedure to obtain these values is detailed in the next paragraph.

Initial values of $T_{1}$ and $\mathrm{HR}_{1}$ are known since they are the set point values of temperature and humidity for the chamber. It is possible to obtain the value of $\omega_{1}$ from the psychrometric chart by identifying the intersection between the set point humidity curve and the dry-bulb temperature, as shown in Figure 26.

The mass flow of evaporated water from the surface of the ham $\dot{m}_{\text {evap }}$ can be calculated by means of equation 15 . Once this parameter has been obtained, it is possible to evaluate the amount of heat transferred from the ham to the air by equation 18. Then, an iterative process by means of equations $14,16,17$ and 18 and the psychrometric chart shown in Figure 26 is required to obtain the values of $\omega_{1}$ and $\dot{m}_{\text {air }}$. 
Table 32 includes the humidity ratio, dry-bulb and humid-bulb temperatures, specific enthalpy and relative humidity for each drying chamber at a pressure of $760 \mathrm{mmHg}$.

Table 32. Characteristic points in the psychrometric chart for the different chambers

\begin{tabular}{|c|c|c|c|c|c|c|}
\hline Chamber & Point & $\begin{array}{l}\text { Humidity } \\
\text { Ratio } \omega \\
\text { kg-w/kg-da }\end{array}$ & $\begin{array}{c}\text { Dry-bulb } \\
\text { temperature } \\
{ }^{\circ} \mathrm{C}\end{array}$ & $\begin{array}{c}\text { Humid-bulb } \\
\text { temperature } \\
{ }^{\circ} \mathrm{C}\end{array}$ & $\begin{array}{l}\text { Enthalpy } \\
\text { kJ/kg-da }\end{array}$ & $\begin{array}{c}\text { Relative } \\
\text { humidity } \\
\%\end{array}$ \\
\hline \multirow{4}{*}{ Post-salting } & 1 & 0.00376 & 3.00 & 1.66 & 12.29 & 80 \\
\hline & 2 & 0.00389 & 2.65 & 1.66 & 12.68 & 84 \\
\hline & 3 & 0.00389 & 0.51 & 0.51 & 10.62 & 100 \\
\hline & 4 & 0.00376 & 0.09 & 0.09 & 9.85 & 100 \\
\hline \multirow{4}{*}{ Drying (I) } & 1 & 0.00520 & 8.00 & 6.22 & 20.72 & 78 \\
\hline & 2 & 0.00542 & 7.45 & 6.22 & 21.3 & 84 \\
\hline & 3 & 0.00542 & 5.18 & 5.18 & 19.12 & 100 \\
\hline & 4 & 0.00520 & 4.56 & 4.56 & 17.94 & 100 \\
\hline \multirow{4}{*}{ Drying (II) } & 1 & 0.00970 & 18.00 & 15.28 & 41.69 & 75 \\
\hline & 2 & 0.01018 & 16.85 & 15.28 & 42.95 & 84 \\
\hline & 3 & 0.01018 & 14.40 & 14.40 & 40.68 & 100 \\
\hline & 4 & 0.00970 & 13.61 & 13.61 & 38.65 & 100 \\
\hline \multirow{4}{*}{ Curing } & 1 & 0.02019 & 30.00 & 26.23 & 79.58 & 75 \\
\hline & 2 & 0.02140 & 27.20 & 26.23 & 82.85 & 93 \\
\hline & 3 & 0.02140 & 26.08 & 26.08 & 82.13 & 100 \\
\hline & 4 & 0.02019 & 25.23 & 25.23 & 78.06 & 100 \\
\hline
\end{tabular}

\subsubsection{Evaluation of Reduced Speed}

The next step is to calculate the value of reduced speed to which fans need to be adjusted. The motor power rate is $1 \mathrm{HP}$ at $1500 \mathrm{rpm}$. Figure 33 shows different values for the power demanded by a fan for the studied chambers, which have been obtained by means of the model developed in chapter 5 , which modifies the fan speed. 


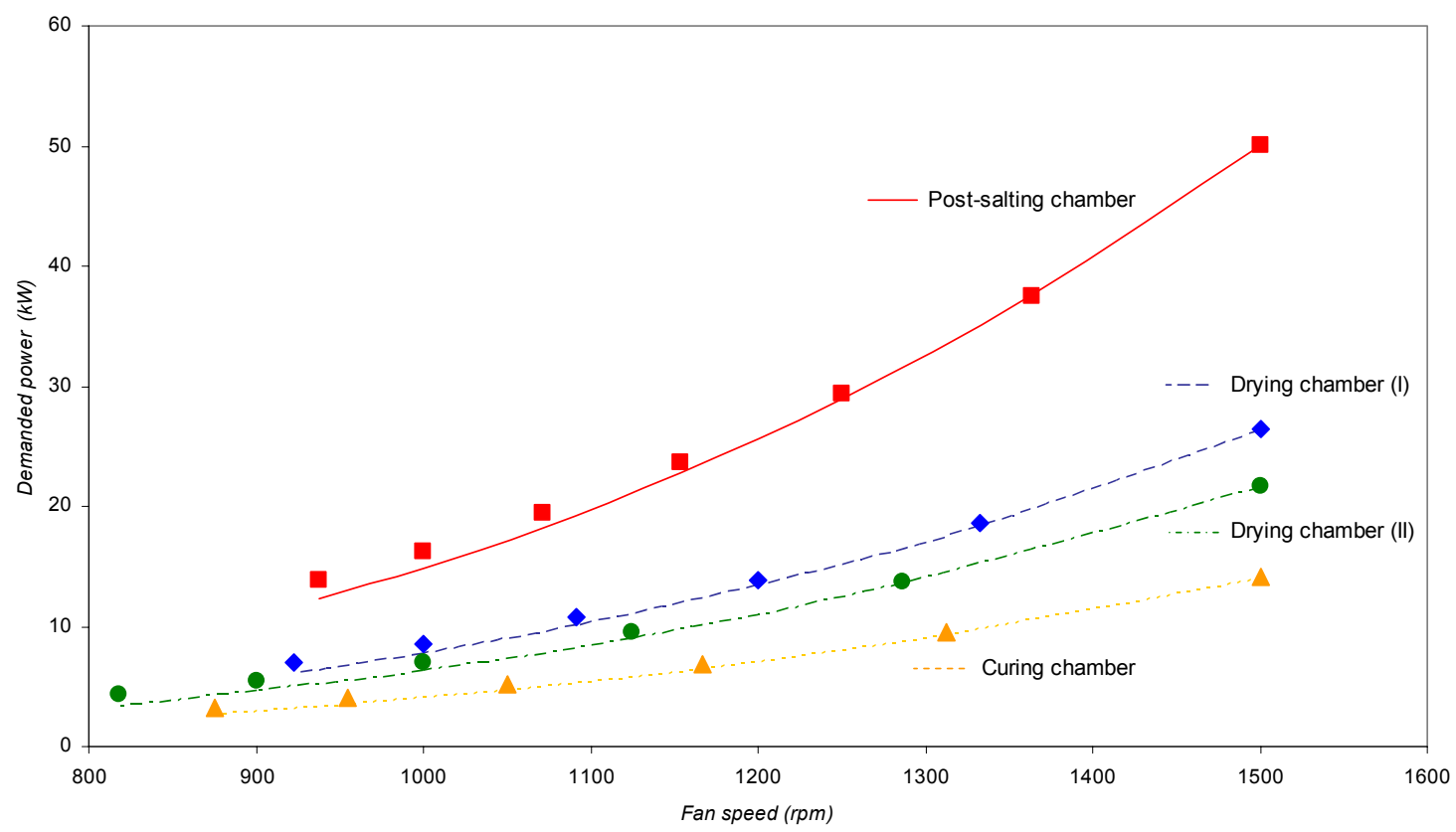

Figure 33. Relationship between the speed and the power required by fans These lines represent the variation of demanded power by fans according to their speed in each of the four drying chambers of the factory. $1 \mathrm{HP}$ motors at $1500 \mathrm{rpm}$ of nominal speed are used.

The cubic statement shown in equation 25 represents the interpolation with the lowest variability between these values. Table 33 includes factor $(A)$, which represents such relationships, as well as the correlation coefficient obtained in each case.

$$
P_{\text {fan }}=\left(A \cdot 10^{-9}\right) \cdot N^{3}
$$

Table 33. Factor and correlation coefficient of the power equation

\begin{tabular}{ccc}
\hline Chamber & $\mathbf{A}$ & $\mathbf{R}^{\mathbf{2}}$ \\
\hline Post-Salting & 0.148 & 0.9996 \\
Drying (I) & 7.813 & 0.9997 \\
Drying (II) & 4.166 & 0.9997 \\
Curing & 6.431 & 0.9998 \\
\hline
\end{tabular}


The initial period for which fans are switched on is equal to $50 \%$ of the postsalting stage and drying stage (I), 40\% for drying stage (II) and 35\% for the curing stage. However, the evaluation has been performed by considering that fans will be switched on for $80 \%$ of the duration of each drying stage. Table 34 below shows the variations that affect speed, power and duration of the different drying stages after implementing the fan speed reduction measure:

Table 34. Ratios of speed, power and time after applying the proposed actions

\begin{tabular}{cccc}
\hline Drying chamber / stage & $\begin{array}{c}\mathbf{N}^{\prime} \\
r p m\end{array}$ & N/N' & $\begin{array}{c}\Delta \text { power } \\
\%\end{array}$ \\
\hline Post-salting stage & 938.0 & 1.6 & -56 \\
Drying stage (I) & 750.0 & 2.0 & -68 \\
Drying stage (II) & 656.0 & 2.3 & -73 \\
Curing stage (I) & 563.0 & 2.7 & -78 \\
\hline
\end{tabular}

Reductions for six hours a day in several non-consecutive blocks of one hour are proposed, since longer reductions could result in the stratification of the chamber air and the unsatisfactory evolution of the drying process.

The application of these actions would allow the customer to save $43,114 \mathrm{kWh}$ every year, or $6 \%$ of total electricity consumption used in the ventilation process. As analyzed in the next chapter, such energy savings could mean up to a $13.8 \%$ reduction in the cost of the process, or $0.6 \%$ in the total cost of the factory.

While this relatively modest savings may not be enough incentive for customers to implement this action, a power demand reduction of $60 \%$ in the demand of the process (about $7 \%$ in the total demand of the factory) can be achieved, which could render significant savings if offered as a DR in operation markets. 


\subsection{Conclusions of the Chapter}

This chapter provides empirical evidence on the use of flexibility in a promising sector such as the meat industry. The effectiveness of proposed flexibility actions in a cured ham factory in Spain have been tested, and the results of real experiments are presented. Specifically, the two strategies proposed in Chapter 5 were implemented and studied for a period of two months in order to verify the profitability that they could have for both the customer and the system.

In order to validate the effectiveness of the first proposed strategy, based on the interruption of cooling systems, a campaign of interruptions was performed. One of the most significant conclusions is that such actions signify a notable reduction of the peak power demanded by the customer during certain periods of time, which could reach over $50 \%$ of the total power demanded by the factory without compromising the quality of the final product. This has been demonstrated by measuring the temperature and humidity inside drying rooms during the interruptions. Variations in these parameters are within the range of usual deviations registered by meters located in different points of the chamber, producing an insignificant impact on the product.

Regarding the second strategy, savings of about the $8 \%$ in the total power demanded by the factory can be obtained, since the power demanded by fans is reduced proportionally to the cube of the rotation speed, as is numerically demonstrated. Power reduced is less significant than for the first strategy since the power demanded by ventilation is lower. However, reductions could be maintained for longer because the amount of water extracted from a drying room remains unchanged if fans operate at reduced speed for longer periods. Therefore, combinations of both strategies could be applied for reductions with diverse durations or magnitudes, so that very flexible packages of energy can be built and offered to the system. 
As the technical impact of the implementation of flexibility on customers has been analyzed, the economic impact of such strategies, including both customer and system evaluations, is discussed in the next chapter. 


\section{CHAPTER 7 :}

\section{ECONOMIC AND ENVIRONMENTAL EVALUATION OF FLEXIBILITY}

\subsection{Chapter Overview}

The objective of this chapter is to complete the application of the developed methodology for a flexibility assessment. In the previous chapter, the methodology was applied to a customer from the meat industry in order to validate the technical potential of the food-processing sector. This chapter complements that evaluation with an economic analysis as described in Chapters 3 and 4. Additionally, the environmental impact is evaluated by estimating the amount of $\mathrm{CO}_{2}$ emissions that are avoided due to reductions in energy consumption.

The particular market conditions in the Spanish context have been considered, as this information is necessary for the application and evaluation of flexibility. Thus, real prices of operation markets in Spain have been used to evaluate the potential profitability, even if customers are not actually allowed to participate in such markets at the moment.

The economic evaluation requires a cost-benefit analysis, as presented in the methodology. The procedure followed will evaluate the maximum daily benefit obtained by the customer when offering all its flexibility in operation markets, so that it can make a decision based on the expected benefits. In order to determine the value of this benefit, different aspects will be evaluated, including the amount of money saved during the flexibility actions due to the energy not consumed or shifted to cheaper periods, as well as the costs that the customer incurs when a flexibility action is performed. Finally, the 
obtained results for a typical customer will be extrapolated to the whole segment in Spain.

\subsection{Electricity Market Overview in Spain}

Spain belongs to the Iberian Electricity Market (MIBEL), which is common for Spain and Portugal. Created in 2001, MIBEL is composed of different organized and non-organized markets where electricity and related financial instruments are traded. About 29 million customers, consuming 300 TWh annually, participate in this market ${ }^{42}$.

\subsubsection{Market Organization}

MIBEL can be divided into organized and non-organized markets. Organized markets include:

- The forward market, where continuous operation or auctions are used and which allows physical or financial settlements. This market is managed by OMIP (the Portuguese pole), which controls, oversees and compensates the forward market.

- Spot market, managed by OMEL (the Spanish pole) where two time horizons are considered:

○ Daily market, if energy packages for the day following the contract are traded

○ Intra-daily market, if traded packages of energy are delivered within less than 24 hours

- Operation markets. These are managed individually in Portugal and Spain by the respective TSOs.

42 This information has been obtained from the Comisión Nacional de la Energía (CNE), http://www.cne.es, accessed in December 2010. 
Non-organized markets (over-the-counter trading) are based on bilateral contracts between any of the participants in the market.

Most energy is traded in organized markets, and the Spot market is preferred by Iberian customers, as shown in Figure 34.

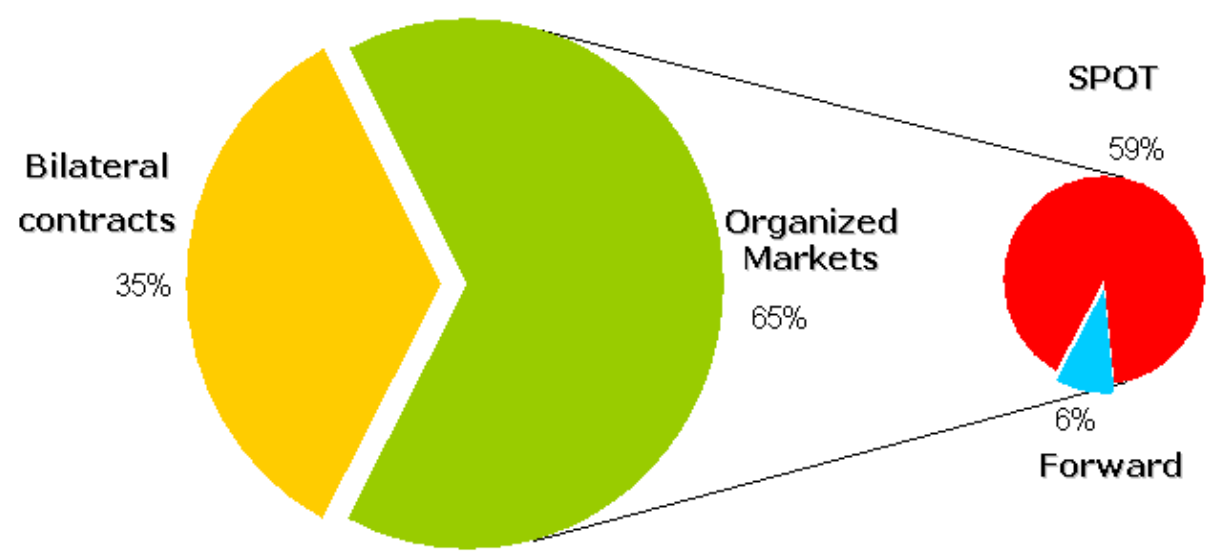

Figure 34. Participation of customers in the MIBEL electricity market

Two-thirds of Iberian customers trade electricity in organized markets, while bilateral contracts are preferred by only a third of participants. Among the different options available in organized markets, forward markets are used by just $6 \%$ of customers, whereas $59 \%$ of customers in Spain and Portugal use the Spot market.

\subsubsection{How Do Customers Pay for Electricity in Spain?}

Customers can purchase their electricity supply by means of two basic options:

- All customers can contract their electricity supply in the deregulated market by participating in organized or non-organized markets.

- Additionally, small customers who contract less than $10 \mathrm{~kW}$ can take advantage of a regulated tariff.

Residential customers can purchase electricity on the deregulated market, but they usually sign a regulated contract with prices set by the government. On the other hand, commercial and industrial customers participate in deregulated markets. Only a 
few customers participate directly, so an intermediary, the "trader," buys electricity in the wholesale market and sells it as a retailer to customers at a freely agreed price.

\subsubsection{Components of the Electricity Bill}

The electricity bill of customers participating in the deregulated market has two components:

- A variable cost that depends on the customer's electricity consumption, which is invoiced at the price negotiated with the trader.

- A fee (access tariff) that the customer pays to the distributor for use of the grid.

The access tariff is composed of four terms: a variable term that depends on energy consumption (energy term); a fixed term related to the contracted power (power term); a variable term which applies penalties when the customer's power demand exceeds the maximum power permitted in the contract (active power excess term); and, finally, a term which invoices the amount of reactive energy consumed by the customer when the average power factor during the month is under 0.95 (reactive term).

Depending on the access tariff contracted by the customer, different periods could be applied, ranging from a single period (flat contract) for customers with less than $10 \mathrm{~kW}$ of contracted power, to six periods for customers contracting more than $450 \mathrm{~kW}$.

\subsubsection{Hourly Periods of the Contract}

The possibilities that contracts offer to customers in terms of pricing regimes used throughout a year are very broad, with up to six different periods in the most complex scheme. Depending on the voltage at which the electricity is supplied to the customer and the maximum amount of power that will be contracted, customers have the following possibilities: 
- A single period (flat contract), for customers with low voltage demand whose contracted power is lower or equal to $15 \mathrm{~kW}$.

- Two periods (day and night tariff), for customers in the same range of power and voltage who opt to contract this complement. This alternative charges higher prices during peak periods and lower prices during valley periods. The peak period takes place from noon to $10: 00 \mathrm{pm}$ in winter and from 1:00 pm to $11: 00 \mathrm{pm}$ in summer.

- Three periods (on-peak, shoulder and valley). All customers can opt for this regime, for both low and high voltage. Prices are higher during peak and lower during valley, while the price in the shoulder period is the mean. Periods are defined differently in summer and winter, and they depend on customer voltage level (see Table 35). Moreover, working days and non-working days are defined with different periods for high voltage customers.

Table 35. Definition of periods for peak-shoulder-valley contracts in Spain

\begin{tabular}{|c|c|c|c|c|c|}
\hline & & & \\
\hline & & & On-peak & Shoulder & Valley \\
\hline \multirow{2}{*}{$\begin{array}{l}\text { Low } \\
\text { Voltage }\end{array}$} & \multirow{2}{*}{$\begin{array}{l}\text { Working } \\
\text { days }\end{array}$} & winter & $6 \mathrm{pm}$ to $10 \mathrm{pm}$ & $\begin{array}{l}8 \mathrm{am} \text { to } 6 \mathrm{pm} \\
10 \mathrm{pm} \text { to midnight }\end{array}$ & midnight to 8 am \\
\hline & & summer & $11 \mathrm{am}$ to $3 \mathrm{pm}$ & $\begin{array}{l}8 \mathrm{am} \text { to } 11 \mathrm{am} \\
3 \mathrm{pm} \text { to midnight }\end{array}$ & midnight to $8 \mathrm{am}$ \\
\hline \multirow{4}{*}{$\begin{array}{l}\text { High } \\
\text { Voltage }\end{array}$} & \multirow{2}{*}{$\begin{array}{l}\text { Working } \\
\text { days }\end{array}$} & winter & $5 \mathrm{pm}$ to $11 \mathrm{pm}$ & $\begin{array}{l}8 \mathrm{am} \text { to } 5 \mathrm{pm} \\
11 \mathrm{pm} \text { to midnight }\end{array}$ & midnight to 8 am \\
\hline & & summer & $10 \mathrm{am}$ to $4 \mathrm{pm}$ & $\begin{array}{l}8 \mathrm{am} \text { to } 10 \mathrm{am} \\
4 \mathrm{pm} \text { to midnight }\end{array}$ & midnight to 8 am \\
\hline & \multirow{2}{*}{$\begin{array}{c}\text { Non- } \\
\text { working } \\
\text { days }\end{array}$} & winter & - & $6 \mathrm{pm}$ to midnight & midnight to $6 \mathrm{pm}$ \\
\hline & & summer & - & $6 \mathrm{pm}$ to midnight & midnight to $6 \mathrm{pm}$ \\
\hline
\end{tabular}

Source: Spanish Act ITC 2794/2007 and ITC 3801/2008 
Six periods (seasonality). High voltage customers can contract this possibility if power contracted in the valley period is at least $451 \mathrm{~kW}$. The value of contracted power in the rest of the periods could be different, but the power contracted in the previous period must be lower or equal to the value in the subsequent period. Prices are different for each period, where the most expensive price is assigned to period $\mathrm{P} 1$, and the cheapest to period P6; the rest of periods have intermediate values. Three periods are defined per day (on-peak, shoulder and valley), and they are different in each season (high, medium and low season). Table 36 specifies the different periods throughout the year, which are assigned as follows:

- P1 are on-peak hours on working days in high season (January, February, the second half of June, July and December)

- P2 are shoulder hours on working days in high season

○ P3 are on-peak hours on working days in medium season (March, the first half of June, September and November).

○ P4 are shoulder hours on working days in medium season

- P5 are shoulder hours on working days in low season (April, May and October)

○ P6 are valley hours during the whole year (every day from midnight to 8 am, 24 hours a day on Saturdays, Sundays and public holidays, and the whole month of August, since most people are off work).

The assignment of periods is different in winter and summer and can even vary between months in the same season. This means that energy and power prices for the same period have the same value although the particular hours defined for each period are different. For example, September and November are considered medium season 
months, yet the peak period P3 is located in the morning in September but in the afternoon for November.

Table 36. Definition of periods in seasonal contracts in Spain

\begin{tabular}{|c|c|c|c|c|c|c|c|c|}
\hline & & & $\begin{array}{c}\text { January, } \\
\text { February } \\
\text { and } \\
\text { December }\end{array}$ & $\begin{array}{l}\text { 2nd half of } \\
\text { June and } \\
\text { July }\end{array}$ & $\begin{array}{l}\text { March and } \\
\text { November }\end{array}$ & $\begin{array}{l}\text { 1st half of } \\
\text { June and } \\
\text { September }\end{array}$ & $\begin{array}{c}\text { April, May } \\
\text { and } \\
\text { October }\end{array}$ & August \\
\hline \multirow{8}{*}{ 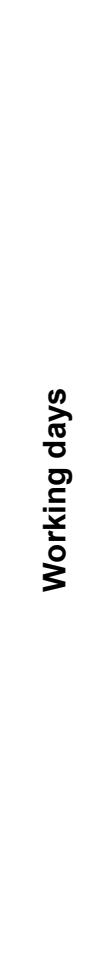 } & \multirow{3}{*}{ 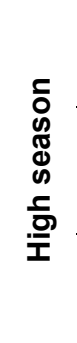 } & $\begin{array}{l}\text { On-peak } \\
\text { (P1) }\end{array}$ & $\begin{array}{l}10 a m-1 p m \\
6 p m-9 p m\end{array}$ & 11am-7pm & - & - & - & - \\
\hline & & $\begin{array}{l}\text { Shoulder } \\
\text { (P2) }\end{array}$ & $\begin{array}{c}\text { 8am-10am } \\
\text { 1pm-6pm } \\
9 p m-12 a m\end{array}$ & $\begin{array}{l}\text { 8am-11am } \\
7 p m-12 a m\end{array}$ & - & - & - & - \\
\hline & & $\begin{array}{c}\text { Valley } \\
\text { (P6) }\end{array}$ & 12am-8am & 12am-8am & - & - & - & - \\
\hline & \multirow{3}{*}{ 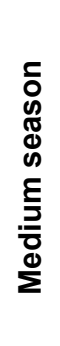 } & $\begin{array}{l}\text { On-peak } \\
\text { (P3) }\end{array}$ & - & - & 4pm-10pm & $9 a m-3 p m$ & - & - \\
\hline & & $\begin{array}{l}\text { Shoulder } \\
\text { (P4) }\end{array}$ & - & - & $\begin{array}{c}8 a m-4 p m \\
10 p m-12 a m\end{array}$ & $\begin{array}{c}\text { 8am-9am } \\
\text { 3pm-12am }\end{array}$ & - & - \\
\hline & & $\begin{array}{l}\text { Valley } \\
\text { (P6) }\end{array}$ & - & - & 12am-8am & 12am-8am & - & - \\
\hline & \multirow{2}{*}{ 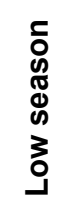 } & $\begin{array}{l}\text { Shoulder } \\
\text { (P5) }\end{array}$ & - & - & - & - & 8am-12am & - \\
\hline & & $\begin{array}{l}\text { Valley } \\
\text { (P6) }\end{array}$ & - & - & - & - & 12am-8am & - \\
\hline \multicolumn{2}{|c|}{$\begin{array}{c}\text { Non-working } \\
\text { days }\end{array}$} & $\begin{array}{c}\text { Valley } \\
\text { (P6) }\end{array}$ & $\begin{array}{l}24 \text { hours } \\
\text { a day }\end{array}$ & $\begin{array}{l}24 \text { hours } \\
\text { a day }\end{array}$ & $\begin{array}{l}24 \text { hours } \\
\text { a day }\end{array}$ & $\begin{array}{l}24 \text { hours } \\
\text { a day }\end{array}$ & $\begin{array}{l}24 \text { hours } \\
\text { a day }\end{array}$ & $\begin{array}{c}24 \text { hours } \\
\text { a day }\end{array}$ \\
\hline
\end{tabular}

Source: Spanish Act ITC 2794/2007

\subsubsection{Operation Markets in Spain}

The Spanish TSO, Red Eléctrica de España, manages the technical and economic aspects of operation markets in Spain, which include: 
- Solution of technical restrictions. This is aimed at solving any incidents in the generation-transmission system that could affect the safety, quality or reliability or the power system.

- Ancillary services. These include such services as primary, secondary and tertiary regulation or voltage control, and are focused on guaranteeing the proper power supply to customers in reliable and safe conditions.

- Balancing markets. Their objective is to reconcile the deviation between demand and generation that could appear after the closing of the pool and until the beginning of the next pool market session.

As stated in Chapter 4, Spanish customers are not allowed to participate in operation markets, unlike customers in other countries. Only very large customers (with a reducible power larger than $5 \mathrm{MW}$ ) can participate in the interruptibility program offered by REE (see section 2.6.2.9), although the strict requirements asked of participants mean that only about 200 customers in Spain provide the system with this service. However, some recent changes, such as the creation of the DSM department in REE or the detailed publication of different operation market results online ${ }^{43}$ suggest advances in this field, so a modification in the market rules to increase DR participation in the operation of the system is expected in the near term [111].

The next sections evaluate the economic impact of customer participation in operation markets such as balancing markets or secondary regulation to identify the potential benefits for customers and the savings for the system.

43 Detailed results of operation markets in Spain are published in real time at URL: http://www.esios.ree.es 


\subsection{Economic Evaluation of Flexibility in the Meat Industry}

According to the methodology detailed in Chapters 3 and 4, this section assesses the economic impact of customer flexibility in the meat industry. Real data from the Spanish factory whose flexibility was validated in Chapter 6 will be used, and the obtained results will be extrapolated to the whole segment.

\subsubsection{Cost-Benefit Analysis for the Customer}

A cost-benefit analysis is required to assess the net benefit necessary to persuade the customer to reduce its load. This begins by examining the costs that the customer incurs when managing its load. Using this data, the participation of the customer in operation markets for a whole year can be simulated to assess the profit it earns every hour.

The method used for this economic evaluation has followed the following steps [112]:

1. Evaluation of customer costs due to flexibility actions, considering direct and indirect costs as detailed in section 3.6.2.1.

2. Assessment of the savings obtained by the customer due to not consuming energy during the flexibility action, taking into account the extra cost during the recovery period. This evaluation was performed based on the different prices in the electricity contract for different periods throughout the year. The customer has a seasonal contract, so a sixperiod definition as specified in Table 36 was used. Actions involving reductions of two hours, which implement the first and second strategies, were examined, and a total reduction of $711 \mathrm{~kW}$ for each hour was evaluated. Likewise, a recovery period of $114 \mathrm{~kW}$ for the hour following the reduction was also taken into account. 
3. Definition of the benefit strategy to participate or not in operation markets. Customers must quantify the benefit they require to be willing to modify their loads, which will depend on their own market strategy. For this simulation, we have assumed that the customer will manage its loads when the payments obtained from the system are $50 \%$ or more of the cost of the offered amount of power, according to the weighted average price in its electricity contract, and after discounting the extra costs that the customer incurs.

4. Evaluation of the hours in which the customer may actually participate in the considered operation market. This would happen when the system operator offers a payment equal or higher than the expected benefit (as explained above). Moreover, the load reduction could only take place for a maximum of two consecutive hours, twice a day.

5. Evaluation of the avoided costs for the system, determined to be the difference between the payments to the customer when managing its load and the cost of the considered operation market when only generation resources are considered.

\subsubsection{Flexibility Costs Evaluation}

Costs that the customer incurs when a flexibility action is performed are evaluated in Table 37, including an estimation of direct and indirect costs (see section 3.6.2.1) 
Table 37. Costs of flexibility for a customer in the meat industry

\begin{tabular}{|c|c|c|c|c|}
\hline \multirow{6}{*}{$\begin{array}{l}\text { DIRECT } \\
\text { COSTS }\end{array}$} & & Control & Monitoring & \\
\hline & Capital cost & 15000.00 & 5000.00 & $€ /$ device \\
\hline & Expected lifetime & 15.00 & 15.00 & years \\
\hline & Working hours & 240.00 & 240.00 & hours/year \\
\hline & Amortization & 4.17 & 1.39 & $€ / \mathrm{h}$ \\
\hline & TOTAL DC & 5.56 & & $€ / h$ \\
\hline \multirow{7}{*}{$\begin{array}{c}\text { INDIRECT } \\
\text { COSTS }\end{array}$} & Annual personnel & & 30000.00 & $€ /$ employee \\
\hline & Hours/week & & 40.00 & hours/week \\
\hline & Weeks/year & & 50.00 & weeks/year \\
\hline & Cost of working ho & & 15.00 & $€ /$ hour \\
\hline & Time used for flexi & ty action & 20.00 & minutes \\
\hline & Labor cost & & 5.00 & $€ / h$ \\
\hline & TOTAL IC & 5.00 & & $€ / \mathrm{h}$ \\
\hline \multicolumn{2}{|c|}{ TOTAL FLEX. COST } & 10.56 & & $€ / h$ \\
\hline
\end{tabular}

\subsubsection{Participation in Operation Markets Simulation}

A net reduction of $711 \mathrm{~kW}$ could potentially be offered by the customer in operation markets as a result of combining the first and second strategies at the same time. Conversely, a recovery period of one hour is also needed, during which an additional $114 \mathrm{~kW}$ are demanded.

Customer participation in two different operation markets has been evaluated, so prices of balancing markets and the secondary regulation market have been considered for the mobile year between November 25, 2009 and November 25, 2010. Prices were obtained from the official REE website, where this information is published and updated daily.

\subsection{Balancing Markets Simulation}

Prices of balancing markets varied in the considered period from $5 €$ to $210 € / M W h$, as shown in Figure 35. 


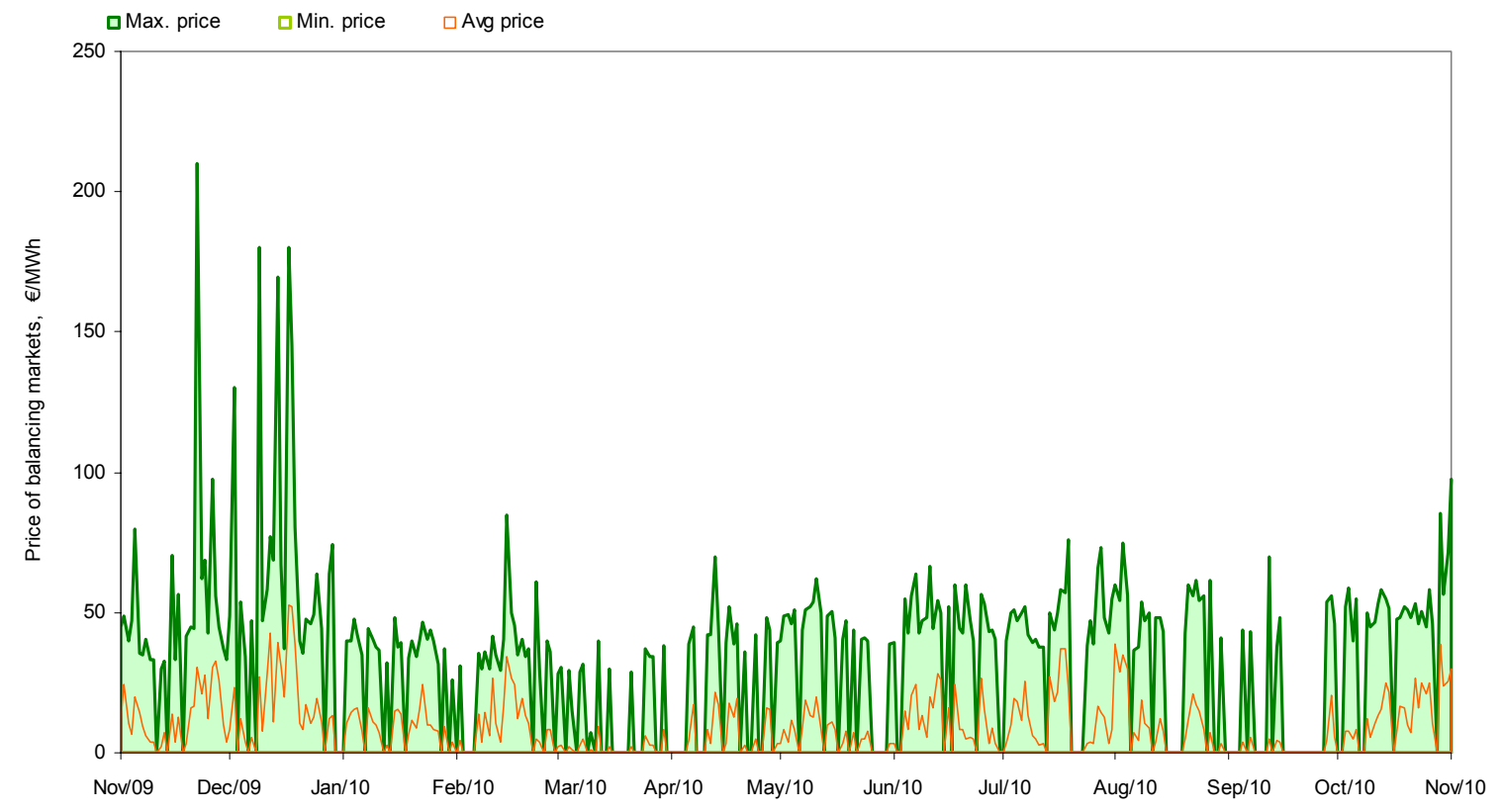

Figure 35. Prices in the Spanish balancing market from November '09 to November ' 10 Hourly prices in the Spanish balancing market are shown in this graphic. The maximum price was registered in November 2009, with a value equal to $210 € / \mathrm{MWh}$. The minimum price for this operation market was $5 € / \mathrm{MWh}$, after discounting the 0 values that belong to hours in which this market was not activated by REE.

According to the method proposed in section 7.3.1, a total of 670 hours, whose daily assignment is shown in Figure 36, were considered acceptable in the simulation, since the customer could obtain at least the minimum required benefit.

If the customer had participated in this market for all the considered hours, it would have obtained a benefit up to $45,271 €$, or $6.2 \%$ of the total cost of electricity. $32,588 €$ comes from energy not consumed by the customer (savings), including the different costs that the customer incurs, and $12,683 €$ are direct payments from the TSO. 


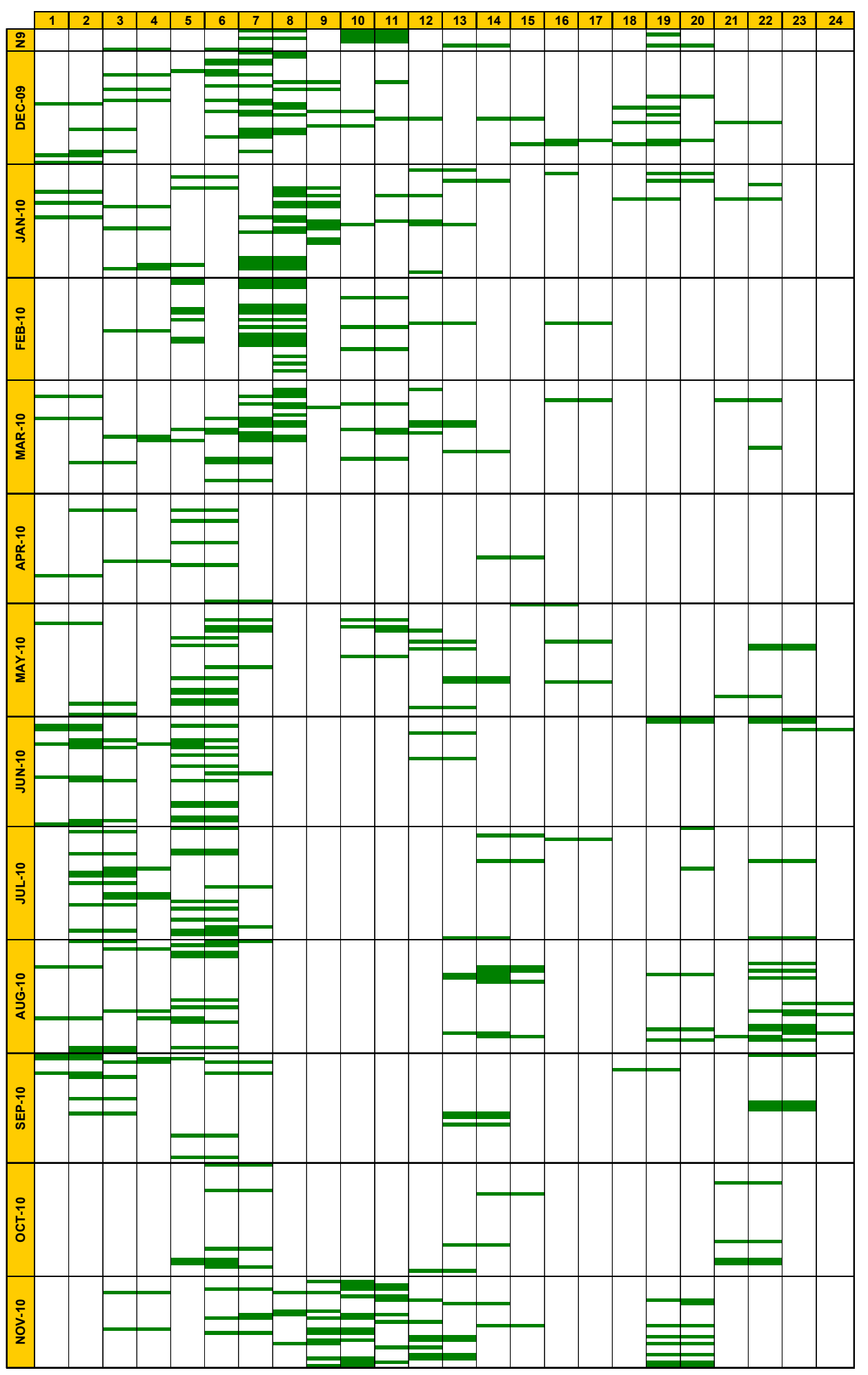

Figure 36. Participation hours in balancing markets

The most profitable hours for customer participation in balancing markets are represented in this figure, showing a total application of 670 hours. 
The actual cost that this reduction of power had for the system by using generation resources was $21,639 €$. Consequently, the system would have saved $8,956 €$ if $\mathrm{DR}$ from this customer had been used instead of only generation resources. Figure 37 shows the monthly result of this customer's participation in the balancing market. The most profitable month for customer participation, from both the customer and system perspective, was November, when the customer would have earned $7,365 €$ while the system would have saved $1,243 €$.

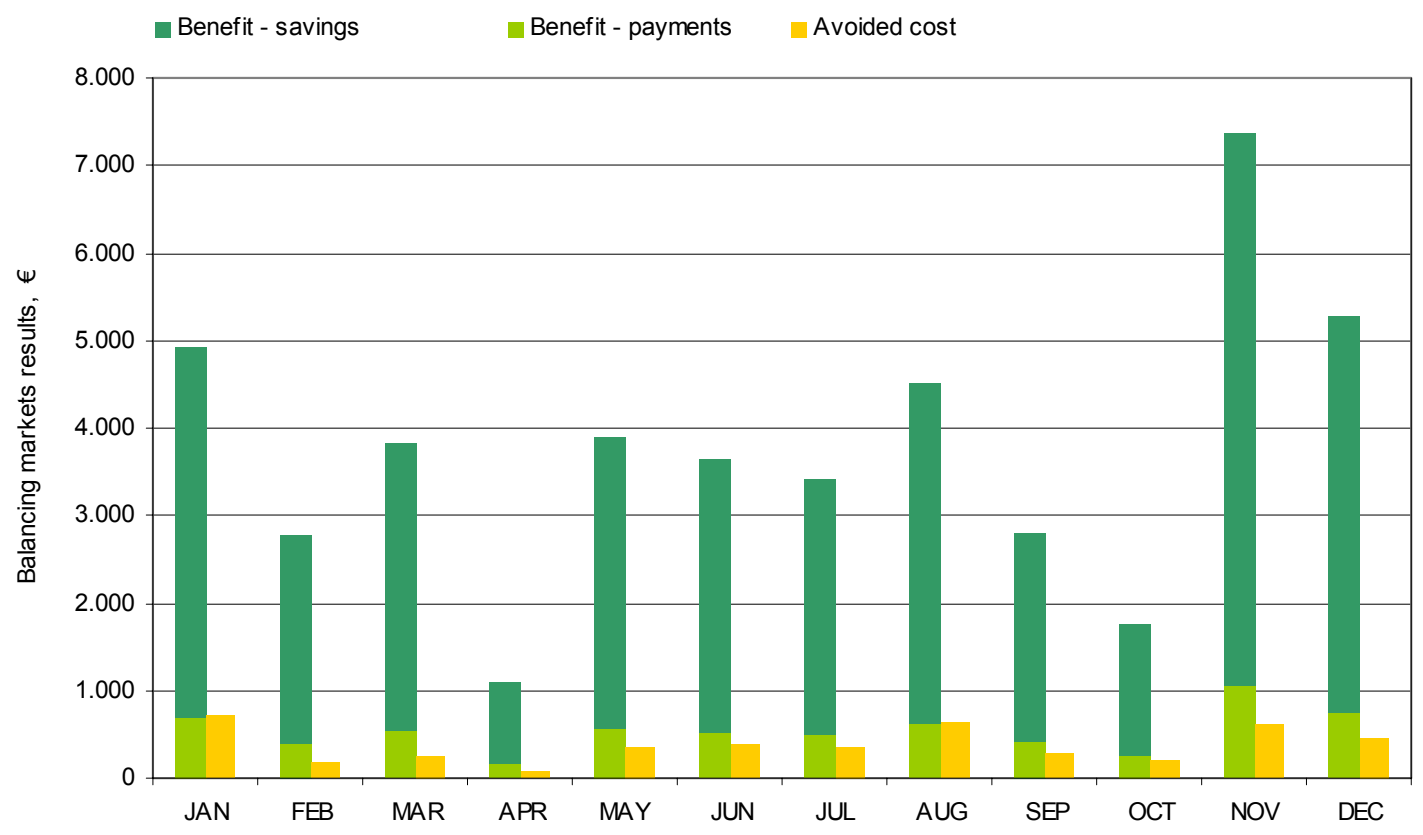

Figure 37. Monthly results of customer participation in the Spanish balancing market This figure shows the benefit that the customer would have obtained if it had participated in balancing markets from November 2009 to November 2010, as well as the avoided cost for the System in the same period, if the TSO had used DR instead of generation resources. Likewise, the number of hours for which the customer would have obtained a benefit is shown. November would have been the most profitable month for both the customer and the System. 


\subsection{Secondary Regulation Simulation}

The participation of the customer in the Spanish secondary regulation market was also evaluated, similarly to the analysis performed on the balancing market. The secondary regulation market has two components, since customers are paid for availability (reserves) as well as for actual delivery of the power. Figure 38 and Figure 39 show the prices for availability and delivered energy in the Spanish secondary regulation market, from November 25, 2009 to November 25, 2010.

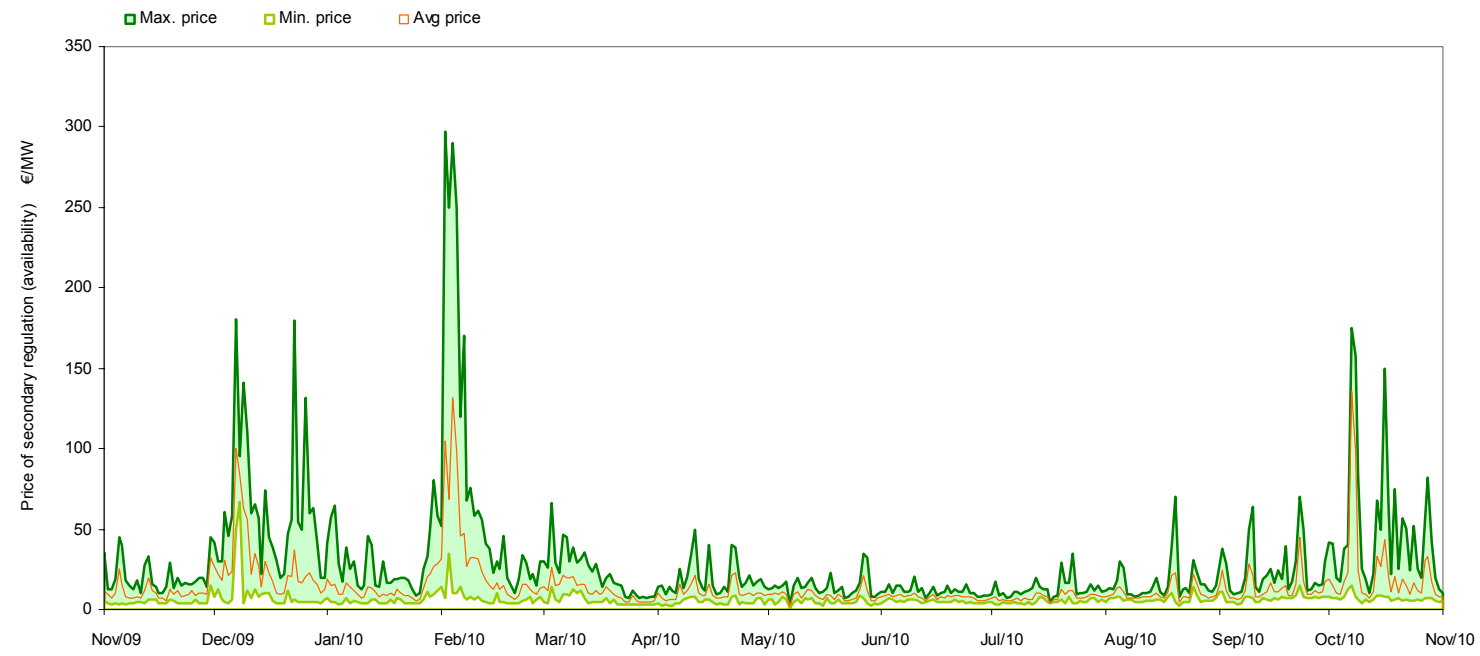

Figure 38. Prices in the Spanish secondary regulation market (availability) This graphic shows the hourly prices in the secondary regulation market (availability) in Spain. These prices are paid to participants when they are willing to deliver an amount of power (if required) for secondary regulation, even if the delivery is not actually requested by the TSO. The maximum price, achieved in February 2010, was 297€/MW.

The customer would obtain a minimum required benefit for a total of 450 hours, whose daily assignment is shown in Figure 40.

Participating in the secondary reserve for all the hours under consideration, the customer would have obtained a benefit of $6,594 €$, equivalent to $0.9 \%$ of the total cost of electricity. At the same time, the system would have saved $9,263 €$ by using the customer's capacity instead of conventional generation. 


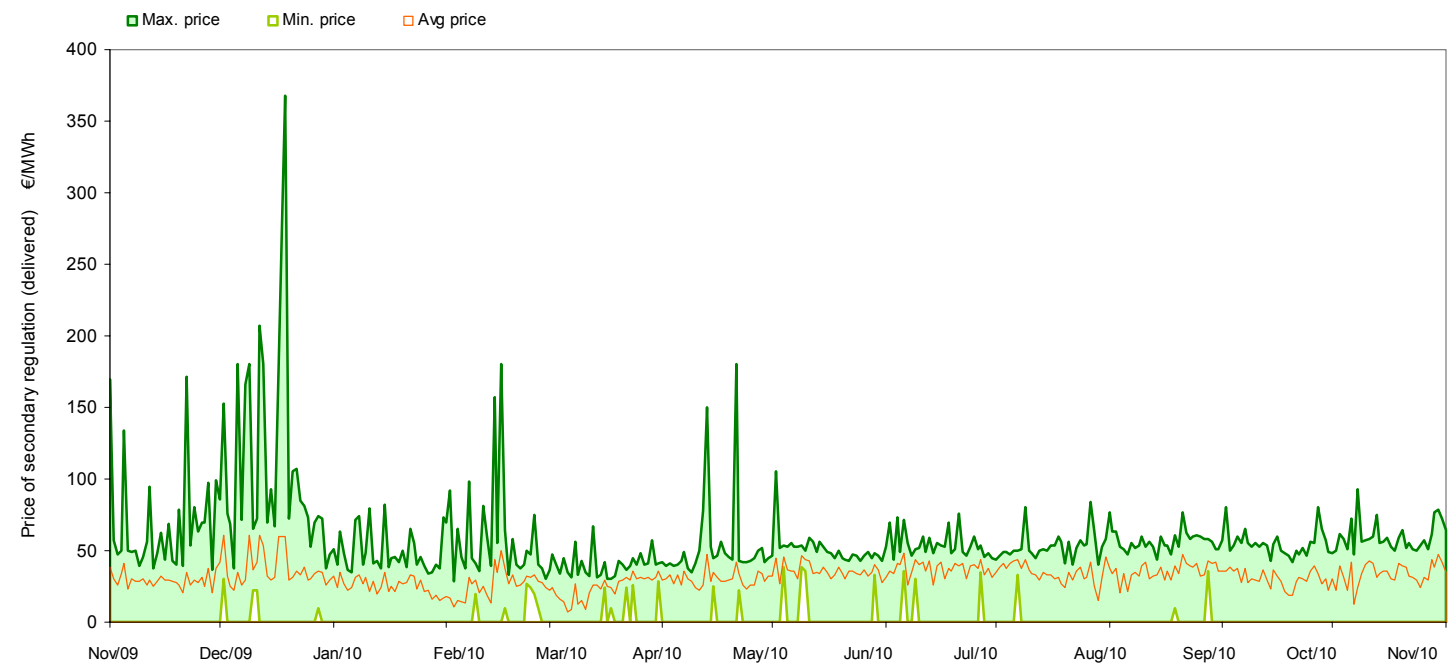

Figure 39. Prices in the Spanish secondary regulation market (delivery) Hourly prices of the Spanish secondary regulation market (delivery) are shown in this graphic. The maximum price, achieved in December 2009, was 368€/MWh.

In addition to the benefit obtained by the customer for its availability, an additional payment of $7,781 €$ would have been obtained if the power was delivered during the pledged hours. This can be added to the savings achieved by avoiding consumption, which reach $17,408 €$ after discounting costs. Therefore, a total benefit of $31,783 €$ could be obtained by the customer, which is $4.4 \%$ of the total cost of electricity.

Figure 41 shows the monthly results of this customer's participation in the secondary regulation (availability + delivery) market. The most profitable month for customer participation, for both the customer and the system, was January, when the customer would have earned $7,256 €$, and the system would have saved $2005 €$. 


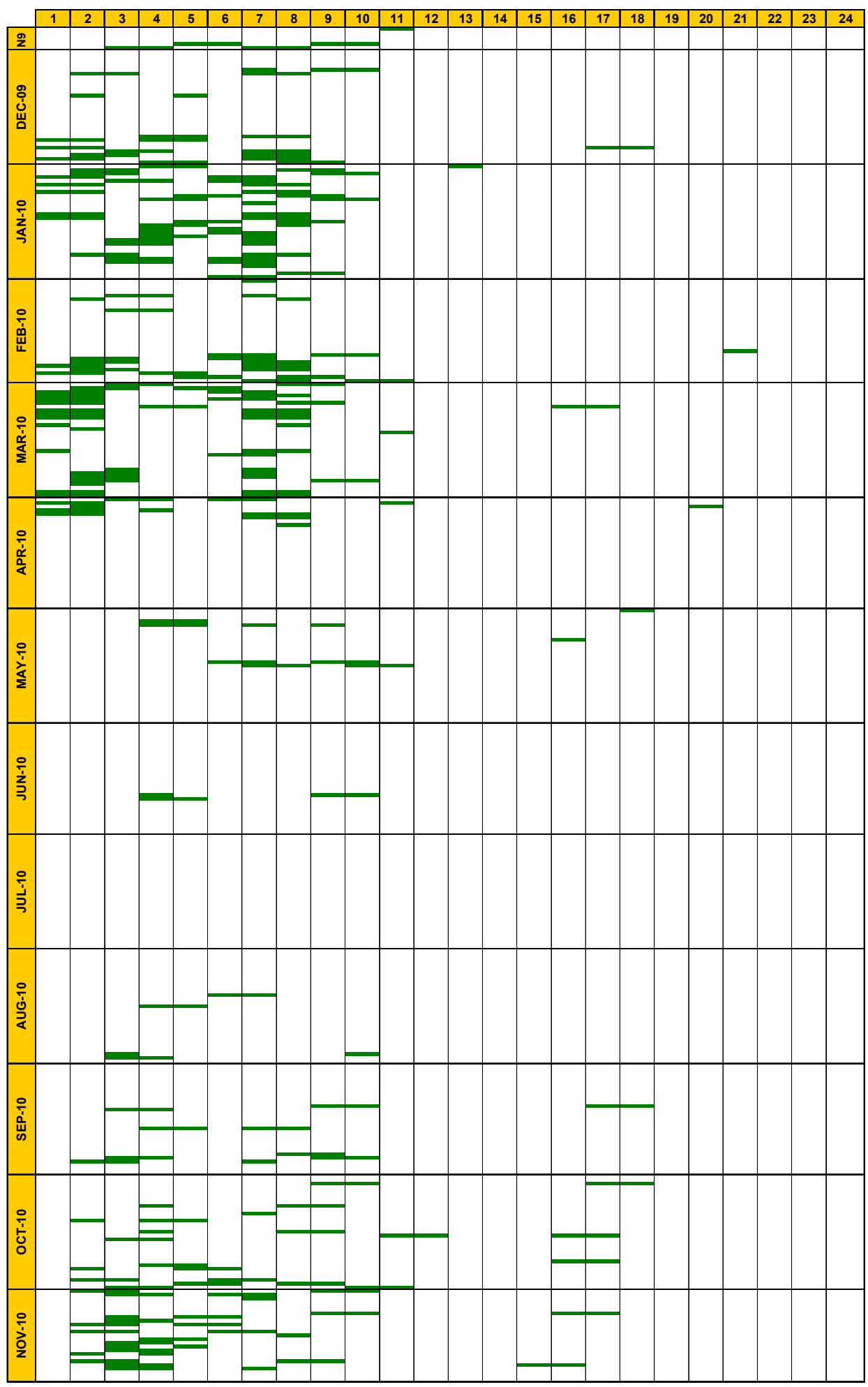

Figure 40. Participation hours in secondary regulation

The most profitable hours (a total of 393) during which the customer could participate in secondary regulation are represented in this figure. 


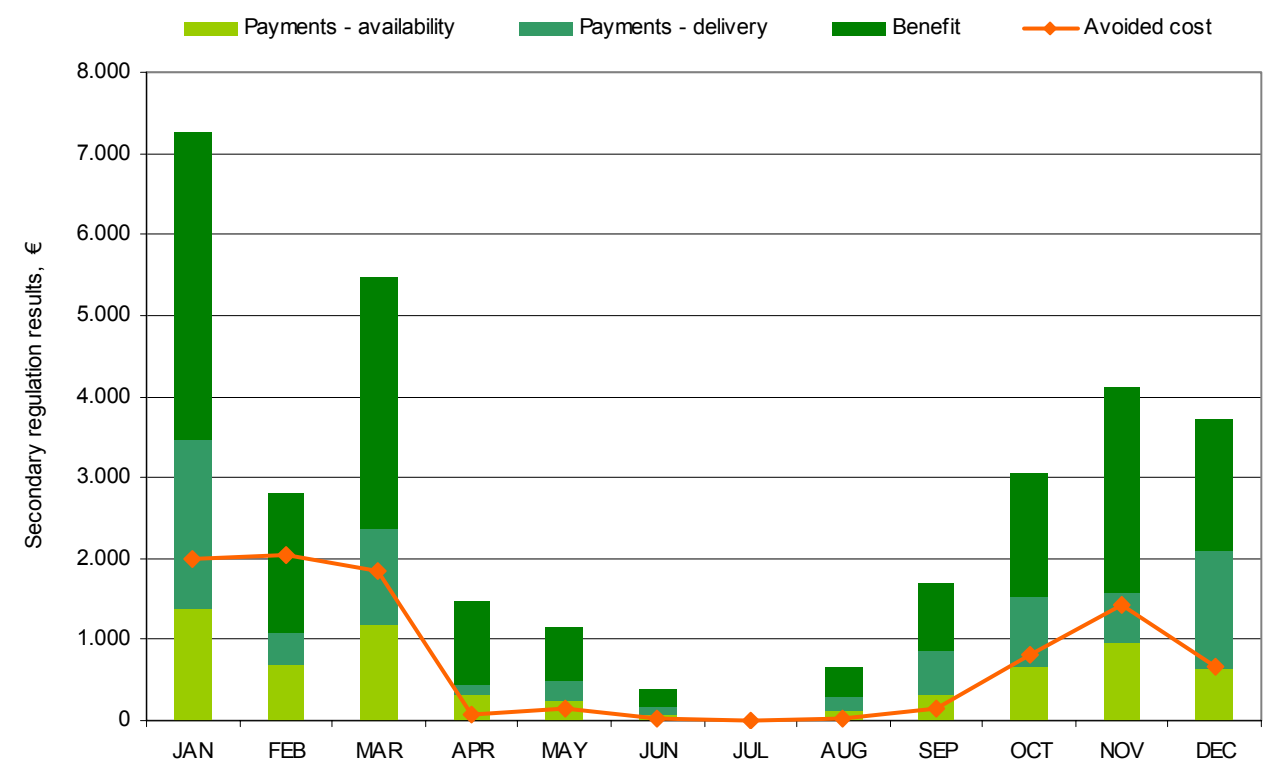

Figure 41. Monthly results of customer participation in the secondary regulation market This figure shows the benefit that the customer would have obtained if it had participated in secondary regulation (availability and delivery), as well as the avoided cost for the System in the same period, if the TSO had used DR instead of generation resources. January would have been the most profitable month for both the customer and the System.

\subsubsection{Extrapolation of Results to the Whole Segment}

The potential for customers in the whole segment of the meat products industry has been estimated by using tools developed in the project carried out by the International Energy Agency (IEA), task XIII “Demand Response Resources" [27], of the Implementing Agreement on Demand Side Management. These tools estimate the available market potential for demand response in electricity markets. For the calculation, benchmark information gathered from experiences with consumers in Europe and America is used. Table 38 shows the inputs considered in order to estimate the potential of demand response in the meat industry in Spain, which has been estimated at $441 \mathrm{MW}$. 
Table 38. Inputs for the IEA task XIII tool - segment of meat products

\begin{tabular}{lr}
\hline Number of meat products factories in Spain & 4505 \\
\hline Peak power in Spain, MW & 43,378 \\
\hline Peak power for a typical factory, MW & 0.964 \\
\hline Avg. reducible power for a typical factory, MW & 0.710 \\
\hline Estimated potential in meat industry (Spain), MW & 441 \\
\hline
\end{tabular}

Source: Asociación de Industrias
de la Carne de España
Source: REE
Source: Dissertation tests
Source: Dissertation tests
Task XIII tool

According to these results, it is possible to conclude that the meat products segment has a high potential to provide demand response resources to the system, with very profitable results. During the considered period (from November 25, 2009 to November 25, 2010), about 2011 GWh were managed in balancing markets in Spain, with a cost of $85,534 €^{44}$. Taking into account the potential estimated above, $14.7 \%$ of this energy could have been reduced by customers from the meat producing segment. This would have avoided system costs of approximately $5,557 €$, or $6.5 \%$ of the total cost of balancing markets for the system in this period.

Similarly, the cost of the secondary reserve up for the considered period was $92,836 €^{45}$. The estimated avoided cost for the system, considering the potential of the whole segment, is $5,731 €$. Thus, the system could save about $6.2 \%$ of the total cost of secondary regulation if DR from this segment were used.

\subsection{Environmental Impact of DR}

As stated in section 3.6.2.2, the assessment of avoided emissions into the atmosphere could be performed by considering the weighted coefficients which assess the amount of $\mathrm{CO}_{2}$ per MWh emitted in each time period.

Below, the avoided emissions into the atmosphere will be assessed for the customer analyzed in this chapter. The procedure that will be used is the following:

\footnotetext{
${ }^{44}$ This information has been obtained from the Spanish TSO. http://www.esios.ree.es

${ }^{45}$ The information has been also obtained from the Spanish TSO. http://www.esios.ree.es
} 
- First of all, the total emissions by the customer when no reductions are produced will be evaluated by assessing the consumption of energy in each one of the six periods defined in the contract. For that purpose, the emission coefficients stated in Table 39 will be considered, and the emission of each period will be calculated by multiplying the consumption of each period by the assigned factor.

- Secondly, emissions will be calculated after implementing the flexibility strategies dealt with in the chapter, including the extra consumption produced during the recovery period of the first strategy.

- Finally, the avoided emissions into the atmosphere will be calculated as the difference between the results obtained in steps 1 and 2 .

Table 39. Emission factors for a six-period contract in Spain

\begin{tabular}{clc}
\hline Period & \multicolumn{1}{c}{ Definition } & $\begin{array}{c}\text { Coefficient } \\
\text { tonCO2/MWh }\end{array}$ \\
\hline P1 & On-peak in high season & 0.750 \\
P2 & Shoulder in high season & 0.649 \\
P3 & On-peak in medium season & 0.750 \\
P4 & Shoulder in medium season & 0.649 \\
P5 & Shoulder in low season & 0.649 \\
P6 & Valley & 0.517 \\
\hline
\end{tabular}

Results of the total amount of $\mathrm{CO}_{2}$ emitted into the atmosphere before and after reducing energy in both balancing markets and secondary regulation are presented in Table 40. 
Table 40. Avoided emissions into the atmosphere for one customer

\begin{tabular}{|c|c|c|c|c|c|}
\hline \multirow{3}{*}{ Period } & \multirow{2}{*}{$\begin{array}{c}\text { Initial } \\
\text { Emissions }\end{array}$} & \multicolumn{2}{|c|}{ Balancing Markets } & \multicolumn{2}{|c|}{ Secondary Regulation } \\
\hline & & Final & Savings & Final & Savings \\
\hline & Ton $\mathrm{CO}_{2} /$ year & Ton $\mathrm{CO}_{2} /$ year & Ton $\mathrm{CO}_{2} /$ year & Ton $\mathrm{CO}_{2} /$ year & Ton $\mathrm{CO}_{2} /$ year \\
\hline P1 & 452.9 & 449.9 & 2.9 & 452.9 & - \\
\hline P2 & 542.1 & 534.9 & 7.2 & 541.7 & 0.4 \\
\hline P3 & 327.8 & 319.4 & 8.3 & 327.8 & - \\
\hline P4 & 473.4 & 445.0 & 28.4 & 472.6 & 0.8 \\
\hline P5 & 619.4 & 608.4 & 11.0 & 619.0 & 0.4 \\
\hline P6 & $2,447.0$ & $2,265.5$ & 181.4 & $2,315.5$ & 131.4 \\
\hline TOTAL & $4,862.5$ & $4,623.2$ & 239.4 & $4,729.4$ & 133.1 \\
\hline
\end{tabular}

\subsection{Conclusions of the Chapter}

This chapter demonstrates the high potential of customers from the meat products industry segment to provide the system with DR services in a profitable way for both the customer and the power system as a whole. The economic impact of meat industry customers participating in operation markets has been assessed, as well as the amount of avoided $\mathrm{CO}_{2}$ emissions into the atmosphere. The participation of a typical customer that produces meat products, whose technical potential was analyzed in Chapter 6, has been simulated in the framework of operation markets such as the balancing markets and secondary regulation in Spain, where the studied customer is located.

When the case of balancing markets was analyzed, savings of $6.2 \%$ in the annual electricity bill of the customer were obtained by applying the flexibility strategies evaluated in the Chapter 6 . If this potential is used for secondary regulation, savings of almost the $5 \%$ in the annual bill could be achieved.

The avoided cost arising from DR participation in these operation markets has also been evaluated, as the difference between the payment required by the customer and the cost of this service when it is provided by only generation resources. After estimating the potential of the whole segment by using tools developed in the Task XIII 
of the IEA, savings exceeded $6 \%$ for the whole power system. These results demonstrate the high potential in this segment, as individual customers can obtain appreciable benefits while also contributing to significant reductions in the total cost of power system management. 


\section{CHAPTER 8 : CONCLUSIONS}

The main conclusions arising from the work described in this dissertation are summarized in this final chapter, along with the relevance of the contributions achieved. After that, some specific areas where additional research would complement the present study will be highlighted.

\subsection{Conclusions and Contributions of the Dissertation}

The most relevant conclusion that can be drawn from the work described in this document is that customers' Demand Response potential has not been adequately considered in the design phase of existing DR programs, and therefore, many demand resources remain underexploited. Hence, the need for a new methodology to incorporate the demand side in the design stage of DR programs is apparent. This dissertation proves and justifies the fact that DR could be very profitable if customers were truly allowed and encouraged to participate, not only in energy markets and products, but also in specific electrical system operation mechanisms.

The main conclusions and contributions arising from this study are:

\subsubsection{Needs Identification: Underutilization of DRR and Requirement of New Tools}

Customers have traditionally provided the system with different demand side options in different parts of the world, but the presence of DR resources is not nearly as 
significant as the potential they actually have. Although customers are technically able to reduce their loads quickly and reliably, regulatory issues do not allow them to make the most of their possibilities; available DR programs are much too rigid. Customer participation in operation markets needs to be enhanced by means of new DR programs that exploit the whole potential of customers, and this dissertation provides both customers and regulators with suitable tools and methods to adequately evaluate and assess the technical and economical impact of such flexibility in the power system.

\subsubsection{Development of a New Methodology: Technical and Economic}

The methodology that has been developed, which constitutes the main contribution of this dissertation, is based on the evaluation and assessment of flexibility in decoupled processes, according to the way that energy is consumed in customer facilities. The methodology considers both the customer and the grid operator perspectives, which allows the optimal development of new DR programs focused on the improved operation of power systems.

The economic assessment included in the methodology is based on an avoided costs analysis, where the cost-benefit of customer participation in operation markets has been evaluated in addition to the avoided cost that the use of demand resources may have for the whole power system. Therefore, the methodology permits the assessment of the net benefit obtained by the customer, as well as the amount of money saved by the system when not only generation resources but also demand response resources are used.

\subsubsection{Validation of the Methodology: Application to the Food Industry}

In order to validate the methodology, it was applied to one energy-intensive sector, the food industry. After meticulously studying the processes performed in 
different segments from the food industry sector, ventilation and cooling (production and distribution) were identified as the most energy consuming processes. Indeed, cooling and ventilation represents more than $80 \%$ of total consumption of electricity according to the real tests performed on factories in the meat industry. Therefore, identifying the flexibility potential in this type of process was a priority. This represents a novel approach to flexibility in the sector, as customers have traditionally been unwilling to change any element or parameter of cooling and ventilation processes due to their sensitivity to the supply conditions and their direct relation to the quality of the final product.

Flexibility in the food industry was captured in two different strategies:

- In the cooling process, interruption of cooling production and distribution. Interruptions for up to two continuous hours are possible without causing any negative effect on this type of product.

- In ventilation, reduction of fan speed, compensated by the modification of the "on-off" sequences so that fans work for a longer time at a lower speed.

These two strategies have been technically evaluated and economically assessed, demonstrating their insignificant impact on the final product in addition to combined energy savings of up to $6 \%$ in the total daily energy consumption. Similarly, peak reductions of about $55 \%$ and $8 \%$ in the total load curve can be achieved by the implementation of both strategies.

\subsubsection{Use of Flexibility: Simulation of Customers Participation in Operation Markets in Spain}

The economic impact of meat industry customers participating in operation markets such as balancing markets and secondary regulation in Spain has been 
assessed, as well as the amount of avoided $\mathrm{CO}_{2}$ emissions into the atmosphere. A customer participating in balancing markets could achieve savings of up to $6.2 \%$ in the annual bill, whereas they could save about $5 \%$ for their participation in secondary regulation.

\subsubsection{Impact on the System: Extrapolation of Results to the Meat Industry Segment in Spain}

The avoided cost due to DR participation in operation markets has been determined as the difference between the payment required by the customer and the cost of this service when it is provided by only generation resources. A total flexible power potential of $411 \mathrm{MW}$ has been identified for the Spanish meat industry segment as a whole, which implies economic savings of more than $6 \%$ for the system. Thus, this segment has a demonstrably high flexibility potential which could bring substantial benefits to the power system.

\subsection{Future Research}

This dissertation opens the door to an innovative perspective on the evaluation of flexibility among customers which are traditionally considered rigid. It also provides a novel approach to the management of customer infrastructures in order to exploit their flexibility in electricity markets. Taking this study as a starting point, the following lines of research could be further developed in the future:

- Application of the methodology to other segments. Similar results to those obtained in the food industry could be achieved if other sectors are considered. Some of these sectors, such as the papermaking or the ceramic industry, have traditionally participated in existing DR programs as individual customers. Nevertheless, some research performed in the 
past has identified flexibility potential that currently remains underexploited.

- Evaluation of customer participation in operation markets in different countries. The Spanish case (specifically in the meat industry) has been analyzed in this dissertation, but the market rules are different when the regulatory framework changes, so the impact of flexibility could be assessed for each particular case.

- Definition of suitable DR programs for each segment according to their flexibility. The methodology allows regulators to design specific DR products in order to get the maximum profit for both the customer and the system. Therefore, new regulation should be developed in order to achieve this objective. 


\section{LIST OF REFERENCES}

[1] Klobasa, M.: "Analysis of demand response and wind integration in Germany's electricity market". IET Renewable Power Generation, Vol. 4, Iss. 1, pp. 55-63. June, 2009.

[2] Álvarez, C., Alcázar-Ortega, M., Escrivá, G, Gabaldón, A. "Technical and economical tools to assess customer demand response in the commercial sector". Elsevier Energy Conversion and Management, 50, pp. 2605-2612, July 2009

[3] Alcázar-Ortega, M., Escrivá-Escrivá, G., Álvarez-Bel, C. and Domijan, A.: "A case of improvement of efficiency in the meat industry: Speed variation of fans in drying chambers". Presented to the Elsevier Journal of Food Engineering, December 2010.

[4] Alcázar-Ortega, M., Escrivá-Escrivá, G., Álvarez-Bel, C. and Domijan, A.: "Evaluation and assessment of demand response potential: Application to the meat industry". Presented to Elsevier Energy Conversion and Management, July 2010.

[5] The birth of a EUropean Distributed EnErgy Energy Partnership that will help the large-scale implementation of distributed energy resources in Europe (EUDEEP), the European Project supported by the Sixth Framework programme for Research and Technological Development. Available online: http://www.eudeep.com

[6] Afonso, D., Pérez-Navarro, A., Encina, N., Álvarez, C., Rodríguez, J. and Alcázar-Ortega, M.: "Methodology for ranking of customer segments by their suitability for distributed energy resources applications", Elsevier Energy Conversion and Management, 48, pp. 1615-1623, January 2007

[7] Escrivá-Escrivá, G., Segura-Heras, I. and Manuel Alcázar-Ortega.: "Application of an energy management and control system to assess the potential of different control strategies in HVAC systems". Elsevier Energy and Buildings, 42, pp. 2258-2267, July 2010.

[8] Escrivá, G., Alcázar-Ortega, M., Álvarez, C.: "Integral Management System for the energy efficiency improvement in commercial facilities: Application to the Polytechnic University of Valencia". International Conference on Renewable Energies and Power Quality (ICREPQ'09). Valencia (Spain), April $15^{\text {th }}-17^{\text {th }}$ 2009. 
[9] Pérez Arriaga, J.I.: "Libro Blanco sobre la reforma del marco regulatorio de la generación eléctrica en España”. Ministerio de Industria, Turismo y Comercio. Madrid, June 2005

[10] Farinelli, U., Gusmerotti, M. "Evaluation of the Long-Term Evolution of Electricity Demand in the European Union". 26th USAEE/IAEE North American Conference, Ann Arbor 24-27 September 2006

[11] Red Eléctrica de España. Annual Report 2007, p. 18. Available online http://www.ree.es

[12] Markets Committee of the ISO/RTO Council: "Harnessing the Power of Demand. How ISOs and RTOs are integrating Demand Response into wholesale electricity markets". October, 2010. Available online: http://www.isorto.org

[13] Red Eléctrica de España. Annual Report 2009 (advance), p. 7. Available online: http://www.ree.es

[14] The Federal Energy Regulatory Commission Staff: "Draft for comment of the National Action Plan on Demand Response". March, 2010. Available online: http://www.ferc.gov

[15] Chiu, A., Ipakchi, A., Chuang, A., Qiu, B., Brooks, D., Koch, E., Zhou, J., Zientara, M.K., Precht, P.R., Burke, R., Crowder, R.S.: "Framework for Integrated Demand Response (DR) and Distributed Energy Resources (DER) Models". NAESB \& UCAlug. September, 2009. Available online: http://osgug.ucaiug.org/

[16] Albadi, M.H. and El-Saadany, E.F.: "A summary of demand response in electricity markets". Elsevier Power Systems Research 78, 2008, pp. 1989-1996

[17] Valero, S., Ortiz, M., Senabre, M., Álvarez, C., G-Franco, F. and Gabaldón, A.: "Methods for customer and demand response policies selection in new electricity markets". IET Gen. Transm. Distrib. 1, 2007, pp. 104-110.

[18] Energy Systems Integration - Demand Response. The California Energy Commission. Available online: http://www.energy.ca.gov

[19] Federal Energy Regulatory Commission: "State of the markets". Annual Report 2009. April, 2010.

[20] US Department of Energy. "Benefits of demand response in electricity markets and recommendations of achieving them". Report to the United States Congress, February 2006. Available online: http://eetd.Ibl.gov

[21] Newell, S., Hajos, A.: "Demand Response in the Midwest ISO: An Evaluation of Wholesale Market Design". The Brattle Group. January, 2010

[22] Energy Information Administration Glossary. Official Energy Statistics from the U.S. Available online: http://www.eia.doe.gov 
[23] Mickle C. "Energy Services and DSM in the Competitive Energy Supply Market". IEE, Savoy Place, London, 1994. 3p

[24] Torriti, J., Hassan, M.G. and Leach, M.: "Demand response experience in Europe: Policies, programmes and implementation". Elsevier Energy 35, 2010. pp. 1575-1583.

[25] Kirby, B.J.: "Demand response for power system reliability: FAQ". Oak Ridge Nat. Lab. December 2006.

[26] Goldman, C., Reid, M., Levy, R. and Silverstein, A.: "Coordination of energy efficiency and demand response". E.O. Lawrence Berkeley Nat. Lab. January 2010.

[27] International Energy Agency (IEA) Demand Response Resources - Task XIII. Available online: http://demandresponseresources.com

[28] Heffner, G.C.: "Configuring load as a resource for competitive electricity markets - review of demand response programs in the U.S. and around the world". Proceedings of the $14^{\text {th }}$ Annual Conference of the Electric Power Supply Industry (CEPSI 2002 Fukuoka). Available online: http://eetd.Ibl.gov

[29] Albadi, M.H. and El-Saadany, E.F.: "Demand response in electricity markets: an overview”. IEEE PES GM, Montreal, 2007, pp. 1-5

[30] Gellings, C., Chamberlin, J.: "Demand side management: Concepts and methods". PennWell Publishing Company. Tulsa (OK), US, 1993.

[31] Osborne, J., Warrier, D.: "A primer on demand response. The power grid: Evolving from a "dumb" network to a "smart" grid". Thomas Weisel Partners. October, 2007.

[32] Cappers, P., Goldman, C. and Kathan, D.: "Demand response in U.S. electricity markets: empirical evidence”. E.O. Lawrence Berkeley Nat. Lab. June 2009.

[33] Markets Committee of the ISO/RTO Council: "North American wholesale electricity demand response program comparison". April, 2009. Available online: http://www.isorto.org

[34] Southwest Power Pool. "2009 Annual Report". Southwest Power Pool, Inc. Available online: http://www.spp.org

[35] NYISO Auxiliary Market Operations: "Demand Response Service Providers". New York Independent System Operator. July, 2010. Available online: http://www.nyso.com

[36] NYISO Auxiliary Market Operations: "Emergency demand response program manual". New York Independent System Operator. June, 2010. Available online: http://www.nyso.com 
[37] NYISO Auxiliary Market Operations: "Demand response premier". New York Independent System Operator. May, 2005. Available online: http://www.nyso.com

[38] NYISO Auxiliary Market Operations: "Installed capacity manual". New York Independent System Operator. June, 2010. Available online: http://www.nyso.com

[39] NYISO Auxiliary Market Operations: "Day-ahead demand response program manual ". New York Independent System Operator. July, 2003. Available online: http://www.nyso.com

[40] Douglass, J., Shafferman, H.: "Technical feasibility and value to the market of smaller demand response resources providing ancillary services". ISO New England Inc. October, 2009. http//:www.iso-ne.com

[41] ISO New England Manual for Measurement and Verification of Demand Reduction Value from Demand Resources. ISO New England Inc. June, 2010. Available online: http//:www.iso-ne.com

[42] ISO New England ISO New England. "2009 annual markets report". ISO New England Inc. May, 2010. Available online: http://www.iso-ne.com

[43] Yoshimura, $\mathrm{H}$.: "New England Demand Response Resources: Present observations and future challenges". Demand resources Department. ISO New England, Inc. February, 2008. Available online: http://www.narucmeetings.org/

[44] FERC Electric Tariff No. 3. Section III: Market Rule 1, Standard Market Design. Appendix E: Load Response Program. ISO New England Inc. February, 2005. http//:www.iso-ne.com

[45] "Frequently Asked Questions (FAQ) regarding the Real-Time Price Response Program (RT-Price)". ISO New England Inc. July, 2005. Available online: http//:www.iso-ne.com

[46] ISO New England Manual for the Real-Time Price Response and Day-Ahead Load Response Programs. ISO New England Inc. June, 2010

[47] "Frequently Asked Questions (FAQ) regarding the Day-Ahead Load Response Program (DALRP)". ISO New England Inc. July, 2005. Available online: http//:www.iso-ne.com

[48] ISO New England ISO New England. Manual for the Forward Capacity Market (FCM). ISO New England Inc. June, 2010. Available online: http//:www.isone.com

[49] "Demand Response and the Forward Capacity Market (FCM)". Online resource available at the Official Website of the Commonwealth of Massachusetts. http://www.mass.gov

[50] FERC Electric Tariff No. 3. Section III: Market Rule 1, Standard Market Design. Chapter XIII ISO New England Inc. February, 2007. http//:www.iso-ne.com 
[51] PJM Interconnection. "PJM Demand Response fact sheet: a summary of demand response in PJM". PJM Interconnection, L.L.C. May, 2008. Available online: http://www.pjm.org

[52] PJM Interconnection. "PJM Manual 28: Operating Agreement Accounting". PJM Interconnection, L.L.C. June, 2010. Available online: http://www.pim.com

[53] Demand-Side Working Group of the ERCOT Wholesale Market Subcommittee: "Load participation in the ERCOT market: Financial opportunities for reducing electricity load". ERCOT, Inc. May, 2006. Available online: http://www.ercot.com

[54] Huang, S.H., Dumas, J., González-Pérez, C., Lee, W.J.: "Grid security through load reduction in the ERCOT Market". IEEE Trans. on Industry Applications, vol. 45, n. 2, pp. 555-559. March-April 2009.

[55] Electric Reliability Council of Texas. "Emergency Interruptible Load Service: Overview". ERCOT, Inc. July, 2009. Available online: http://www.ercot.com

[56] Wang, H., Cai, J., Lee, W.: "Load participation in the ERCOT market". Proceedings of the $37^{\text {th }}$ Annual North American Power Symposium, pp.509-515. October 2005.

[57] Bharvirkar, R., Heffner, G., Goldman, C.: "Retail Demand Response in Southwest Power Pool”. E.O. Lawrence Berkeley Nat. Lab. January 2010.

[58] Starnes, H.: "Status of SPP activities relating to FERC Order 719". Presentation for APSC. Southwest Power Pool. June, 2010. Available online: http://www.spp.org

[59] Doying, R.: "Demand Response in Organized Markets". Technical Conference on Competition in Wholesale Markets. May, 2007.

[60] Bharvirkar, R., Goldman, C., Heffner, G., Sedano, R.: "Coordination of retail demand response with Midwest ISO wholesale markets". E.O. Lawrence Berkeley Nat. Lab. May, 2008.

[61] California ISO: "Demand Response - Frequently Asked Questions". California Independent System Operator. January, 2010. Available online: http://www.caiso.com

[62] California ISO: "Participating Load Technical Standard". California Independent System Operator. February, 2007. Available online: http://www.caiso.com

[63] California ISO: "Process for Participating Load Program". California Independent System Operator. February, 2007. Available online: http://www.caiso.com

[64] Salt River Project Power and Water: "SRP supporting cleaner power and energy efficiency”. Technical brochure. SPR, 2010. Available online: http://www.spr.com

[65] Salt River Project Power and water: "SRP PowerPartner ${ }^{\mathrm{TM}}$ Demand Response Program". SPR, 2010. Available online: http://www.enernoc.com 
[66] European Commision: "Quarterly Report on European Electricity Markets - 2010 $1^{\text {st }}$ Quaterly: January 2010 - March 2010". Market observatory for energy, vol. 3, issue 1. Available online: http://ec.europa.eu/energy

[67] Everis \& Mercados EMI: "From regional markets to a single European market. Final report”. April, 2010. Available online: http://ec.europa.eu/energy

[68] Trevino, L.: "Liberalization of the Electricity Market in Europe: An overview of the electricity technology and the market place". College of Management of Technology. Federal Polytechnic School of Lausanne. January, 2008.

[69] Chardon, A., Almén, O., Lewis, P.E., Stromback, J., Château, B.: "Demand Response: A decisive breakthrough for Europe". Capgemini Consulting, 2008.

[70] European Transmission System Operators: "Demand Response as a resource for the adequacy and operational reliability of the power systems". 12 January 2007. Available online: http://www.entsoe.eu

[71] Ng'uni, A. and Tuan, L.A.: "Interruptible load and demand response: Worldwide picture and the Situation in Sweden. IEEE $38^{\text {th }}$ Annual North American Power Symposium. Carbondale, IL (USA), $17^{\text {th }}-19^{\text {th }}$ September 2006.

[72] Andersen, F.M., Jensen, S.G., Larsen, H.V., Meibom, P., Ravn, H., Skytte, K. and Togeby, M.: "Analyses of Demand Response in Denmark". Riso National Laboratory. Ea Energy Analyses. October, 2006.

[73] Statnett (The Norwegian System Operator): "Tariff brochure 2010". Available online: http://www.statnett.no/no/Kraftsystemet/Tariffer-og-avtaler

[74] Hathaway, G.: "Demand Side Opportunities". Nationalgrid UK. July $9^{\text {th }} 2009$. Available online: http://www.nationalgrid.com/uk

[75] Schneider Electric: "Services \& projects: Demand Response Programme". Technical brochure 2010. Available online: http://www.schneider-electric.co.uk/

[76] Terna (The Italian TSO): "Grid Code: The code for transmission, dispatching, developing and security of the grid". Chapter 4. November 2005. Available online: http://www.terna.it

[77] Comisión Nacional de la Energía. Informe de caracterización de clientes eléctricos nacionales acogidos a la Tarifa Horaria de Potencia en 2004 October 2005. Available Online: http://www.cne.es

[78] Bourgain, $\mathrm{G}$ (coord.) et al.: "Integrating distributed energy resources into today's electrical system". ExpandDER, June 2009

[79] Encinas Redondo, N.: "Metodología de diseño y evaluación de productos de respuesta de la demanda en mercados eléctricos competitivos". Ph.D. Dissertation. Valencia, April 2009. Polytechnic University of Valencia, Spain. 
[80] Braun, J.E., Mercer, K.: "VSAT - Ventilation Strategy Assessment Tool". California Energy Commission. August, 2003. Available online: http://www.archenergy.com

[81] Alcázar-Ortega, M., Escrivá-Escrivá, G., Valencia-Salazar, I., Álvarez Bel, C., Alfonso Solar, D. "Validation of a methodology to assess customer demand response: application to the commercial sector". IEEE/PES - IAS Conference on Sustainable Alternative Energy. Valencia, Spain, September 28-30, 2009.

[82] Alcázar-Ortega, M. Escrivá-Escrivá, G., Segura-Heras, I.: "Methodology for validating technical tools to assess customer Demand Response: Application to a commercial customer". Elsevier Energy Conversion and Management, vol. 52, issue 2, pp. 1507-1511, February 2011.

[83] Farahani, M.E.S., Saeidi, N. "Case study of design and implementation of a thermal energy storage system". First International Power and Energy Conference PECon. Putrajaya, Malaysia, November 28-29, 2006.

[84] Escrivá-Escrivá, G.: "Nuevas herramientas para facilitar la respuesta activa de consumidores en mercados eléctricos liberalizados: Implementación y retribución". Ph.D. Dissertation. Valencia, April 2009. Polytechnic University of Valencia, Spain.

[85] Escrivá, G., Alcázar-Ortega, M., Álvarez, C. "Integral management system for the energy efficiency improvement in commercial facilities: Application to the Polytechnic University of Valencia". International Conference on Renewable Energies and Power Quality (ICREPQ'09), Valencia, Spain, April 15-17, 2009

[86] Red Eléctrica de España, S.A.: "Emisiones de $\mathrm{CO}_{2}$ producidas en el sistema eléctrico en tiempo real". REE, S.A., June 2009.

[87] AICIA: "Condiciones de aceptación de procedimientos alternativos a LIDER y CALENER". Instituto para la Diversificación y Ahorro de la Energía (IDAE) y Ministerio de la Vivienda. Madrid, May 2009.

[88] Tractebel Engineering Suez: "Study on interaction and dependencies of balancing markets, intraday trade and automatically activated reserves". SuezTractebel, S.A., final report, February 2009. Available online: http://www.tractebel-engineering.com

[89] Lobato-Miguélez, E., Egido-Cortés, I., Rouco-Rodríguez, L. and López-Camino, G.: "An overview of ancillary services in Spain". Elsevier Electric Power Systems Research, Volume 78, Issue 3, pp. 515-523, March 2008

[90] Raineri, R., Ríos, S. and Schiele, D.: "Technical and economic aspects of ancillary services markets in the electric power industry: and international comparison". Elsevier Energy Policy, Volume 34, issue 13, pp. 1540-1555, September 2006. 
[91] Rebours, Y., Kirschen, D. and Trotignon, M.: "Fundamental design issues in market for ancillary services". Elsevier, the Electricity Journal, Volume 20, Issue 6, pp. 26-34. July 2007.

[92] Hirst, E. and Kirbi, B.: "Cost for electric power ancillary services". Elsevier, the Electricity Journal, Volume 9, Issue 10, pp. 26-30, December 1996.

[93] Kristiansen, T.: "The Nordic approach to market-based provision of ancillary services”. Elsevier Energy Policy, Volume 35, Issue 7, pp. 3681-3700, July 2007.

[94] Jansen, J.J., Van der Welle, A.J., Joode, J.: "The evolving role of the DSO in efficiently accommodating distributed generation”. Energy Research Centre of the Netherlands. June, 2007.

[95] NGC: "An Introduction to Standing Reserve". National Grid Company, Market development report, August 2001, available online: http://www.nationalgrid.com

[96] Shudakara Reddy, B.: "Economic evaluation of demand-side management options using utility avoided costs". Elsevier Energy, Volume 21, Issue 6, Pages 473-482, June 1996.

[97] RAE:"The cost of generating electricity". Study carried out by BP Power for the Royal Academy of Engineering. London, March 2004. Available online: http://www.raeng.org.uk

[98] Khatib, H.: "Review of OECD study into "Projected costs of generating electricity - 2010 edition”. Elsevier Energy Policy, Volume 38, Issue 10, Pages 5403-5408, October 2010.

[99] DOE Energy Information Administration: "2016 Levelized Cost of New Generation Resources". Annual Energy Outlook 2010, December 2009, DOE/EIA-0383(2009). Available online: http://www.eia.doe.gov

[100] Center for Industrial Research and Service (CIRAS): "Energy-Related Best Practices: A sourcebook for the food industry". lowa State University. Ames IA, 2005

[101] Berk, Z.: "Food process engineering and technology". Elsevier Inc. Food Process Engineering and Technology, Academic Press, ISBN: 978-0-12-373660-4. San Diego, 2009. Available online: http://www.sciencedirect.com

[102] The United States Meat Industry. American Meat Institute AMI. March 2009 Report. Available online: http://www.meatami.com

[103] FAOSTAT. Food and Agriculture Organization of the United Nations. Annual Statistical Report, 2005. Available online: http://faostat.fao.org, accessed on February 2009.

[104] Norup, J.: "Improving Industrial Energy Efficiency in the food industry". 2007 Growing the Margins Energy Conference. London (ON, Canada) April, $12^{\text {th }}-13^{\text {th }}$ 2007. Available online: http://www.gtmconference.ca 
[105] Ramírez, C.A., Patel, M., Blok, K. "How much energy to process one pound of meat? A comparison of energy use and specific energy consumption in the meat industry for European countries". Elsevier Energy, 31, pp. 2047-2063, September 2006

[106] Comaposada, J.: "The Sorption Isotherms and Water Diffusitivity in Muscles of Pork Ham at Different $\mathrm{NaCl}$ Contents". Ph.D. Dissertation, Dept. of Thermal Engines and Machines. Univ. Polyt. Cataluña. 1999

[107] Arnau J., Gou P., Comaposada J.: "Effect of the relative humidity of drying air during the resting period on the composition and appearance of dry-cured ham surface". Elsevier Meat Science, 65 (4), pp. 1275-1280. January, 2003.

[108] Ventanas, J.: "Tecnología del jamón ibérico". Ed. Mundi-Prensa, Madrid, 2001. ISBN 8471149443.

[109] ASHRAE: "Psychrometrics - SI Units Edition" in Fundamentals Handbook Ed. American Society of Heating, Refrigerating and Air-Conditioning Engineers, 2005. Chapter 6, pp. 6.1-6.17.

[110] Naughton, P., Wang, R.D., Filipovic, A., Hundt, A. and Cooper, D.W.: "High efficiency particulate air (HEPA) filter velocity reduction study". International SEMATECH manufacturing Initiative (ISMI). August, 2006. Available online: http://www.ismi.sematech.org

[111] Álvarez-Bel, C., Gabaldón-Marín, A., Valencia-Salazar, I., Alcázar-Ortega, M. and Escrivá-Escrivá, G.: "Market Integration of Responsive Customers: Application to Energy and Balancing Markets". International Journal of Power and Energy Systems Design, 29, pp. 48-56, 2009.

[112] Alcázar-Ortega, M., Álvarez-Bel, C., Domijan, A., Escrivá-Escrivá, G.: "Economical and environmental evaluation of flexibility of meat industry customers participating in operation markets". Presented to Elsevier Applied Energy, December 2010. 
APPENDICES 


\section{Appendix A: Abbreviations}

\begin{tabular}{|c|c|}
\hline AC & Air Conditioning \\
\hline AIU & Ameren Illinois Utilities \\
\hline APS & Arizona Public Service Company \\
\hline BETTA & British Electricity Trading and Transmission Arrangements \\
\hline BUL & Balancing Up Load \\
\hline CAISO & California Independent System Operator \\
\hline $\operatorname{cCS}$ & Carbon Capture and Storage \\
\hline CIP & Cleaning in place \\
\hline CDR & Commercial Demand Reduction Program \\
\hline CLP & Connecticut Light and Power \\
\hline CNE & Comisión Nacional de la Energía \\
\hline ComEd & Commonwealth Edison \\
\hline CPP & Critical Peak Pricing \\
\hline DADRP & Day-Ahead Demand Response Program \\
\hline DALRP & Day-Ahead Load Response Program \\
\hline DEC-1 & Daily Energy Credit Rider Schedule \\
\hline DER & Distributed Energy Resources \\
\hline DR & Demand Response \\
\hline DRR & Demand Response Resources \\
\hline DRR-Pilot & Demand Response Reserves Pilot \\
\hline DROP & Demand Response Opportunity Pilot \\
\hline DSM & Demand Side Management \\
\hline DSASP & Demand Side Ancillary Services Program \\
\hline EBP & Economic Based Programs \\
\hline
\end{tabular}




\section{Appendix A (continued)}

\begin{tabular}{|c|c|}
\hline ED-CPP & Extreme Day Critical Peak Pricing \\
\hline EDF & Électricité de France \\
\hline EDP & Extreme Day Pricing \\
\hline EDRP & Emergency Demand Response Program \\
\hline EILS & Emergency Interruptible Load Service \\
\hline EIS & Energy Imbalance Service \\
\hline ERCOT & Electric Reliability Council of Texas \\
\hline EU & European Union \\
\hline EU-DEEP & European Distributed Energy Partnership \\
\hline FCM & Forward Capacity Market \\
\hline FERC & Federal Energy Regulatory Commission \\
\hline FLP & Florida Light and Power Company \\
\hline FR & Fast Reserve \\
\hline HVAC & Heating, Ventilation \& Air Conditioning \\
\hline IAC & Interruptible Air Conditioning \\
\hline IBP & Incentive Based Programs \\
\hline IEA & International Energy Agency \\
\hline IIE-UPV & $\begin{array}{l}\text { Institute for Energy Engineering of the Polytechnic University of } \\
\text { Valencia }\end{array}$ \\
\hline IMS & Integral Management System \\
\hline ISO & Independent System Operator \\
\hline ISO-NE & Independent System Operator-New England \\
\hline LaaR & Loads acting as a Resource \\
\hline LSE & Load Serving Entity \\
\hline
\end{tabular}




\section{Appendix A (continued)}

\begin{tabular}{|c|c|}
\hline MIBEL & Iberian Electricity Market \\
\hline MISO & Midwest Independent Transmission System Operator \\
\hline NACE & National Classification of Economic Activities \\
\hline NAICS & North American Industry Classification System \\
\hline NEPOOL & New England Power Pool \\
\hline LaaR-NSRS & Loads acting as a Resource-Non-Spinning Reserve Service \\
\hline NYISO & New York Independent System Operator \\
\hline ODR & Other Demand Resources \\
\hline O\&M & Operating and Maintenance \\
\hline OP & Operation programs \\
\hline PCUE & $\begin{array}{l}\text { Power Center for Utility Explorations of the University of South } \\
\text { Florida }\end{array}$ \\
\hline Pepco & Potomac Electric Power Company \\
\hline PE & Progress Energy \\
\hline PBP & Price-Based Programme \\
\hline PGE & Pacific Gas \& Energy \\
\hline PJM & Pennsylvania-Jersey-Maryland \\
\hline QSE & Qualified Scheduling Entity \\
\hline REE & Red Eléctrica de España, S.A. \\
\hline RRS & Responsive Reserve Service \\
\hline RTO & Regional Transmission Operators \\
\hline RTDR & Real-Time Demand Response Programs \\
\hline RTEGR & Real Time Emergency Generation Resource \\
\hline RTP & Real Time Pricing \\
\hline
\end{tabular}




\section{Appendix A (continued)}

$\begin{array}{ll}\text { RT-Price } & \text { Real-Time Price } \\ \text { SCE } & \text { Southern California Edison } \\ \text { SCR } & \text { Special Case Resource } \\ \text { SDGE } & \text { San Diego Gas \& Electric } \\ \text { SK } & \text { Svenska Kraftnät } \\ \text { SO } & \text { System Operator } \\ \text { SPP } & \text { Southwest Power Pool } \\ \text { SPR } & \text { Salt River Project Power and Water } \\ \text { TECO } & \text { Tampa Electric Company } \\ \text { TOU } & \text { Time of use } \\ \text { THP } & \text { Hourly power tariff } \\ \text { TSO } & \text { Transmission System Operators } \\ \text { VDDR } & \text { Variable Dispatch Demand Response Program } \\ \text { UCTE } & \text { Union for the Co-ordination of Transmission of Electricity }\end{array}$




\begin{abstract}
ABOUT THE AUTHOR
Manuel Alcázar-Ortega was born in Chinchilla, Spain. He received degrees in technical industrial engineering from the University of Castilla-La Mancha (UCLM) in 2001 and in electrical engineering from the Polytechnic University of Valencia (UPV) in 2004. Since then, he has been working for the Institute for Energy Engineering at UPV, where he has worked on R\&D projects in cooperation with the Spanish TSO (REE), large and medium customers, and different utilities. In the framework of the dual Ph.D. program in Electrical Engineering between the UPV and the USF, he worked for six months at the Power Center for Utility Explorations (PCUE) of the University of South Florida in 2008. His main research fields are focused on electricity customer profiling and the active participation of demand in electricity markets.
\end{abstract}

